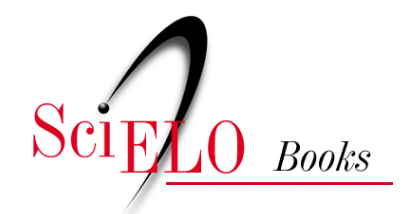

\title{
Reflexões e práticas na formação de educadores
}

\author{
Cesar de David \\ Janete Webler Cancelier \\ (orgs.)
}

DAVID, C., and CANCELIER, J.W., eds. Reflexões e práticas na formação de educadores [online]. Rio de Janeiro: EdUERJ, 2018, 379 p. ISBN 978-85-7511-475-9.

https://doi.org/10.7476/9788575114759.

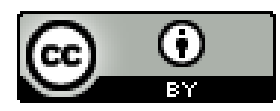

All the contents of this work, except where otherwise noted, is licensed under a Creative Commons Attribution 4.0 International license.

Todo o conteúdo deste trabalho, exceto quando houver ressalva, é publicado sob a licença Creative Commons Atribição $\underline{4.0}$.

Todo el contenido de esta obra, excepto donde se indique lo contrario, está bajo licencia de la licencia $\underline{\text { Creative Commons }}$ Reconocimento 4.0. 
Reflexões e práticas

na formação de educadores 


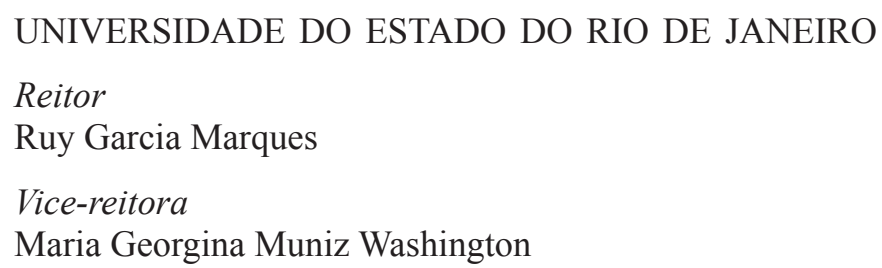

EDITORA DA UNIVERSIDADE DO ESTADO DO RIO DE JANEIRO

\section{Conselho Editorial}

Glaucio José Marafon (presidente)

Henriqueta do Coutto Prado Valladares

Hilda Maria Montes Ribeiro de Souza

Italo Moriconi Junior

José Ricardo Ferreira Cunha

Lucia Maria Bastos Pereira das Neves

Luciano Rodrigues Ornelas de Lima

Maria Cristina Cardoso Ribas

Tania Maria Tavares Bessone da Cruz Ferreira

Anibal Francisco Alves Bragança (EDUFF)

Katia Regina Cervantes Dias (UFRJ) 
CESAR DE DAVID

JANETE WEBLER CANCELIER

(Organização)

\section{Reflexões e práticas na formação de educadores}

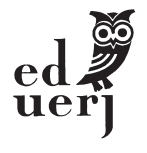

Rio de Janeiro 2018 
Copyright (c) 2018.

Todos os direitos desta edição reservados à Editora da Universidade do Estado do Rio de Janeiro. É proibida a duplicação ou reprodução deste volume, ou de parte do mesmo, em quaisquer meios, sem autorização expressa da editora.

\begin{tabular}{|c|c|}
\hline \multicolumn{2}{|c|}{$\begin{array}{l}\text { Editora da UNIVERSIDADE DO ESTADO DO } \\
\text { Rua São Francisco Xavier, } 524 \text { - Maracanã } \\
\text { CEP 20550-013 - Rio de Janeiro - RJ - Brasil } \\
\text { Tel./Fax.: } 55 \text { (21) 2334-0720 / 2334-0721 } \\
\text { www.eduerj.uerj.br } \\
\text { eduerj@uerj.br }\end{array}$} \\
\hline Editor Executivo & Glaucio Marafon \\
\hline Coordenadora Administrativa & Elisete Cantuária \\
\hline Coordenadora Editorial & Silvia Nóbrega \\
\hline Assistente Editorial & Thiago Braz \\
\hline Coordenador de Produção & Mauro Siqueira \\
\hline Supervisor de Revisão & Elmar Aquino \\
\hline Revisão & $\begin{array}{l}\text { Erika Neuschwang } \\
\text { Iuri Pavan }\end{array}$ \\
\hline Capa & Thiago Netto \\
\hline Projeto Gráfico e Diagramação & Editora Morandi \\
\hline
\end{tabular}

CATALOGAÇ̃̃O NA FONTE UERJ/REDE SIRIUS/NPROTEC

R332 Reflexões e práticas na formação de educadores / Cesar de David, Janete Webler Cancelier, organização. - Rio de Janeiro : EdUERJ, 2018. $384 \mathrm{p}$.

ISBN 978-85-7511-475-9

1. Professores - Formação. 2. Educadores. I. David, Cesar de. II. Cancelier, Janete Webler.

CDU 37.011.3-051 


\section{SUMÁRIO}

Apresentação

PARTE I - FORMAÇÃO INICIAL DE PROFESSORES

CAPÍTULO 1. Formação de professores-educadores do campo

Luis Pedro Hillesheim

CAPÍTULO 2. Experiências de um grupo de pesquisa na formação

de professores: o GPET-UFSM

Cesar De David e Janete Webler Cancelier

CAPÍTULO 3. Aprendizagem cooperativa no ensino superior:

uma discussão pertinente

Marinez Cargnin-Stieler e Marcus Vinicius Araújo Damasceno

CAPÍTULO 4. Educação escolar quilombola: os educadores do território quilombola Vão Grande

Francisca Edilza B. A. Carvalho e Maria Helena Tavares Dias

CAPÍTULO 5. Financiamento da educação básica no Brasil:

uma discussão necessária

Andréia da Silva Mafassioli

CAPÍTULO 6. Algumas reflexões sobre educação especial

Gabriela Dambrós e Solange de Moura Trindade

CAPÍTULO 7. Educação como ferramenta de preservação do

patrimônio cultural brasileiro.

Luciana de Aguilar Belizio e Idiane Manica Radaelli 
CAPÍTULO 8. A teoria e a prática na formação de professores de

Geografia na modalidade semipresencial

Anercilia Martins, Glaucio José Marafon e Vanilda Teófilo

CAPÍTULO 9. Projeto Parceladas e formação de professores na UNEMAT

Maria Auxiliadora de Azevedo Coutinho e Castro e José Amilcar Bertholini de Castro

\section{PARTE II - FORMAÇÃO DOS EDUCADORES DO CAMPO}

CAPÍTULO 10. Trajetórias pelo PIBID Interdisciplinar Educação do Campo: atuação em uma escola no campo.

Ivanio Folmer e Ane Carine Meurer

CAPÍTULO 11. Trabalho e educação: a qualificação de agricultores familiares por meio do Pronatec Campo 165

Zenicleia Angelita Deggerone e Douglas Cenci

CAPÍTULO 12. Pedagogia da alternância: educador/monitor e práticas pedagógicas

Cintia Moralles Camillo e Liziany Müller Medeiros

CAPÍTULO 13. A formação de professores na educação quilombola e seus desafios contemporâneos

Dilmar Luiz Lopes e Claudete dos Santos da Silva

CAPÍTULO 14. A luta por educação do campo no Colégio Estadual

do Reassentamento São Marcos - município de Catanduvas/PR

Edimar Rodrigo Rossetto e Marli Terezinha Szumilo Schlosser

PARTE III - FORMAÇÃO CONTINUADA DE PROFESSORES

CAPÍTULO 15. Escola rural e formação cidadã: experiência do Projeto

Arquitetos do Saber em Cachoeira do Sul/RS.

Daiane Loreto de Vargas, Janete Webler Cancelier e Tatiane Almeida Netto

CAPÍTULO 16. O ensino de História e a formação continuada de docentes

da educação básica

Dante Luis Vartha e Diovane Dill

CAPÍTULO 17. Formação continuada de professores indígenas

Hellen Cristina de Souza e Eliane Boroponepá Monzilar 
CAPÍTULO 18. Formação de professores de História no exercício da docência: o caso do PROFHIST 275

José Iran Ribeiro e Leonice Alves Pereira Mourad

CAPÍTULO 19. Formação colaborativa na universidade: possibilidades formativas para mudanças pedagógicas

Mariane D. Martins

CAPÍTULO 20. Especialização em agricultura familiar camponesa e educação do campo: a experiência do Residência Agrária na UFSM/RS 307

Carmen Rejane Flores Wizniewsky e Maiquel Ivan Rossato

CAPÍTULO 21. Ideologia hegemônica em questão: o rural brasileiro representado em livros didáticos do Programa Nacional do Livro Didático (PNLD - Campo)

Lair Miguel da Silva e Marcelo Cervo Chelotti

CAPÍTULO 22. Como viver junto: um estado iminente dos dispositivos de arte na atualidade e seu ensino

Rogerio Vanderlei de Lima Trindade

CAPÍTULO 23. Formação de professores de geografia: trajetórias e desafios do Programa Institucional de Bolsa de Iniciação à Docência (PIBID) 357 Gilda Maria Cabral Benaduce e Lisane Regina Vidal Conceição

Sobre os autores. 


\section{APRESENTAÇÃO}

A obra Reflexões e práticas na formação de educadores é uma publicação elaborada pelas mãos e pelas ideias de professores e professoras do Ensino Superior e da Educação Básica, educadores e educadoras em serviço e em formação, todos e todas articulados/as ao tema da formação dos/as educadores/as brasileiros/as. Os escritos aqui reunidos são reflexões e relatos sobre práticas e experiências desenvolvidas em escolas, universidades e outros ambientes educativos. Por essa razão, as experiências formativas são diversificadas e dinâmicas, decorrentes das políticas públicas de abrangência nacional e das iniciativas institucionais em âmbito local e regional. Essa iniciativa decorre da identificação de uma lacuna na sistematização e reflexão que envolve a temática da formação dos educadores, com especial ênfase na diversidade presente no cenário nacional, visto que inúmeras experiências formativas são ricas em especificidades que precisam ser socializadas.

Nesse sentido, nosso propósito foi estabelecer um profícuo diálogo com os estudiosos da área da Educação ocupados com a formação de professores e professoras, de tal sorte a contribuir com os debates nessa área do conhecimento a partir dos sujeitos que estão diretamente envolvidos com ela, qualificando sobremaneira o diálogo entre a universidade e a escola.

Na primeira parte da coletânea, são apresentadas nos capítulos, de forma diversificada, discussões acerca da formação inicial de professores. O foco são os cursos de licenciatura, buscando problematizar/socializar experiências na formação de professores no espaço universitário, a partir dos problemas e possibilidades colocados pelos programas e projetos voltados aos educadores em formação.

Na segunda parte, as contribuições se relacionam à formação dos educadores do campo. São perspectivas abrangentes que apresentam experiências 
de formação de professores/as para a docência no espaço rural, enfatizando as modalidades de educação do campo, educação quilombola e educação escolar indígena.

$\mathrm{Na}$ terceira e última parte, os escritos discutem a formação continuada de professores e professoras a partir de experiências e reflexóes de jovens egressos e trabalhadores/as experientes, articulados com temas sensíveis para a prática profissional, como é o caso do livro didático, de programas como o PIBID ou dos mestrados profissionais, que demandam alunos com comprovado exercício da docência. 
PARTE I

FORMAÇÃO INICIAL DE PROFESSORES 


\section{Formação de professores-educadores do campo}

Luis Pedro Hillesheim

\section{Contexto de uma educação rejeitada}

Por culpa das famílias, educadores, professores, monitores, educandos, escolas, associações de famílias, universidades, secretarias de educação, agricultura, enfim, organizações sociais de ordem pública e privada, a educação do campo está proibida. Minha convicção é de que somos culpados, por não reagirmos às reais necessidades dos que trabalham no campo, mas como reagir se a prática do discurso de mais produção e menos educação corrompe tudo e todos?

A educação do campo deixa de existir quando: a) não escutamos ninguém, não entendemos a realidade dos envolvidos no processo de educação do campo; simplesmente virando os olhos para o lado, não vemos, fingimos não ver, ficamos míopes, cegos para o que precisa ser visto; b) possuímos uma enorme ausência de trajeto, nossas metas são confusas, nossos olhares não focam, andamos sem saber o caminho e sem ter noção de para onde caminhar; c) temos e vemos enormes desafios ao experimentar novas ideias, novos caminhos, novas formas de construir a sociedade, a educação do campo. Permanecemos demasiadamente distantes desses elementos apontados e que fragilizam a educação do campo. Mas por que não escutamos? Por que não possuímos um foco? Por que novas ideias não são aceitas?

Precisamos pensar na educação a partir da sua origem, no momento em que ela consistia na ideia de momentos de estudo e debates, espaços de reflexão. Quando obrigatória, era para escravos e caracterizava sofrimento, imposição. No século XVIII, tem-se o conceito de educação pública gratuita obrigatória, no sentido de obediência e docilidade, que passa a ser internacionalizada com o objetivo de igualdade de classes sociais; mais tarde, a educação passa a seguir o modelo de divisão de classes, tornando-se elitista. 
Na França, no período do império de Napoleão (1804-15), surgem as primeiras experiências de ensino com corpo docente, séries escolares, conteúdos determinados por alguém, um docente por ano, por disciplina, por turma (Cambi, 1999). Uma resposta ideal para formar trabalhadores diante de um modelo industrial, para o qual os alunos deveriam seguir regras, ser conduzidos, em seus estudos, por um mestre que os ensinaria a desenvolver uma cultura de reprodução de conhecimento, fruto de um sistema de produção em que todos devem aprender o mesmo.

Substituímos esse modelo de educação que prepara as pessoas para reproduzir um sistema de produção, consumo e que ameaça o sistema hegemônico? Temos uma escola fechada para o mundo exterior, que ensina "verdades" pensadas por alguém, e não pelos territórios criados tendo em vista as necessidades das pessoas.

Para sabermos se a educação de hoje avançou no sentido da formação de professores-educadores e da valorização do ser humano, precisamos responder a algumas questôes:

a. Conhecer os alunos: as escolas, as universidades e os professores-educadores conhecem os alunos? Conseguimos viver sem saber logaritmo, mas não sem se relacionar com as pessoas. Que ambientes estamos oferecendo para que os adultos pensem diferente em nossas universidades? A escola é uma espécie de programação linear, aprende e repete, mas como isso é possível se somos diferentes?

b. Respeitar o pensar das pessoas: por que precisamos e/ou insistimos em interferir no processo de constituição de um ser humano, incluir o aluno na cultura e não deixar fluir a cultura do aluno? Ele precisa estudar, ter uma profissão a fim de ser alguém na vida, ir à escola como se ainda não fosse ninguém e lá se constituir ser humano. Dessa forma, estamos cuidando e respeitando os anseios dos alunos?

c. Desenvolver a autonomia: dividimos as ciências, separamos tudo em conteúdos e queremos formar sujeitos integrais. Seria, então, a educação apenas o transmitir de conhecimentos estabelecidos por outros? E caberia aos alunos a simples reprodução de aprendizagens, com disciplina e comportamento mecânicos. 
Quando parte de mecanismos de controle ou qualquer forma de imposição, a própria educação não é ética consigo. Se deixa de ser natural, passa a existir um aprendizado por ameaça, e a diversidade, que é a riqueza da sociedade, desaparece.

Uma escola que decide pelos seus alunos nunca vai deixá-los serem o que são e o que desejam ser, e estes nunca serão capazes de decidir pelos próprios atos, pois não desenvolveram a autonomia. Sem ter sido estimulado a ser autônomo, o alunoterá mais dificuldade em estabelecer um projeto profissional e, por consequência, de vida.

Qual o conceito de educação que temos reproduzido? Chegamos ao cúmulo de diferenciar educação formal de educação informal. Qual a efetiva diferença, se é que se pode estabelecê-la? E mais, isso faria a diferença na vida prática do aluno? Precisamos primeiro reconhecer que educação é reconhecer-se, é ter amor, é comunicar-se, é desenvolver as capacidades humanas, é deixar o aluno aprender porque quer aprender. Em uma verdadeira educação, os alunos devem construir, com auxílio dos professores-educadores, o plano de formação a partir das especificidades regionais.

Finalizamos, portanto, essa provocação inicial, procurando entender de onde vem o formato de escola do campo, que parece ser menos do campo do que deveria ser. E aqui está um dos grandes desafios dessa educação proibida.

\section{Formação dos professores-educadores do campo}

A mudança na estrutura formativa de profissionais que atuam no ensino voltado a alunos provenientes do campo é urgente. Apresentaremos, então, elementos de uma formação de professores-educadores que atuam em um curso superior de Tecnologia em Agropecuária ${ }^{1}$ da Universidade Regional Integrada do Alto Uruguai e das Missões, campus de Frederico Westphalen - RS $(\mathrm{URI} / \mathrm{FW})^{2}$, e que propõem formação de agricultores de nível superior, com base nas formações em alternâncias.

\footnotetext{
${ }^{1}$ Portaria n. ${ }^{2} 299$, de 7 de julho de 2016.

${ }^{2}$ Portaria n. ${ }^{\circ}$ 665, de 5 de novembro de 2014: a secretaria de regulação e supervisão da educação superior, no uso de suas atribuições e considerando as disposições da Lei n. ${ }^{\circ} 12.881$, de 12 de novembro de 2013, e da Portaria n. ${ }^{\circ} 863$, de 3 de outubro de 2014, do Ministério da Educação, e com fundamento na Nota Técnica n. ${ }^{\circ}$ 1.031/2014-DPR/SERES/MEC, resolve: Art. $1^{\circ}$ - Fica
} 
Inicialmente, precisamos retomar a ideia de que a educação do campo foi historicamente negada, considerada arcaica, atrasada, porque seus formadores raramente tiveram origem no campo. Portanto, não conhecendo o campo, sua cultura, sua tecnologia, seu manejo, como poderiam auxiliar na educação dos que lá trabalham?

Auxiliar no desenvolvimento do campo significa estar educado pelo campo, mas como propor isso se estamos diante de um mundo em que o discurso pedagógico sobrepõe o sujeito pedagógico? Para Díaz (1999, p. 15), "não existe sujeito pedagógico fora do discurso pedagógico”, isto é, aquele é formado e regulado por esse, pelo que está na ordem do dia; enfim, o que o sistema, as agências de controle preconizam.

Para Foucault (2013), a prática do discurso é um conjunto de enunciados que existem e se apoiam na mesma formação do discurso:

Chamaremos de discurso um conjunto de enunciados, na medida em que se apoiem na mesma formação discursiva; ele não forma uma unidade retórica ou formal, indefinidamente repetível e cujo aparecimento ou utilização poderíamos assinalar (e explicar, se for o caso) na história; é constituído de um número limitado de enunciados para os quais podemos definir um conjunto de condições de existência (Foucault, 2013, p. 143).

As práticas discursivas não podem ser confundidas com a formulação de ideias, uma atividade prática, um desejo. Diaz (1999) afirma que não existe sujeito pedagógico fora de um discurso pedagógico. Entretanto, precisamos tomar o cuidado para que esse discurso não seja entendido como menciona Foucault:

Finalmente, o que se chama de "prática discursiva" pode ser agora precisado. Não podemos confundi-la com a operação expressiva pela qual um indivíduo formula uma ideia, um desejo, uma imagem; nem com a atividade racional que pode ser acionada em um sistema de inferência (Foucault, 2013, p. 143).

qualificada como Instituição Comunitária de Educação Superior (ICES) a Universidade Regional Integrada do Alto Uruguai e das Missões - URI, Código e-MEC 423, mantida pela Fundação Regional Integrada - FURI, CNPJ n. ${ }^{\circ}$ 96.216.841/0001-00. Art. $2^{\circ}$ - Esta Portaria entra em vigor na data de sua publicação. 
Precisamos, então, avançar no sentido de falar em múltiplas pedagogias, a fim de entender as práticas pedagógicas e como se apoiam na mesma formação discursiva, o que, no conjunto, constituirá a formação de professores-educadores. Deve-se ter em mente que, de alguma maneira, as práticas educativas voltadas para o campo podem constituir-se de um jogo de poder, originadas de forças externas, e que, por consequência, corroemos valores culturais internos da educação do campo. Assim, ser um professor-educador do campo contando apenas com uma didática tradicional não basta: faz-se necessário o entendimento do discurso pedagógico, que fragiliza o campo. Para Miguel Arroyo:

Esta pode ser uma característica fundamental da educação básica do campo, porque essa é uma característica dos movimentos sociais, ser feitos por sujeitos, valorizar as pessoas, respeitar suas diversidades, seus direitos. Então, a primeira característica: vincular a educação com os direitos, vincular a educação com os sujeitos. Os sujeitos concretos, históricos tratados como gente na escola (Arroyo, 2004, p. 76).

Sem respeitar os espaços do campo e vincular a educação à sua realidade, não é possível pensar na formação dos sujeitos do campo; portanto, a única saída é respeitar a diversidade do campo e formar professores-educadores com um discurso voltado àquele espaço.

\section{Formação do professor-educador: a primeira proposta pedagógica de Ensino Superior do Pronera, com beneficiários do crédito fundiário}

Desenvolver um Curso Superior de Tecnologia em Agropecuárias, com beneficiários do crédito fundiário, por meio do Pronera (Programa Nacional de Educação na Reforma Agrária), ${ }^{3}$ em formação por alternância, foi um desafio para URI/FW. O referido programa foi construído com a comunidade

\footnotetext{
${ }^{3}$ São beneficiários do Pronera, conforme art. 13 do Decreto n. ${ }^{\circ} 7.352 / 2010$ : "População jovem e adulta das famílias beneficiárias das Áreas de Reforma Agrárias criadas ou reconhecidos pelo INCRA e do Programa Nacional de Crédito Fundiário (PNCF), de que trata o parágrafo $1^{\circ}$ do art. $1^{\circ}$ do Decreto ${ }^{\circ}$ 6.672, de 02 de dezembro de $2008^{\prime \prime}$.
} 
regional, os agricultores e os movimentos sociais que atuam junto a esses beneficiários.

Mesmo oferecendo uma formação voltada à sucessão do campo e já contando com um curso superior na área de Agropecuária com um histórico de formação voltado ao campo, com perfil de formação avaliado pelo INEP/MEC como inovador e recomendado para todas as regióes eminentemente rurais do Brasil, com conceito 5 (em escala de 1 a 5 ) nos objetivos do projeto pedagógico, não nos parece suficiente. As tecnologias vão tomando outras forma e os professores, sujeitos pedagógicos, facilmente poderão ser tomados pelo discurso pedagógico, bem como repetir erros crassos na formação de seus educandos.

Para tanto, elaborou-se um plano de formação dos professores-educadores, também em alternância, a fim de que exercessem, no decorrer do ano, uma vivência real dos instrumentos da formação em alternância e de que, ao viverem essa experiência, pudessem entender o processo de formação dos professores-educadores em alternância. Já no final do primeiro encontro, não restava dúvida de que havia o desejo do coletivo de professores-educadores em dar continuidade à "formação dos formadores em alternâncias".

O objetivo passou a ser possuir uma dinâmica de formação em alternância para os professores-educadores que atuam no Curso Superior de Tecnologia em Agropecuária - URI/FW. Essa dinâmica já havia sido entendida pela coordenação, NDE - Núcleo Docente Estruturante-, e seu colegiado como necessária, mas ainda não havia sido praticada. Estávamos, então, diante de uma oportunidade: o início da formação de beneficiários do crédito fundiário por meio do Pronera. A partir disso, foi implementada a formação de professores-educadores em uma educação conquistada a duras lutas, mas proibida pelo discurso hegemônico de uma sociedade que tem a educação voltada à produção e não à emancipação dos sujeitos.

O início da formação de beneficiários do crédito fundiário por meio do Pronera deu-se a partir do primeiro semestre de 2014, e foi no decorrer deste ano que se constituiu a ideia de formação dos professores-educadores. A dinâmica de formação dos cursos do Pronera exige planejamento, organização e acompanhamento social do processo educacional, que é princípio básico do programa nacional. Por essa razão, com o constante diálogo entre o colegiado, levado frequentemente ao NDE do curso, observa-se a necessidade de ampliar o conceito de aprendizagem existente nos professores-educadores, pois muitos ainda trazem arraigadas em suas práticas docentes uma educação tradicional, distante da realidade do campo. 
A caminhada se fez caminhando; e é no decorrer do ano de 2014 que surge a necessidade de uma formação dos professores-educadores. Importante destacar que a proposta de mudanças nas práticas docentes não foi imposição do programa, coordenação, direção da universidade, mas do coletivo de professores, por meio do debate regional e social, que constatou a necessidade de avanços pedagógicos e práticos. Também é importante destacar que o processo anterior existente em nossa universidade, de ação do Curso Superior de Tecnologia na área de Agropecuária já existente, possui bagagem de aproximação de uma formação voltada ao campo, à sucessão do campo, à formação de nível médio e superior para o campo. Ressalta-se que essa experiência do curso foi preponderante na iniciativa de formação dos professores-educadores. Durante o ano de 2014, foram ocorrendo reuniões e atividades de formação conforme a necessidade. A reunião que estabeleceu a ideia de formação em alternâncias para os professores-educadores se deu em 15 de agosto de 2014, com o primeiro plano de estudo sobre os princípios da pedagogia da alternância e que seriam, então, o tema gerador da primeira alternância no início de 2015. Em 12 de fevereiro de 2015, inicia a primeira alternância de formação de professores-educadores, com um plano de formação previamente estabelecido, fruto das discussões anteriores.

A seguir, apresenta-se uma tabela que demonstra a organização das alternâncias de formação de professores-educadores nos anos de 2015, 2016 e 2017.

A formação dos professores, seguindo os princípios da pedagogia da alternância, divididos dois tempos e espaços de formação, um denominado TC (Tempo-Comunidade) ${ }^{4}$ e outro TU (Tempo-Universidade), 5 passa a ser vivido, pelos professores, com um plano de formação, resultante do levantamento da realidade em curso, com um tema gerador. A cada alternância, é elaborado um plano de estudo no final do TU, a fim de ser estudado, vivido, compreendido, investigado, discutido, sistematizado no TC, que passa a ser

\footnotetext{
${ }^{4} \mathrm{O}$ Tempo-Comunidade é o período em que o estudante permanece em seu espaço socioprofissional, cultural, e desenvolve suas atividades profissionais, mediante um plano de estudo, com instrumentos pedagógicos da alternância; portanto, período de estudo no Tempo-Comunidade é momento de observar, mas também de implementar ações individuais e coletivas.

${ }^{5} \mathrm{O}$ Tempo-Universidade é o momento de reflexão sobre as suas ações implementadas e as novamente observadas, é o período em que o estudante está com seus colegas, professores e com instrumentos pedagógicos da alternância. Esse tempo possibilita ao educando refazer seus estudos e implementá-los no Tempo-Comunidade.
} 
apresentado individualmente ou coletivamente na colocação em comum da alternância seguinte, no TU, como ponto de partida do estudo.

Quadro 1: Síntese do plano de formação, dos professores-educadores no Curso Superior de Tecnologia em Agropecuária, da URI/FW, nos anos de 2015, 2016, 2017.

\begin{tabular}{|c|c|c|c|}
\hline \multirow{2}{*}{ Alternâncias } & \multirow{2}{*}{$\begin{array}{c}\text { Temas em estudo no Tempo-Comunidade (TC) } \\
\text { e no Tempo-Universidade (TU) }\end{array}$} & \multicolumn{2}{|c|}{ Carga horária } \\
\hline & & TC & $\mathrm{TU}$ \\
\hline $\begin{array}{l}\quad 1^{\mathrm{a}} \\
\text { I semestre de } \\
2015 \\
(12 \text { de fevereiro } \\
\quad \text { de } 2015)\end{array}$ & $\begin{array}{l}\text { - Origem da Pedagogia da Alternância (PA) } \\
\text { - Princípios da PA } \\
\text { - Instrumentos pedagógicos da PA } \\
\text { - Realidade e perspectivas da agricultura familiar } \\
\text { - Perfil do Curso Superior de Tecnologia em } \\
\text { Agropecuária e os alunos em formação }\end{array}$ & 04 & 08 \\
\hline $\begin{array}{l}2^{\text {a }} \\
\text { II semestre de } \\
2015 \\
\text { (15 e } 16 \text { de } \\
\text { julho de } 2015)\end{array}$ & $\begin{array}{l}\text { - Característica da região e identidade regional } \\
\text { dos beneficiários do crédito fundiário } \\
\text { - Qual a realidade regional? } \\
\text { - Curso como um projeto de mudança econômi- } \\
\text { ca e social da região } \\
\text { - Projeto profissional e de vida }\end{array}$ & 08 & 16 \\
\hline $\begin{array}{l}3^{a} \\
\text { I semestre de } \\
2016 \\
(17 \text { e } 18 \text { de } \\
\text { fevereiro de } \\
2016)\end{array}$ & $\begin{array}{l}\text { - Instrumentos pedagógicos da PA } \\
\text { - O futuro da região e dos beneficiários do crédi- } \\
\text { to fundiário: que região queremos? } \\
\text { - Princípios de desenvolvimento do campo: } \\
\text { Pronera - seus objetivos e fundamentos de } \\
\text { formação do campo }\end{array}$ & 08 & 16 \\
\hline $\begin{array}{l}4^{\mathrm{a}} \\
\text { II semestre de } \\
2016 \\
\text { (18 e } 19 \text { de } \\
\text { julho de } 2016)\end{array}$ & $\begin{array}{l}\text { - Realidade da região dos acadêmicos e suas fa- } \\
\text { mílias } \\
\text { - Conceitos e princípios do projeto profissional } \\
\text { e de vida } \\
\text { - Instrumentos pedagógicos da PA } \\
\text { - Revisão do roteiro para o projeto profissional e } \\
\text { de vida }\end{array}$ & 08 & 16 \\
\hline
\end{tabular}




\begin{tabular}{|c|c|c|c|}
\hline $\begin{array}{c}\quad 5^{\mathrm{a}} \\
\begin{array}{l}\text { I semestre de } \\
2017\end{array} \\
\text { (11 de janeiro } \\
\text { de 2017) }\end{array}$ & $\begin{array}{l}\text { - Comunidade educativa } \\
\text { - Parceiros do Curso Superior de Tecnologia em } \\
\text { Agropecuária da URI-FW } \\
\text { - Revisáo dos fundamentos e princípios da PA }\end{array}$ & 04 & 08 \\
\hline $\begin{array}{c}6^{\mathrm{a}} \\
\text { II semestre de } \\
2017 \\
\text { (06 de julho de } \\
2017)\end{array}$ & $\begin{array}{l}\text { - Qual o mecanismo que motiva o aluno a seguir } \\
\text { na sucessão rural - "Psicologia de ser agricul- } \\
\text { tor"? } \\
\text { - Os sujeitos em formação estão diante de uma } \\
\text { modernidade cada vez mais líquida }\end{array}$ & 04 & 08 \\
\hline $\begin{array}{c}7^{a} \\
\text { I semestre de } \\
2018 \\
\text { (a realizar-se } \\
\text { nos dias } 22 \text { e } 23 \\
\text { de fevereiro de } \\
\text { 2018) }\end{array}$ & $\begin{array}{l}\text { - Continuidade dos estudos sobre o tema "Psico- } \\
\text { logia de ser agricultor" } \\
\text { - Com quem dialogam os agricultores familiares? } \\
\text { - Diferentes aprendizagens na formação do su- } \\
\text { jeito } \\
\text { - Características do mundo contemporâneo e a } \\
\text { sucessão do campo }\end{array}$ & 08 & 16 \\
\hline $\begin{array}{l}\quad 8^{a} \\
\text { II semestre de } \\
\quad 2018 \\
\text { (a data será defi- } \\
\text { nida no final da } \\
\text { 7a alternância) }\end{array}$ & (tema será definido no final da $7^{\mathrm{a}}$ alternância) & & \\
\hline \multicolumn{2}{|c|}{ Total de horas - 2015, 2016 e 2017} & 44 & 88 \\
\hline
\end{tabular}

Fonte: elaborada pelo autor, a partir dos registros dos livros de atas do Curso Superior de Tecnologia em Agropecuária (URI/FW).

Esse princípio, base da alternância de partir da realidade existente, é importante para de gerar reflexão no TU e, consequentemente, novas ações no TC e na vida futura do educando. Ao todo, durante os três anos de existência do projeto de formação de professores, foram seis alternâncias, totalizando 44 horas no TC e 88 no TU. Elas foram construídas de forma semestral, possibilitando ao professor observar, refletir e agir sobre suas atividades socioprofissionais, vivendo as formações em alternâncias. 
A formação seguiu uma organização resultante da realidade existente no primeiro ano, foram temas voltados para o conhecimento da origem e de princípios da formação em alternância, da realidade dos educandos e da região em que o curso está inserido. No segundo ano de formação, os temas se voltaram aos instrumentos pedagógicos da alternância, ao projeto profissional e de vida dos educandos. No terceiro, os temas foram direcionados para o estudo da comunidade regional, para os parceiros do curso e aprofundamento dos instrumentos pedagógicos deste. Por sua vez, o quarto ano de formação teve início com o debate de como pensam os agricultores, a sua psicologia diante de um mundo contemporâneo, extremamente fluido, com inúmeras tecnologias e fortemente influenciado por agentes externos à vida do campo.

É importante lembrar que os temas geradores das alternâncias vão sendo construídos no decorrer dos anos, de acordo com os desafios do mundo contemporâneo e as necessidades reais do curso, sempre observando a realidade dos educandos e seus professores-educadores.

\section{Formações em alternâncias}

Iniciamos apontando que, de maneira geral, toda formação de professores tem um princípio de "alternância" (Couceiro, 2002), pois parte dos educadores está em atividade socioprofissional, espécie de tempo de comunidade, e outra parte, em tempo de universidade, em formação continuada. Porém, parece que a alternância de sucessão de tempos e espaços é uma falsa alternância. De acordo com os postulados de Gimonet (2007), seria a alternância justaposta apenas uma sucessão de estudos, com idas e vindas.

Alternâncias, ${ }^{6}$ entendidas como ideia de conjunto e continuidade, existem a partir da interdependência entre si, ou seja, uma alternância inicia antes de a outra estar concluída, e a próxima somente existirá em função de a anterior ter existido. Ainda, é necessário considerar que não existem tempo e espaço de estudo únicos; o que existe é um coletivo de temas, teorias e práticas que constituem, pouco a pouco, o conhecimento necessário para o desenvolvimento de algo inovador. Para Nosella (2014, p. 172), “é com esse objetivo de

${ }^{6}$ Duffaure e Robert, 1955. 
integração do tempo de escolaridade obrigatória com o tempo da 'liberdade' formativa que o movimento pedagógico da Pedagogia da Alternância nasceu e se desenvolveu".

A ideia de formações, por um lado, está vinculada à formação profissional para satisfazer as necessidades do setor produtivo, educação-produção, em que há melhora das condições individuais; por outro, visa atender aos objetivos-fins da educação, que é a formação integral do ser humano, educação-cidadania, formação para democracia, com a finalidade de formar um sujeito capaz de pensar processos de desenvolvimento (Cabrito, 1994).

Então, partimos do pressuposto de que existem duas formações em um processo de formação em alternâncias. Nesse processo de formação de professores apresentado, experimentamos uma dinâmica de formação continuada de professores-educadores capaz de elaborar, organizar usos de tecnologias e, ao mesmo tempo, democratizar a vida dos educandos, desenvolvendo novos sistemas produtivos sustentáveis.

Possibilitar que o sujeito se aproprie de uma formação para democracia e ainda desenvolva vivências com o setor produtivo parece ser algo extremamente necessário na formação de professores-educadores no mundo contemporâneo.

$\mathrm{Na}$ formação em alternância, o professor é reconhecido como um educador que transcende a docência e passa a ajudar o educando no processo de formação, em seu Tempo-Comunidade e Tempo-Universidade. Dessa forma, os docentes desenvolvem responsabilidade educativa de orientação e acompanhamento dos educandos nas vivências de grupo e fora delas.

Segundo Gimonet (2007, p. 146), "na pedagogia tradicional o 'mestre' se confunde com o conhecimento", pois o mestre, professor, precisa saber mais que o aluno, ter mais conhecimento. No processo aqui apresentado, a postura é diferente, uma vez que a ideia de professor-educador, aquele que possui conhecimento, é o que cuida do educando, da sua formação e se preocupa com a preparação da sociedade para receber quem está em formação.

O professor-educador permeia a complexidade. Portanto, atravessa as questões educacionais, sociais, pedagógicas e, principalmente, profissionais dos seus educandos. O profissional se apresenta como um conhecedor de uma determinada área, mas possui uma função interdisciplinar e transdisciplinar, que permite associar problemas do cotidiano com o científico existente.

Essa profissão de professor-educador não se improvisa, pois precisa de formação, de estudo, de observação, de aproximar-se do ensino, da pesquisa 
e da extensão. Portanto, uma formação de professores-educadores em alternância será sempre continuada e ampliativa da capacidade de conhecimentos humanos.

A educação continuada em alternância tem por objetivo desenvolver elementos que possam discutir e associar, nos diferentes espaços de formação e ao longo da vida profissional do sujeito, temas, conteúdos que sirvam para atualização em seu meio socioprofissional e, ao mesmo tempo, de ordem pedagógica, nas atividades próprias de educação, de sua formação, como podemos constatar no quadro que segue, que configura a ideia da sequência proposta pela formação em alternância:

Figura 1: Pedagogia da Alternância

TEMPO COMUNIDADE

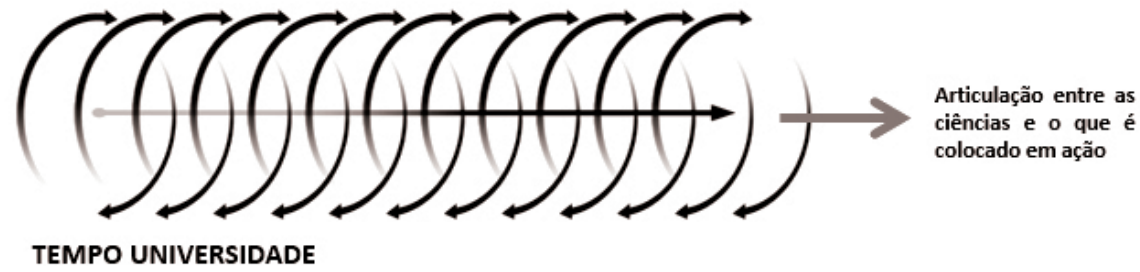

MOMENTO FORMATIVOS QUE COEXISTEM

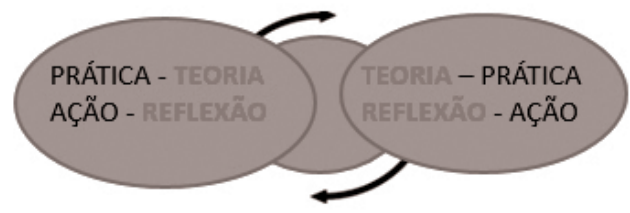

Fonte: 0 autor.

Os momentos sucessivos em que os professores-educadores alternam os períodos no Tempo-Comunidade, seu meio socioprofissional, e outros no Tempo-Universidade, meio educacional, possibilitam observar, criar hipóteses, problematizar e não desvincular a teoria da prática. Segundo Veiga-Neto (2016, p. 20), "se os enunciados e as palavras que constituem uma teoria, só tem significado na corrente do pensamento e da vida”. Enfim, tornar possível o conhecimento, indistintamente conectado à sua realidade, aos seus afazeres, significa estudar e trabalhar ao longo da vida. 


\section{Aprendizagens obtidas}

A formação de educadores em alternância pode ser um simples método pedagógico ou dar origem a um sistema educativo (Gimonet, 1999). Por esse viés, é uma pedagogia que passa a ser um conjunto de pedagogias, aproximando a realidade vivida, uma identidade pessoal e socioprofissional do professor-educador aos problemas reais da vida do educando, do cotidiano, da sociedade.

Pensar a educação como princípio pedagógico estratégico para o desenvolvimento sustentável é partir da ideia de que o território pode e deve ser reinventado por meio das suas potencialidades. A formação de educadores deve e pode ser conduzida por meio de parâmetros existentes e vividos na própria realidade.

As alternâncias desenvolvidas apontam dois elementos fundantes na formação de professores-educadores para uma educação esquecida, negada e proibida. Um elemento está centrado no desenvolvimento local; o outro, no fortalecimento da cooperação. Observamos o primeiro em Puig-Calvó (2002, p. 126), quando afirma que "sem formação não há desenvolvimento pessoal. Sem desenvolvimento pessoal, não há desenvolvimento local sustentável. Sem desenvolvimento local, não há desenvolvimento pessoal integrado".

A formação pessoal leva o sujeito a desenvolver, mediante suas capacidades, o poder de agências (Schneider, 2014), a ampliação do capital humano (López-Ruiz, 2007), que melhora a capacidade das pessoas em lidar com as diferenças humanas. Portanto, estamos diante do segundo elemento, a cooperação, e buscamos em Sennett uma breve contextualização: "as pessoas perdem a capacidade de lidar com as diferenças insuperáveis, à medida que a desigualdade material as isola, que o trabalho de curto prazo torna mais superficiais os contatos sociais e gera ansiedade a respeito do outro" (Sennett, 2013, p. 20).

O fortalecimento da cooperação está em primeiro lugar. No momento em que nos aproximamos da formação, observando a realidade existente, a potencialidade de cada indivíduo coletivo, entendemos que precisamos cooperar, a fim de não ampliar o individualismo material que gera ansiedade a respeito do outro. 
Portanto, o principal aprendizado dessa formação de educadores, em um curso superior que trabalha a formação de agricultores para sucessão do campo, nos parece diretamente ligado à cooperação e ao desenvolvimento local. Apontamos, aqui, inúmeras contribuições no processo de formação dos professores-educadores que servirão de instrumentos pedagógicos na prática docente e de desenvolvimento local:

1. No ensino, seja de educação básica ou superior, é necessário que os gestores gastem $50 \%$ do seu tempo pensando na formação dos professores-educadores;

2. A formação dos professores-educadores contribui para efetivar os objetivos de um curso, do ensino, do perfil de sociedade que desejamos;

3. Uma maneira de integrar ensino, pesquisa e extensão às atividades de formação;

4. Rápida aproximação da equipe de formadores com a comunidade regional;

5. Possibilidade de atender ao chamado da comunidade no desenvolvimento de projetos e pesquisas;

6. Valorização dos egressos, que são a comunidade na abrangência da escola, da universidade, reforçando a ideia de aprendizado continuado;

7. Desenvolvimento da inter e da transdisciplinaridade, momento em que os educandos aprendem, participam e transformam as suas vidas e as da comunidade por meio da ciência;

8. Consolidação da ideia de que a prática se origina a partir das reflexões teóricas, e as reflexões teóricas, de inúmeras práticas feitas;

9. A possibilidade de fazer reunião de pais, colegiado, apresentação de trabalho de conclusão de curso, ciclo de experiências, pois ensino se faz dentro e fora da escola, da universidade;

10. Oportunidade de fazer a formação em alternância como dinâmica pedagógica, que ultrapassada os campos da educação e produção; com isso, há a integração, a associação e a criação de mecanismos de mediação, fortalecendo-se a vida humana.

Estamos diante de uma formação de professores-educadores em alternâncias, que apresenta o ontem, o hoje e o amanhã (Gimonet, 2007). O ontem, nas experiências vividas, construídas a duras penas, pois não podemos esquecer que estamos diante de um sistema que se opõe à ideia de construir 
conhecimento, de desenvolver o espírito da coletividade; do hoje, pela existência de uma prática ainda inconclusiva e de que temos o desafio de fazer o futuro melhor, sob a ótica personalista e construtivista. O desafio maior é trabalhar em prol de uma cidadania planetária, num mundo cada vez mais líquido (Bauman e Donskis, 2014), com tecnologia de informação, mas que, mesmo com toda a dinâmica que a pós-modernidade subentende, necessita que a formação seja permanente ao longo de toda a vida.

\section{Os desafios seguem}

As escolas e universidades estão entre quatro paredes, exercendo o poder sobre indivíduos, por meio de julgamento, controle, punição, mediações, individualizando a sociedade, tornando-a objeto de futuras ações da maquinaria do poder. Para Foucault (1997), no momento em que as pessoas não são consultadas, interrogadas para dizer sobre si mesmas, não estão possuindo oportunidades de construir a sua identidade; então, o poder exercido sobre elas é que constrói o regime de verdade sobre o indivíduo.

Como estamos diante de seres humanos, dotados de capacidades de aprendizagem, devemos formar educandos com capacidades cognitivas frente a um mundo cada vez mais fluido, mergulhados em uma modernidade líquida (Bauman, 2016). Como estamos vendo esse sujeito diante deste mundo de oportunidades e ameaças? O que estamos fazendo para capacitá-lo a interagir no/com o mundo que o cerca? Estamos ouvindo nossos educandos?

Acredito na formação de professores-educadores, e os gestores precisam, sim, dedicar parte do seu tempo pensando no sistema, criando projetos e tomando parte na formação continuada, a fim de vermos as escolas e universidades ressurgirem, desenvolverem novas verdades, frutos de novos mecanismos de educação, voltados à vida humana. Vemos, em Donskis, mais que um desafio: "observar as universidades morrerem lentamente, ou criar algumas alternativas que irão durar mais tempo que os poucos mandatos cumpridos por políticos no parlamento e no governo?" (Bauman e Donskis, 2014, p. 163).

O fato de apregoarmos a liberdade acadêmica, o que isso significa para uma classe política que proíbe a educação (Bauman e Donskis, 2014) e que nega à sociedade o direito de educação? 
A formação de professores-educadores precisa ser capaz de dizer, fazer, articular o que efetivamente precisa ser feito, independentemente da educação, hoje, ser quase mercado. Para Bauman (2014, p. 169), "se os professores não conseguem articular aquilo que fazem nem dizer por que isso importa em termos não contemplados pelo mercado, quem poderá fazê-lo?”. Está claro que precisamos desenvolver uma consciência planetária e de desenvolvimento humano, uma educação-cidadania conectada à educação-produção e sempre voltada à democracia.

O que normalmente temos observado é o que salienta Bauman e que se refere à dominação: as iniciativas não passam de uma forma de sobrevivência dentro de uma educação quase mercado, que corrompe tudo e todos, e "toda e qualquer pequena mudança de disposição do mercado (essa 'mãe' de todas as incertezas) são consequência da estratégia de dominação do deixem que flutuem (leia-se, deixe que nadem ou afundem)" (Bauman e Donskis, 2014, p. 170).

Desejamos preparar jovens para a vida, "num mundo que torna nula e vazia a própria ideia de ser preparado” (Bauman e Donskis, 2014, p. 171). Isso remete à necessidade de pensarmos sobre a formação que recebemos para sermos professores-educadores, e é urgente discutirmos isso na formação dos professores, a fim de pensarmos que estratégias que possam dar conta de uma educação para democracia devem ser construídas ao longo da formação dos acadêmicos.

O sistema atual, engendrado pelo mecanismo de produção, leva as instituições de ensino a arrancar do jovem suas raízes:

Se você tira de uma pessoa discordante ou hostil o direito de ter raízes, seu solo político e cultural, se abriga a permanecer sempre em movimento, privando-a em última instância de um censo de lar, companheirismo, proteção, segurança e certeza, estará condenando-a a uma forma bastante humanitária de morte lenta (Bauman e Donskis, 2014, p. 194).

Então, estamos diante de um grande dilema movido pelo sistema de produção e não da educação. E quando a educação busca elementos de acesso, a exemplo do Sisu, ${ }^{7}$ acaba respondendo justamente a esse imperativo, que é

${ }^{7}$ Sistema de Seleção Unificada. 
tirar o jovem do seu lar, a fim de roubar a sua identidade, obrigando-o a construir outra que nunca será a sua verdadeira. Será sempre um sujeito hostil e sem raízes, sem capacidade de adotar a democracia em sua plenitude. Estamos diante de um desafio, que é educar a partir da produção, sem perder de vista a democracia.

Os desafios seguem porque precisamos cuidar de duas questóes cruciais para a formação de sujeitos do campo, a fim de construir regimes de verdade na sociedade em que constituem suas ações:

1. Uma questão está centrada na capacidade de construir saberes coletivamente, no sentido de encontrar tecnologias mais apropriadas para o produtivismo. A premissa é a de ter a capacidade de colegamento, ${ }^{8}$ união para construção de regimes de verdade, a partir dos sujeitos do campo. Tal atitude evitaria a falência de nós mesmos (Bauman e Donskis, 2014), e seriam os envolvidos nessa proposta as vozes críticas e contestadoras da sociedade.

2. Outra questão que compromete fortemente a formação dos educandos do campo está na capacidade dos professores-educadores de não reproduzirem a afirmação de que o problema está na sociedade, nas práticas ruins dos individualizados do campo. Parece que a culpa está nos sujeitos do campo, que são atrasados, esquecendo-se das práticas de discurso que formulam regimes de verdades.

Uma formação de professores-educadores em uma educação proibida, educação do campo, está diretamente vinculada às práticas do discurso que apontamos a partir de Foucault. Estamos diante de uma sociedade que constrói regimes de verdade com base no sistema de produção, não da educação, e se acentuam no campo as ideias de "eu produto", "empresário de si" (López-Ruiz, 2007). Portanto, nosso desafio é avançar em sistemas de formação de professores-educadores de forma contínua, o que nos parece extremamente viável na ideia de "formações em alternâncias".

\footnotetext{
${ }^{8}$ Colegamento, no sentido de ampliar a ideia de colega de trabalho, de estudos, ir além, pensar soluções, saída que demonstre união e desenvolvimento das pessoas.
} 


\section{Referências}

ARROYO, M. et al. (orgs.). Por uma educação do campo. Petrópolis: Vozes, 2004.

BAUMAN, Z. Modernidade líquida. Rio de Janeiro: Jorge Zahar, 2001.

e DONSKIS, Leonidas. Cegueira moral: a perda da sensibilidade na modernidade líquida. Trad. Carlos Alberto Medeiros. Rio de Janeiro: Zahar, 2014.

CABRITO, Belmiro Gil. Formações em alternância: conceitos e práticas. Lisboa: Educa, 1994.

CALVÓ, P. P. “Formação pessoal e desenvolvimento local”. In: UNEFAB União Nacional das Escolas Famílias Agrícolas do Brasil. Pedagogia da alternância: formação em alternância e desenvolvimento e sustentável. Brasília: UNEFAB, 2002.

CAMBI, Franco. História da Pedagogia. Trad. Álvaro Lorencini. São Paulo: Editora UNESP, 1999.

COUCEIRO, M. L. Paiva. "Formação universitária em alternância em Portugal”. In: UNEFAB - União Nacional das Escolas Famílias Agrícolas do Brasil. Pedagogia da alternância: formação em alternância e desenvolvimento sustentável. Brasília: UNEFAB, 2002.

DÍAZ, Mario. "Foucault, docentes e discursos pedagógicos". In SILVA, Tomaz Tadeu da (org.). Liberdades reguladas: a pedagogia construtivista e outras formas de governo do eu. Petrópolis: Vozes, 1999.

DUFFAURE, André e ROBERT, Jean. Une méthode active d'apprentissage agricole. Paris: AIMFR, 1955.

FOUCAULT, Michel. Microfísica do poder. 11 ed. Rio de Janeiro: Graal, 1997.

. A arquelogia do saber. 8 ed. Rio de Janeiro: Forense Universitária, 2013.

GIMONET, J. C. Praticar e compreender a pedagogia da alternância dos CEFFAs. Petrópolis: Vozes, 2007.

"Nascimento e desenvolvimento de um movimento educativo: as Casas Familiares Rurais de Educação e Orientação". In 
Pedagogia da Alternância: Alternância e Desenvolvimento. Primeiro Seminário Internacional. Brasília: UNEFAB, 1999.

LÓPEZ-RUIZ, Osvaldo. Os executivos das transnacionais e o espirito do capitalismo: capital humano e empreendedorismo como valores sociais. Rio de Janeiro: Azougue, 2007.

NOSELLA, Paolo. “Educação: território e globalização". In BAUER, Carlos et al. (orgs.). Pedagogias alternativas. Jundiaí: Paco Editorial, 2014.

SCHNEIDER, S. "Evolução e Características da Agricultura Familiar no Brasil”. Revista da ALASRU Nueva Época, v. 1, pp. 21-52, 2014.

e GAZOLLA, Marcio. "Os atores entram em cena". Os atores do desenvolvimento rural: perspectivas teóricas e práticas sociais. 1 ed. Porto Alegre: Editora da UFRGS, 2011.

SENNETT, Richard. Juntos. Trad. Clóvis Marques. 2 ed. Rio de Janeiro: Record, 2013.

VEIGA-NETO, Alfredo. "De geometrias, currículos e diferenças". Educação \& Sociedade, ano XXIII, n. 79, pp. 163-86 Campinas, ago. 2002. . Foucault e educação. 3 ed. Belo Horizonte: Autêntica, 2016. 


\title{
Experiências de um grupo de pesquisa na formação de professores
}

\author{
0 GPET-UFSM
}

Cesar De David

Janete Webler Cancelier

\begin{abstract}
O conhecimento não se estende do que se julga sabedor até aqueles que se julgam não saberem; o conhecimento se constitui nas relações homem-mundo, relações de transformação, e se aperfeiçoa na problematização crítica destas relações (Paulo Freire).
\end{abstract}

\section{Introdução}

Neste texto, vamos descrever e discutir a trajetória do Grupo de Pesquisa em Educação e Território (GPET) - grupo de estudos, pesquisas e ações de extensão multidisciplinar da Universidade Federal de Santa Maria -, que, desde seu início, tem como foco a formação inicial e continuada de educadores. O GPET, por meio de suas diversas atividades, procura inserir docentes em serviço e acadêmicos em formação, dos cursos de graduação, e estudantes de pós-graduação da universidade no contexto da prática pedagógica, comprometida com as questões que articulam educação e território. Seus integrantes buscam vivenciar espaçotemporalmente a possibilidade de compreender crítica e responsavelmente formas diferenciadas de educação popular. Nessa práxis pedagógica, baseada no binômio ação-reflexão-ação, a educação ganha novos contornos, ultrapassando a dimensão escolar, construindo-se em meio a ambientes educativos formais e não formais.

O Grupo de Pesquisa em Educação e Território congrega pesquisadores e acadêmicos de diferentes áreas do conhecimento: Geografia, História, Pedagogia, Ciências Sociais, entre outros, que desenvolvem suas atividades de ensino, pesquisa e extensão tendo por princípios a preocupação com as deman- 
das de uma sociedade plural e desigual, como é o caso da sociedade brasileira, e a interlocução com os sujeitos das ações na perspectiva da troca de saberes e conhecimentos, reconhecendo e valorizando as diferentes culturas, como forma de promoção do saber popular e do conhecimento científico.

Nas temáticas relacionadas à educação e às dinâmicas territoriais, o GPET está organizado em torno de duas linhas de pesquisa: a) Educação e Sociedade - reúne projetos de pesquisa e extensão que tratam dos temas Educação do Campo, Pedagogia dos/nos Movimentos Sociais e Comunidades Tradicionais, Sociedade e Cultura em diferentes espaços pedagógicos; e b) Dinâmicas Territoriais - reúne projetos que, em seu conjunto, trabalham com as territorialidades da sociedade brasileira em suas diferentes dimensões e escalas, sobretudo as transformações recentes do espaço rural. Os temas tratados concentram-se nas dinâmicas socioeconômicas ligadas às atividades da agricultura familiar e camponesa, nas problemáticas do desenvolvimento territorial e nos estudos socioculturais no campo.

As atividades realizadas ao longo dos anos possibilitaram aos seus integrantes o acompanhamento da luta dos movimentos sociais e da constituição de sua pedagogia. A formação cidadã dos acadêmicos e sua sensibilização para trabalhar com realidades sociais e educacionais diferenciadas é uma das prioridades do Grupo de Pesquisa em Educação e Território ao articular suas atividades de ensino, pesquisa e extensão.

Essas atividades representaram um salto quanti/qualitativo no processo de interlocução entre a universidade e os movimentos sociais, pois possibilitaram não apenas o diagnóstico de problemas, mas a construção de alternativas e caminhos para a superação dos limites e dificuldades das escolas e demais espaços de aprendizagem, por meio do diálogo de saberes, cursos e oficinas às comunidades escolares. Essas medidas compreenderam momentos do processo de formação dos educadores dos movimentos, dos acadêmicos e de professores da universidade, ou seja, um componente cooperativo com o sujeito pedagógico, como referem as proposições da pedagogia da terra.

Com este texto, objetiva-se relatar a origem do GPET, sua trajetória, assim como descrever as atividades e estudos desenvolvidos pelo grupo. Utiliza-se como método de pesquisa uma abordagem de caráter qualitativo, tomando-se por referência o acervo documental do grupo, prioritariamente artigos, teses, dissertações, trabalhos de conclusão, relatórios de pesquisa, atas e demais documentos. 


\section{Os antecedentes}

Antes de sua formalização, ocorrida em 2005 como grupo de pesquisa registrado no Diretório de Grupos de Pesquisa da Plataforma Lattes do CNPq, o GPET já existia na prática desde 1996, quando iniciaram as atividades junto às Escolas Itinerantes do MST, integrando professores dos departamentos de Sociologia e Política, Geociências e Pedagogia da Universidade Federal de Santa Maria (UFSM) e estudantes dos cursos de Geografia e Pedagogia.

O marco inicial desse processo ocorreu em agosto de 1996, quando foi realizado um trabalho de campo no Acampamento Palmeirão, do Movimento dos Trabalhadores Rurais Sem Terra, situado no município de Júlio de Castilhos, onde estavam acampadas 1.421 famílias. ${ }^{1}$ Esse trabalho de campo ${ }^{2}$ foi promovido pelos professores Marisa Natividade e João Rodolfo Flores, da disciplina de Sociologia e Política. A visita a um acampamento de trabalhadores rurais sem terra foi a primeira oportunidade que muitos estudantes tiveram de conhecer as estratégias de ação dos movimentos sociais e interagir com eles. Como parte das atividades, discutiu-se a ação dos movimentos na região, oportunizando-se aos professores e estudantes envolvidos o contato com a proposta de educação do MST e a realidade da Escola Itinerante. Como resultado dessa experiência, organizou-se uma exposição fotográfica apresentada durante a Semana Acadêmica do Curso de Geografia, no ano de 1997, e elaborou-se o primeiro projeto de extensão submetido ao Prolicen $^{3}$ (Programa das Licenciaturas da UFSM), em sua primeira edição. Teve por objetivo oportu-

\footnotetext{
${ }^{1}$ Essa experiência é relatada e analisada em maior profundidade no texto: NATIVIDADE, Marisa de Oliveira. "De que marca é esse peixe?" In MEURER, Ane Carine e DE DAVID, Cesar. Espaços-tempos de itinerância: interlocuçóes entre universidade e escola itinerante do MST. Santa Maria: Editora UFSM, 2006.

${ }^{2}$ Por trabalho de campo, entendemos, como explica Radaelli da Silva (2002, p. 66), "uma e não única forma de construir conhecimento e de gerar atitudes e habilidades específicas do ensino da Geografia e, mais amplas, de formação social, pelo seu papel integrador, uma vez que estimula relações afetivas e cognitivas, da mesma forma que desenvolve uma percepção apreciativa do espaço geográfico num contexto menos formal que o da sala de aula tradicional".

${ }^{3}$ O Prolicen - Programa das Licenciaturas - é um programa institucional da UFSM que tem por finalidade oportunizar aos acadêmicos dos cursos de licenciatura o desenvolvimento de projetos de ensino, pesquisa e extensão, articulando a formação pedagógica na universidade com a realidade dos ambientes educativos, escolares e não escolares. O programa financia bolsas para os acadêmicos.
} 
nizar a ação-reflexão docente em realidades educacionais diferenciadas, como é o caso da Escola Itinerante. Desde então, em todas as edições do programa, o grupo tem sido contemplado com bolsas para os acadêmicos. Isso tem possibilitado não só a realização de projetos de extensão, mas o acompanhamento de várias ações de movimentos sociais do campo no Rio Grande do Sul, pois, em todo esse período, foram vários os acampamentos/comunidades atendidos em diversos municípios, entre os quais Júlio de Castilhos, Santo Antônio das Missões, Tupanciretã e São Gabriel.

As atividades realizadas proporcionaram aos integrantes o acompanhamento da luta dos movimentos sociais, associações, instituições e entidades que articulam sem-terras, camponeses e outros grupos sociais e sua pedagogia. A formação cidadã dos acadêmicos e sua sensibilização para trabalhar com realidades sociais e educacionais diferenciadas é u ma das prioridades do Grupo de Pesquisa em Educação e Território ao articular suas atividades de ensino, pesquisa e extensão.

As atividades realizadas nos últimos anos representaram um salto qualitativo no processo de interlocução entre a universidade e a sociedade, pois possibilitaram não apenas o diagnóstico de problemas, mas a construção de alternativas e caminhos para a superação dos limites e dificuldades das escolas, por meio do diálogo de saberes, cursos e oficinas à comunidade escolar, que compreendem momentos do processo de formação dos educadores dos movimentos/entidades e dos acadêmicos e professores da universidade, ou seja, um componente cooperativo com o sujeito pedagógico.

Essa prática oportunizou a reflexão sobre a Educação Popular e a Educação do Campo, temáticas que permeiam os projetos desenvolvidos em suas linhas de pesquisa.

Com a inserção de novos pesquisadores e a qualificação de seus integrantes, outras demandas surgiram, ampliando as temáticas dos projetos desenvolvidos, porém mantendo as características que dão identidade e coesão ao grupo. Assim, fortemente ligado à perspectiva das ações dos movimentos sociais e ao espaço rural, desenvolvem-se os projetos de pesquisa e extensão que têm como foco as dinâmicas territoriais, outra linha de pesquisa do GPET. $\mathrm{Na}$ sequência, apresentamos a trajetória do Grupo de Pesquisa em Educação e Território e as ações desenvolvidas ao longo dos anos.

As atividades desenvolvidas têm possibilitado que os acadêmicos e professores envolvidos nos projetos socializem saberes e reflexões sobre a educação 
popular, a questão agrária brasileira e a inserção e atuação dos movimentos sociais e de outros sujeitos do campo.

\section{A trajetória de um grupo de pesquisa}

A trajetória de um grupo de pesquisa, além da produção do conhecimento, centra-se na formação de pessoas, futuros profissionais da educação. Assim, a razão de sua existência em uma universidade pública, laica e referenciada socialmente é oferecer as condições necessárias para que a aprendizagem aconteça fora dos limites restritos das disciplinas acadêmicas. Ao articular pesquisa, ensino e extensão, tem-se a intenção de proporcionar um conhecimento baseado na indissociabilidade da teoria-prática, da reflexão-ação, como condição para a formação cidadã e para a transformação social.

Privilegia-se, assim, o diálogo entre as áreas do conhecimento, rompendo-se o cânone disciplinar, comum na academia, no sentido de um saber plural, multi e transdisciplinar, intrinsecamente ligado ao mundo da vida e do trabalho. Diferentes estratégias, tecidas nas açôes do cotidiano, compõem o itinerário de um grupo de trabalho que congrega professores e estudantes. Nossas práticas compõem-se de:

- Projetos de investigação, cujo objetivo primeiro é a produção do conhecimento. Levantamento bibliográfico, coletas de dados, entrevistas, mapeamentos e outras técnicas de pesquisa - atividades que inserem os estudantes na rotina do trabalho sistemático e responsável, segundo o método e as exigências do conhecimento científico. O reconhecimento e a valorização do saber popular, com o qual dialogamos, não exime o pesquisador do rigor conceitual e metodológico, pelo contrário, exige o compromisso com a vanguarda científica, o Estado da Arte, os métodos de abordagem e as mais recentes técnicas de pesquisa coadunadas com o espírito da descoberta e da criatividade;

- Projetos de extensão, cuja finalidade é a articulação dos saberes, na perspectiva da troca de conhecimentos/experiências, sobretudo entre os educandos em formação na universidade e os educandos em serviço, nos mais diferentes contextos escolares e não escolares. Entre os projetos de extensão, merece destaque o intitulado "A formação continuada de educadores em exercício das Escolas Itinerantes do Movi- 
mento dos Trabalhadores Rurais Sem Terra", desenvolvido no ano de 2005 com o apoio do Programa à Extensão Universitária (PROEXT) do Ministério da Educação;

- Projetos de ensino, que oportunizam a prática pedagógica e sua reflexão aos estudantes das licenciaturas, desde os anos iniciais de sua formação. Essa ação/reflexão se faz com os educadores em serviço, com os educandos da educação básica e com as comunidades escolares.

Entre os projetos desenvolvidos, merecem destaque, tanto pelas repercussões quanto pela abrangência, os seguintes:

- Projeto integrado de trabalho com professores e alunos das Escolas Itinerantes do MST. Foi o projeto pioneiro do grupo, realizado no período de 1997 a 2008, tendo acompanhado a formalização e reconhecimento da educação promovida pelas Escolas Itinerantes do MST até seu fechamento. Esse projeto tinha por objetivo a interlocução entre educadores leigos em exercício nessas escolas e os educadores em formação, alunos das licenciaturas da UFSM. Como parte das atividades desenvolvidas, destacam-se as oficinas de formação continuada, a produção de materiais didáticos, as metodologias de ensino-aprendizagem, cursos, seminários e estágios de vivências.

- A valorização do espaço agrário e a compreensão do lugar: o caso da Escola Estadual de Ensino Fundamental Joaquim José da Silva Xavier, em Val de Serra, Júlio de Castilhos, (RS). Desenvolvido em 2008, tinha por objetivo a compreensão das transformações recentes do espaço rural de Júlio de Castilhos RS, como forma de valorização da agricultura familiar e da comunidade rural onde a escola está inserida e de onde provêm seus educandos.

- Programa de Extensão e Pesquisa em Educação do Campo. A partir de 2008, os projetos de extensão, pesquisa e ensino foram agrupados em um projeto integrado, de caráter mais abrangente, de modo que contemplasse a diversidade das modalidades, práticas e experiências em educação do campo existentes em Santa Maria e região. São exemplos de projetos com essa proposta: "Educação rural, territorialidade e saber social: o caso das escolas rurais municipais de Santa Maria, RS" (2008); "Perfil da educação rural no município de Santa Maria/RS: problemas e perspectivas de valorização do campo e do 
saber social" (2008); "Formação continuada de educadores e educadoras das escolas da reforma agrária do Rio Grande do Sul" (2009); "Formação inicial e continuada de educadores das escolas do campo" (2010); "Formação de professores das Escolas do Campo: construção das diretrizes operacionais da Educação do Campo no município de Santa Maria, RS" (2010); "Projeto de extensão universitária em educação do campo: formação continuada de educadores da reforma agrária” (2010); "Desenvolvimento rural sustentável: resgatando saberes na escola municipal de ensino fundamental Bernardino Fernandes, Distrito de Pains, Santa Maria, RS" (2010); “O desenvolvimento rural sustentável como forma de valorização do espaço local: resgatando saberes na Escola Municipal de Ensino Fundamental Bernardino Fernandes, Distrito de Pains, Santa Maria, RS” (2011); "Formação de professores das Escolas do Campo: uma reflexão a partir da Escola do Campo no município de Santa Maria, RS" (2011); "Formação de professores das escolas da reforma agrária no âmbito da 8 Coordenadoria Regional de Educação" (2012); “As dificuldades no processo de inclusão dos alunos das Escolas Itinerantes e dos assentamentos do MST na rede pública do ensino nas cidades de São Gabriel e Santa Margarida do Sul" (2012); "Formação de professores das Escolas do Campo: uma reflexão a partir da Escola do Campo na Região Centro e Oeste do Rio Grande do Sul” (2013); “Educação do Campo em Santa Maria/RS: Educadores, Escolas e Comunidades Rurais" (2013-15); "Formação de professores das escolas do campo: inclusão cidadã e valorização do espaço agrário” (2015-17).

A linha de pesquisa "Dinâmicas Territoriais Rurais" desenvolve projetos nas seguintes temáticas: assentamentos rurais, agricultura familiar e desenvolvimento territorial. São estudadas as dinâmicas e conflitos das territorialidades rurais historicamente produzidas pelo capitalismo, os movimentos de resistência e de luta e as alternativas de desenvolvimento local e territorial que se constituem como possibilidades de permanência das populações e grupos sociais que compõem a diversidade do campo brasileiro.

Investigam-se a pobreza rural, as condições do trabalho e emprego, as atividades produtivas agrícolas e não agrícolas desenvolvidas pelos sujeitos do campo em tempos de globalização. Nesses projetos, objetiva-se refletir sobre o aprofundamento do quadro de pobreza, no bojo das transformaçóes em curso 
no meio rural brasileiro, e sobre a mudança de significado do espaço rural, tendo-se por base o movimento de expansão do capitalismo urbano-industrial na agricultura e no rural como um todo, como parte do processo de mundialização.

São exemplos de projetos guarda-chuva, desenvolvidos nessa linha de pesquisa:

- "Estratégias de reprodução familiar em assentamentos: limites e possibilidades para o desenvolvimento rural" (2005-10). Tem por objetivo analisar o processo de formação e territorialização dos assentamentos rurais no Rio Grande do Sul, focalizando os processos de luta pela terra e as possibilidades, atividades e práticas de permanência no campo das famílias assentadas, assim como suas relações com as sociedades envolventes, pois a luta dos assentados não se esgota com a conquista da terra, mas continua no sentido de promover as condições necessárias à produção agrícola, valorizando o espaço rural, promovendo o desenvolvimento da região onde estão inseridos. Os assentamentos rurais têm possibilitado aos agricultores familiares que neles vivem um espaço de produção de alimentos para o autoconsumo e comercialização, gerando trabalho e renda, proporcionando condições de moradia, de trabalho e de vida digna, o que não significa que todas as carências venham sendo supridas; pelo contrário, o quadro de pobreza ainda persiste, e muitos direitos ainda não foram conquistados;

- "Reforma agrária e assentamentos no Brasil: o caso dos assentamentos de reforma agrária no Rio Grande do Sul” (2010-15). Esse projeto tem como objetivo descrever e interpretar os condicionantes históricos, sociais e econômicos da ocupação do espaço pelos assentamentos de reforma agrária e os impactos socioterritoriais resultantes desse processo. Os resultados das pesquisas apontam problemas estruturais vigentes desde o momento de sua implantação, passando pela falta de assistência e educação técnica e a falta de participação de instituições, como problemas na limitação dos mercados para comercialização dos produtos. Observam-se, por outro lado, impactos sociais e econômicos positivos no que se refere à participação na economia municipal, à melhora significativa da qualidade de vida das famílias assentadas e à enorme satisfação pela conquista da terra; 
- “Agricultura familiar e políticas públicas para o campo" (2012-16). Analisa as condições e características da agricultura familiar no Rio Grande do Sul, seu significado para a economia e a sociedade regional, assim como o papel das políticas públicas para o setor. Busca compreender as especificidades do espaço rural gaúcho sob a globalização da economia e a eficácia das políticas públicas e seus impactos espaciais.

Cabe destacar que esses projetos só puderam ser desenvolvidos a partir do financiamento das instituições de fomento, por meio, seja da concessão de bolsas para os estudantes, seja de recursos financeiros para o custeio das pesquisas e investimentos em equipamentos e outros recursos dos laboratórios. Os estudantes receberam, nas várias edições dos projetos de pesquisa e extensão, bolsas dos seguintes órgãos: Fipe/UFSM, Fiex/UFSM, Prolicen/ UFSM, ProExt/MEC, PIBIC/CNPq e Probic/FAPERGS. Os recursos de custeio e investimento vieram a partir dos seguintes editais de financiamento: ProExt/MEC, Edital Universal/CNPq, Edital Ciências Humanas/CNPq, Programa Pesquisador Gaúcho/FAPERGS, além dos recursos institucionais da UFSM, viabilizados pelo Departamento de Geociências, Centro de Ciências Naturais e Exatas e Programa de Pós-Graduação em Geografia.

A interlocução com a sociedade não se faz apenas nos projetos de pesquisa e extensão, ela está presente também nos eventos que o GPET promove, buscando cumprir seu compromisso com a democratização e a popularização da ciência e do conhecimento. Os eventos objetivam também partilhar o que é produzido com os colegas pesquisadores de outras instituições, formando redes colaborativas de troca de experiências, saberes, práticas e metodologias, além de promover momentos de socialização e afetividade entre pesquisadores, professores e estudantes de diferentes centros de pesquisa e regiões do país. Ao longo de sua trajetória acadêmica, o GPET promoveu os seguintes eventos:

- Educação do Campo e Valorização do Espaço Agrário (2007) - seminário de formação continuada para educadores das escolas do campo, abrangendo mais de 23 municípios do estado;

- Formação Continuada de Educadores da Reforma Agrária (2009) - reuniu 450 educadores de acampamentos e assentamentos do Rio Grande do Sul; 
- V Encontro de Grupo de Pesquisa Agricultura, Desenvolvimento e Transformações Socioespaciais (2009) - teve como tema "Olhares sobre o processo investigativo", objetivando refletir sobre os caminhos metodológicos já percorridos e articular projetos conjuntos entre os grupos de pesquisa participantes. Foram apresentados, nessa ocasião, quase cem trabalhos de pesquisa agrupados nos seguintes eixos temáticos: dinâmicas do espaço rural contemporâneo, dinâmicas do espaço urbano, turismo e pluriatividade, educação do campo e reflexões sobre a pesquisa e a extensão, políticas públicas e desenvolvimento, relações campo-cidade, e comunidades e populações tradicionais;

- I Seminário Regional de Educação do Campo (2013) - objetivou discutir experiências, práticas e metodologias de Educação do Campo entre educadores em atividade na região central do estado do Rio Grande do Sul, visando à preparação do evento nacional, promovido no ano seguinte, também realizado no município de Santa Maria;

- II Seminário Internacional de Educação do Campo e Fórum Regional do Centro e Sul do Rio Grande do Sul (2014) - teve como tema: educação, memória e resistência popular na formação social da América Latina.

Esses eventos de maior abrangência são complementados por eventos de menor envergadura, mas que oportunizam o estudo, a reflexão e o debate entre os integrantes do grupo, sobretudo alunos de pós-graduação, com pesquisadores e estudantes de outras áreas do conhecimento e/ou outros grupos de pesquisa. São seminários que ocorrem ao longo do ano letivo, articulados por um tema ou assunto que compóem os projetos em desenvolvimento. Esses eventos menores tornam-se significativos para a formação dos estudantes por oportunizar o estudo e a experiência na redação de textos e apresentação oral de trabalhos científicos. Em 2007, realizaram o I Ciclo de Estudos - a questão agrária brasileira - e, em 2017, o II Ciclo de Estudos Saberes Tradicionais - as expressões artesanais do rural.

Além desses eventos promovidos pelo grupo, seus integrantes apoiam e participam de diversos outros, colaborando e auxiliando na organização, a fim de estreitar laços de solidariedade com outros grupos da instituição.

Nesse percurso formativo, assume especial relevo a escrita científica, como forma de partilha, socialização e popularização do que é feito na academia, especialmente os frutos de sua reflexão teórico-metodológica, que compõe 
sua produção científica. Todos os projetos desenvolvidos encerram com a produção de um relatório que contempla todas as atividades realizadas, escrito pelos estudantes e professores, sob a supervisão destes últimos. Tais relatórios, por fim, resultam em textos publicados na forma de artigos científicos, em diversos periódicos e capítulos de coletâneas nas áreas da Educação e da Geografia principalmente. Entre as publicações do GPET, merecem destaque:

- Espaços-tempos de itinerância:interlocuções entre universidade e escola itinerante do MST. Orgs.: Ane Carine Meurer e Cesar DE David. Santa Maria: Editora UFSM, 2006;

- Experiências e diálogos em educação do campo. Orgs.: Kelma Socorro Alves Lopes de Matos, Carmen Rejane Flores Wizniewsky, Ane Carine Meurer e Cesar DE David. Fortaleza: Edições UFC, 2010;

- "Palmas" para o quilombo: processos de territorialidade e etnicidade negra. Orgs.: Ana Lúcia Aguiar Melo, Cesar DE David, Dilmar Luiz Lopes, Cristiano Sobroza Monteiro, José Luiz de Moura Filho, Raoni da Rosa e Rosane Aparecida Rubert. Santa Maria: Editora UFSM, 2011;

- Rio Grande do Sul: estudos de geografia agrária. Orgs.: Cesar DE David, Carmen Rejane Flores Wizniewsky e Janete Webler Cancelier.Porto Alegre: Evangraf, 2015;

- Agricultura e transformações socioespaciais: olhares geográficos e a pesquisa de campo. Orgs.: Cesar DE David e Carmen Rejane Flores Wizniewsky. Porto Alegre: Evangraf, 2015;

- Educação, memória e resistência popular na formação social da América Latina. Orgs.: Carmen Rejane Flores Wizniewsky e Leonice Aparecida de Fátima Alves Mourad. Porto Alegre: Evangraf, 2016.

Os trabalhos acadêmicos são também significativos na formação dos educadores, seja na formação inicial, seja na pós-graduação. Os estudantes que compõem o GPET se envolvem na elaboração, e os professores, na orientação e supervisão de trabalhos de conclusão de curso, estágios supervisionados, dissertações de mestrado e teses de doutorado.

O Grupo de Pesquisa em Educação e Território vem, ao longo de sua trajetória, promovendo e ampliando os estudos e pesquisas referentes às temáticas que envolvem a educação do campo e as territorialidades rurais contemporâneas em suas mais diversas abordagens. Esse interesse também surge 
nos acadêmicos comprometidos com a realidade ainda desigual do campo e da educação, com relação à superação do quadro de pobreza e concentração que persiste no espaço rural gaúcho, brasileiro e latino-americano. Seu percurso é marcado pelo enraizamento nos territórios rurais, analisando e sistematizando trajetórias de camponeses, agricultores familiares, pescadores, assentados, cooperativados, populações tradicionais e demais grupos que compóem a diversidade dos povos do campo, bem como pelas trajetórias de educadores e educandos das escolas do campo, também diversas e plurais, a exemplo da universidade e suas possibilidades de formação. Assim, a práxis em um ambiente universitário somente pode vir a se realizar mediante um processo de inserção/aproximação com as diferentes realidades educacionais e sua necessária discussão/reflexão.

\section{Considerações finais}

A universidade é espaço-tempo de formação de educadores que, não apenas por meio do currículo formal, desenvolvem estratégias de aprendizagem diferenciadas, seja via participação em projetos de pesquisa, extensão e ensino, seja via interação e troca de saberes com as comunidades e com os demais estudantes e pesquisadores. Nos grupos de pesquisa, vivenciam-se experiências e práticas que contribuem para a formação de sujeitos históricos e políticos comprometidos com as transformações sociais e com a produção do conhecimento, buscando-se sua universalização. A partir dessas premissas, o Grupo de Pesquisa em Educação e Território buscou oportunizar experiências junto às escolas do campo e demais espaços formativos formais e não formais, constituindo-se lócus de educação popular em que o direito ao acesso à educação diferenciada se efetiva. Pretende-se, com isso, compreender as problemáticas relacionadas à terra e à escola, que, com seu projeto político-pedagógico, poderá vir ao encontro desses interesses.

As experiências vivenciadas junto aos espaços formativos do campo, escolares e não escolares, possibilitaram aprendizagens a todos os participantes. Essas reflexões remetem-se a compreender o quanto a universidade ainda tem se mantido como instituição que se desvincula do direito à educação, por meio tanto de uma educação alijada da realidade das classes trabalhadoras quanto de projetos que não procuram problematizá-la, compreendê-la. 
Portanto, muito ainda temos que trabalhar no sentido de transformar essa instituição em espaço-tempo que se articula à educação popular, independentemente do nível de ensino. Sendo assim, opta-se por trabalhar na perspectiva de formar trabalhadores em educação comprometidos com essas realidades. Com esses projetos político-pedagógicos, já fazemos algo, superando, assim, a educação que vem sendo desenvolvida nos vários espaços-tempos. Com tais compromissos, acredita-se que o direito à educação terá mais possibilidade de efetivar-se.

As ações desenvolvidas pelo Grupo de Pesquisa em Educação e Território buscam um educando-leitor-investigador consciente da produção do espaço e de sua representação. Nesse sentido, a representação do espaço geográfico é muito importante para que os educandos compreendam fenômenos e processos históricos e sociais. Assim, o professor de Geografia tem um papel fundamental, enquanto mediador e problematizador, estimulando o educando a realizar a sua leitura do mundo e traçar suas formas de intervenção, contribuindo de forma significativa para a sua autonomia, inclusive de sua própria aprendizagem e formação.

\section{Referências}

DE DAVID, Cesar e WIZNIEWSKY, Carmen Rejane Flores (orgs.). Agricultura e transformações socioespaciais: olhares geográficos e a pesquisa de campo. Porto Alegre: Evangraf, 2015.

FREIRE, Paulo. Pedagogia da autonomia. 17 ed. Rio de Janeiro: Paz e Terra, 2002.

MATOS, Kelma Socorro Alves Lopes de et al. (orgs.). Experiências e diálogos em educação do campo. Fortaleza: Edições UFC, 2010.

MELO, Ana Lúcia Aguiar et al. "Palmas" para o quilombo: processos de territorialidade e etnicidade negra. Santa Maria: Editora UFSM, 2011.

MEURER, Ane Carine e DE DAVID, Cesar (orgs.). Espaços-tempos de itinerância: interlocuçôes entre universidade e escola itinerante do MST. Santa Maria: Editora UFSM, 2006. 
SILVA, Ana Maria Radaelli da. "Trabalho de campo: prática "andante” de fazer Geografia”. In Geo UERJ: Revista do Departamento de Geografia. n.11, pp. 61-73, 2002.

WIZNIEWSKY, Carmen Rejane Flores e MOURAD, Leonice Aparecida de Fátima Alves (orgs.). Educação, memória e resistência popular na formação social da América Latina. Porto Alegre: Evangraf, 2016.

et al. (orgs.). Rio Grande do Sul: estudos de geografia agrária. Porto Alegre: Evangraf, 2015. 


\title{
Aprendizagem cooperativa no ensino superior
}

\author{
Uma discussão pertinente
}

\author{
Marinez Cargnin-Stieler \\ Marcus Vinícius Araújo Damasceno
}

\section{Introdução}

Este trabalho é um recorte de um programa mais amplo e tem por objetivo contribuir com as discussões sobre aprendizagem e intensificar as trocas de saberes relacionadas à formação de cidadãos conscientes e integrados à sociedade. Discorre sobre a Aprendizagem Cooperativa (AC) no curso de Engenharia Civil, no campus Prof. Eugênio Carlos Stieler, da Universidade do Estado de Mato Grosso (UNEMAT).

Analisar um trabalho realizado por diversas pessoas não é uma tarefa fácil de mensurar e quantificar; no entanto, pretende-se discutir e relatar algumas questões, como as principais mudanças encontradas no curso de Engenharia Civil após quatro anos de envolvimento com a AC.

Inicialmente, discutem-se as implicações para a Engenharia Civil, no entanto, pode ser mais abrangente: como maximizar a aprendizagem dos estudantes e formá-los para que sejam capazes de cooperar e estabelecer relações interpessoais positivas? Quais os avanços na AC na UNEMAT?

\section{Aprendizagem cooperativa}

As aprendizagens que envolvem os estudantes ativamente estão desenhadas como aprendizagem ativa, definida como método de ensino que envolve os estudantes no processo de aprendizagem (Prince, 2004). Dentre as apren- 
dizagens ativas, citam-se: aprendizagem baseada em problemas e em projetos (problem \& project-based learning); aprendizagem entre pares (peer instruction); pense-par-compartilhe (think-pair-share); grupos resolvendo exercícios em sala de aula (in-class exercise teams); tomando notas cooperativamente em pares (cooperative note-taking pairs); questionamento guiado entre pares (guided reciprocal peer questioning); resolução em voz alta de problemas em pares (thinking-aloud pair problem-solving), entre outras (Villas-Boas, 2012).

A AC constitui um método de aprendizagem que, ao desenvolver competências sociais, possibilita aos estudantes aprender e, assim, contribuir para a formação de sujeitos integrados em uma sociedade democrática e da informação (Pinho et al., 2013). A AC, no ensino superior, pode ser considerada uma metodologia de ensino que possui fundamentação teórica capaz de desenvolver nos estudantes, durante sua formação, aspectos diferenciados, como habilidades sociais e inteligência emocional, consideradas facilitadores das relações sociais. A AC pode complementar o modelo educacional tradicional, baseado em aspectos racionais, por potencializar possibilidades de preparar cidadãos solidários, que respeitam as diferenças, com autoestima elevada, capazes de liderar em equipes de forma positiva e com habilidades cooperativas (Vasconcelos et al., 2007).

Em grupos cooperativos, ocorre troca de informações - interdependência positiva -, discutem-se ideias, criam-se o espírito de equipe e a cooperação entre as pessoas do grupo.

Este trabalho está focado nos grupos cooperativos informais - alunos que se reúnem para estudar conteúdos com o intuito de obter a aprovação e concluir o curso.

Segundo Johnson e Johnson (1994) e Firmiano (2011), para que o trabalho cooperativo seja eficiente e produtivo no ensino-aprendizagem, são necessários: interdependência positiva; responsabilidade individual; interação face a face; habilidades interpessoais; e processamento grupal, consideradas as principais características de grupos cooperativos (Freitas e Freitas, 2003; Johnson et al., 1999; Slavin, 1988).

As principais vantagens para utilizar-se da AC: aumento no rendimento acadêmico, ganho na autoestima dos alunos, melhoria das suas competências sociais (Pinho et al., 2013). Nesse sentido, na AC, além do conhecimento adquirido e compartilhado, os alunos envolvidos desenvolvem habilidades interpessoais que vão além da vida acadêmica (Teixeira e Reis, 2012). Entretanto, também é possível citar algumas dificuldades para sua implementação 
em sala de aula: demanda de tempo, demanda de recursos, individualismo e extensão dos programas de ensino (Pinho et al., 2013).

$\mathrm{Na} \mathrm{AC}$, as células são, em geral, compostas por pessoas heterogêneas com diferentes habilidades. Isso permite a troca de saberes, aumentando o compartilhamento de ideias entre os envolvidos no processo de aprendizagem (Millis e Cottell Jr., 1998). Para que os alunos tenham sucesso dentro do grupo, uma consideração cuidadosa em relação à heterogeneidade do coletivo precisa ser dada em conjunto com papéis que asseguram a participação ativa e igualitária de todos os alunos (Pinho et al., 2013). Nesse contexto, há uma interação mais próxima entre os membros, e não há a figura do detentor do conhecimento, pois todos os participantes têm igual importância para a construção do conhecimento. Portanto, além do saber acadêmico, fortalecimento das relações interpessoais e o desenvolvimento de habilidades sociais que vão além da vida acadêmica, tem-se o sentimento de pertencimento ao espaço estudantil (Pereira e Sanches, 2013).

\section{Contextualização do estudo}

Em 2012, a UNEMAT implantou o Programa de Formação de Células Cooperativas (FOCCO), que estimula estudantes a atuarem como protagonistas da aprendizagem (UNEMAT, 2012). O programa tem como objetivos aumentar a taxa de permanência e aprovação nos cursos de graduação, estimular a formação de capital social a partir do capital intelectual discente da UNEMAT e formar profissionais competentes, proativos e habilitados para o trabalho em equipe e divulgação da $\mathrm{AC}$ em escolas de educação básica (UNEMAT, 2015).

Entende-se que o objetivo da UNEMAT, como papel importante na formação de uma sociedade democrática, é investir hoje para colher amanhã cidadãos formados e capazes de transformar a sociedade. O recorte inicial é destacar as atividades desenvolvidas no curso de Engenharia Civil, no campus universitário prof. Eugênio Carlos Stieler/UNEMAT. 


\section{Metodologia}

As Células Cooperativas foram implantadas em 2012 no curso de Engenharia Civil. A partir de 2015, ocorreu a intensificação dos trabalhos para o primeiro semestre do curso. Com a finalidade de cativar os alunos ingressantes do curso de Engenharia Civil, é realizada a apresentação do FOCCO durante a acalouração institucional, bem como é reforçado o convite pela coordenação do curso, por professores e pelos articuladores de Célula, além da divulgação de pequenos cartazes nos murais das salas e corredores. Esta pesquisa descreve o estudo de caso de forma qualitativa.

\section{Resultados}

A partir da seleção de 2012 até 2017, o curso de Engenharia Civil contou com a participação de nove bolsistas e oito Células.

Em 2013, o curso contava com duas Células. A Célula "Integrando ideias" foi destinada à disciplina de Cálculo Integral e Diferencial, escolhida devido às dificuldades apresentadas pelos acadêmicos em relação à aprendizagem dos conteúdos abordados em sala de aula e também pelo número de reprovações. O objetivo dessa Célula foi minimizar as reprovações nas disciplinas focadas, favorecer a compreensão dos conteúdos abordados em sala de aula e desenvolver habilidades sociais, entre elas, o trabalho em equipe. Essas Células mudavam de disciplina conforme as dificuldades de aprendizagem dos acadêmicos.

Em 2015/1, foi criada a Célula "Desenho técnico auxiliado por AutoCAD”, com o objetivo de familiarizar e desenvolver as habilidades básicas e necessárias dos celulandos no software AutoCAD, pois a carência desse conhecimento deixava os acadêmicos com dificuldades de aprendizagem ao cursarem algumas disciplinas. Com a seleção de 2015, a forma de convidar os celulandos também foi intensificada. Essa Célula começou com mais de cinquenta celulandos, que formavam um grupo cujas reuniões eram semanais. Foi possível perceber a formação de Células de ACs, o que foi gratificante para os envolvidos. Acadêmicos de outros cursos também tiveram interesse nessa Célula, que sempre teve um número significativo de celulandos. 
A Célula "Empurrão" tinha como objetivo contribuir com o maior índice de cooperativismo entre os acadêmicos do $1^{\circ}$ semestre do curso, em especial a troca de conhecimento entre os celulandos com o intuito de alcançarem juntos objetivos comuns. Percebeu-se que o princípio do cooperativismo surgiu antes mesmo de a Célula se reunir; na sala de aula, a interação com os professores foi um aprendizado cooperativo que ultrapassou o semestre. $\mathrm{O}$ apoio dos professores foi um ponto importante para o sucesso da Célula e para os ganhos. Acredita-se que esse tenha sido um fator importante para a maioria dos alunos da sala participar da Célula.

Quanto à evasão do curso de Engenharia Civil, vale destacar que, no edital de vagas remanescentes de 2017/1, não existe nenhuma vaga até o $5^{\circ}$ semestre. Torna-se evidente, entre outros fatores, o êxito do FOCCO em relação ao seu objetivo de diminuir a evasão, pois, após a sua implantação, o curso apresentou uma taxa de abandono de apenas 3,75\%, índice abaixo da média dos cursos da UNEMAT. Atribui-se também sucesso ao FOCCO dentro do curso de Engenharia Civil de Tangará da Serra.

\section{Considerações finais}

Foi possível perceber a multiplicação da AC no curso tanto pelas Células criadas como pela cooperação entre os alunos, ponto considerado como primordial no entendimento dos autores, pois, se as células cooperativas se multiplicarem, várias dificuldades podem ser sanadas e os cursos, possivelmente, terão menos evasão e reprovação. Os acadêmicos que se destacam na formação de Células serão futuros formadores de novos profissionais.

\section{Referências}

FREITAS, L. V. e FREITAS, C. V. Aprendizagem cooperativa. Porto: Asa, 2003.

FIRMIANO, E. P. Aprendizagem cooperativa na sala de aula. Fortaleza: PRECE - Programa de Educação em Células Cooperativas, 2011

JOHNSON, D. W. e JOHNSON, R. An overview of cooperative learning. J. Thousand, A. Villa and A. Nevin, Brookes Press, Baltimore, pp. 1-21, 1994. 

1999.

et al. El aprendizaje cooperativo en el aula. Buenos Aires: Paidós,

MILLIS, B. J. e COTTELL JR. P. G. Cooperative learning for higher education faculty. Phoenix: Oryx Press, 1998.

PEREIRA, M. e SANCHES, I. "Aprender com a diversidade: as metodologias de aprendizagem cooperativa na sala de aula”. Nuances: Estudos sobre Educação, v. 24, n. 3, pp. 118-39, Presidente Prudente, set.-dez. 2013.

PINHO M. et al. "As opinióes de professores sobre a aprendizagem cooperativa”. Diálogo Educacional, v. 13, n. 40, pp. 913-37, Curitiba, set.dez. 2013.

PRINCE, M. "Does Active Learning work? A review of the research". Journal of Engineering Education, v. 93, n. 3, pp. 223-31, 2004.

SLAVIN, R. E. Student team learning: an overview and practical guide. Washington: National Education Association, 1988.

TEIXEIRA, M. T. e REIS, M. F. "A organização do espaço em sala de aula e as suas implicações na aprendizagem cooperativa”. Meta: Avaliação, v. 4, n.11, pp. 162-87, Rio de Janeiro, maio - ago. 2012.

UNEMAT - Universidade do Estado de Mato Grosso. Edital n. ${ }^{\circ}$ 019/2012 PROEG/UNEMAT: Programa de Formação de Células Cooperativas - FOCCO. Cáceres, 2012. Disponível em: https://goo. gl/5RRPSX. Acesso em: 7 jul. 2017.

. Programa de Formação de Células Cooperativas - FOCCO. Edital $n^{\circ}$ 001/2015 PROEG/UNEMAT. Universidade do Estado de Mato Grosso, Cáceres, 2015.

VASCONCELOS, A. L. F. S. et al. "Uma reflexão da aprendizagem cooperativa como estratégia de ensino para a formação dos contadores”. Revista de Informação Contábil, v. 2, n. 1, pp. 72-83, out.-dez. 2007.

VILLAS-BOAS, V. e MATASSOGLIO NETO, O. "Aprendizagem ativa na educação em Engenharia”. In Simone Leal Schwertl et al. (orgs.). Desafios da educação em Engenharia: vocação, formação, exercício profissional, experiências metodológicas e proposiçôes. Blumenau: EdiFURB, 2012, pp. 59-112. 


\section{Educação escolar quilombola}

\section{Os educadores do território quilombola Vão Grande}

Francisca Edilza B. A. Carvalho Maria Helena Tavares Dias

\section{Introdução}

De acordo com Carvalho (2016, p. 87), “a educação realizada nas comunidades quilombolas passou por um longo período de esquecimento, diluída nas políticas da Educação Rural, sem nenhuma política pública e ou pedagógica que considerasse a sua especificidade". Esse quadro começa a se modificar a partir das lutas tecidas pelos movimentos sociais, por meio de ações que instigaram múltiplas discussões sobre mudanças no modelo de ensino para as escolas das comunidades quilombolas no Brasil.

Assim, "as reivindicações dos movimentos sociais encontraram eco no parlamento e permitiram o resgate de lutas em favor do reconhecimento de direitos" (Leite, 2000, p. 19), culminando na promulgação da Resolução n. ${ }^{\circ}$, de 20 de novembro de 2012, que institui as Diretrizes Curriculares Nacionais para Educação Escolar Quilombola. Para Castilho e Carvalho (2015, p. 6), a publicação dessa legislação pode ser considerada um dos marcos da luta do Movimento Negro e do Movimento Quilombola, pois ela consolida a educação escolar quilombola como uma modalidade de ensino.

Nessa modalidade de ensino, o art. $8^{\circ}$ da Resolução aponta a formação inicial e continuada dos professores como uma das ações para garantir os princípios da educação escolar quilombola. Para Canen e Xavier (2011), a formação continuada de professores constitui papel fundamental, pois prepara o educador para refletir e trabalhar com a diversidade cultural no âmbito escolar e, consequentemente, possibilita a transformação da escola. 
De acordo com Dias (2017), o grande desafio, na atual conjuntura, é avançar na proposição de ações que concatenem os processos e as formas de transmissão de saberes ancestrais das comunidades quilombolas, preservados no cotidiano de vida dos moradores, nos modos de produção de conhecimento, a partir de seu mundo e da sua cultura, aos saberes acadêmicos lecionados no chão das escolas.

Diante desse contexto, a pergunta que permeia o presente artigo é: como está se delineando a formação docente dos educadores que atuam na Escola Estadual José Mariano Bento? Para respondermos a essa questão, os argumentos aqui reunidos foram organizados em cinco partes. A primeira descreve os aspectos metodológicos da pesquisa; a segunda parte apresenta uma breve contextualização do território quilombola Vão Grande e da Escola José Mariano Bento; a terceira apresenta o perfil dos educadores, discute e analisa como está se delineando a formação docente desses educadores; a quarta e última parte tece as considerações finais das ideias e discussões apresentadas no texto.

\section{Metodologia}

A pesquisa de campo e as análises das informações se desenvolveram dentro dos pressupostos da abordagem qualitativa, de cunho etnográfico. Conforme Geertz (2008), a etnografia não é apenas uma questão de método. Embora a prática da etnografia seja estabelecer relações, selecionar informantes, transcrever textos, levantar genealogias, mapear campos, manter um diário, e assim por diante, não são somente essas coisas, as técnicas e os processos determinados, que definem o empreendimento. "O que o define é o tipo de esforço intelectual que ele representa: um risco elaborado para uma 'descrição densa'” (Geertz, 2008, p. 4).

A descrição densa, segundo o autor, é aquela minuciosa, detalhada que permite, por exemplo, diferenciar um tique nervoso de uma piscadela, mas não somente isso, pois demanda um refinamento das lentes observadoras do pesquisador para perceber o elo da significação. Para o autor supracitado, essa descrição densa: 
caracteriza-se na forma como um pesquisador deve descrever seus estudos. O pesquisador deve descrever seu objeto de estudo em suas mais diversas particularidades, levando em conta todos os pequenos fatos que cercam sua vida social. Não bem os fatos em si, mas a ação social destes fatos. Não se busca leis gerais, mas sim significados/significações. A ciência do pesquisador deve ser interpretativa em busca de significado, buscando explicar e interpretar expressões sociais que são 'enigmáticas na sua superfície' (Geertz, 2012, p. 4).

Nesse entendimento, a etnografia nos permitiu a observação e o registro do cotidiano e das experiências vividas pelos educadores, bem como apreensão suas percepções sobre a própria formação inicial e continuada. De acordo com Denzin e Lincoln (2006, p. 19), para validar as informações, o pesquisador etnográfico recorre à triangulação, cruzando as informações, na tentativa de assegurar uma compreensão do fenômeno em questão.

Sobre as técnicas e procedimentos de coletas de dados, além da observação, utilizamos também a entrevista com professores e gestores, com o intuito de conhecermos a perspectiva dos sujeitos. A análise dos dados associou a Análise Etnográfica, proposta por Geertz (2008), às técnicas da Análise de Conteúdo. Para Bardin (1979), é necessário analisar a informação a partir de um roteiro que perpassa pela pré-análise, momento da escolha dos documentos, da formulação das hipóteses e objetivos. A fase seguinte é a exploração do material, na qual se aplicam técnicas específicas segundo os objetivos e há, finalmente, o tratamento dos resultados e interpretações.

\section{Descrição do campo de pesquisa}

O território quilombola Vão Grande está situado no complexo da Serra das Araras, a aproximadamente $80 \mathrm{~km}$ da sede do município de Barra do Bugres-MT e $240 \mathrm{~km}$ da capital de Mato Grosso. É relevante esclarecer que "Vão Grande" ou "território quilombola Vão Grande" é a região geográfica que congrega cinco comunidades: Baixio, Camarinha, Morro Redondo, Vaca Morta e Retiro. É assim conhecida tanto pelos moradores da comunidade quanto pela comunidade externa. A última expressão, entretanto, passou a ser mais usada após o início dos processos de certificação das terras que compõem a região, pela Fundação Palmares (Carvalho, 2016, p. 31). 
Em sua maioria, as casas são construídas de pau a pique, com paredes de barro e cobertas de palha de Indaiá, pois, segundo eles, são as que conservam o interior das casas por mais tempo. A maioria dos homens com mais de 50 anos jamais se sentou em um banco de escola, porém alguns fazem medições de terras como se fossem professores de matemática. "É incrível como através dos tempos, continuam passando esses saberes para seus filhos e familiares" (Dias, 2017, p. 56).

Segundo Carvalho (2016, p. 50), “a região tem uma das mais lindas belezas cênicas do Estado, conserva intactos cânions, grutas, rios, nascentes, e plantas nativas". Por todo o caminho, no período da seca, as árvores se despem, como em um ritual, preparando-se para oferecer, em tempo vindouro, o grande espetáculo das flores, desenhando um cenário multicor que adorna as casas e torna o dueto das serras ainda mais belo (Carvalho, 2016).

De acordo com Dias (2017, p. 56), os moradores dessa região possuem um linguajar próprio, um jeito peculiar de cumprimentar os mais velhos que não se observa em outros lugares. Ainda preservam seus costumes como nas manifestações culturais e religiosas. Seus artesanatos e comidas típicas continuam bem presentes nas comunidades. Lendas, contos, mitos e histórias ainda permeiam o imaginário de muitos, principalmente quando contadas pelos mais velhos em rodas de conversa.

A Escola Estadual José Mariano Bento está localizada na comunidade Baixio e atende a estudantes das cinco comunidades: Baixio, Camarinha, Vaca Morta, Morro Redondo e Retiro. Segundo Carvalho (2016, p. 97), desde que a escola começou a receber os educandos das demais comunidades, por meio da nucleação escolar, ela vem se constituindo como centro político, cultural e educacional do território quilombola Vão Grande.

O nome da escola é uma homenagem, como esclarece o seu projeto político-pedagógico: "A escolha do nome José Mariano Bento se justifica pelo mesmo ser o fundador da Comunidade Quilombola Baixio, os moradores desta comunidade são seus filhos, netos e sobrinhos" (2010, p. 2).

A escola foi criada em 22 de fevereiro de 2010, pelo Decreto n. ${ }^{\circ} 2.378$. No mesmo ano, teve início o processo para construção do prédio escolar, cuja obra não foi concluída "devido às investigações de desvio de verbas de licitações” (Dias, 2017 p. 47).

As aulas são ministradas no prédio inconcluso que conta com oito salas de aula, um refeitório, uma cozinha, banheiros feminino e masculino, diretoria, secretaria, sala dos professores e uma quadra poliesportiva. De acordo com 
Carvalho (2016, p. 98), o prédio inconcluso ainda não conta com iluminação - a instalação elétrica é improvisada. A instalação hidráulica não foi feita, de modo que, para utilizar os banheiros, foi disposto um tambor com água, de onde se retira água com ajuda de um regador e se efetua a descarga dos sanitários; devido à falta dessa instalação, também não é possível utilizar os bebedouros; para manter a água fria, utilizam-se duas garrafas térmicas.

O sistema de ensino na escola é o multisseriado. Tal sistema é regulamentado pelas Diretrizes Complementares, Normas e Princípios para o desenvolvimento de políticas públicas de atendimento da Educação Básica do Campo. Assim está escrito na legislação em relação ao funcionamento das salas multisseriadas (art. 10, $\$ 2^{\circ}$ ):

As escolas multisseriadas, para atingirem o padrão de qualidade definido em nível nacional, necessitam de professores com formação pedagógica, inicial e continuada, instalações físicas e equipamentos adequados, livros e materiais didáticos apropriados e supervisão pedagógica permanente (Parecer CNE/CEB, p. 12, n²3/2007).

No entanto, no chão da Escola José Mariano Bento, a situação é bem diferente: faltam formação pedagógica, instalações físicas e equipamentos adequados, livros e materiais didáticos que os habilitem a planejar e ministrar aulas, para várias turmas ao mesmo tempo. Segundo Carvalho (2016, p. 121), "A falta de formação para ministrar aulas neste sistema de ensino se constitui uma das maiores queixas dos educadores, em relação às condições de trabalho".

O Parecer das Diretrizes Curriculares para Educação Escolar Quilombola reconhece que a ausência de formação é uma realidade nacional: "houve a reivindicação do direito à formação dos professores que atuam em instituições escolares ainda organizadas dessa maneira" (CNE/CEB, p. 38, no 16/2012). De acordo com Castilho (2011, p. 154), "esse sistema de ensino ainda é uma realidade frequente nas diversas regiões periféricas urbanas, mais acentuadamente nas regióes rurais do Brasil". Essa realidade também é um aspecto que irmana os povos quilombolas, indígenas e do campo (Carvalho, 2016). 


\section{Os educadores da Escola José Mariano Bento}

Segundo Carvalho (2016, p. ), o quadro de profissionais da educação que atua na escola é formado por 19 pessoas, das quais 11 integram o corpo docente, que inclui uma diretora, uma coordenadora e nove professores, sendo quatro deles quilombolas e oito urbanos. Oito integram o quadro dos educadores não docentes, que inclui uma secretária, três vigias, duas zeladoras e duas merendeiras, sendo todos quilombolas.

Cabe esclarecer que, dos 19 profissionais que atuam na Escola José Mariano Bento, 11 são quilombolas, atendendo ao que está disposto nas Diretrizes Curriculares Nacionais para Educação Escolar Quilombola. É importante ver o que diz a Resolução n. ${ }^{\circ}$ 8, de 20 de novembro de 2012:

Art. 8, [...] IV - presença preferencial de professores e gestores quilombolas nas escolas quilombolas e nas escolas que recebem estudantes oriundos de territórios quilombolas;

Art. $39, \S 2^{\circ} \mathrm{A}$ gestão das escolas quilombolas deverá ser realizada, preferencialmente, por quilombolas [...]

Art. 48 A Educação Escolar Quilombola deverá ser conduzida, preferencialmente, por professores pertencentes às comunidades quilombolas.

Já a Conferência Nacional de Educação diz "h) Assegurar que a atividade docente nas escolas quilombolas seja exercida preferencialmente por professores/as oriundos/as das comunidades quilombolas" (Conae, 2010, pp. 131-2).

O Plano Nacional de Educação afirma "12.13. Expandir atendimento específico a populações do campo e comunidades indígenas e quilombolas, em relação a acesso, permanência, conclusão e formação de profissionais para atuação nessas populações" (PNE, 2014, p. 73).

No entanto, a legislação ainda está longe de se efetivar. O momento de atribuição de aulas e demais cargos gera muitos confrontos, disputas e desafetos, dividindo o corpo docente e interferindo diretamente nas relações que se estabelecem no seio da escola. Cabe aos órgãos competentes fazer valer a lei e implementá-la.

Todos os educadores são remunerados pelo estado e contratados temporariamente. Os contratos são efetuados no início do mês de fevereiro e se encerram em meados do mês de dezembro. Não há nenhuma garantia de que 
o funcionário será contratado no ano seguinte ou de que ele permanecerá até o final do ano, pois o vínculo pode se extinguir caso a escola receba um profissional efetivo, concursado.

Essa é uma realidade enfrentada por muitos profissionais da educação em todo o estado de Mato Grosso, de modo que, quando se aproxima o final do ano, as preocupações se agravam. A vida dentro do "contrato" é desumana, gera insegurança e instabilidade. Uma das bandeiras de luta dos movimentos sociais é a realização de concursos públicos específicos para as comunidades do campo, quer sejam quilombolas, indígenas ou do próprio campo.

Segundo Carvalho (2016, p. 91), a realização de concurso público específico para escolas quilombolas consta entre as reinvindicações apresentadas pela comunidade do território quilombola Vão Grande durante a realização das audiências públicas, organizadas por intermédio do Conselho Estadual de Educação (CEE-MT) no ano de 2015, a fim de discutir a Educação Escolar Quilombola em todo o estado de Mato Grosso.

As demandas por eles apresentadas revelaram a consciência que as comunidades quilombolas têm de sua história, seus anseios pela escolarização dos filhos e ainda a compreensão que têm de que as condições de trabalho e a formação dos profissionais da escola estão intimamente relacionadas ao sucesso ou ao insucesso escolar.

O corpo docente é constituído por 11 educadores: sete moram na cidade de Barra do Bugres, e quatro no território quilombola Vão Grande, sendo três desses na comunidade Baixio e uma na comunidade Morro Redondo.

Quanto à identidade racial, Carvalho (2016) afirma que as quatro educadoras moradoras da comunidade se identificam como negras e quilombolas, e os educadores que moram na cidade de Barra do Bugres se declaram negros.

Em relação à formação inicial, a autora supracitada desvela que os 11 docentes possuem licenciatura plena, a maioria realizada em Pedagogia. O nível de escolarização está constituído por cinco graduados, cinco especialistas e uma mestra em educação. De acordo com Carvalho (2016, p. 35), a inserção da professora quilombola no programa de mestrado da Universidade Federal do Mato Grosso ressignifica as possibilidades de acesso e proporciona uma nova compreensão sobre a pesquisa nas comunidades:

Ao adentrar nos Programas de Pós-Graduação, seja em nível de Mestrado, tal como o fez Maria Helena Tavares (UFMT) do Território 
Quilombola Vão Grande; Jair Pereira da Cruz (UNEMAT) e Deiziane Araújo da Silva (UNEMAT) ambos do assentamento Antônio Conselheiro, seja em nível de Doutorado tal como o fez Eliane Boroponepá Monzilar (UNB) da aldeia Umutina, trazem para as suas respectivas comunidades uma ressignificação das possibilidades de acesso, e uma nova compreensão sobre a pesquisa nas comunidades. Traduzindo discursos antigos de que a universidade e as comunidades precisam caminhar lado a lado. Nesses momentos, nessas parcerias, é possível afirmar que a comunidade ressignifica seu lugar em relação à Pesquisa Acadêmica. Já não é a Universidade falando sobre as comunidades. São as comunidades falando com/para a universidade.

Para acessar o Ensino Superior, foi ou é necessário investir recursos próprios. Entre os 11 educadores, apenas três cursaram o ensino presencial, oito cursaram a graduação na modalidade a distância, cinco cursaram a graduação em universidade públicas e seis em universidades privadas. "O quadro docente da Escola José Mariano Bento se diferencia de muitas escolas quilombolas do país, apresentando um corpo docente, em que cem por cento dos profissionais são graduados" (Carvalho, 2016, p. 104), embora seja importante adensar que esse quadro é recente e até pouco tempo a graduação era um sonho que parecia inalcançável.

Quanto ao tempo de atuação na comunidade escolar, 80\% dos educadores trabalham na escola há mais de quatro anos, o que pode contribuir para criar laços de afetividade e também para que os educadores conheçam a história, a realidade dos educandos. Para Carvalho (2016), a baixa rotatividade é um aspecto positivo para o desenvolvimento de projetos pedagógicos e outras atividades escolares.

A formação continuada dos educadores da Escola José Mariano Bento ocorre por meio de cursos realizados pela Secretaria Estadual de Educação. Servem como exemplo os cursos específicos para a educação escolar quilombola, que são realizados pela Secretaria Estadual de Educação, por meio da Gerência de Diversidade, em parceria com o Núcleo de Estudos de Pesquisas sobre Relações Raciais e Educação da Universidade Federal de Mato Grosso (NEPRE/UFMT), durante os anos 2014 e 2015. Em relação à realização desses cursos, os educadores reclamam do reduzido número de vagas.

A formação continuada também é realizada por cursos oferecidos pelo Centro de Formação e Atualização dos Profissionais da Educação Básica 
(Cefapro); como exemplo, o curso de Pedagogia de Alternância, solicitado pela Escola José Mariano Bento à formadora do Cefapro, Hellen Cristina de Souza, e realizado entre maio de 2013 e maio de 2014, cujo objetivo era conhecer como se dá a organização do sistema de alternância.

O diferencial desse curso e de outros elaborados nos moldes dessa proposta é o fato de a comunidade participar da sua proposta, organização e coordenação. Para Arroyo (2007, p. 6), “os movimentos sociais não apenas reivindicam ser beneficiários de direitos, mas ser sujeitos, agentes históricos da construção dos direitos". Também cabe ao Cefapro a proposição e acompanhamento da "Sala do educador", que se constitui outro espaço de formação dos educadores. De acordo com Dias (2017), a formação docente contribui para enriquecer as práticas docentes e empoderar os educadores.

A maioria dos professores trabalha 30 horas-aulas, sendo dez delas destinadas à hora-atividade. As horas-atividade são realizadas na própria escola no período vespertino. Para tanto, o horário das aulas foi planejado considerando-se que a cada dia da semana tem um ou mais professores que não retornam para a cidade, pois ficam no alojamento para cumprir a horaatividade e lecionar no período noturno.

De acordo com Carvalho (2016), entre os educadores que moram na cidade e ficam na escola durante a semana, as reivindicações mais recorrentes observadas durante a pesquisa de campo estão relacionadas à estadia, ao alojamento, ao transporte e à alimentação, cujas condições, segundo eles, prejudicam a autoestima do profissional, funcionando como desestímulo à prática docente. Apesar de a Resolução n. ${ }^{\circ}$ 8, de 20 de novembro de 2012, que dispóe sobre as Diretrizes Curriculares Nacionais para a Educação Escolar Quilombola, afirmar o direito à estadia, ao alojamento, ao transporte e à alimentação, existem poucas ou nenhuma aplicabilidade da resolução nesse aspecto.

Os educadores utilizam uma das salas da escola antiga como dormitório; nele, são distribuídas quatro camas, três de solteiro e uma de casal. O "quarto" também tem uma prateleira onde são guardados livros e outros materiais pedagógicos utilizados no planejamento das aulas. Fica localizado entre duas salas de aula, nas quais são ministradas aulas para os adultos, enquanto, concomitantemente, os docentes que não estão ministrando aula "descansam". O mobiliário é de propriedade dos educadores.

A alimentação é feita em um pequeno cômodo, utilizado como cozinha. Nele, há geladeira, fogão, armário e mesa, porém a ausência de água na cozinha dificulta o preparo dos alimentos. Depois que se encerra o período ma- 
tutino das aulas, os educadores se dirigem à cozinha para começar o almoço. A compra do botijão de gás e dos alimentos utilizados é financiada pelos próprios professores.

Entretanto, em relação ao alojamento e à alimentação dos educadores, a Resolução n. ${ }^{\circ} 8$ expõe que:

$\S 1^{\circ}$ Os docentes que atuam na Educação Escolar Quilombola, quando necessário, deverão ter condições adequadas de alojamento, alimentação, material didático e de apoio pedagógico, bem como remuneração prevista na Lei, garantidos pelos sistemas de ensino.

$\S 2^{\circ}$ Os sistemas de ensino podem construir, quando necessário, mediante regime de colaboração, residência docente paraos professores que atuam em escolas quilombolas, localizadas nas áreas rurais, sendo que a distribuição dos encargos didáticos e da sua carga horária de trabalho deverá levar em consideração essa realidade.

Desse modo, as circunstâncias em que vivem os docentes descortinam o abandono no qual trabalham os educadores nas comunidades rurais, demonstrando que, apesar da promulgação dessa Resolução, sua aplicabilidade ainda não alcançou plenamente o sujeito para o qual ela foi elaborada.

\section{Considerações finais}

O objetivo do texto foi tecer reflexões sobre a formação docente dos educadores que atuam na Educação Escolar Quilombola, realizada nas comunidades que integram o território quilombola Vão Grande, localizado no município de Barra do Bugres-MT. A finalidade maior é a de que as problematizações e discussões aqui apresentadas contribuam na elaboração de políticas públicas que possam subsidiar a formação de professores e alicerçar a construção de um projeto de educação que considere suas especificidades históricas, políticas e culturais.

Os dados da pesquisa desvelam que grande parte das angústias vivenciadas pelos professores está relacionada às dificuldades de atender às exigências curriculares da Educação Escolar Quilombola, que abarca as singularidades e as necessidades inscritas nas comunidades, principalmente pelo fato de a escola estar organizada em sistema de ensino multisseriado. 
Esse sistema representa uma das queixas mais recorrentes dos educadores em relação às condições de trabalho. Os educadores destacam a ausência de qualificação, de formação continuada, de instalações físicas e equipamentos adequados, de livros e materiais didáticos que os habilitem a planejar e ministrar aulas para várias turmas ao mesmo tempo.

A implementação da Educação Escolar Quilombola ainda enfrenta outros entraves, quais sejam: escolas estruturalmente precárias, falta de recursos e materiais didáticos contextualizados, precariedade no transporte escolar, merenda escolar insuficiente, falta de concursos públicos específicos, ineficiência das relações de trabalhos, entre outros males.

Ao finalizarmos este artigo, compartilhamos a reflexão de que a oferta de cursos de formação, atualização, extensão, aperfeiçoamento e especialização, presenciais e a distância, tais como os cursos de pós-graduação lato sensu e stricto sensu, específicos para a Educação Escolar Quilombola, contribui significativamente para ressignificar a prática docente. Cursos que realmente atendam às necessidades de formação e qualificação dos educadores e que os qualifiquem para diminuir a distância entre o que se faz e o que se diz.

\section{Referências}

ARROYO, Miguel Gonzáles. Indagações sobre curriculo: educandos e educadores: seus direitos e o currículo. Orgs. Jeanete Beauchamp, Sandra Denise Pagel, Aricélia Ribeiro do Nascimento. Brasília: Ministério da Educação, Secretaria de Educação Básica, 2007.

BARDIN, L. Análise de conteúdo. Lisboa: Edição 70, 1979. 229 p.

BRASIL. Parecer 16/2012 da CEB/CNE - Diretrizes Curriculares Nacionais para a Educação Escolar Quilombola. Brasília, DF.

CANEN, Ana e XAVIER, Giseli P. de M. "Formação continuada de professores para a diversidade cultural: ênfases, silêncios e perspectivas". Revista Brasileira de Educação, v. 16, n. 48, pp. 641-61, Rio de Janeiro, dez. 2011.

CARVALHO, Francisca Edilza Barbosa de Andrade. Educação escolar quilombola na comunidade Baixio - Barra do Bugres/MT: avanços e desafios (dissertação). UFMT, 2016. 
CASTILHO, Suely Dulce de. Quilombo Contemporâneo: educação, familia e culturas. Cuiabá: EdUFMT, 2011.

. "Políticas curriculares para educação quilombola de Mato Grosso: contexto, texto e análise”. In CASALI, Alípio e CASTILHO, Suely Dulce de. Diversidade na educação: implicações curriculares. São Paulo: EDUC, 2016.

e CARVALHO, Francisca E. B. de A. "Educação e quilombo: delineamento dos estudos brasileiros". Quaestio, v. 17, n. 2, pp. 353-69, Sorocaba, nov. 2015.

CNE - Conselho Nacional de Educação. "Diretrizes Curriculares Nacionais para a Educação Escolar Quilombola na Educação Básica”. Resolução CNE/CEB n. ${ }^{\circ}$ 8, de 20 de novembro de 2012. Brasília, Diário Oficial [da] República Federativa do Brasil, 21 de novembro de 2012, Seção 1, p. 26.

DENZIN, Norman K. e LINCOLN, Yvonna S. O planejamento da pesquisa qualitativa: teorias e abordagens. Porto Alegre: Artmed, 2006.

DIAS, Maria Helena Tavares. Entre memórias e narrativas dos festeiros das festas de santo do território quilombola Vão Grande (dissertação). UFMT, 2017.

GEERTZ, Clifford. A interpretação das culturas. Rio de Janeiro: LTC, 2008. . O saber local: novos ensaios em antropologia interpretativa. 10. ed. Petrópolis: Vozes, 2012.

LÜDKE, Menga e ANDRÉ, Marli E. D. A. Pesquisa e educação: abordagens qualitativas. São Paulo: EPU, 1986.

LEITE, Ilka Boaventura. "Os quilombos no Brasil: questões conceituais e normativas”. Etnográfica, v. IV, pp. 333-54, Lisboa, 2000.

MINAYO, Maria Cecília de Souza (Orgs.). Pesquisa social: teoria, método e criatividade. Petrópolis: Vozes, 2007.

MINISTÉRIO DA EDUCAÇÃO. Conferência Nacional da Educação. Documento Final. Brasília, 2010. 
. Plano Nacional de Educação (PNE), Lei no 13.005/2014

“Projeto Político-Pedagógico”. Escola Estadual José Mariano Bento. Barra do Bugres, 2013.

. Parecer CNE/CEB, p. 12, n 23/2007

SILVA, Tomaz T. Documentos de identidade: uma introdução às teorias do currículo. Belo Horizonte: Autêntica, 1999. 


\title{
Financiamento da educação básica no Brasil
}

\author{
Uma discussão necessária
}

Andréia da Silva Mafassioli

\section{Introdução}

O financiamento, como se sabe, é fator decisivo para a execução de toda e qualquer política educacional. Para ampliar o acesso e a permanência dos estudantes com qualidade, é necessária a ampliação dos recursos que hoje temos destinados à educação pública brasileira. Neste texto, apresento uma breve reflexão sobre os elementos do financiamento da educação básica, as fontes de recursos, assim como políticas de alocação e redistribuição de recursos que, ao longo das últimas décadas, têm pautado o financiamento público da educação brasileira, dialogando com pesquisadores desse campo que, insistentemente e com dados consistentes, defendem a ampliação do investimento para melhoria da qualidade da educação pública no Brasil. Não bastam os diagnósticos das avaliações em larga escala e os planejamentos estratégicos propostos nos últimos anos se não houver recursos para colocar as ações planejadas em prática.

\section{Elementos do financiamento da educação básica no Brasil}

As extremas desigualdades sociais e as grandes diferenças entre as regiões do país têm negado o direito à escolarização universal a muitas crianças, adolescentes, jovens e adultos. A histórica escassez de recursos e de investimentos públicos em educação é uma das principais causas dessa situação. Conforme estudo de Davies (2004, p. 51): 
Desde a Independência brasileira, em 1822, até hoje, sempre houve uma grande discrepância entre essas responsabilidades e a disponibilidade de recursos dos governos. O governo central, por exemplo, embora detentor de uma maior parcela das receitas governamentais, nunca assumiu constitucionalmente a obrigação de oferecer educação básica para toda a população, deixando-a a cargo dos Estados e municípios, geralmente menos privilegiados do que ele. O que mais chama atenção nessa questão é a enorme desigualdade de recursos legalmente disponíveis em cada esfera de governo.

Dessa forma, o Brasil tem grandes desafios para garantir o direito de todas as suas crianças e adolescentes à educação pública de qualidade. Ainda estão fora da escola aproximadamente 3,8 milhões de crianças e adolescentes de 4 a 17 anos de idade, faixa etária incluída na educação básica obrigatória do país, que engloba a pré-escola, o ensino fundamental e o ensino médio.

Apenas recentemente, a legislação instituiu a matrícula obrigatória para essa faixa etária: a Lei n. ${ }^{0}$ 12.796/13, que ajustou a Lei de Diretrizes e Bases da Educação Nacional n. ${ }^{\circ}$ 9394/96 à Emenda Constitucional (EC) n. ${ }^{\circ}$ 59, de 11 de novembro de 2009, foi sancionada em 4 de abril de 2013. Municípios e estados tiveram até o ano de 2016 para reestruturar suas redes e oferecer vagas suficientes para atender a crianças e adolescentes da faixa obrigatória de escolaridade que ainda não estão frequentando a escola. O desafio é que, em 2020, quando deve acontecer um novo Censo Demográfico, tenhamos superado essa exclusão escolar.

Além desses desafios na garantia do acesso, temos a luta permanente pela valorização da carreira dos trabalhadores em educação - salários dignos, condições de trabalho, formação adequada - e por melhorias na infraestrutura e nas condições, que influenciam a qualidade do ensino e da aprendizagem ofertados nas escolas públicas.

Tão importante quanto infraestrutura escolar adequada é a garantia de materiais pedagógicos, alimentação, transporte e outros fatores que contribuem para assegurar o acesso, a permanência e o sucesso de estudantes, em especial daqueles que mais precisam do apoio de iniciativas governamentais. Trata-se do provimento de insumos em quantidade e qualidade suficientes para viabilizar os processos de ensino e de aprendizagem.

Nas últimas décadas, o debate sobre o financiamento da educação e sobre a aplicação dos recursos de impostos passou a ocupar um espaço 
central nas discussões acerca das políticas sociais brasileiras. Há tensões entre a destinação de recursos para atender às políticas sociais (educação, saúde, saneamento, habitação, assistência social, salário desemprego etc.) ou atender aos interesses econômicos (subsídios à agricultura, à instalação de fábricas, juros subsidiados, recursos para o salvamento de bancos, renúncia fiscal, etc.).

Um debate mais intenso no campo dos que defendem a educação pública instalou-se, desde o final dos anos 1990, período de formulação do Fundo de Manutenção e Desenvolvimento do Ensino Fundamental e de Valorização do Magistério (Fundef). Nos últimos quatro anos, dentro dos trâmites para proposição e aprovação do novo Plano Nacional de Educação (PNE 2014-24), as disputas nessa arena foram intensas e extensas. Uma das discussões centrais tem sido a necessidade de ampliação dos recursos para ofertar uma educação de qualidade para todos os cidadãos brasileiros.

\section{A trajetória da vinculação constitucional de recursos à educação}

A garantia da educação como um direito está intimamente ligada ao financiamento por parte do poder público. Na história da educação brasileira, a vinculação de recursos acontece somente em períodos ditos democráticos (1934-37, 1946-64, 1983, 1988), e a desvinculação de recursos acontece em períodos autoritários (1937-45, 1964-85), o que, sem dúvida, comprometeu a garantia do direito e da gratuidade da educação (Davies, 2004, p. 35).

Com a retomada democrática, ocorrida na década de 1980, voltaram as vinculações de receita pública; primeiro com a EC n. ${ }^{\circ}$ 24/1983 à Constituição de 1967 e, mais adiante, com sua consagração na Carta Magna de 1988, onde constam os marcos legais básicos do financiamento. A atual CF determinou as vinculações de percentuais da receita de impostos dos governos e estabeleceu também uma contribuição paga pelas empresas, chamada de salário educação, que deve se dirigir obrigatoriamente ao financiamento da educação básica para a manutenção e desenvolvimento do ensino (MDE).

No ano de 2006, por meio da EC 53, o artigo 212 teve duas mudanças no que se refere ao financiamento da educação. A primeira delas definiu que os recursos oriundos da contribuição social do salário educação passariam a ser destinados a toda educação básica pública, não mais apenas ao ensino 
fundamental, como estava determinado pela redação anterior introduzida pela EC 14/1997 (Silva, 2012). A segunda modificação inscreveu no texto constitucional um parâmetro claro para a distribuição das cotas estaduais e municipais do salário educação, qual seja, no número de alunos matriculados nas redes públicas de ensino.

Além desses recursos, a EC n. ${ }^{\circ}$ 59/2009 prevê o estabelecimento de meta de aplicação de recursos públicos em educação como proporção do PIB. Portanto, há uma dupla vinculação de recursos para a educação brasileira impostos e salário educação - e uma referência para o montante de gastos públicos - um percentual do PIB.

Considerando essas modificações, Silva (2012) salienta que as alterações a partir da EC 59/2009 provocaram, com a nova redação, a inscrição de três requisitos fundamentais na $\mathrm{CF}$ ao tratarem da distribuição dos recursos na educação básica - o requisito da universalização, o requisito da garantia de padrão de qualidade e o requisito da equidade (grifo meu).

A receita de impostos de cada ente federado é estabelecida na lei maior, nos artigos 153, 155 e 156. Sobre essa estruturação, Jorge Abrahão de Castro (2005, p. 843) esclarece:

A estrutura de financiamento da educação é fortemente baseada em impostos, que são recursos gerais tomados à sociedade. Isso significa que parcela expressiva dos recursos, principalmente de estados, Distrito Federal e municípios, é proveniente da arrecadação tributária, sobretudo em razão da vinculação de impostos. Essa forma de financiamento para a educação - reserva de determinado porcentual do valor arrecadado mediante impostos - tem sido uma das medidas políticas mais importantes para garantir a disponibilidade de recursos para o cumprimento do vasto rol de responsabilidades do Poder Público nessa área.

Portanto, de acordo com a regra da vinculação de parte da receita resultante de impostos, e considerando todo o sistema de transferências automáticas de impostos entre os entes federados - da União para estados e municípios e dos estados para os respectivos municípios -, da receita efetivamente disponível de cada ente, 18\% (União) ou 25\% (estados e municípios) devem ser alocados à MDE. Essa é a principal fonte de financiamento da educação brasileira. 
Além dessas receitas previstas na CF de 1988, a LDB n. ${ }^{\circ}$ 9.394/1996 indica outras fontes de recursos públicos destinados à educação no artigo 68 :

I - receita de impostos próprios da União, dos Estados, do Distrito Federal e dos Municípios;

II - receita de transferências constitucionais e outras transferências;

III - receita do salário-educação e de outras contribuições sociais;

IV - receita de incentivos fiscais;

$\mathrm{V}$ - outros recursos previstos em lei.

Em 2004, foram introduzidas algumas mudanças no salário educação. Entre elas: desvinculação de $10 \%$ do valor destinado às cotas, que passou a ser destinado a financiamentos de programas geridos pelo Fundo Nacional de Desenvolvimento da Educação (FNDE), ficando o restante para a cota federal (um terço) e estadual e municipal (dois terços); e repasse da cota municipal diretamente pelo FNDE às prefeituras, com base no critério da proporcionalidade do número de alunos matriculados no ensino fundamental, em substituição à sistemática anterior, na qual os valores eram repassados primeiramente para as secretarias estaduais de educação (Castro, 2013).

O montante apropriado pelo governo federal é utilizado para financiar políticas de assistência técnica e financeira, sendo os recursos dirigidos aos caixas de governos estaduais e municipais ou diretamente a escolas públicas e privadas beneficentes.

\section{A organização e as bases do financiamento da educação básica}

Utilizo um conjunto de investigações que tomam o financiamento da educação como política pública que é influenciada pelas políticas educacionais, mas também é "um dos relevantes determinantes do escopo das políticas educacionais praticadas” (Martins, 2010, p. 499). Essa perspectiva de análise também se integra ao grupo de pesquisas que compreende o financiamento, especialmente a partir dos anos 1990, como "importante estratégia para obrigar os países em desenvolvimento ou subdesenvolvidos a adotar modelos de gestão que têm em vista objetivos, definidos pelos organismos internacionais, de alcançar a eficiência e a equidade no setor [educacional]" (Oliveira, 2008, p. 11). 
A compreensão da organização e das bases do financiamento da educação se coloca como uma necessidade para toda a sociedade, devendo envolver, especialmente, os gestores educacionais e toda a comunidade escolar e educacional. Porém, esse entendimento não é tarefa fácil. Conforme destacado por Pinto (2009, p. 2), o financiamento na educação pública:

passa por dois conjuntos de realidades: de um lado, a demanda de estudantes, sujeitos de direitos, a ser atendida; de outro, os recursos disponíveis de tributos, arrecadados, em tese, de toda a população. Em razão da gratuidade da oferta e da multiplicidade de entes federados que oferecem escolas e arrecadam tributos, no momento atual quase a totalidade da receita provém de um complexo cipoal de arrecadações e redistribuições de bilhões de reais por ano e quase a totalidade dos gastos se faz em instituições públicas mantidas pela União, por 26 Estados, pelo Distrito Federal e por 5.564 municípios.

Essa discussão é tarefa complexa, em vista das condições materiais em que o financiamento se efetiva no país, envolvendo os diferentes entes federados - União, estados, Distrito Federal e municípios - e a esfera privada. A organização do sistema educacional brasileiro se caracteriza pela divisão de competências e responsabilidades entre os entes federados, o que se aplica também ao financiamento e à manutenção dos diferentes níveis, etapas e modalidades da educação e do ensino.

As responsabilidades atribuídas para a política pública em educação são balizadas pelo princípio de regime de colaboração entre as instâncias federadas na oferta, na gestão e no financiamento do sistema educacional brasileiro, com a competência de promover a educação pública pela manutenção e expansão dos sistemas de ensino. Tais responsabilidades são atribuídas pela $\mathrm{CF}$ de 1988, e as competências pela LDB de 1996. A CF prevê, no artigo 211, que a União, os estados, o Distrito Federal e os municípios devem organizar em regime de colaboração seus sistemas de ensino. 


\section{0 regime de colaboração no financiamento da educação básica}

A oferta de Educação Básica é, na prática, de responsabilidade dos estados, do Distrito Federal (DF) e dos municípios; entretanto, tal prerrogativa não isenta a atuação da União, por exemplo, no seu financiamento. Nessa dinâmica de financiamento, além dos recursos de impostos e do salário educação, os demais entes federativos ainda recebem transferências de recursos, seja da União, no caso dos estados e do DF, seja da União e dos estados, quando se trata dos municípios. A CF de 1988, ao dispor sobre responsabilidades e prioridades de cada esfera de governo na educação (art. 212), definiu que todos os entes federativos deverão organizar os seus sistemas de ensino em regime de colaboração. Para isso, referendou uma estrutura federativa fundada na cooperação, mas que deixou margem para desvios quanto às responsabilidades. No entanto, esse regime de colaboração foi reformulado pela EC n. ${ }^{\circ}$ 14/96, pela Lei 9.424/96 e confirmado pela LDB de 1996 (Castro e Duarte, 2007), que fixou competências específicas, ao mesmo tempo que manteve a necessidade de cooperação técnica e financeira. Para viabilizar os gastos com esses sistemas, foi estabelecida uma estrutura de financiamento.

A CF e a LDB estabelecem competências e prioridades dos entes federativos em matéria educacional, no que concerne à responsabilidade pelos níveis e etapas da educação escolar, o que repercute diretamente nas prioridades de gastos. Conforme especificado no artigo $211 \mathrm{da} C F$, compete à União organizar o sistema federal de ensino, financiar as instituições públicas federais e exercer as funções redistributiva e supletiva, prestando assistência técnica e financeira aos demais entes federados, decorrentes do modelo de federalismo cooperativo adotado no Brasil. Aos estados e ao Distrito Federal cabe atuar, prioritariamente, no ensino fundamental e médio. Os municípios devem atuar, prioritariamente, no ensino fundamental e na educação infantil.

Assim, conforme argumenta Martins (2009), não é no desempenho de sua função própria que a União descuida do ensino básico. Sua falha é no cumprimento das funções supletiva e redistributiva. Para essas, "deveriam ser abertas novas fontes, recuperadas fontes que foram fragilizadas pelas desvinculações promovidas pela Desvinculação das Receitas da União (DRU), além de serem alocados mais recursos" (Martins, 2009, p. 33). 


\section{A assistência técnica e financeira da união a educação básica}

A União, por meio do MEC, direciona recursos financeiros aos estados, ao Distrito federal, aos municípios e a organizações não governamentais sem fins lucrativos para atendimento à educação básica. O FNDE é o principal responsável pela execução de políticas educacionais de assistência técnica e financeira do MEC aos entes subnacionais e se tornou o maior parceiro dos 26 estados, dos 5.570 municípios e do Distrito Federal no repasse dos recursos para o atendimento à educação básica. De acordo com Farenzena (2011, p. 107):

o bem chamado educação básica luta para se constituir como prioridade nacional, com o concurso das ações de municípios e estados e do suporte de políticas de assistência da União. A sinalização é para políticas universalizantes, com focalizações. Os critérios para o exercício da função redistributiva da União podem ser qualificados como pertinentes diante dos diferentes recortes da desigualdade social e educacional, atentando para as desigualdades de renda, regionais, de etnia/cor, de residência urbana ou rural da população, geracionais.

A referida autora, ao tratar desse tema em outro estudo, argumenta que a assistência é o instrumento que viabiliza o exercício das funções redistributiva e supletiva da União: "O termo 'técnica' significa que os apoios ou suportes são esteados num conhecimento especializado, com base referencial técnico-científica". Também distingue as duas formas de assistência da União na educação aos demais entes federados: a "assistência técnica" ocorre por meio da oferta de programas de formação inicial de professores, programas de capacitação de profissionais ou membros de conselhos da área da educação, disponibilização de ferramentas de planejamento, gestão e monitoramento de políticas e ações e realização de estudos, levantamentos e avaliações. Já a "assistência financeira" ocorre pela transferência de recursos financeiros, tais como o Programa Dinheiro Direto na Escola (PDDE), ou de bens materiais, tais como equipamentos de informática, livros de referência, distribuição de acervos bibliográficos para a educação básica e livros didáticos, entre outros materiais (Farenzena, 2012, p. 108). 


\section{A política de fundos - 0 Fundef e 0 Fundeb}

Em 1998, foi instituído o Fundo de Manutenção e Desenvolvimento do Ensino Fundamental e de Valorização do Magistério (Fundef), aprovado por meio da EC 14/1996 e regulamentado pela Lei n. ${ }^{\circ}$ 9.424/1996. Os interesses que resultaram na criação do Fundef, durante o primeiro governo de Fernando Henrique Cardoso (1995-99), estavam articulados a projetos e programas internacionais de expansão do ensino fundamental, em consonância com as reformas propostas e em detrimento das políticas universalizantes para toda a educação básica.

A implementação do Fundef alterou os pilares do financiamento na educação nacional, por meio da redistribuição dos recursos entre os estados e seus respectivos municípios, de acordo com o número de alunos matriculados em escolas de cada ente federativo. O Fundef foi ancorado na visão de que o Brasil gasta mal os recursos destinados à educação e, portanto, não seria necessário um maior aporte de recursos; a proposta de descentralização propalada pelo fundo resultou na maior responsabilização de estados, Distrito Federal e municípios na composição dos recursos; além disso, estados e municípios tiveram aumentadas as dificuldades e limitações no sentido de ampliar o atendimento a outras etapas e modalidades, entre outros aspectos (Pinto, 2000).

Naquele período, havia muitas críticas referentes ao valor mínimo anual por aluno a ser divulgado pelo governo federal. Alguns pesquisadores, entre eles Monlevade e Ferreira (1998), Davies (1998) e mesmo entidades de classe, argumentaram que, na implementação dessa inovação, o valor aluno/ano não estava adequado ao cálculo estipulado na legislação, o que, nesse caso, prejudicaria os alunos dos estados em que se verificassem necessidades de complementação de recursos, pois poderiam vir a ser insuficientes diante do volume requerido, justamente porque aquele valor aluno/ano estipulado não seria o mais adequado. Os valores divulgados ao longo dos anos foram questionados, pois geraram uma complementação residual da União para estados e munícipios.

De um ponto de vista mais crítico, apontou-se a necessidade de um efetivo compromisso por parte da União, de um mecanismo de financiamento que atendesse a todas as etapas da educação básica e que fosse dotado de instrumentos mais eficazes de transparência e controle social, independentes da instância de poder sobre a qual exercessem fiscalização. 
No contexto do desenvolvimento do Fundef, a Campanha Nacional pelo Direito à Educação propôs, em 2002, o custo-aluno qualidade (CAQ) como uma de suas prioridades (Pinto, 2006). Como forma de mobilização e de pressão sobre os poderes públicos, a entidade optou pela construção de uma proposta de CAQ elaborada por meio de uma metodologia participativa, envolvendo entidades representativas da área da educação, pais e alunos, especialistas, em uma série de oficinas nas quais foram sendo delineados os eixos norteadores (Pinto, 2006, p. 210).

Tendo por referência tanto a legislação educacional brasileira quanto o disposto na CF de 1988, o conceito de CAQ desenvolveu-se a partir de um amplo debate sobre o financiamento da educação e sobre os insumos que deveriam compor uma escola com padrões básicos de qualidade do ensino. A ideia presente nesses estudos foi problematizar e indicar montantes de recursos para se ter um ensino de qualidade (Monlevade, 1997, 1998; Luce e Farenzena, 1999; Pinto, 1999, 2002, 2007; Davies, 2004).

Além dessas críticas, os autores levantam a questão do prejuízo causado pelo Fundef às demais etapas e modalidades da educação básica, como a educação infantil, o ensino médio, a educação de jovens e adultos, educação indígena, do campo e profissional. Bastante recorrente foi a denúncia da distribuição desigual de responsabilidades para com o financiamento do ensino fundamental. Isso indica a fragilidade do exercício de assistência financeira da União no sentido de garantir equidade e qualidade na educação, objetivos estabelecidos na própria Constituição Federal. Ou seja, o poder de intervenção do órgão central para efetuar a colaboração com os demais entes federados foi bastante reduzido, principalmente no que diz respeito à educação infantil e ao ensino fundamental. O Fundef se estabeleceu por um período de dez anos (1997 a 2007).

No primeiro governo de Lula da Silva (2003-06), o Fundef manteve-se inalterado, mas foi sendo elaborada, desde 2003, a proposta de um novo fundo, tendo como desfecho a sua aprovação por meio da EC n. ${ }^{\circ}$ 53/2006. Em 2007, primeiro por medida provisória e, depois, pela Lei n. ${ }^{\circ} 11.494 / 2007$, foi regulamentado o Fundo de Manutenção e Desenvolvimento da Educação Básica e de Valorização dos Profissionais da Educação (Fundeb), com previsão de vigência até o ano de 2020.

O Fundeb ampliou o quantitativo de estudantes para atender a toda a educação básica e, como consequência, também ampliou os recursos financeiros. Ampliou, comparativamente ao Fundef, a subvinculação de re- 
cursos de parte da receita resultante de impostos dos estados e municípios para a manutenção e desenvolvimento da educação a ser redistribuída, de modo que todos os entes federativos possam contribuir mais no esforço solidário de universalização do acesso dos alunos, com qualidade, em todas as etapas e modalidades da educação básica. Esse novo fundo abriu caminho para que fossem criadas as condições objetivas para a progressiva extensão da obrigatoriedade e gratuidade ao ensino médio e para a expansão da educação infantil e de jovens e adultos.

Com o Fundeb, houve uma significativa ampliação dos recursos da União, positivo para reduzir as disparidades regionais, porém ainda distante de cumprir sua função constitucional (art. 211) de garantir a equalização das oportunidades educacionais, assegurando um padrão mínimo de qualidade de ensino, pois os recursos ainda são insuficientes.

A União deve aplicar recursos na rede pública federal de ensino, além de ter a responsabilidade de transferir recursos para os sistemas estaduais e municipais. Na composição de suas receitas para a educação, os estados e municípios somam aos recursos próprios os recebidos da União; além disso, com o Fundeb, operam-se transferências de cada governo estadual aos seus municípios ou entre municípios de um mesmo estado. Ou seja, se seguido o estabelecido pela legislação, o financiamento deve se pautar pela colaboração entre os entes federados. Além disso, as ações supletiva e redistributiva da União e dos estados estão condicionadas à capacidade de atendimento e ao esforço fiscal de estados, do Distrito Federal e dos municípios.

De acordo com Araujo (2009), a legislação do Fundeb e a eliminação gradual da DRU para os recursos da MDE contribuíram para o aumento dos gastos federais destinados à educação. Apesar desse aumento no gasto público total em educação, o valor investido por aluno na educação básica no Brasil ainda é baixo quando comparado a países mais desenvolvidos ou até mesmo a países com nível de desenvolvimento semelhante.

\section{Considerações finais}

A compreensão da organização e das bases do financiamento da educação se coloca como uma necessidade para toda a sociedade, devendo envolver, especialmente, os gestores educacionais e toda a comunidade escolar e educacional. 
Porém, esse entendimento não é tarefa fácil. Discutir sobre o tema do financiamento da educação básica pública é tarefa urgente e necessária para gestores públicos, educadores, formuladores de políticas e pesquisadores do meio educacional. Isso porque pois quanto maior for o número de agentes esclarecidos e envolvidos com o tema, maior será o tensionamento junto aos diferentes níveis de governo para que os preceitos legais sejam cumpridos e os recursos ampliados.

Essa discussão constitui-se numa tarefa complexa, tendo em vista as condições materiais em que o financiamento se efetiva no país, envolvendo os diferentes entes federados - União, Estados, Distrito Federal e Municípios - e a esfera privada. A organização do sistema educacional brasileiro se caracteriza pela divisão de competências e responsabilidades entre os entes federados, o que se aplica também ao financiamento e à manutenção dos diferentes níveis, etapas e modalidades da educação e do ensino.

Colocar em prática todo esse jogo de relações entre os níveis de governo, envolvendo um complexo volume de arrecadações e redistribuições de bilhões de reais por ano, apresenta-se como um desafio a ser enfrentado pelos gestores públicos. Esses recursos são direcionados para a manutenção e o desenvolvimento do ensino, abrangendo recursos físicos e humanos, distribuição de alimentos e refeições, livros e materiais didáticos, serviços de transporte escolar, acesso aos meios digitais de aprendizagem e internet para alunos da rede pública da educação básica. Esses benefícios são ofertados diariamente a dezenas de milhões de crianças, jovens e adultos estudantes de escolas públicas, alcançados pelas ações e programas implementados em diferentes níveis e modalidades educacionais.

Estudos realizados por Castro (2009), Castro e Carvalho (2013), Pinto (2009) e Martins (2011) sobre o financiamento da educação pública no Brasil evidenciam que, nos últimos 15 anos, houve uma ampliação dos investimentos, porém esse volume de recursos não atende às necessidades de uma educação de qualidade. No estudo de Castro (2011), os dados revelam uma ampliação real do gasto em educação realizado pelas três esferas de governo entre 1995 e 2005, saindo de R \$ 61,4 bilhões para $\mathrm{R}$ \$ 87 bilhões, um crescimento real de 42\% em 11 anos, equivalente a 3,5\% ao ano. Em 2007, a prioridade de gastos para o ensino fundamental deveu-se, largamente, ao extinto Fundef, que introduziu, além da subvinculação de $60 \%$ dos gastos estaduais e municipais exclusivamente para aquele nível de ensino, uma forma inovadora de repartição dos recursos para o ensino fundamental, 
principalmente ao estipular uma equalização do valor do gasto por aluno/ ano com base em um indicador educacional - a matrícula (Castro, 2011).

Mesmo com a ampliação dos investimentos, nos últimos anos, a atual capacidade de financiamento é insuficiente para viabilizar alternativas mais ousadas de ampliação da oferta e melhoria dessa qualidade.

\section{Referências}

ARAÚJO, L. "O financiamento da educação básica no segundo mandato do governo Lula”. In Insumos para o debate: financiamento da Educação no governo Lula. São Paulo: Campanha Nacional pelo Direito à Educação, 2009, pp. 34-51.

BRASIL. Lei de Diretrizes e Bases da Educação Nacional no 9.394/96. São Paulo, 1998.

. Constituição da República Federativa do Brasil. Brasília, 1988. Disponível em: www.planalto.gov.br. Acesso em: 5 mai. 2014.

CASTRO, J. A. "Política social e desenvolvimento no Brasil". Economia e Sociedade, Campinas. v. 21. Número Especial, pp. 1011-1042, dez. 2011.

e CARVAlHO, C. H. A. de. "Necessidades e possibilidades para o financiamento da educação brasileira no Plano Nacional de Educação". Educação \& Sociedade, v. 34, n. 124, pp. 829-49, Campinas, 2013. Disponível em: http://www.scielo.br/pdf/es/v34n124/10.pdf. Acesso em: 5 nov. 2015.

e . de. "Necessidades e Possibilidades para o Financiamento da Educação Brasileira no Plano Nacional de Educação”. Educação \& Sociedade, v. 34, n. 124, pp. 829-849, 2013.

e DUARTE, Bruno de Carvalho. Descentralização da Educação Pública no Brasil: evolução dos gastos e matrículas. [S.l.], 2007.

e RIBEIRO, José Aparecido Carlos. As Políticas Sociais e a Constituição de 1988: conquistas e desafios. Políticas Públicas: acompanhamento e análise [Introdução. Número especial. Vinte Anos da Constituição Federal]. Brasília, IPEA, n. 17, pp. 17-97, 2009. 
et al. Simulando resultados para algumas alternativas de financiamento da educação básica. [S.1.]: Undime, 2005. Disponível em: www. undime.org.br. Acesso em: 17 set. 2016.

et al. Simulando Resultados para Algumas Alternativas de Financiamento da Educação Básica. [S.I.], Undime, 2005.

DAVIES, Nicholas. O Fundef e o Orçamento da Educação: desvendando a caixa preta. Niterói: Xamã, 1998.

. Financiamento da Educação: novos ou velhos desafios? São Paulo: Xamã, 2004.

. "A Política Recente de Fundos para o Financiamento da Educação e seus Efeitos no Pacto Federativo". Educação e Sociedade, Campinas, v. 28, n. 100, Especial, pp. 877-897, out. 2006.

. "Financiamento da educação: controle social e regulação do setor público e da iniciativa privada”. In XXIV Simpósio Nacional da ANPAE. Vitória: UFES, 2009.

FARENZENA, N. "Implementação de planos de ações articuladas municipais: marcos e trajetórias de uma pesquisa de avaliação”. In (org.). Implementação de planos de ações articuladas municipais: uma avaliação em quatro estados brasileiros. Pelotas: Editora UFPel, 2012, pp. 11-30.

. "As políticas de assistência financeira da União no marco das responsabilidades (inter)governamentais em educação básica”. In GOUVEIA, A. B. et al. (orgs.). Federalismo e políticas educacionais na efetivação do direito à educação no Brasil. Brasília: IPEA, 2011, pp. 95-110.

LUCE, M. B. e FARENZENA, N. "Custos educacionais - notas metodológicas de uma revisão da legislação e da literatura brasileiras”. In DOURADO, L. F. Financiamento da educação básica. Campinas: Autores Associados; Goiânia: Editora da UFG, 1999, pp. 61-84.

MARTINS, Paulo de Sena. FUNDEB, federalismo e regime de colaboração. Campinas: Autores Associados, 2011.

. O Financiamento da Educação Básica como Política Pública. RBPAE, Porto Alegre, v. 26, n. 3, pp. 497-514, set./dez. 2010. 
. O Financiamento da Educação Básica por Meio de Fundos Contábeis: estratégia politica para a equidade, a autonomia e o regime de colaboração entre os entes federados (tese). Universidade de Brasília, 2009.

MONLEVADE, J. A. C. de e FERREIRA, E. B. O Fundef e seus pecados capitais: análise do fundo, suas implicações positivas e negativas e estratégias de superação de seus limites. Brasília: Ideia Editora, 1998.

$\mathrm{e}$ O Fundef e seus pecados capitais. Brasília: Idéa, 1997.

OLIVEIRA, Maria Marly. Como fazer pesquisa qualitativa. 2. ed. Petrópolis: Vozes, 2008.

PINTO, J. M. de R. Os recursos para a educação no Brasil no contexto das finanças públicas. Brasília: Plano, 2000.

. "Um Fundinho chamado 'Fundo"'. In DOURADO, Luiz Fernandes. Financiamento da Educação Básica. Goiás: Ed. UFG - Autores Associados, 1999, pp. 85-98.

- "Financiamento da educação no Brasil: um balanço do governo FHC (1995-2002)”. Educação \& Sociedade, v. 23, n. 80, pp. 109-36, Campinas, set. 2002.

SILVA, M. S. P. Mudanças nos marcos regulatórias da educação brasileira no periodo de 2003 a 2010: uma análise das alterações na constituição federal e na LDB. Disponível em: http://www.anpae.org.br/iberoamericano2012/ trabalhos/_gt7. Acesso em: 5 mai. 2016. 


\title{
Algumas reflexões sobre educação especial
}

\author{
Gabriela Dambrós \\ Solange de Moura Trindade
}

\section{Introdução}

O presente capítulo tem o propósito principal de oferecer ao leitor uma ideia geral acerca da possibilidade e da necessidade legal de implementar uma educação especial inclusiva, superando, de uma vez por todas, o paradigma da educação especial excludente e segregadora, que propõe uma educação que integra, mas não inclui, em desconformidade com as orientações legais internacionais e nacionais.

A metodologia utilizada neste trabalho consistiu na pesquisa bibliográfica de obras especializadas, bem como na leitura e análise das políticas públicas legislativas e programas oriundos do Poder Público na esfera federal, especialmente os resultantes da assinatura e ratificação de tratados internacionais que versem sobre a matéria. É importante salientar ainda que utilizamos dados informados pelo Poder Público, na dimensão antes referida.

O presente trabalho se estrutura em quatro blocos, além da introdução, considerações finais e bibliografia. O primeiro, denominado "Apontamentos histórico-sociais acerca do tratamento conferido ao PNEE" apresenta ao leitor uma ideia geral acerca de como a sociedade em seus diferentes momentos históricos tem tratado o portador de necessidades especiais. Segue-se o item denominado "Escolarização de alunos(as) portadores(as) de necessidades educacionais especiais - APNEE", no qual se priorizará o portador de necessidades especiais enquanto partícipe de uma relação de ensino e aprendizagem em situação escolar. Nesse contexto, identificam-se as diferentes concepções de ensino disponibilizadas para esses indivíduos. Enfatizaremos conceitos de Educação Especial, Educação para a Integração 
e, por fim, o conceito mais apropriado para a escolarização dos portadores, que é a Educação Inclusiva, com seus pressupostos de que toda a sociedade e comunidade escolar devam se preparar, assim como o portador, para a partilha dos mesmos espaços escolares, sempre que as condições do portador permitam.

O terceiro bloco, denominado "Dispositivos internacionais de educação inclusiva” pretende dar ao leitor uma ideia geral acerca da matéria de Educação Especial, regulamentada pelos tratados internacionais dos quais o Brasil é signatário, ajustando sua legislação interna.

Por fim, no item "Elementos para uma educação inclusiva", apontamos algumas considerações identificadas na bibliografia como importantes para pôr em prática a inclusão educacional, sem nos esquecermos, no entanto, das dúvidas e resistências recorrentes a esse modelo de Escola.

\section{Apontamentos histórico-sociais acerca do tratamento conferido ao PNEE}

Este tópico pretende oferecer ao leitor uma ideia introdutória e panorâmica acerca dos diferentes tratamentos destinados à aluno(a) portador(a) de necessidades educacionais especiais (APNEE) no decorrer da história. Informamos ainda que a intenção é trazer à tona algu mas discussões e construções sócio-históricas responsáveis pela segregação no tratamento do APNEE.

A segregação histórica impingida ao deficiente vem construindo um cenário de exclusão que a educação inclusiva pretende abolir.

Fonseca (1995, p. 200), aponta que, no passado, a sociedade desenvolveu inúmeros obstáculos à integração da pessoa com deficiência. Esse tratamento depreciativo destinado a tal grupo social vem sendo, desde a Idade Média, marcado por medos, superstições e receios que faziam com que o deficiente fosse tratado como indesejado e inferior.

Sassaki (1997) informa ainda que a educação foi percebida em diferentes estágios: da segregação institucional, da integração e, atualmente, de um paradigma de inclusão.

A primeira fase identificada por Sassaki, ou seja, a segregação institucional, foi marcada por motivos filantrópicos e religiosos, não havendo uma preocupação mais significativa com a qualidade da atenção destinada a esses indivíduos. 
A fase de integração iniciou-se em meados do século XIX, com a criação de instituições especializadas, tanto médicas quanto educacionais, para o tratamento de deficientes. Foi nessa fase que surgiram as escolas especiais, como espaços muitas vezes dentro das escolas regulares, na forma de algumas classes e, ainda, com espaço exclusivo para os deficientes.

A constituição das classes especiais tinha como função garantir uma rigorosa seleção, que "identificasse apenas as crianças com potencial acadêmico, onde aquelas crianças, consideradas deficientes, não interferissem no ensino e na atuação do(a) professor(a) perante a maioria dos(as) alunos(as) da classe regular" (Sassaki, 1997, p. 113).

Sassaki enfatiza a necessidade de mudança desse paradigma com o propósito de que as pessoas com deficiências participem efetivamente e em igualdade de condições com o restante da sociedade. Para que isso ocorra, é preciso romper com o paradigma da integração, pressupondo que o indivíduo com deficiência se adapte à sociedade (integração), sendo necessário que a sociedade se adapte às pessoas com deficiência (inclusão).

Passamos, agora, a disponibilizar ao leitor informações de cunho histórico e social acerca do tratamento conferido aos deficientes ao longo do tempo.

Durante a Antiguidade Clássica, predominavam padróes estéticos rigorosos nas cidades gregas e nas cidades romanas. O excessivo culto a beleza apolínea fazia com que pessoas portadoras de deficiência física e mental fossem consideradas subumanas, sendo indesejáveis naquela sociedade e, em alguns momentos, abandonadas ou mortas pelos seus próprios familiares logo após o nascimento.

Com a Idade Média e a consolidação do cristianismo, modifica-se, consideravelmente, o tratamento destinado aos deficientes. Inicia-se uma fase de acolhimento, fazendo-se com que muitas crianças com deficiência escapassem da morte. Nas palavras de Pessotti, "o deficiente ganha alma e, como tal não pode ser eliminado ou abandonado sem atentar-se contra desígnios da divindade, tornam-se pessoas e filhos de Deus" (Pessotti, 1984, p. 5).

A ética cristã que orienta o período, apesar de tratar o deficiente como filho de Deus, percebe a deficiência preconceituosamente, na medida em que a considera como castigo de Deus em razão de pecados de seus ascendentes ou do(a) próprio(a) portador(a). O cristianismo passa a conceber a deficiência pelo paradigma castigo/caridade, isolando o portador de deficiência, "escondendo em asilos e orfanatos". Informa ainda que, nesse período, a Inquisição - Tribunal Eclesiástico da Igreja Católica - sacrificou inúmeros(as) portado- 
res(as) de deficiência mental, por considerá-los pecadores ao não se comportarem da forma indicada para um(a) bom(oa) cristão(ã). ${ }^{1}$

Esse tratamento desumano e segregador encontrou guarida ainda por muitos séculos. Quando da Reforma Protestante, em meados do século XVI e durante o século XVII, período referido por Pessotti como “época dos açoites e das algemas" na trajetória histórica da deficiência, a situação se manteve. $\mathrm{Na}$ obra do autor supraindicado, encontra-se a seguinte passagem atribuída a Lutero:

Ao oito anos vivia em Dessau um ser que eu, Martinho Lutero, vi e contra o qual lutei. Ao doze anos possuía visão e todos os outros sentidos, de forma que só se podia tomar por uma pessoa normal; mas, ele não fazia outra coisa senão comer, tanto como quatro camponeses na ceifa. Comia, defecava, babava-se, e quando lhe tocavam, gritava. Quando as coisas não corriam como queria, chorava. Então eu disse ao príncipe de Anhalt: se eu fosse o príncipe, levaria esta criança ao Moldau que corre perto de Desseu e a afogaria. Mas o príncipe de Anhalt e o príncipe de Saxe, que se achava presente, recusaram seguir meu conselho. Então eu lhe disse: pois bem, os cristãos farão orações divinas na igreja, a fim de que Nosso Senhor expulse o demônio. Isso se fez diariamente em Dessau e o ser sobrenatural morreu nesse mesmo ano (Pessotti, 1984, p. 12).

É importante informar que o tratamento dado tanto por católicos quanto por protestantes ao deficiente resulta de estudos de meados do século XVI, quando começaram a tratar a deficiência mental sob o prisma médico. Merece destaque a obra Sobre as doenças que privam os homens da razão (1526), de Paracelso (1493-1541), na qual é dito que o "louco e o idiota" não são mais perversas criaturas tomadas pelo demônio, mas doentes ou vítimas de forças sobre-humanas e dignos de tratamento e complacência (Pessoti, 1984, p. 15).

No ano de 1534, a deficiência e a loucura passam, também, a ser matérias de direito. A lei define o idiota e o louco como indivíduos incapazes de contar

\footnotetext{
${ }^{1}$ A maior causa de perseguição a deficientes mentais pelo Tribunal da Inquisição decorria, especificamente, do denominado "descontrole sexual" desse grupo social, avaliado pela Igreja como atentatório, de acordo com o que consta nos livros de história medieval.
} 
até 21 , bem como dizer quem eram seus pais. O critério jurídico é a ausência ou perda da razão.

John Locke (1632-1704) afirmava que, assim como o recém-nascido, a mente do deficiente era uma folha em branco, sendo pertinente desenvolver nele a experiência sensorial como elemento preliminar para o domínio de processos mentais mais complexos.

Pessotti cita, ainda, Jean Marc Gaspard Itard (1774-1838) que, como médico-chefe do Imperial Instituto de Surdos-Mudos, desenvolveu importantes trabalhos sobre a gagueira, oralidade e audição, sendo considerado o fundador da otorrinolaringologia. Itard, com sua crença na educabilidade do deficiente, desenvolveu um importante programa de educação especial para surdos-mudos no ano de 1800, no qual propôs a utilização de leitura labial, enfatizando, ainda, a estreita ligação entre fonação e audição, o que, para a época, era uma inovação.

Um importante caso estudado por Itard ficou conhecido como o caso do "selvagem de Aveyron", chamado Victor. Esse menino foi capturado em 1797, conseguindo fugir e esconder-se na mata por, aproximadamente, 15 meses. No ano de 1800, ele foi encontrado e internado no Asilo Saint-Affrique, onde são registrados dados como estatura, peso, sons emitidos, cóleras súbitas, gosto pelas chamas e a incapacidade de entender sua imagem refletida no espelho. Victor foi, então, examinado por Itard e por outro importante psiquiatra francês, o dr. Philippe Pinel (1745-1826). O diagnóstico de Pinel identificou Victor como portador de um retardo mental profundo e fez com que Itard acreditasse que as causas estariam condicionadas ao isolamento do menino. Assim, enfatiza a importância do fenômeno de socialização, que não seria inata, havendo a necessidade de estimulação.

Embora Itard seja considerado um médico-pedagogo, acreditava que a deficiência fosse pertinente apenas ao campo da medicina, visto tratar-se de uma patologia, sendo um problema eminentemente orgânico e medicável.

A partir das reflexões de Itard, inicia-se uma preocupação de cunho pedagógico com o deficiente, que somente se consolida com os estudos de Édouard Séguin (1812-1880). Este, além de médico, foi um estudioso da didática e fez em seus estudos referências à possibilidade de aplicação de seu método na "educação de crianças idiotas no ensino regular" (Bautista, 1997, p. 24).

Nas primeiras décadas do século XX, os estudos mais sistematizados acerca da deficiência começam a ganhar terreno e aproximam as discussões 
referentes à psicologia, à biologia, à genética e à educação. Tais estudos indicam uma paulatina possibilidade de incorporação do deficiente na sociedade.

Ainda sobre o texto extremamente preconceituoso conferido aos deficientes, tanto físicos quanto mentais, pode-se referir ao período do nazismo alemão como sendo uma experiência profundamente negativa no tratamento desses grupos sociais. Isso porque, na busca do ser humano perfeito, ideário do nazismo, qualquer um que apresentasse diferenças em relação ao padrão indicado como ideal era considerado inoportuno para a sociedade alemã. Em razão disso, presenciam-se a segregação e o extermínio de um número significativo de deficientes.

A partir de meados da década de 1960, inicia-se um movimento para modificar a concepção de deficiência, cuja preocupação era a integração social dos deficientes, enfatizando-se o entendimento das questôes educacionais para contribuir na efetiva inclusão idealizada atualmente.

O conceito de "necessidades educacionais especiais" foi utilizado, pela primeira vez, no Relatório Warnock, publicado em 1978, que propôs a educação de alunos(as) com necessidades especiais em espaços menos restritivos. Com essa abordagem, não se coloca de lado a complexidade da criança portadora de necessidades especiais, mas é enfatizado, o papel da escola, que deverá se estruturar para acolher, abrigar, resguardar as necessidades de todos(as) seus(suas) alunos(as).

Nessa perspectiva, as necessidades educacionais especiais são definidas e identificadas na relação concreta entre o(a) aluno(a) e a educação escolar, de tal sorte que os recursos educacionais especiais exigidos em tal situação se configurem como educação especial, não sendo reduzidos a uma classe ou atendimento especial.

A atual política nacional de educação especial entende o(a) aluno(a) com necessidades educacionais especiais como "pessoa que apresenta, em caráter permanente ou temporário, algum tipo de deficiência física, sensorial, cognitiva, múltipla, condutas típicas ou altas habilidades, necessitando, por isso, de recursos especializados para desenvolver mais plenamente o seu potencial e/ ou superar ou minimizar suas dificuldades" (Brasil, 2001).

Quanto à recente utilização da denominação "necessidades educacionais especiais”, esse termo tem sido alvo de inúmeras críticas. Alguns o consideram vago e pouco elucidativo, enquanto outros entendem que a simples substituição do termo "deficiente" por "portador(a) de necessidades especiais" não faz com que as dúvidas/preconceitos desapareçam. 
Amaral (1996, p. 4) afirma que “ cada um de nós que vive a condição de diferença/deficiência precisa e quer ser reconhecida nela, mas não identificado com ela".

Nesse mesmo texto, a autora enfatiza que os termos "débil", "idiota" e "mongoloide" passaram a ser concebidos como insulto, bem como as denominações "excepcional" e "deficiente", hegemônicas, nas décadas de 1970 e 1980 , por trazerem uma carga estigmatizante. Tal autora sugere a utilização do conceito "pessoa com deficiência" por entender que

Esta forma verbal acentua o aspecto dinâmico da situação; desloca o eixo de atributo do indivíduo para sua condição e, simultaneamente, recupera a pessoa como 'sujeito da frase', colocando a deficiência não como sinônimo da pessoa (como ocorre ao tornar substantivo aquilo que é qualitativo) e seu decorrente risco de etiquetagem; tem um caráter mais descritivo que valora e, finalmente, sublinha a unicidade do indivíduo (pp. 4-5).

Atualmente, os indivíduos são concebidos como resultantes de fatores biológicos e de fatores histórico-sociais. Ainda que a fase clínico/assistencialista não possa ser considerada como passado, o presente vê crescer a ideia de inclusão e de identificação dos deficientes como sujeitos de direito.

Pela leitura da bibliografia utilizada, percebemos diferentes denominações: até o século XIX - idiota, imbecil, cretino e demente; em meados do século XX - deficiente; no final da década de 1980 - excepcionais e especiais; e, nos dias atuais - alunos(as) com necessidades educacionais especiais. É importante salientar que muitas pessoas, instituições e inclusive legislações utilizam ainda hoje o termo excepcional e deficiente.

No atual contexto, acredita-se na importância do processo de incorporação das pessoas com deficiência, percebendo-as como absolutamente capazes de aprender e com o direito de acessar os conhecimentos historicamente acumulados pela sociedade ao longo de sua trajetória, em que o(a) professor(a) poderá garantir as interações sociais entre os diferentes. 


\section{Escolarização de alunos(as) portadores(as) de necessidades educacionais especiais - APNEE}

A utilização da denominação "educação especial" tem ocorrido para identificar um atendimento escolar distinto e separado de educação geral, ou seja, das denominadas classes "normais" ou regulares. As classes especiais, como espaços distintos de aprendizagem, são destinadas às pessoas com alguma deficiência física, sensorial ou cognitiva.

Devido ao discurso de que "estas pessoas possuem especificidades, necessitando, dessa forma, de uma educação diferenciada”, elas foram excluídas do sistema do ensino ofertado pela escola regular. Cumpre informar que a distinção pode ocorrer considerando-se três contextos distintos:

a. $\mathrm{O}(\mathrm{A})$ aluno(a) portador(a) de necessidades especiais;

b. A formação especializada dos(as) professores(as) destinados a lidar com este(a) aluno(a); e

c. O lugar, o espaço onde ocorre essa educação, ou seja, uma instituição especializada para o tratamento dos(as) alunos(as) portadores(as) de necessidades especiais.

Hoje, estudiosos da temática sentem a necessidade de rever essa concepção de educação especial, que separa e isola o(a) portador(a) de necessidades especiais. Assim, passaríamos de uma educação especial segregadora para uma educação especial inclusiva, com uma proposta de educação para todos, na qual a comunidade escolar - pais, alunos(as), professores(as) e funcionários(as) - discutisse ou pensasse a inclusão educacional da criança portadora de necessidades especiais. Sem dúvida, um processo bastante complexo e desafiador.

Nas palavras de Mônica Kassar: "O especial e o comum são vistos como dois problemas distintos que vêm disputando o mesmo espaço, o mesmo lugar físico: a escola pública” (Kassar, 1995, p. 27).

Historicamente, o sentido de "normal" e "diferente", no que tange às questôes educativas, vem sendo respaldado em classificaçóes desde tempos remotos e com base, geralmente, nas características do processo ensino/aprendizagem, pressupondo, equivocadamente, que todas as pessoas ao aprenderem adotam um único padrão, que, em razão de sua pretensa uniformidade, acaba 
por esvaziar as possibilidades de pessoas que não se encaixam perfeitamente nesse padrão.

Dessa forma, qualquer aluno(a) que apresente dificuldades na aprendizagem, quando exposto aos métodos convencionais de ensino, poderá ser rotulado como deficiente e incapaz.

A educação especial na forma predominante, segregadora, contribuiria para o ajustamento, para a reabilitação desse(a) aluno(a), negligenciando, descuidando, desatendendo à participação do(a) portador(a) de necessidades especiais no processo de aprendizagem, em que pese o esforço de algumas instituições que enfatizam esse procedimento.

A implantação de uma educação comum e inclusiva faz com que todos os envolvidos revisem seus referencias teóricos, ainda profundamente marcados por uma ideia de quantificação e de mensuração da aprendizagem, buscando, antes de qualquer coisa, a regularidade. É importante referir Mazzota (1993, p. 27), que afirma:

Algumas modificações são, às vezes, requeridas na organização e no funcionamento da educação escolar para que tais alunos usufruam os recursos escolares de que necessitam para o alcance daqueles objetivos. Em razão disso, são organizados auxílios e serviços educacionais especiais para apoiar, suplementar e, em alguns casos, substituir o ensino regular, como forma de assegurar o ensino para este alunado. Tais auxílios e serviços educacionais são planejados e desenvolvidos para assegurar respostas competentes por parte do sistema e da unidade escolar, ainda que às necessidades especiais ou diferenciadas apresentadas por determinados alunos no contexto escolar em que se encontram. As necessidades educacionais especiais são definidas e identificadas na relação concreta entre o educando e a educação escolar. Assim, os recursos educacionais especiais requeridos na situação de ensino-aprendizagem é que se configuram como 'educação especial' e não devem ser reduzidos a uma outra modalidade administrativa-pedagógica como escola especial.

A divisão entre ensino especial e ensino regular tem marcado o tratamento conferido pela sociedade e pelo poder público. Nas palavras de Ferreira (1998, p. 25), "é importante que não se exclua sob a bandeira da inclusão". 
Cumpre referir, ainda, que um dos maiores obstáculos à educação inclusiva se encontra nos(as) professores(as), que, via de regra, não estão preparados e habilitados para educar alunos(as) portadores(as) de necessidades especiais. Alguns autores atribuem essa resistência à hegemonia da concepção dicotômica especial-regular, que, historicamente, enfatiza que pessoas diferentes devem ser tratadas em lugares diferentes por pessoas com formação diferenciada; somente assim as "deficiências" do(a) portador(a) de necessidades especiais seriam sanadas/amenizadas.

\section{Dispositivos internacionais de educação inclusiva}

A temática da Educação Especial, debatida mundialmente, está contemplada em inúmeros documentos internacionais, como tratados e acordos, e, para melhor encaminhar a questão, ${ }^{2}$ os países que assinam e ratificam esses dispositivos implementam ações, criando foros de discussão permanente.

Essa reflexão priorizará três desses momentos: um estudo solicitado pela Unesco, em meados da década de 1960, cujo resultado mais evidente foi a sistematização, recebendo o nome de Cascata de Deno; a Convenção Educação para Todos, realizada em 1990; e a Declaração de Salamanca, de 1994.

O primeiro estudo resultou de um trabalho de especialistas convocados pela Unesco, com o propósito de pensar um programa para esse grupo social. Essa comissão de especialistas trabalhou durante boa parte da década de 1960, tendo resultado em um tratado assinado por países europeus e pelos Estados Unidos.

A inclusão desses(as) alunos(as) na rede escolar regular ganha forma com a proposta elaborada por um estudioso da temática Cascata de Deno, que propunha a retirada de crianças dos espaços restritivos, com a adaptação do(a) aluno(a) à escola.

A Cascata de serviços de Deno, como ficou conhecida a proposta, estabelecia que:

\footnotetext{
${ }^{2}$ Entre as inúmeras orientações acerca do tratamento destinado ao portador de necessidades especiais, indicaremos alguns pela sua importância, bem como pela sua referência frequente na bibliografia especializada. Declaração de Cuenca, 1981.
} 


\section{Nível I}

$\mathrm{O}(\mathrm{a})$ aluno(a) permanece na classe regular. Professor do ensino regular recebe orientações do professor de Educação Especial (consultor) e de quaisquer outros especialistas tidos como necessários. O professor do ensino regular dirige o Programa de Intervenção.

\section{Nível II}

$\mathrm{O}(\mathrm{a})$ aluno(a) permanece na classe regular, recebendo apoio direto do professor de Educação Especial (itinerante). Programa dirigido pelo professor de Ensino Regular com a colaboração do professor de Educação Especial.

\section{Nível III}

O aluno(a) frequenta classe regular e sala de apoio. Programa de intervenção, dirigido pelo professor do Ensino Regular e pelo professor de Educação Especial.

\section{Nível IV}

$\mathrm{O}(\mathrm{a})$ aluno(a) frequenta a sala de apoio. Programa de intervenção dirigido pelo professor de Educação Especial.

\section{Nível V}

Aluno(a) frequenta Escola Especial. Programa elaborado por especialistas, entre os quais figura o professor de Educação Especial.

\section{Nível VI}

Aluno(a) recebe serviços de Educação Especial no seu domicílio. Programa elaborado por especialistas, entre os quais figura o professor de Educação Especial.

\section{Nível VII}

Aluno(a) recebe serviços de educação especial em instituições especializadas: hospitais, lares, etc. Programa elaborado por especialistas.

A partir da identificação do educando com necessidades especiais, este era indicado, então, para tratamento em um dos níveis, podendo progredir ou regredir. 
Na década de 1980, surge um outro conceito sobre Educação Especial fundado na ideia de inclusão, tomando como ponto de partida não o(a) aluno(a), mas a escola. No período anterior, o(a) aluno(a) que deveria se adaptar à escola; agora, a escola que deve se adaptar ao aluno(a). Esse conceito vigora hoje nas orientações emanadas pelo poder público no que se refere à matéria.

$\mathrm{Na}$ Europa, a Itália e a Espanha destacaram-se quanto às políticas contra a exclusão do(a) portador(a) de necessidades especiais.

O Tratado Mundial de Educação para Todos, resultante de um encontro ocorrido em 1990 na Tailândia, mostrou as questões educativas com um caráter prioritário. Nesse documento, 155 países se comprometem a garantir uma educação básica de qualidade para todas as crianças, jovens e adultos.

Torres (2001, pp. 26-7) aponta algumas estratégias presentes na Convenção Educação para Todos:

1. Satisfazer as necessidades básicas de aprendizagem de todos, reconhecendo que cada um tem necessidades diferentes e, por isso, exige conteúdos, métodos e modalidades próprias;

2. Priorizar meninas e mulheres abolindo obstáculos que as impedem de ter acesso à educação, exterminando qualquer tipo de discriminação sexista no espaço escolar;

3. Dar especial atenção aos grupos desamparados e às pessoas com algum tipo de deficiência, facilitando a sua aprendizagem e corrigindo as desigualdades educativas impostas a elas; (grifo nosso)

4. Concentrar a atenção mais na aprendizagem do que nos aspectos formais, garantindo que as pessoas realmente aprendam além de criar mecanismos que garantam o acesso e a permanência de todos na escola;

5. Priorizar o ambiente de aprendizagem, enfatizando as condições como matérias mínimas.

Pela leitura dos principais apontamentos da Convenção Educação para Todos, verifica-se uma acentuada orientação no sentido efetivo de contemplar todos. A mesma autora enfatiza ainda que "o diferente passa a ser a norma e não a exceção nos sistemas destinados a satisfazer tais necessidades" (2001, p. 81).

No ano de 1994, como resultado imediato da Conferência da Tailândia, foi organizado, pelo governo espanhol, em parceria com a Unesco, um encon- 
tro que deu origem à Declaração de Salamanca, com a finalidade de definir políticas, princípios e práticas para discutir a educação destinada aos portadores de necessidades especiais. É importante salientar que foram consideradas, nessa declaração, crianças e jovens cujas necessidades decorrem de suas capacidades e dificuldades de aprendizagem, em algum momento de sua escolarização.

Para garantir a inclusão desses(as) alunos(as) na rede regular de ensino, faz-se referência ao princípio da escola para todos, no que tange ao reconhecimento das diferenças e promoção da aprendizagem.

Todos os países signatários da Convenção de Salamanca aceitaram o desafio, de modo a viabilizar a Educação para Todos, colocando em prática ações inclusivas.

Reafirmando:

O direito de todas as pessoas à educação, conforme Declaração Universal dos Direitos Humanos de 1948, e renovando o empenho na Conferência Mundial sobre Educação para todos de 1990, de garantir esse direito independentemente de suas diferenças particulares;

Recordando:

As diversas declarações das Nações Unidas, que culminaram nas "Normas uniformes sobre Igualdade e Oportunidade para as pessoas com Deficiência” nas quais os Estados são instados a garantir que a educação de pessoas com deficiência seja parte integrante do sistema educativo;

Observando:

[...] a maior participação dos governos, de grupos de apoio, de grupos comunitários, de pais e, especialmente de organizações de pessoas com deficiências nos esforços para melhorar o acesso ao ensino, da maioria das pessoas com necessidades especiais ainda marginalizadas (Salamanca, 1994, p. 9).

No corpo documental da Declaração, encontramos a expressão "necessidades educativas especiais", além do conceito de "escolas inclusivas". No artigo quarto do mesmo documento, evidencia-se um apelo ao respeito da diferença, além da necessária mudança na perspectiva social em relação às pessoas com deficiência, vítimas reiteradas de discriminação generalizada. 


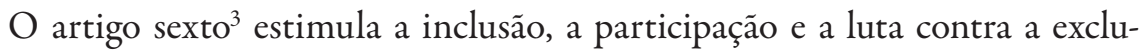
são, sugerindo a integração nas escolas como um esforço do poder público, dos(as) professores(as), dos pais, dos funcionários da escola, dos voluntários e dos próprios educandos. No artigo sétimo, ${ }^{4}$ é apontado o princípio fundamental das escolas únicas, em que todas as crianças, sempre que possível, devam aprender juntas, independentemente de suas dificuldades de aprendizagem. A escola deverá se adaptar aos diferentes estilos e ritmos de aprendizagem, com qualidade de ensino, organização escolar, rigorosa utilização dos recursos humanos, estrutura física e entrosamento com suas comunidades.

\section{Elementos para implantar uma educação inclusiva}

A temática da inclusão escolar do PNEE coloca-se, na atualidade, como um dos maiores desafios a ser enfrentado pela sociedade brasileira, que assumiu expressamente esse compromisso quando assinou e ratificou tratados internacionais que dispõem sobre a temática. Inegavelmente, Escolas Inclusivas qualificariam a Educação Básica e a Educação Superior, o que garantiria uma inserção mais qualificada dos portadores de necessidades especiais no

\footnotetext{
3 "Art. $6^{\circ}$. A tendência em política social durante as duas últimas décadas tem sido a de promover integração e a participação e de combater a exclusão. Inclusão e participação são essenciais à dignidade humana e ao desfrutamento e exercício dos direitos humanos. Dentro do campo da educação, isto se reflete no desenvolvimento de estratégias que procuram promover a genuína equalização de oportunidades. Experiências em vários países demonstram que a integração de crianças e jovens com necessidades educacionais especiais é melhor alcançada dentro de escolas inclusivas, que servem a todas as crianças dentro da comunidade. É dentro deste contexto que aqueles com necessidades educacionais especiais podem atingir o máximo progresso educacional e integração social. Ao mesmo tempo em que as escolas inclusivas prevêem um ambiente favorável à aquisição de igualdade de oportunidades e participação total, o sucesso delas requer um esforço claro, não somente por parte dos professores e dos profissionais na escola, mas também por parte dos colegas, pais, famílias e voluntários. A reforma das instituições sociais não constitui somente uma tarefa técnica, ela depende, acima de tudo, de convicções, compromisso e disposição dos indivíduos que compõem a sociedade."

4 “Art. $7^{\circ}$. Princípio fundamental da escola inclusiva é o de que todas as crianças devam aprender juntas, sempre que possível, independentemente de quaisquer dificuldades ou diferenças que elas possam ter escolas inclusivas devem reconhecer e responder às necessidades diversas de seus alunos, acomodando ambos os estilos e ritmos de aprendizagem e assegurando uma educação de qualidade à todos através de um currículo apropriado, arranjos organizacionais, estratégias de ensino, uso de recurso e parceria com as comunidades. Na verdade, deveria existir uma continuidade de serviços e apoio proporcional ao contínuo de necessidades especiais encontradas dentro da escola."
} 
mercado de trabalho, que também busca implementar ações afirmativas que garantam o acesso aos postos de trabalho reservados a esse segmento social.

A título de ilustração, indicaremos algumas situações apontadas por Mantoan, que obstaculizam a implementação de uma escola efetivamente inclusiva e que devem ser reavaliadas para a passagem de uma Educação Especial Excludente para uma Educação Especial Inclusiva. São elas: a estrutura organizacional das escolas; o ensino tradicional e sua limitação; as reações dos(as) professores(as); e as atividades e recursos didático-pedagógicos (2003, pp. 29-36).

\section{Considerações finais}

O presente trabalho resulta da tentativa dos autores de compreender a questão educacional da pessoa com deficiência, especialmente no que diz respeito à sua formação escolar, que possibilitará uma inserção mais qualificada no mercado de trabalho.

A predisposição para esta pesquisa resulta da nossa preocupação com a reduzida procura pelas vagas disponibilizadas no mercado de trabalho para a pessoa com deficiência, apesar de haver uma legislação bastante rigorosa e aplicada, especialmente no que se refere ao concurso para ingresso no serviço público. Um argumento recorrente para o não preenchimento das vagas abertas é a reduzida escolaridade das pessoas com deficiência.

Em razão desta aparente contradição entre reserva de vagas no mercado de trabalho e a reduzida escolaridade das pessoas com deficiência, os autores propuseram-se a estudar, de uma maneira mais sistematizada, a formação escolar desse grupo.

O tratamento da pessoa com deficiência até bem poucas décadas era orientado por um referencial educacional, tendo se consolidado apenas em razão de estudos de psicologia da educação, sobretudo de teorias da aprendizagem, associados a uma significativa mudança cultural, na qual esses indivíduos não deveriam mais ficar segregados em asilos, hospitais ou em suas próprias casas, frequentando espaços delimitados separados, as chamadas Escolas Especiais.

As Escolas Especiais daquele período podem ser identificadas como tentativas de preparar/adaptar a pessoa com deficiência à sociedade, com a finalidade de integrá-las tão logo isso seja possível ou, melhor dizendo, quando o PNEE já estiver ajustado aos "espaços de normalidade". 
A partir de década de 1960, inicia-se um processo de transformação no atendimento dessas pessoas, colocando-as nas ditas escolas normais, mantendo-se, ainda, um vínculo com a Educação Especial e sustentando-se o pressuposto de que o aluno deve se adaptar à escola.

Em meados da década de 1980, surgiu um outro conceito sobre Educação Especial denominado de "inclusão", que tem como meta não deixar nenhum aluno fora da escola regular desde o início de sua escolarização, propondo que a adaptação deva ser feita pela escola e, consequentemente, por toda a sociedade.

No segundo tópico, tratamos especificamente sobre a escolarização de APNEE, fazendo referência às principais políticas públicas. No terceiro, fizemos alguns apontamentos acerca das possibilidades e dificuldades da implantação de uma escola inclusiva, uma vez que a temática tem gerado discussões calorosas, especialmente sobreostermos: "EducaçãoEspecial”, "aluno com necessidades educacionais especiais", "pessoas com deficiência”, "pessoas deficientes", "integração", "inclusão", entre outros.

É importante enfatizarmos a amplitude do conceito de inclusão e a necessidade de pensarmos a trajetória da Educação Especial, bem como a ênfase na escola como um espaço de aprendizagem para todos, quaisquer que sejam as restrições e comprometimentos que os alunos venham a apresentar no decorrer de sua trajetória escolar.

Os APNEE já têm esse atendimento escolar assegurado em lei, conforme demonstram nossos estudos, sendo necessário discutir a inclusão de fato, o que implica uma mudança significativa do comportamento da sociedade como um todo.

A perspectiva da inclusão coloca-se como um desafio para a sociedade brasileira no processo educacional em todos os níveis de ensino, desde a educação infantil até a educação superior, além de acessar serviços de apoio especializados.

Por fim, não podemos deixar de pensar na inclusão como possibilidade e desafio de rever profundamente o contexto sociocultural em que estamos inseridos, o que implicará inúmeras mudanças que viabilizarão a construção de um modelo de conhecimento que respeite as diferenças e estimule as potencialidades de todos os indivíduos. 


\section{Referências}

AMARAL, Lígia. "A deficiência: questões conceituais e alguns de seus desdobramentos”. Cadernos de Psicologia, n. 1, pp. 3-12, Ribeirão Preto, 1996.

BAUTISTA, Rafael. Necessidades educativas especiais. Lisboa: Dinalivro, 1997.

BRASIL. Ministério da Educação. Diretrizes nacionais para a educação especial na educação básica. Brasília: MEC, 2001.

. Política nacional de educação especial na perspectiva da educação inclusiva. Brasília: MEC, 2008.

CARVALHO, Rosita Edler. A nova $L D B$ e a educação especial. Rio de Janeiro: WVA, 1997.

. Temas em educação especial. Rio de Janeiro: WVA, 1998.

- Removendo Barreiras para a aprendizagem: educação inclusiva. Porto Alegre: Mediação, 2000.

DECLARAÇÃO DE SALAMANCA: Sobre princípios, políticas e práticas na área das necessidades educativas especiais. Salamanca - Espanha, 1994.

FERREIRA, Berta Weil. "Adolescência e inadaptação social". In STOBÄUS, Claus Dieter e MOSQUERA, Juan José Mouriño (orgs.). Educação Especial: em direção à educação inclusiva. Porto Alegre: EDIPUCRS, 2003, pp. 83-92.

FERREIRA, Júlio R. "A nova LDB e as necessidades educativas especiais". Cadernos CEDES, n. 46, Campinas, 1998.

FONSECA, Vitor da. Educação Especial: programa de estimulação precoce - uma introdução às ideias de Feuerstein. Porto Alegre: Artes Médicas, 1995.

. "Tendências futuras da Educação Inclusiva”. In STOBÄUS, Claus Dieter e MOSQUERA, Juan José Mouriño (orgs.). Educação Especial: em direção à educação inclusiva. Porto Alegre: EDIPUCRS, 2003, pp. 41-64. 
KASSAR, M. Ciência e senso comum no cotidiano das classes especiais. Campinas: Papirus, 1995.

MANTOAN, Maria Teresa Eglér. "Uma escola para todos e com todos: o mote da inclusão”. In MOSQUERA, Joan José Mourinõ (org.). Educação Especial: em direção à educação inclusiva. Porto Alegre: EDIPUCRS, 2003, pp. 27-40.

MAZZOTTA, Marcos J. S. Fundamentos de Educação Especial. São Paulo: Pioneira, 1982 . Educação Escolar: comum ou especial? São Paulo: Pioneira, 1987. . Trabalho docente e formação de professores de educação especial. São Paulo: EPU, 1993.

PESSOTTI, Isaías. Deficiência mental: da superstição à ciência. São Paulo: Editora da USP, 1984.

SASSAKI, Romeu Kazumi. Inclusão: construindo uma sociedade para todos. Rio de Janeiro: WVA, 1997.

TORRES, Rosa María. Educação para todos: a tarefa por fazer. Porto Alegre: Artmed, 2001. 


\section{Educação como ferramenta de preservação do patrimônio cultural brasileiro}

Luciana de Aguilar Belizio Idiane Manica Radaelli

O Instituto do Patrimônio Histórico e Artístico Nacional (IPHAN) é um dos institutos vinculados ao Ministério da Cultura (MinC) e, dessa forma, tem como finalidade articular e executar a preservação do patrimônio cultural no país. A execução dessa tarefa estabeleceu ações para o desenvolvimento social vinculadas às potencialidades do patrimônio cultural de cada cidade. Consequentemente, pode-se considerar que é uma ação democrática entre as três esferas do governo junto com a sociedade, e que assegura o desenvolvimento de uma política para a cultura, pois, quando um grupo social valoriza e conhece sua cultura, ocorre um desenvolvimento social, podendo promover uma sensibilização com respeito para a preservação do patrimônio cultural.

O IPHAN, desde sua criação, manifesta a importância de realizar ações educativas como estratégia de proteção e preservação do patrimônio cultural e também introduzir discussões teóricas, metodológicas e conceituais com base nas políticas públicas de Estado e da área. Essas ações de preservação propõem a mobilização da participação da sociedade civil em conjunto com o poder público governamental, com o objetivo de promover o desenvolvimento humano, social e cultural.

O IPHAN (2014) conceitua o patrimônio cultural como sendo os saberes, fazeres, expressões, práticas e seus produtos, que remetem à história, à memória e à identidade do povo. Portanto, faz-se importante, pois é constituído pela sociedade e simboliza as riquezas desta. Esses símbolos constituem a identidade, a partir da história, cultura, valores, objetos, práticas culturais, lugares, edificações e memórias, por desenharem os bens de uma sociedade e designarem uma reflexão de preservação desse patrimônio. 
A estima da participação da sociedade na preservação do patrimônio cultural está exposta na Constituição Federal de 1988, em seu artigo 216, que especifica que "constituem patrimônio cultural brasileiro os bens de natureza material e imaterial, tomados individualmente ou em conjunto, portadores de referência à identidade, à ação, à memória dos diferentes grupos formadores da sociedade brasileira”. Com base nisso, o patrimônio cultural define-se pelas formas de expressão; dos modos de criar, fazer e viver; das criações científicas, artísticas e tecnológicas; das obras, objetos, documentos, edificações e demais espaços destinados às manifestações artístico-culturais; e os conjuntos urbanos e sítios de valor histórico, paisagístico, artístico, arqueológico, paleontológico, ecológico e científico.

No entanto, a preocupação de preservar o patrimônio cultural brasileiro se deu a partir da década de 1930, quando o país, no regime do Estado Novo, teve o intuito de promover a unificação do povo. Dessa forma, foi criado o Serviço do Patrimônio Histórico e Artístico Nacional - SPHAN (1937). A partir disso, nascia uma integração dos estados brasileiros para constituir uma identidade nacional, que teve forma com intelectuais modernistas na busca das raízes brasileiras (Fausto, 2002). Posteriormente, em 1967, o SPHAN teve sua denominação alterada para Instituto do Patrimônio Histórico e Artístico Nacional (IPHAN), como é conhecido atualmente.

Já no anteprojeto para a criação do então Serviço do Patrimônio Histórico e Artístico Nacional - SPHAN, Mário de Andrade apontava para a relevância do caráter pedagógico estratégico dos museus e das imagens. A criação de um órgão federal dedicado à preservação do patrimônio histórico e artístico nacional foi motivada, de um lado, por uma série de iniciativas institucionais regionais e, de outro, por clamores e alertas de intelectuais, parte deles ligada à Semana de Arte Moderna de 1922, veiculados na grande imprensa brasileira (IPHAN, 2014).

Os intelectuais redescobriram o Brasil, uma definição da identidade brasileira (Amaral, 1997). Assim, nasceu um sentimento de identidade nacional, bem como políticas de constituição do patrimônio histórico e cultural do país (Canani, 2005). 
No Brasil, poucas instituições chegaram onde o Iphan chegou. De 1937 aos dias de hoje, muita coisa mudou. No Brasil e no Patrimônio. Nascido da mente privilegiada de intelectuais comprometidos com o futuro do País, o Instituto consolidou-se e fortaleceu-se com ações corajosas, amplamente reconhecidas e respaldas pela sociedade, conquistando legitimidade e a aprovação da população brasileira e, simultaneamente, protegendo um gigantesco conjunto de bens materiais e imateriais [...] (IPHAN, 2014).

Desse modo, o IPHAN, em conjunto com o Poder Público e com a comunidade, intensificou a promoção de preservar o patrimônio cultural brasileiro, por meio de inventários, registros, vigilância, tombamento, desapropriação e de outras formas de preservação. Isso demonstra a importância da valorização da preservação do patrimônio cultural como vetor no desenvolvimento sustentável, com a responsabilidade dos agentes públicos, juntamente com a participação e controle social na formulação e no acompanhamento de ações para proteger e promover o patrimônio histórico e artístico, material e imaterial. Assim, a autorização de valorizar e difundir o patrimônio cultural brasileiro por meio de ações que intentam sua preservação está exposta no artigo $5^{\circ}$, inciso LXXIII, da Constituição Federal, no capítulo referente aos direitos e deveres individuais e coletivos, quando expressa que "Qualquer cidadão é parte legítima para propor ação popular que vise anular ato lesivo ao patrimônio público ou de entidade de que o Estado participe [...]”.

Tal artigo demonstra o direito e o dever social para o patrimônio cultural e reafirma que o patrimônio social ocorre a partir da escolha da sociedade sobre aquilo que lhe é mais representativo. Porém, essa escolha necessita das relações sociais de determinado grupo, caracterizado como força hegemônica, com capacidade de mobilizar a maior parte da sociedade, ou toda ela, em torno da preservação do patrimônio cultural (Gramsci, 2001).

Uma vez que o grupo social valoriza e reconhece sua cultura, ocorre um desenvolvimento social por meio da identidade e do sentimento de pertencimento, podendo resultar em uma sensibilização para a preservação do patrimônio cultural (Belizio e Endres, 2016). Logo, o território pode ser o espaço ocupado por uma pessoa ou grupo, sendo aquele que possibilita uma experiência e uma existência. Já a manifestação cultural pode dividir ideologias, pelo fato de que uma sociedade define seus modos de comportamento, 
crenças, artes, costumes e hábitos, bem como caracteriza seu grupo social (Martins, 2003).

Assim, $o$ ato de preservar o patrimônio cultural passa a ser uma atividade consciente, vinculado ao compartilhamento de um território e pela aquisição da cultura. Por ser um fenômeno social, o patrimônio cultural pode mobilizar um grande fluxo de pessoas a se conhecerem e a se compreenderem, enquanto interagem nesses espaços compartilhados.

O patrimônio cultural de um povo permite distinguí-lo de outra comunidade, independentemente da delimitação de um território. Assim, a responsabilidade é de todos para zelar pela a manutenção e transmissão da cultura com a finalidade de preservar os bens culturais. Essa manutenção e transmissão pode promover uma preservação consciente por intermédio de ações promovidas pelo IPHAN, que têm sido realizadas por atividades de Educação Patrimonial, metodologia de ensino, desenvolvidas junto aos programas didáticos em instituições formais ou por ações informais da comunidade, visando à conservação dos bens e práticas culturais para atingir a socialização e a valorização da cultura local pela própria comunidade (Coelho, 2007).

A colaboração da comunidade na preservação do patrimônio cultural tende a ser cada vez mais importante, juntamente com o envolvimento da sociedade na política de preservação, que, muitas vezes, é proporcional ao grau de conhecimento e informação a que se tem acesso (IPHAN, 2014). A importância de proporcionar à comunidade meios de participar dessa ação pode ser efetivada pela interação mediante o processo educacional às demais dimensões da vida, auxiliando nas situações de aprendizagem com base no repertório cultural regional e local (Brandão, 1996).

O processo educativo não pode ser eliminado do desenvolvimento humano, ou seja, é uma das condições pelas quais o homem adquire seus atributos fundamentais, ao longo do processo histórico social. Dessa forma, é preciso que esteja inserido na história e no seu contexto social. No entanto, a herança cultural de um povo requer cuidados quanto ao uso e à divulgação, mesmo visando à sua conservação e preservação, pois são registros históricos e fator de identidade de um grupo social (Martins, 2004).

Mas pode-se dizer que é vital para a preservação dos bens culturais o contato diário da comunidade com os elementos de sua memória cultural, como garantia de reforço da identidade. A educação patrimonial pode fornecer uma experiência direta, por meio dos bens e fenômenos culturais, para se chegar a uma compreensão e valorização, por meio de um processo contínuo 
de descoberta, pois o meio ambiente histórico-cultural de uma sociedade oferece oportunidade de provocar sentimentos de surpresa e curiosidade, levando os membros desta a desejarem conhecer mais sobre eles mesmos (Belizio e Coelho, 2008, p. 64).

A educação deve possuir uma função fundamental para a sociedade, não só pela delimitação formal de conteúdos que devem ser seguidos e assimilados pelos alunos em uma instituição formalizada, a escola, mas ela deve ir além desse ambiente institucional formal, tendo em vista que faz parte da formação humana, sendo transmitida de geração em geração, pelo meio formal ou não. $\mathrm{O}$ processo de transmissão e assimilação do conhecimento e de habilidades deve visar à preparação dos indivíduos para uma ampla realidade social e, desse modo, irão se tornar agentes ativos na transformação da realidade (Libaneo, 1994), de tal modo que se torna necessário transmitir aos indivíduos conhecimentos e experiências culturais, para que esses se tornem aptos para transformar seu meio social.

É o homem, com sua conduta, seus comportamentos e atos, quem transmite seus conhecimentos por meio do ensino. O educador, por sua vez, tem a função de despertar o desejo do saber nos indivíduos (Osinski, 2002). No entanto, a educação deve se pautar no objetivo da sociedade e que esta necessita alcançar. Além do processo de socialização do saber elaborado, a sociedade busca um conhecimento pautado na compreensão de como o conhecimento é produzido e o sentido de fazer parte desse processo (Gandin, 1995).

Portanto, educação patrimonial visa à preservação do patrimônio cultural e denota a importância de ações para estimular a participação da comunidade no processo de conhecer as manifestações culturais locais para alcançar uma reflexão sobre a realidade em que está inserida; estimular diferentes processos educacionais, seja por meio do teatro, da dança, do cinema, da música, da literatura, das artes plásticas, da fotografia, dos desportos, além de espaços museológicos, casas históricas, praças e outros que possibilitem aprendizagem (Brandão, 1996).

Contudo, a educação patrimonial pode se tornar um instrumento para a alfabetização cultural, propiciando ao indivíduo uma leitura do mundo que o rodeia, levando-o à compreensão do universo sociocultural e da trajetória histórico-temporal do seu meio. Esse processo propõe o reforço da valorização da cultura brasileira (Horta et al., 1999). 
Para conseguir essa alfabetização cultural, existem alguns métodos didáticos, como as oficinas, atividades práticas, com etapas de observação e registro, pesquisa documental e atividades, que trabalham os conceitos de patrimônio, cultura, memória e identidade. De acordo com as Figuras 1 e 2, percebe-se que a atividade educacional deve ter um objetivo a ser seguido e um planejamento a ser executado na aplicação de uma metodologia de educação patrimonial, demonstrado a seguir:

Figura 1: 0 uso educacional do patrimônio cultural
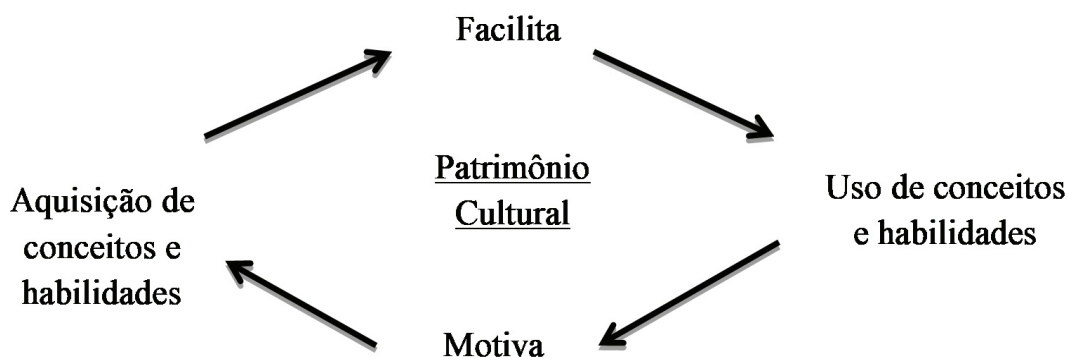

Fonte: Horta et al., 1999, p. 8.

Como demonstrado na figura 1 , o uso da metodologia na educação patrimonial necessita de um fluxo contínuo de motivação para a aquisição dos conceitos e das habilidades, para facilitar compreensão do patrimônio cultural e motivar a comunidade a se apropriar dos seus bens cultuais e dos conceitos sobre patrimônio cultural (Horta et al., 1999). 
Figura 2: Etapas metodológicas

\begin{tabular}{|c|c|c|}
\hline Etapas & Recursos/Atividades & Objetivos \\
\hline 1) Observação & $\begin{array}{l}\text { Exercício de percepção vi- } \\
\text { sual/sensorial, por meio de } \\
\text { perguntas, manipulaçãa, } \\
\text { experimentação, medição, } \\
\text { anotaçôes, comparação, de- } \\
\text { dução, jogos de detetive etc. }\end{array}$ & $\begin{array}{l}\text { Identificação do objeto/função/ } \\
\text { significado; } \\
\text { Desenvolvimento da percepção } \\
\text { visual e simbólica. }\end{array}$ \\
\hline 2) Registro & $\begin{array}{l}\text { Desenhos, descriçáo verbal } \\
\text { ou escrita, gráficos, fotogra- } \\
\text { fias, maquetes, mapas e plan- } \\
\text { tas baixas. }\end{array}$ & $\begin{array}{l}\text { Fixação de conhecimento percebi- } \\
\text { do, aprofundamento da observação } \\
\text { e análise crítica; } \\
\text { Desenvolvimento da memória, } \\
\text { pensamento lógico, intuitivo e } \\
\text { operacional. }\end{array}$ \\
\hline 3) Exploração & $\begin{array}{l}\text { Análise do problema le- } \\
\text { vantamento de hipóteses, } \\
\text { discussão, questionamento, } \\
\text { avaliação, pesquisa em outras } \\
\text { fontes como bibliotecas, } \\
\text { arquivos, cartórios, institui- } \\
\text { ções, jornais e entrevistas. }\end{array}$ & $\begin{array}{l}\text { Desenvolvimento das capacidades } \\
\text { de análise e julgamento crítico; } \\
\text { Interpretação das evidências e sig- } \\
\text { nificados. }\end{array}$ \\
\hline 4) Apropriação & $\begin{array}{l}\text { Recriação, releitura, drama- } \\
\text { tização, interpretação em } \\
\text { diferentes meios de expressão } \\
\text { como pintura, escultura, dra- } \\
\text { ma, dança, música, poesia, } \\
\text { texto, filme e vídeo. }\end{array}$ & $\begin{array}{l}\text { Envolvimento afetivo, internaliza- } \\
\text { ção, desenvolvimento da capacidade } \\
\text { de autoexpressão, apropriação, } \\
\text { participação criativa e valorização } \\
\text { do bem cultural. }\end{array}$ \\
\hline
\end{tabular}

Fonte: Horta et al., 1999, p. 11.

A figura 2 expõe as etapas metodológicas para auxiliar na elaboração de atividades para educação patrimonial, que tem o intuito de orientar o planejamento de uma atividade, seja em uma comunidade, seja em uma escola.

O projeto do IPHAN, aqui apresentado, de articular e executar a preservação do patrimônio cultural no país, com o apoio da comunidade e com ações para o desenvolvimento social, pode ser acessível quando a comunidade se apropria dessa ideia e a considera possível de se realizar. As metodologias de ensino, como os materiais metodológicos, demonstrados nas figuras $1 \mathrm{e}$ 2, ou os que estão disponíveis no site do IPHAN (www.iphan.gov.br), po- 
dem ser utilizados como materiais por quem desejar realizar uma ação de educação patrimonial, bem como servem de estímulo para promover a sensibilização na sociedade brasileira e para a importância de realizar ações de conscientização sobre a preservação do patrimônio cultural.

As articulações e os desafios encontrados na gestão cultural do IPHAN, a fim de proteger o patrimônio cultural do país, tornaram possível elaborar e disponibilizar essas estratégias de preservação para mobilizar a participação popular na preservação dos bens culturais do Brasil, como também foram úteis para exaltar a importância da cultura brasileira no desenvolvimento social e humano. Consequentemente, essa articulação incentiva a interação de grupos sociais em prol de um objetivo comum.

É fundamental que a sociedade se aproprie dos mecanismos disponíveis, como um vetor no desenvolvimento sustentável, na responsabilidade social, na participação popular e no controle social, já que os princípios de preservação do patrimônio cultural devem ser assimilados pela e para a sociedade brasileira. Desse modo, agir por meio das articulações e no material disponibilizado pelo IPHAN, realizando um trabalho educacional, com o objetivo de proteger os bens de caráter material e imaterial, torna possível conservar o patrimônio cultural do Brasil.

\section{Referências}

AMARAL, Adriana Facina Gurgel. Uma enciclopédia à brasileira: o projeto ilustrado de Mário de Andrade (dissertação). PUC-Rio, 1997.

BRANDÃO, Carlos Rodrigues. $O$ difícil espelho: limites e possibilidades de uma experiência de cultura e educação. Rio de Janeiro: IPHAN/ DEPRON, 1996.

BRASIL. Constituição da República Federativa do Brasil. Brasília, 1988. Disponível em: http://www.planalto.gov.br/ccivil_03/constituicao/ constituicao.htm. Acesso em: 20 set. 2017.

BELIZIO, Luciana de Aguilar e COELHO, Eva Regina Barbosa. "Estudo da aplicabilidade de uma proposta de educação patrimonial para o ensino fundamental no bairro Rosário/SM". In Anais do XII Simpósio de Ensino, Pesquisa e Extensão/SEPE, 2008. 
e ENDRES, Bruno Dellazzana. "Plano Nacional de Cultura enquanto política pública: uma análise das ações do Instituto do Patrimônio Histórico e Artístico Nacional na sua execução". In Anais da I Jornada de Ciência Política da Universidade Federal de Santa Maria, 2016.

CANANI, Aline Sapiezinskas Krás Borges. "Herança, sacralidade e poder: sobre as diferentes categorias do patrimônio histórico e cultural no Brasil”. Horizontes Antropológicos, v. 11, n. 23, pp. 163-75, Porto Alegre, jan.-jun. 2005.

COELHO, Eva Regina Barbosa. "A história e a etnografia na pintura mural de Aldo Locatelli no Rio Grande do Sul: uma oportunidade para a preservação da identidade gaúcha”. In Anais do I Congresso de Educação Arte e Cultura, 2007.

DUARTE, Newton (org.). Critica ao fetichismo da individualidade. Campinas: Autores Associados, 2004.

FAUSTO, Boris. História concisa do Brasil. São Paulo: EdUSP, 2002.

GANDIN, Danilo. Planejamento como prática educativa. 8 ed. São Paulo: Loyola, 1995.

GRAMSCI, Antonio. Cadernos do cárcere. Rio de Janeiro: Civilização Brasileira, 2001.

HORTA, Maria de Lourdes Parreiras et al. Guia básico da educação patrimonial. Brasília: IPHAN/Museu Imperial, 1999.

IPHAN. Educação patrimonial: histórico, conceitos e processos. Portal Iphan, Governo Federal, 2014.

LIBÂNEO, José Carlos. Didática. São Paulo: Cortez, 1994.

MARTINS, Clerton(org.). Turismo, cultura e identidade. São Paulo: Roca, 2003.

MARTINS, Lígia Márcia. "Da formação humana em Marx à crítica da pedagogia das competências”. In DUARTE, Newton (org.). Critica ao fetichismo da individualidade. Campinas: Autores Associados, 2004.

OSINSKI, Dulce. Arte, história e ensino: uma trajetória. 2 ed. São Paulo: Cortez, 2002. 


\title{
A teoria e a prática na formação de professores de Geografia na modalidade semipresencial
}

\author{
Anercilia Martins \\ Glaucio José Marafon \\ Vanilda Teófilo
}

\section{Introdução}

As significativas transformações que ocorrem neste início de século, que se materializam na hegemonia do modo de produção capitalista, na postura neoliberal, na existência de um Estado mínimo e na globalização financeira possibilitada pelas redes telemáticas, indicam como a realidade do mundo atual é dinâmica e complexa. Essas profundas e rápidas transformações são justamente as que ocorrem em um mundo onde estão a requerer um saber geográfico crítico, pautado em um núcleo epistêmico balizado pelos fundamentos do pensamento geográfico e pelo compromisso social do professor de Geografia em interpretar a realidade.

Torna-se necessário, nessa perspectiva, levar em consideração, além dos aspectos da formação do mercado de trabalho, outras dimensões que se abrem a partir do saber geográfico, sobretudo no exercício da crítica, da convivência com as diferenças, da expressão livre e criativa, do trabalho coletivo que valoriza as experiências sociais já consagradas, do estímulo às descobertas e às reflexões como condições indispensáveis à formação do cidadão.

Neste início de século, o mundo passa por um conjunto dinâmico de transformações que se articulam nas escalas local, regional e global - novas tecnologias são incorporadas à sociedade e, muitas vezes, resultam em novos recortes de espaço e tempo que afetam a vida cotidiana das pessoas.

A ciência geográfica, enquanto área do conhecimento, tem como meta identificar e analisar as escalas dessas transformações para, posteriormente, 
aplicar os resultados dessa investigação científica sistematizada à formação do professor de Geografia. Faz-se imprescindível apreender a noção de espaço geográfico, analisar a dinâmica de sua produção, o papel da sociedade nessa produção e na construção de sua trajetória, com a compreensão da realidade vivenciada.

Para entender o espaço, é necessário primeiro conhecê-lo e saber que, nesse processo, todos os homens se encontram incluídos, visto que, ao construirmos nossa história, estamos formando o espaço geográfico. Nesse sentido, ao estudarmos a Geografia, é necessário partir do mais real possível, do mais próximo possível, procurando entender a realidade tal como ela se apresenta, seja do ponto e sua estrutura, seja na perspectiva de sua informação. Entretanto, em cima dessa realidade, é preciso teorizar, isto é, compreendê-la como expressão local/regional do conjunto do território. É preciso buscar caminhos, saber ser participante e abrir/encaminhar alternativas (Callai, 1993, p. 31).

O estudo da natureza deve ser pautado pela dimensão social, ou seja, a partir do ser humano enquanto um ser histórico. O espaço físico faz parte da compreensão da própria realidade e do seu espaço. Os elementos naturais (relevo, solo, vegetação, clima, etc.) devem ser compreendidos no contexto em que vivem os homens, levando-se em conta o desenvolvimento tecnológico, e como são apropriados pela sociedade.

Destarte, é necessário que os alunos do ensino básico compreendam a Geografia como uma disciplina que os conduza a entender o mundo em que vivem e no qual todos são agentes na construção/transformação, pois "os programas de formação de professores cumprem um importante papel social, podendo contribuir para a inserção dos futuros professores na lógica da ordem social ou para promover a análise crítica da realidade com o objetivo de torna-lo melhor" (Rosa, 2006, p. 20).

Para atender a essa premissa, no curso de Licenciatura em Geografia, na modalidade semipresencial, encontram-se oito disciplinas de Teoria e Prática em Geografia, que, conjuntamente com as outras disciplinas do curso proporcionam, essa reflexão. Dessa forma, o objetivo deste ensaio é o de relatar a experiência na formação dos licenciados do curso da UERJ/CEDERJ. Será descrito como se procede ao longo do curso na busca da formação de um profissional de Geografia atento à formação cidadã dos futuros professores. 


\section{A formação de professores na modalidade semipresencial}

A implantação de um curso na modalidade semipresencial proporciona a interiorização da universidade e a inclusão de uma gama de alunos que têm a possibilidade de realizar um curso superior. $\mathrm{O}$ mapa a seguir expressa a origem dos alunos matriculados no segundo semestre de $2017^{1}$

\section{Procedência dos Alunos no Curso de Licenciatura Geografia UERJ/CEDERJ 2017}

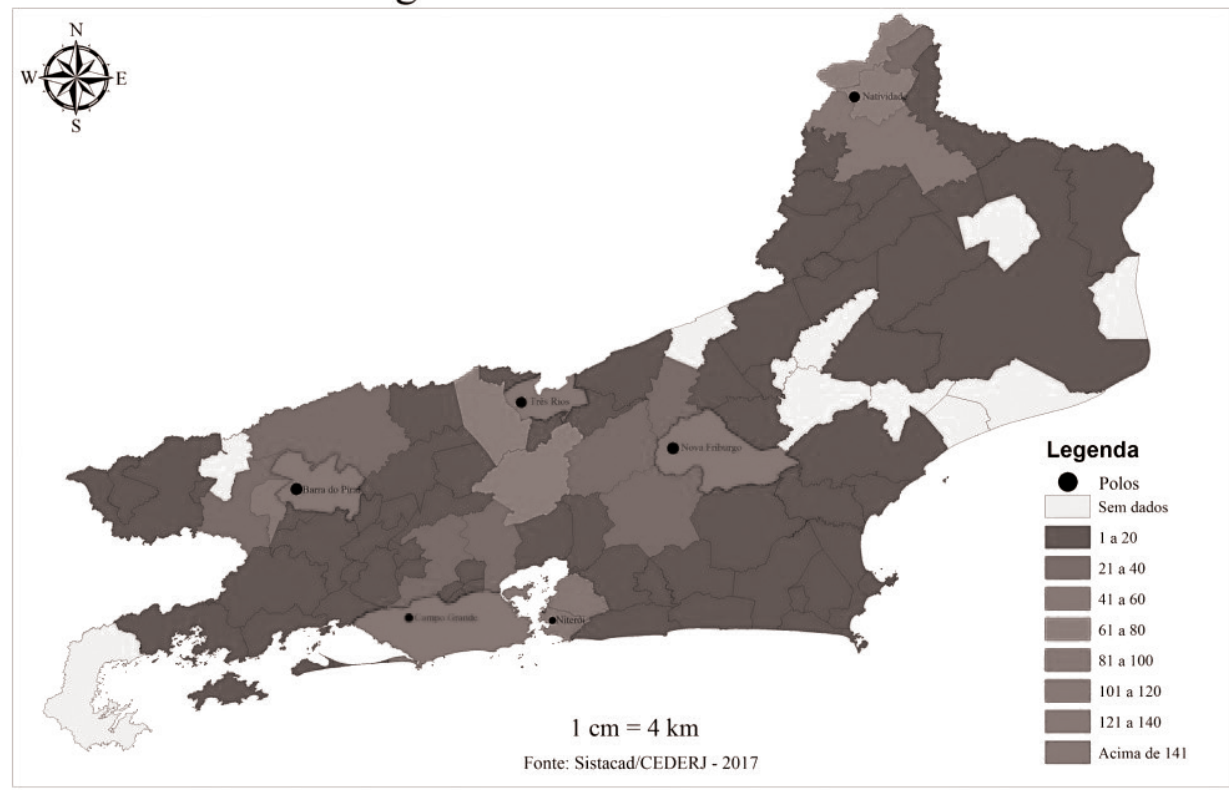

Destacamos que a origem dos alunos se vincula a praticamente todos os municípios do estado do Rio de Janeiro, com destaque para os municípios onde os polos que servem de suporte aos alunos do curso de Geografia estão localizados. Ainda que a Região Metropolitana apresente vários cursos presenciais em IES públicas e privadas, observa-se o elevado número de alu-

\footnotetext{
${ }^{1} \mathrm{O}$ curso de Licenciatura em Geografia é ofertado pela UERJ, no âmbito do Consórcio CEDERJ (Centro de Educação Superior a Distância do Estado do Rio de Janeiro), que é formado por sete instituições públicas de ensino superior - CEFET, UENF, UERJ, UFF, UFRJ, UFRRJ e UNIRIO -, e conta, atualmente, com mais de 45 mil alunos matriculados em seus 15 cursos de graduação a distância.
} 
nos dela oriundos. Isso se explica pela alta concentração populacional na região, pois cerca de $75 \%$ da população fluminense apresenta domicílio nela. Existem, em menor número, alunos oriundos dos estados vizinhos, tais como Minas Gerais e Espírito Santo. O perfil desses alunos remonta a um grupo com faixa etária mais elevada e que exerce atividades profissionais. Destarte, o curso na modalidade semipresencial proporciona uma oportunidade de formação em nível superior.

Assim, o aluno do curso de Licenciatura em Geografia, nessa modalidade, tem à disposição, para seus estudos, cadernos didáticos, guias de orientação, aulas na web (plataforma), tutorias presenciais (nos polos) e tutorias a distância (fóruns e chats), além de atividades presenciais (avaliações, trabalhos de campos, semanas acadêmicas etc.). Esse conjunto de atividades proporciona a interação do aluno com os conteúdos e com professores e tutores para esclarecimento das dúvidas e reflexões sobre os temas propostos nas aulas.

$\mathrm{Na}$ busca de sentido, em função das múltiplas experiências vividas no ensino presencial, percebemos que trabalhar com a educação, qualquer que seja a modalidade, é um exercício constante de formação e, nessa direção, podemos afirmar que os saberes construídos e cultivados com uma grande quantidade de professores da escola básica e da universidade resultaram na luta pela conquista de condições que possam transformar a educação pública em inclusiva.

Vivemos num contexto marcado pelo inusitado e não mais pela lógica, trazendo um novo horizonte de incertezas, em função das constantes inovações que suscitam demandas que se renovam face às exigências de um mundo em estado de tensão entre a cultura objetiva e a subjetiva, do qual nos fala Milton Santos (1997). Nesse mundo, os saberes e os atributos crescem complexificando o perfil do profissional que necessita de novas habilidades, especialmente novos olhares para os antigos problemas (Teófilo, 2007).

Nessa perspectiva, urge a necessidade de uma formação sintonizada com os desafios que nos coloca a educação contemporânea, como, por exemplo, o da informação. A questão que se apresenta de imediato é que o importante não é acessá-la em grande quantidade, mas identificar qual informação se torna mais importante na quase infinidade em que se encontra disponível.

Bem sabemos que o emblemático sinal de um projeto de inclusão passa necessariamente pelo respeito às singularidades, particularidades e experiências daquele a que se destina. Esse novo paradigma pressupõe a criação de 
estratégias que apoiem a inserção social em que as experiências inclusivas deverão ser estimuladas e implementadas nos espaços educativos.

Sem sombra de dúvida, uma forma de aprendizado e de ensino que permita o acesso crescente a oportunidades de aprendizado, projetando processos de aprendizagem e de ensino à altura dos desafios atuais, torna a educação à distância uma área extremamente instigante e desafiante. Entendemos a EaD como sistêmica e com um caráter multidisciplinar em que um conjunto de partes opera de forma integrada, favorecendo o processo de ensino e aprendizagem à distância; além disso, o aprendizado não acontece de forma acidental, ao contrário, requer planejamento e técnicas específicas, ocorrendo fora dos espaços convencionais de ensino, considerando-se que a comunicação se dá por meio de diferentes tecnologias.

Se concordarmos com Mattar (2014), ao dizer que a modalidade à distância descortinou um universo de possibilidades para a educação, tendo os avanços tecnológicos como um aliado dessa empreitada, vamos facilmente entender que foram eles que favoreceram a utilização das mais diferentes mídias como recurso pedagógico e que esse uso ajuda, sem dúvida, na construção de uma nova concepção de ensino e de aprendizado.

Foi por esse caminho que conseguimos ver um tipo de movimento necessário e possível à prática docente: um educador que recupera as tarefas pedagógicas procurando compreender o papel sociopolítico da educação e dos espaços educativos.

Há de se considerar que um tutor educador competente não é mais o que apenas domina o saber de sua disciplina, mas aquele cuja competência reside também na preocupação com a apreensão do conhecimento pelos alunos. Estamos pressupondo que existam novas perspectivas, novos recursos a serem acessados, buscando outros que permitam trabalhar. Aqui, já podemos afirmar que a convivência com as diferenças sempre representou um desafio para nós. Por essa razão, temos que unir esforços no sentido de "caminharmos e avançarmos em outras dimensões, especialmente as humanas e sociais" (Linhares, 2002, p. 117).

Em nossas práticas, procuramos caminhar na contração dos modismos pedagógicos, muitas vezes rapidamente absorvidos, sem qualquer crítica, por parte daqueles que os adotam, buscando desenvolver uma linha consistente de trabalho, conforme nos ensina Mello (1998, p. 53) - uma questão que nos coloca, de imediato, diante do grande desafio de encontrar uma interlocução possível que permita olhar para os processos de aprendizagem e de ensino à 
altura dos desafios atuais, quando é sabido que pouco se vem cogitando acerca da construção do conhecimento (Teófilo, 2007).

É importante salientar que o advento da pós-modernidade trouxe constantes mutações e transformações para a sociedade, apresentando um horizonte de incertezas, com reflexos nos mais diferentes aspectos da vida humana. O principal impacto foi o descentramento do sujeito cartesiano - isso desencadeou um novo olhar da ciência para a realidade cultural dos sujeitos, propondo uma tolerância de caráter sócio-histórico dos processos cognitivos e o direito à identidade cultural. É evidente que isso criou uma revolução nos estudos sobre a mente humana, com significativas repercussões nos espaços educativos, que nem sempre acompanharam tais mudanças.

Para deslocarmos da concepção de sujeito cartesiano racional e consciente, situado no centro do conhecimento, para uma concepção social, na tentativa de reconhecermos também o sujeito social, não só o cognitivo, achamos por bem nos apropriarmos de um outro quadro teórico que nos permitisse dar conta, de forma mais satisfatória, de incluir o maior número possível de alunos que pudessem acessar o saber científico.

Sentimos a necessidade, enquanto profissionais que atuam na EaD, de nos apropriarmos de um outro quadro teórico, pois uma vez trabalhando com a educação a distância, temos de deslocar uma unidade teórica para a multiplicidade de saberes, o que exige uma prática docente reflexiva, alicerçada em um entendimento e uma compreensão de mente e de saber que considerem a heterogeneidade, uma concepção de sujeito social que precisa acessar o saber científico.

Trabalhar com a EaD é atuar com as diferenças, e isso significa levar em consideração o significado e o sentido dos valores culturais dos nossos aprendizes licenciandos, tomando-os como objetos de conhecimento específicos, que influenciam o processo educativo formal e que são referenciais concretos, via única de compreensão dos conhecimentos a serem abordados e trabalhados nas salas de tutoria.

O sistema de tutoria tem sido fundamental no processo de ensino-aprendizagem, e, nesse sentido, tem sido feito um investimento para que o tutor construa um pensamento inclusivo, pensando numa outra lógica para o curso de formação de professores de Geografia. Tal lógica é diferente daquela a que estamos acostumados e que tem gerado o descrédito dos agentes educativos, uma prática que vem buscando uma melhor compreensão das variáveis que incidem direta ou indiretamente nas nossas práticas marcadas pelo respeito 
à pluralidade, o que implica buscar fatores para além das fronteiras da universidade. Além dos cursos de formação, mais técnicos, proporcionados pelo consórcio CEDERJ, a equipe de coordenação do curso possibilita, em encontros regulares, uma formação complementar para que os tutores possam desempenhar seu papel de forma a contribuir na formação dos licenciandos.

A partir dessas preocupações, foi traçada uma metodologia que expressa a ideia de uma transposição didática e que veio a se constituir formalmente no nosso foco de trabalho.

A transposição didática de que nos falam autores como Perrenoud (1993, p. 25), Chevallard (1998) e Almeida (2011) foi por nós assumida e entendida como a possibilidade de encurtar o caminho entre o conhecimento científico e o conhecimento desenvolvido nos espaços educativos, pois o distanciamento entre teoria e prática inviabiliza a possibilidade de entender o espaço educativo como um espaço de construção, articulador de diferentes conhecimentos, onde a teoria ancora uma prática diariamente refletida num movimento dinâmico e contínuo de construção e reconstrução (Teófilo, 2007).

Antes da descrição propriamente do trabalho realizado nas disciplinas de Teoria e Prática Geográficas (TPGs), ressaltamos que as estratégias são implementadas de forma processual, sendo pensadas, repensadas e reestruturadas ao longo do percurso e levando em consideração as características específicas dos alunos e do contexto dos licenciandos (Almeida, 2011).

É possível afirmar que o trabalho desenvolvido no curso de Geografia exprime a ideia sugerida por Almeida (2011, p. 25) de que é preciso "edificar uma concepção própria de transposição didática”. Concebemos o educador (tutor) e o aluno (licenciando) como construtores de uma pluralidade de saberes e pesquisadores de sua prática, procurando implementar práticas significativas e inovadoras.

\section{A teoria e a prática na formação dos profissionais de Geografia no curso semipresencial da UERJ/CEDERJ}

O grupo de Teoria e Prática Geográficas tem se esforçado em busca de uma revisão constante dos seus princípios, fundamentos e práticas, trabalhando com a pedagogia dialógica, a caminho da concretização de um projeto que acreditamos ser verdadeiramente inclusivo. 
A disciplina Teoria e Prática em Geografia é oferecida em todos os períodos do curso e pretende realizar a transposição entre o saber teórico oferecido pela universidade e a prática do docente em sala de aula. Como a disciplina é disponibilizada nos oito períodos regulamentares do curso, há uma sequência na apresentação de suas atividades, de acordo com o nível de aprendizagem que se espera para o graduando em cada fase de sua vida acadêmica.

Para Mattar (2014, p. 23), o que determina o sucesso ou o fracasso de projetos de EaD ocorre em função "do público-alvo, do desenho pedagógico do curso, das atividades propostas e de outras variáveis”. À medida que o curso foi se desenvolvendo, foram sendo implementados e disponibilizados diferentes recursos.

Entendemos "recursos" como meios tecnológicos lançados pelo educador, objetivando complementar e, portanto, facilitar o processo de construção do conhecimento. Trata-se de um componente do ambiente de aprendizagem que exige conhecimento técnico e pedagógico do educador, uma vez que funciona como um estímulo à aprendizagem, tendo uma função, sem dúvida, de extrema importância.

Nas disciplinas de Teoria e Prática em Geografia, nossa preocupação na escolha dos mecanismos alicerça-se na concepção de que tenham um potencial comunicativo e interativo, considerando-os como verdadeiro suporte à aprendizagem, visto serem "material de apoio ao processo" de construção do conhecimento (Gouvêa e Oliveira, 2006, p. 86).

Atividades desenvolvidas em EaD e seus recursos, por meio da Plataforma Moodle:

\begin{tabular}{|c|c|}
\hline Discussão de textos & Por meio de fóruns \\
\hline Leitura de textos & Individual, com possibilidade de comentários \\
\hline Videotutorias & $\begin{array}{c}\text { Possibilidade de interação entre tutor e alunos de polos } \\
\text { diferentes }\end{array}$ \\
\hline Atividade on-line & $\begin{array}{c}\text { Desenvolvimento da articulação de comentários a partir da } \\
\text { análise de textos }\end{array}$ \\
\hline Produção de textos & Mediante envio de arquivos \\
\hline
\end{tabular}


Sem sombra de dúvida, um recurso adequado propiciará a interação propugnada por Piaget (1998) ou o auxílio à formalização dos conceitos, como nos ensina Vygotsky (1986), viabilizando o acesso à informação e criando, assim, um espaço descrito por Levy (1998) como ciberespaço, em que tutores e alunos "interagem, cooperam e aprendem juntos" (Valente e Moran, 2011, p. 24).

Todavia, quando olhamos para nossa experiência com os alunos em sala de tutoria, constatamos que temos ambientes ricos em aprendizagem, onde procuramos inovar, testar e experimentar, com materiais elaborados, tais como links, texto de apoio, além de uma estrutura física nos polos - bibliotecas e laboratórios - e encontros com tutores presenciais para reflexões acerca dos conteúdos veiculados nas diferentes disciplinas.

A articulação desse saber acadêmico/científico nem sempre é de fácil entendimento, principalmente quando o docente leciona nos anos iniciais do segundo segmento do ensino fundamental, no qual o aluno não está preparado para a aquisição de conhecimentos de forma meramente abstrata. Desse modo, ancoramo-nos nos estudos de Piaget.

Bem sabemos que esse pensador foi um dos estudiosos da questão da origem e formação da gênese do conhecimento, sendo inegável sua contribuição no sentido de melhor fundamentar as práticas pedagógicas - sua visão de aprendizagem e de desenvolvimento e a forma como esses dois processos interagem interessaram-nos sobremaneira, cabendo destacar alguns conceitos significativos dessa matriz conceitual, a qual procuramos utilizar em nossa prática docente.

Diante dessa visão, podemos inferir que as atividades lúdicas, concretas e, de certa forma, sequenciais devem ser apresentadas e trabalhadas de modo diferenciado, tendo em vista o perfil dos licenciandos. Temos, como exemplo, o trabalho desenvolvido sobre a percepção do espaço, que exige como pré-requisito o conhecimento da percepção de vizinhança.

Partimos, então, propondo atividades que respeitem os recursos estruturais dos alunos, a fim de lhes permitir a assimilação dos conteúdos, com a preocupação de que façam sentido. Para tanto, nosso ponto de partida é a realidade do aluno (conhecimento empírico), caminhando em direção à construção dos conceitos (conhecimento conceitual) (Ramozzi-Chiarottino, 1992).

Nosso objetivo, a partir desse momento, é apresentar a metodologia trabalhada em cada uma das etapas. 
A primeira etapa (TPG I) objetiva levar o graduando a se aproximar do conceito de transposição didática, fazendo com que construa a relação teoria/ prática por meio da realização de um trabalho a ser enviado pela plataforma de ensino Moodle. Os artigos acadêmicos são apresentados, e sugere-se a leitura de revistas vinculadas a sua área de estudo. Procura-se, nesse momento, mesmo que de um jeito informal, desenvolver um arcabouço teórico neste licenciando que acaba de concluir a Educação Básica ou que está se reintegrando, após alguns anos de afastamento do sistema de ensino.

O estudo do meio torna-se nosso principal tema, e procuramos enfatizar para o futuro docente sobre a necessidade de trabalhar com a realidade do educando. Nesse momento, ancoramo-nos em Costella e Schäffer (2012, p. 53), que afirmam:

O estudo do lugar e o discernimento, pelo aluno, de que pertence a ele favorecem a compreensão de sua identidade. Um aluno é único, mas ao mesmo tempo, é o resultado de suas relaçóes. Ele se reconhece quando compreende o que o envolve, as relações ali presentes e o processo, a continuidade do lugar. Quando, em sala de aula, insistimos em ensinar Geografia sem reconhecer a geografia do lugar do aluno, sacrificamos uma fase do reconhecimento de relações.

Tomamos como ponto de partida os conhecimentos veiculados nas disciplinas iniciais do curso, como Climatologia Geográfica, Geologia Aplicada à Geografia, Cartografia Básica e Espaço, Natureza e Sociedade, vinculando-as ao estudo do meio, ou seja, ao ambiente de vivência e convivência, trabalhando com a noção de lugar, espaço e tempo, o que nos permite vivenciar a "transposição didática” (Chevallard, 1998).

Corroborando com Costella e Schäffer (2012), faz-se importante o processo de alfabetização cartográfica para que possa realizá-lo com o discente. As noções de espacialidade, ao se trabalhar com a disciplina Cartografia, são apresentadas, e procura-se também levar o graduando a pensar sobre a importância do estudo do meio (local) em consonância com o meio tecnológico, em que o lugar se relaciona com o global e suas representações.

Como proposta de atividade para a presente etapa, o graduando deve montar uma atividade com as disciplinas do período em que o conteúdo acadêmico apresentado possa ser utilizado em suas aulas, por meio de um 
planejamento no qual são elencados objetivos, conteúdo, material didático, desenvolvimento/metodologia e avaliação.

A segunda etapa (TPG II) apresenta o trabalho de campo como fator primordial no ensino de Geografia, visto que, ao se pensar o espaço - ambiente de mutações e embates sociais -, há necessidade de o aluno "viver" o que está sendo estudado. A partir desse contato, abre-se a possibilidade de formar cidadãos críticos, com potencialidades para análise de forma concreta/real. As atividades de campo poderão facilitar a aquisição de conhecimentos referentes a diferenciadas facetas da Geografia física ou humana, revelando-se, assim, uma estratégia pedagógica de excelência para desenvolvimento da aprendizagem. A proposta apresentada nessa fase utiliza-se dos conhecimentos veiculados nas disciplinas de Geomorfologia Geral, Geografia do Ciberespaço e Geografia da População.

Com base nas disciplinas elencadas, propõe-se ao graduando que, a partir de uma atividade de campo realizada em seu próprio município, ele elabore um roteiro que possa ser trabalhado com alunos do segundo segmento do ensino fundamental ou médio. Esse roteiro deve possuir algum tipo de representação cartográfica, e o formato do texto já deve estar como o de um pequeno artigo acadêmico. Objetivamos, nessa fase, iniciar a construção da formação do professor/pesquisador.

Como nos ensina Piaget, conhecer significa organizar, estruturar e explicar, mas isso a partir do vivenciado (experimentado). Essa é, sem dúvida, a questão fundamental dessa teoria. Conhecer não implica tão somente explicar ou viver, mas é um processo que tem como ponto de partida a vivência, a experimentação (uma ação sobre o objeto do conhecimento).

Ainda nessa perspectiva, para Marafon (2015): "o trabalho de campo, como técnica de análise, pode ser realizado em qualquer paisagem, seja rural ou urbana, e utilizado para a obtenção de informações sobre a importância das relações".

Ancorados na perspectiva da teoria piagetiana, não basta explicar como se dá o conhecimento de um adulto, mas também perceber as condições necessárias para que se chegue ao conhecimento, que depende, basicamente, da ação recíproca organismo-meio, em que as trocas são responsáveis pela construção da própria capacidade de conhecer; sem elas, essa capacidade não se constrói, não ocorrendo, portanto, mudança de comportamento (Enderle, 1987).

$\mathrm{Na}$ terceira etapa (TPG III), apresentam-se os recursos didáticos, e procura-se estabelecer as diferenças entre tais recursos e metodologias/procedi- 
mentos, pois há uma tendência de confundir o que é a prática do educador com o instrumento pedagógico a ser utilizado.

A partir de conhecimentos anteriores e leituras propostas sobre o tema - recursos didáticos, sua importância e utilização - e supondo que o licenciando já o tenha assimilado a conceitos pedagógicos, solicitamos que seja construído um texto acadêmico.

Resgatando os conceitos de Piaget, é possível constatar, nessa etapa, os dois processos que se complementam na aprendizagem; a saber: assimilação e acomodação. A assimilação ocorre quando o aprendente imprime uma determinada ação para solucionar uma dada situação-problema e utiliza-se de uma estrutura mental já formada, e, portanto, a nova situação é incorporada e assimilada a um sistema já pronto. Trata-se de um repertório comportamental ou mental que se atualiza para dar conta de uma circunstância.

Já a acomodação ocorre quando, ao tentar solucionar determinada situação-problema, o sujeito se utiliza de uma estrutura mental que já possui, mas um novo elemento é adicionado, incorporado e, em consequência, assimilado àquela estrutura até então existente, atualizando seu repertório comportamental ou mental em uma situação determinada.

Nesse momento, enfatizamos também o uso de novas tecnologias e o trabalho de forma interdisciplinar com as variadas linguagens. Temos, como exemplo, as experiências que podem ser realizadas de forma concomitante ao ensino de Biologia ou Química, ao se trabalhar com conteúdos voltados à área de pedologia. Outros exemplos são as charges, histórias em quadrinhos ou dramatizações com auxílio de professores de língua portuguesa ou artes.

Nessa fase, as disciplinas do curso enfatizadas são: Geomorfologia Continental, Geografia da População do Brasil e Geografia Agrária. O objetivo, nesse processo, é destacar o papel do docente como mediador e não apenas como apresentador e expectador.

É interessante frisar que não há crítica à apresentação de aulas com recursos dinâmicos dos slides ou ao desenvolvimento da pesquisa e à autonomia estudantil, pois sabe-se que, na realidade da sala de aula, o docente assume variados papéis. O que se destaca e se incentiva nesse momento é a necessidade de apropriação dos diferentes recursos a serem utilizados.

Ao enfatizar o uso de recursos didáticos variados e a importância das novas tecnologias, há uma preocupação de que o licenciando tenha percepção das diferentes realidades encontradas nas instituições de ensino e, assim, possa fazer suas adaptações e também ser capaz de realizar suas produções. Para 
Mello e Angeloni (2014, p. 789), “no entanto, a sala de aula é o espaço que o professor tem para contribuir no esforço coletivo dos educadores que se preocupam em buscar uma educação que seja capaz de superar seu caráter reprodutivista”.

Recorremos, novamente, à construção do conhecimento em Piaget, que nos ensina que a adaptação é resultado dos processos complementares de assimilação e acomodação. Eles estão presentes em todas as nossas ações durante a vida e dificilmente ocorrem em separado, pois nunca uma situação ou objeto é exatamente igual a outro(a) já conhecido(a).

A análise do livro didático é realizada na quarta etapa - sua utilização traz percepções bem diferenciadas, principalmente quanto ao seu real objetivo e sobre a adaptação aos currículos dos estados e municípios. Reforçando esse aspecto, Pontuschka et al, (2009, p. 343) afirmam que "O Brasil é um país de grande extensão territorial constituído por realidades e culturas muitos diferentes, que os conteúdos do livro didático não têm condições de abarcar”.

Reforçamos, nessa etapa, o papel do livro didático como instrumento auxiliar ao processo de ensino-aprendizagem, pois, como sinaliza o MEC nos guias sobre os livros didáticos, avaliados e disponibilizados para os professores, eles podem servir como material didático de apoio e não como guia para o trabalho com os alunos. Destarte, o livro didático serve como um suporte aos professores e alunos no trabalho com os temas de Geografia. Baseados nas fichas de avaliações de tais livros e disponibilizados nos guias, orientamos os alunos a efetuarem uma análise das obras para que façam uma escolha consciente e técnica do livro adequado às suas necessidades como profissional de geografia.

Nesse contexto, a disciplina traz como proposta a análise de capítulos de livros didáticos após estudos embasados em obras de autores que já tenham baseado sua vida acadêmica na temática. Propomos ao graduando que apresente, inicialmente, as diferentes abordagens e que, após a escolha de um livro, entre os anos de escolaridade (segundo segmento do ensino fundamental e do ensino médio), realize uma análise sobre a apresentação dos conteúdos de uma das disciplinas do $4^{\circ}$ período.

A referida análise deve ser pautada também Plano Nacional do Livro Didático (PNLD), com ênfase nas disciplinas que estão sendo veiculadas no período em questão. A saber: Geografia e Sensoriamento Remoto, Geografia Econômica e Geomorfologia Costeira. 
A quinta etapa (TPG V) refere-se ao trabalho com representações, que se apresenta como arcabouço necessário para a construção da noção de espaço. As atividades cartográficas devem ser enfatizadas desde o início do processo de aprendizagem, levando-se em consideração a leitura que cada educando faz da paisagem. Aprender a "ler" e interpretar o espaço geográfico faz parte do processo de desenvolvimento crítico-social, e a referida leitura pode ser estimulada de formas diferenciadas, enfatizando-se, mais uma vez, os anos de escolaridade do educando. Nessa fase, é importante que "ao refletirmos sobre o espaço de representação na escola podemos vislumbrar diversas perspectivas, como: a representação espacial construída pelos educando e educadores" (Kozel Teixeira, 2006, p. 1).

"A leitura pode partir de imagens e mapas dos locais do mundo confrontando com o local, mas também pode partir da análise do espaço concreto e próximo" (Callai e Andreis, 2013, p. 11). Nessa fase, priorizamos a produção de um artigo, tomando prioritariamente como referência o município do licenciando, ou seja, o estudo de alguma área e as respectivas representações.

Na sexta etapa (TPG VI), propomos aos licenciandos a construção de um projeto didático que tome como ponto de partida a sua vivência escolar. O graduando, ao analisar a escola onde realiza o estágio supervisionado, verifica as reais possibilidades para o desenvolvimento de um projeto a partir de uma problemática existente e tendo como foco as disciplinas cursadas no período. Também sugerimos a eles a articulação, no projeto, de atividades que despertem o interesse do educando, pois, como nos ensinam Rego et al. (2007, p. 44), "os ensinos fundamentais e médios devem ser acima de tudo, desafiadores, capazes de despertar o interesse dos alunos para a resolução de problemas que a vida apresenta”.

Neste momento, não é nossa intenção desenvolver uma análise exaustiva acerca da teoria de Vygotsky (1989, 1991, 1992), e também não pretendemos trazê-la aqui como u ma contraposição à teoria piagetiana, mas é com base nas suas concepções que pretendemos trazer a importância do meio na estruturação das condutas do sujeito e na formação do conhecimento, aspectos que assumiram um lugar de destaque na teoria.

Nessa etapa da disciplina, chegamos ao processo de formação e de construção dos conceitos e, com base nesse teórico, encontramos as explicações acerca de como eles se transformam ao longo do desenvolvimento: de início, a linguagem se apresenta como um meio de comunicação entre as pessoas, à medida que o sujeito vai se desenvolvendo, o pensamento vai se organizando, 
chegando a se tornar uma função mental interna. Os significados fornecidos pelo grupo ao qual pertence vão sendo internalizados, pelo sujeito nas trocas, e, por meio das interações sociais, o mundo (a fala) exterior se converte em interior (Vygotsky, 1991).

Aprendemos com Vygotsky que a construção e o desenvolvimento dos conceitos é um processo longo - não linear e muito menos simples -, e sua trajetória genética aponta para duas raízes independentes que mais tarde se cruzam e se unem num momento avançado do desenvolvimento, emergindo desse processo qualitativo os "conceitos genuínos" (Oliveira, 1992), que envolvem um sistema de relações e generalizações (contidas nas palavras) que ocorrem nas trocas entre o homem e a cultura.

Assim, o que importa na presente discussão é que, para essa teoria, é a cultura que baliza as condições de aprendizagem dos sujeitos: "os sujeitos aprendem e se desenvolvem nas relações produzidas numa determinada cultura" (Oliveira, 1992) e não como se pensava, ou ainda se pensa, ou seja, por meio de um discurso unificador.

Se levarmos em conta o fato de que o aprendizado desperta vários processos internos de desenvolvimento, porque se inicia muito antes do ingresso do aluno na vida escolar, e se tomarmos como ponto de partida que "qualquer situação de aprendizagem com a qual nos defrontamos no espaço escolar tem sempre uma história prévia” (Vygotsky, 1991, p. 93), essas considerações indicam o quanto se torna infrutífera "a ideia de que se aprende algo de forma rápida e mecânica - concepção pregnante nos espaços educativos” (Teófilo, 2007, p. 142).

Nessa direção, a hipótese de que os conceitos científicos e espontâneos não se desenvolvem em direção contrária, mas se interconectam ao longo do desenvolvimento, ganha relevância para nosso trabalho, porque corrobora afirmativas anteriores, quando sinalizamos que o educador, para desempenhar bem o seu papel, terá de desafiar a construção de novos conhecimentos, necessitando tomar os conceitos espontâneos, do cotidiano (o que o aluno já sabe) como ponto de partida.

Uma outra perspectiva que se abre com essa teoria e que nos permite estabelecer uma relação com a nossa prática docente refere-se à oportunidade de um redirecionamento de nosso olhar para os alunos como ativos e interativos no seu processo de conhecimento. O saber é compartilhado nas relações estabelecidas entre o sujeito e o objeto do conhecimento - princípio confirmado 
na nova direção do social para o individual, criando um modelo de ação comunicativa pura (Chaui, 2002).

É nessa perspectiva que procuramos redimensionar os conceitos científicos, mudando-os de papel e de lugar, enquanto ampliadores de novas competências, visto que, interconectados com os conceitos espontâneos (do cotidiano, da experiência), passaram a indicar uma prática que, como ressaltada algumas vezes, procura se alicerçar em um novo entendimento de sujeito, de educação, de desenvolvimento e de aprendizagem.

A sétima etapa (TPG VII) traz como proposta a produção de um projeto de pesquisa. Entendendo o espaço da tutoria como um espaço de formação e movidos pela questão da relação entre o educador e a pesquisa, chegamos ao conceito de "professor-pesquisador", inspirados em Schön (1983), o precursor da ideia de "professor-reflexivo".

Parece clara a articulação pesquisa e formação apontada por Ludke (2001), uma constatação que vem exigindo uma busca por caminhos que ajudem a melhorar a ação docente, em uma reflexão contínua sobre as práticas desenvolvidas nos diferentes períodos dessa disciplina.

Argumenta-se, nesse momento, sobre a necessidade do professor como pesquisador e o desenvolvimento de sua autonomia, pois "apesar da importância dessa questão, persiste ainda a ideia de que o professor da escola básica não necessite pesquisar" (Pontuschka et al., 2009, p. 96).

Propondo ao licenciando um trabalho com estrutura dialógica e colaborativa no contexto de uma prática reflexiva - acreditamos ser esse, sem dúvida, um caminho de formação de um futuro educador reflexivo -, direcionamos o projeto de pesquisa para o tema do trabalho de conclusão do curso, visando demonstrar para o licenciando que "investigar é pesquisar e que a pesquisa deve desenvolver o aprender a pensar" (Pontuschka et al., 2009, p. 96).

Na etapa final (TPG VIII), objetiva-se a produção de um artigo acadêmico cuja temática se baseie no currículo mínimo e em sua articulação nas redes de ensino (estadual e municipal). Procuramos desenvolver uma discussão embasada na análise histórica do currículo de Geografia, perpassando pelas variadas fases, como a Lei de Diretrizes e Bases da Educação n. ${ }^{\circ}$ 5.692, em 1971, que dava ênfase aos estudos sociais. A partir desse momento, procuramos verificar as abordagens realizadas com os movimentos de renovação da Geografia e com relação às diretrizes dos Parâmetros Curriculares Nacionais. 
O aluno deverá fazer uma análise crítica sobre a proposta curricular do estado do Rio de Janeiro, focando nos anos de escolaridade dos ensinos fundamental e médio.

A perspectiva aqui defendida é a de que tanto o licenciando como o tutor educador são sujeitos do conhecimento e, portanto, produtores de saberes produzidos no espaço de tutoria, e são eles que vão permitir ao profissional de educação aperfeiçoar suas práticas.

Vimos com Tardif (2002, p. 223) que as competências profissionais estão diretamente ligadas às "capacidades dos licenciandos/alunos de racionalizar suas próprias produções, de criticá-las, de revisá-las e de objetivá-las”.

Esse encaminhamento no processo de formação de professores está em consonância com a perspectiva seguinte: "o primeiro ponto é colocar o aluno como centro e sujeito do processo de ensino, para a partir daí refletir sobre o papel do professor e da Disciplina, que são elementos igualmente integrados no contexto didático" (Cavalcanti, 2006, p. 33).

No processo avaliativo, considera-se a preocupação em criar um procedimento que tomasse como ponto de partida a reflexão acerca do lugar que a avaliação deve ocupar na modalidade a distância, não perdendo de vista que é a "relação intrínseca entre avaliação e aprendizagem o que, certamente, impõe-nos a busca de uma coerência entre ambas" (Teófilo e Filho, 2013, p. 185).

Para tanto, a preocupação em veicular conhecimentos significativos, ou seja, aqueles de extrema importância e relevância para os alunos, tem sido a tônica do trabalho, entendendo a equipe de tutores e coordenação que tanto o conteúdo quanto a forma como vêm sendo disponibilizados devem ser sistematicamente avaliados.

Tomando como premissa básica que "avaliar é para agir" (Perrenoud, 1999, p. 32), uma solução interessante encontrada e que vem trazendo um resultado eficiente e eficaz é o trabalho com o aluno no sentido do estímulo à compreensão dos textos, à escrita nas normas acadêmicas e às atividades que permitam a ele se expressar e produzir conhecimento a partir da sua realidade, pois:

o desenvolvimento de um modo de pensar geográfico mais amplo e abstrato requer, portanto, a formação de conceitos pelos alunos. $\mathrm{O}$ trabalho com o conteúdo geográfico, para que ele se torne ferramenta do pensa- 
mento, implica a busca de significados e sentidos dados pelos discentes aos diversos temas trabalhados em sala de aula, considerando a experiência vivida por eles (Cavalcanti, 2006, p. 33).

\section{Considerações finais}

O desafio na formação de um profissional de Geografia, crítico e cidadão, na modalidade semipresencial, está posto, uma vez que essa modalidade democratiza o acesso de um contingente maior ao ensino superior, no caso de um consórcio de universidades públicas. Tais democratização e oportunidade de acesso são demonstradas por meio das origens dos alunos matriculados no curso de Geografia.

A preocupação quanto à formação desses profissionais nos levou à proposição de oito disciplinas de Teoria e Prática em Geografia, que consistem em um conjunto de abordagens que visam proporcionar ao educando reflexões e práticas que o tornem um profissional capaz de formar alunos com um viés crítico de proporcionar àqueles do ensino básico uma abordagem cidadã da ciência geográfica. Além disso, espera-se que, ao mesmo tempo que tenha sólida formação científica, tenha também condições de efetuar uma transposição desses conteúdos de forma a auxiliar os discentes a entenderem o espaço e a sociedade em que vivem.

Dessa forma, conjugando os aportes conceituais de Piaget e Vygotsky com a nossa realidade, temos a clareza, por um lado, de que a heterogeneidade é imprescindível para as interações sociais, porque imprime a possibilidade de trocas de repertório, de confrontos e de ajuda mútua, fatores fundamentais para a ampliação das capacidades individuais.

Quando concordamos que as ferramentas ou recursos necessários e propulsores do desenvolvimento dos sujeitos e, portanto, garantidores de mudanças são fornecidas pela cultura, a condição dos tutores de tomarem a experiência de vida dos alunos como ponto de partida em suas práticas revela a possibilidade de concretude de uma prática docente inclusiva, sendo inquestionável a contribuição de Vygotsky na viabilização de uma maior e melhor inserção dos alunos de EaD.

Tendo em vista a pluralidade de alunos (licenciandos) que transitam nos diferentes polos e no ambiente da plataforma, entendemos que nossas prá- 
ticas deverão ter como ponto de partida as suas experiências, levando em conta seus ritmos, comportamentos, experiências, trajetórias pessoais - uma prática que procura embutir uma outra visão de aluno (ativo e interativo) e de mundo (complexo, em constantes transformações), melhor adequada ao contexto de EaD.

Todas essas considerações apontam para um espaço que propicia a oportunidade de reconstrução do vivenciado e aprendido, a fim de que o futuro educador não tome os conhecimentos como rituais, cópias com imitações mecânicas de modelos fornecidos.

À equipe de formação, aos professores e tutores formadores cabe, enquanto mediadores do processo ensino-aprendizagem, a função de ampliadores de repertórios dos futuros educadores - os conhecimentos internalizados serão orientados e reorientados de forma a tornar o comportamento e a ação profissional desses futuros educadores mais dinâmicos e criativos.

Não temos dúvida de que é nesse espaço de superação de uma concepção tradicional de aluno e da insurgência teórica - protagonizada por Vygotsky - que conseguiremos dar conta de uma educação verdadeiramente inclusiva e de um licenciando futuro educador e agente de educação social.

Destarte, busca-se a valorização ampliada dos futuros profissionais de Geografia para que cumpram suas funções sociais e atenuem na mediação da construção do conhecimento, sobretudo na atualidade marcada fortemente pela globalização, em que se amplia uma homogeneização do espaço e, contraditoriamente, se ampliam as desigualdades sociais.

A formação de profissionais de Geografia na modalidade semipresencial tem o cuidado de preservar o papel do tutor educador, que é o centro do processo, e, assim, acompanhamos e observamos a atuação dos professores, orientando sua prática pedagógica em princípios que privilegiem o contexto de experiência dos alunos/licenciandos, cujo enfoque sociocultural é contemplado nas situações de aprendizagem e cujas trocas entre os diversos ambientes são levadas em consideração, assim como a multiescalaridade presente no cotidiano, no qual o local e global estão intimamente relacionados. As atividades realizadas nas oito disciplinas de Teoria e Prática em Geografia possibilitam a formação desse profissional em consonância com a atualidade em que vivemos. 


\section{Referências}

ALMEIDA, G. P. Transposição didática: por onde começar? 2 ed. São Paulo: Cortez, 2011.

CALLAI, Helena Copetti (org.). O ensino em estudos sociais. Ijuí: Edunijuí, 1991.

e ANDREIS, A. “Com o mundo nas mãos: a geografia na educação básica”. Revista Geográfica de Valparaiso, n. 47, pp. 3-12, Valparaíso, 2013.

CAVALCANTI, L. S. (org.). Formação de professores: concepções e práticas em geografia. Goiânia: Vieira, 2006.

CHEVALLARD, Y. La transposición didáctica: del saber sabio al saber enseñado. Buenos Aires: Aique, 1991.

CHAUI, M. A vida e o ofício dos professores: formação contínua, autobiografia e pesquisa em colaboração. São Paulo: Escrituras, 2002.

COSTELLA, R. Z. e SCHÄFFER, N. O. A geografia em projetos curriculares: ler o lugar e compreender o mundo. 1 ed. Erechim: Edelbra, 2012, v. 1.

ENDERLE, C. Psicologia do desenvolvimento: o processo evolutivo da criança. 2 ed. Porto Alegre: Artes Médicas, 1987.

GOUVÊA, G e OLIVEIRA, C. I. Educação a distância na formação de professores: viabilidades, potencialidades, limites. Rio de Janeiro: Vieira \& Lent, 2006.

KOZEL TEIXEIRA, S. "Geografia, representação e ensino: um olhar sobre a dimensão conceitual”. In Anais do I Colóquio Nacional do Núcleo de Estudos em Espaço e Representação. Curitiba: Editora da UFPR, 2006, v. 1, pp. 45-58.

LINHARES, C. e LEAL, M. C. (orgs.). Formação de professores: uma critica à razão e à política hegemônicas. Rio de Janeiro. DP\&A, 2002.

LUDKE, M. (coord.). O professor e a pesquisa. Campinas: Papirus, 2001.

MARAFON, G. J. "O trabalho de campo como um instrumento de trabalho para o investigador em geografia agrária”. In DE DAVID, C. e WIZNIEWSKY, C. (orgs.). Agricultura \& transformações socioespaciais. 1 ed. Santa Maria: Evangraf/Jade Editora, 2015, v. 1, pp. 26-46. 
MATTAR, J. Guia de educação a distância. São Paulo: Cengage Learning, 2014.

MELLO, Guiomar Namo. Cidadania e competitividade. São Paulo: Cortez, 1998.

MELLO, M. C. O. e ANGELONI, R. Z. "O lúdico e o dialógico no ensino de Geografia: uma proposta para a prática pedagógica”. Boletim Campineiro de Geografia, v. 4, pp. 487-97, Campinas, 2014.

OLIVEIRA, E. S. G. e COSTA, M. A. "Avaliação dos cursos de licenciatura da UERJ: do espelho ao buraco da fechadura”. In Formação de professores na UERJ: memória, realidade atual e desafios futuros. Rio de Janeiro: Quartet, 2001.

OLIVEIRA, M. K. "Vygotsky e o processo de formação de conceitos”. In Y. de La Taille, M. Oliveira e H. Dantas (eds.). Piaget, Vygotsky, Wallon: teorias psicogenéticas em discussão, pp. 23-34. São Paulo: Summus. 1992.

PERRENOUD, P. Práticas pedagógicas, profissão docente e formação: perspectivas sociológicas. Lisboa: Dom Quixote, 1993.

PIAGET, J. A psicologia da criança. Rio de Janeiro: Bertrand Brasil, 1998 . MAGNE, B. C. Construir: as competências desde a escola. Porto Alegre: Artmed, 1999.

PONTUSCHKA, N. N. et al. Para ensinar e aprender geografia. São Paulo: Cortez, 2009.

RAMOZZI-CHIAROTTINO, Z. Psicologia e epistemologia genética de Jean Piaget. São Paulo: EPU, 1992.

REGO, N. et al. (orgs.). Geografia: práticas pedagógicas para o ensino médio. 3 ed. Porto Alegre: Grupo A, 2017, v. 1.

ROSA, D. E. G. "Formação de professores: concepções e práticas”. In: CAVALCANTI, L. de S. (org.). Formação de professores: concepções e práticas em Geografia. Goiânia: Vieira, 2006.

SANTOS, M. Técnica, espaço, tempo. 3. ed. São Paulo: Hucitec, 1997

SCHÖN, D. A. Educando o profissional reflexivo: um novo design para o ensino e a aprendizagem. Porto Alegre: Artmed, 1998.

TARDIF, M. Saberes docentes e formação profissional. Petrópolis: Vozes, 2002. 
TEÓFILO, V. M. S. Verdade e inclusão: perspectivas na formação dos novos professores (tese). UERJ, 2007.

e FILHO, D. S. Pensando sobre o lugar da avaliação na educação por competências. Rio de Janeiro: Centro de Estudos de Pessoal e Forte Duque de Caxias, 2013, pp. 183-99. (Coletânea HUMANIS).

VALENTE, J. A. e MORAN, J. M. Educação a distância. São Paulo: Summus, 2011.

VYGOTSKY, L. S. Pensamento e linguagem. São Paulo: Martins Fontes, 1989.

. A formação social da mente. São Paulo: Martins Fontes, 1991.

. "Alguns equívocos na interpretação de seu pensamento". Cadernos de Pesquisa, n. 81, pp. 67-9, mai. 1992.

. Psicologia concreta do homem. Manuscrito inédito de Vygotsky. Universidade de Moscou, Vestn. Mosk. Un-ta Ser. 14, Psikhologiya, n. 1, pp. 51-64, 1986. 


\title{
Projeto Parceladas e formação de professores na UNEMAT
}

\author{
Maria Auxiliadora de Azevedo Coutinho e Castro \\ José Amilcar Bertholini de Castro
}

O presente artigo objetiva apresentar, de forma sumária, uma importante experiência formativa de professores, protagonizada pela Universidade Estadual do Mato Grosso (UNEMAT) e iniciada no ano de 1992, com o propósito de qualificar professores leigos em exercício, além de formar professores para atuarem na educação básica do Mato Grosso.

Destacamos que, na década de 1980, o estado do Mato Grosso se notabiliza pelo acentuado crescimento populacional decorrente de denominado processo de reocupação daquela região, com a constituição de cidades e de um contingente populacional expressivo, que não foi acompanhado de uma infraestrutura básica como saneamento, energia elétrica, hospitais, escolas e, obviamente, docentes com formação para lecionar, de sorte que as comunidades estabelecidas nessa região passaram a organizar escolas. Pessoas que tinham o mínimo de escolarização eram convocadas a assumir as aulas, sendo denominados de "professores leigos", fenômeno bastante comum nas regiões mais distantes dos centros urbanos.

Dados disponibilizados no site do INEP informam que, entre as décadas de 1980 e 1990, foram firmados convênios para formação de professores entre os estados da Região Norte e Centro-Oeste com diversas universidades do país, como, por exemplo, as Universidades Federais de Pernambuco, do Ceará e de Santa Maria, cabendo informar que tais ações não foram capazes de dar conta da demanda por mão de obra habilitada. Assim, segundo o Censo Escolar (INEP/MEC), na década de 1990, cerca de 37\% das pessoas que exerciam a função docente na região eram leigas. 
Os debates que antecederam à promulgação da Lei de Diretrizes e Bases da Educação, no ano de 1996, propunham a obrigatoriedade de professores habilitados em nível superior ou formados por treinamento em serviço, o que ficou estabelecido no artigo 87 da referida legislação. Nesse sentido, tornava-se necessária a criação de vários cursos de licenciatura para titular professores que atuavam na condição de leigos, além de formar um contingente de docentes capazes de suprir a demanda daquela região.

Com esse propósito, a UNEMAT estabeleceu, no ano de 1992, o Programa Licenciaturas Parceladas, uma modalidade diferenciada de ensino presencial, oferecido em regime parcelado ou em regime contínuo, com objetivo de atender às demandas de formação de professores em diferentes regiões de Mato Grosso, e já serviu de exemplo para outras universidades brasileiras.

Para avaliar a extensão desse projeto, é necessário anteceder, para efeitos de explanação, às condições objetivas em que foi implantado, fato que, de per $s i$, distingue e agiganta sua importância, fazendo justiça ao excelente retorno já comprovado na formação docente, especificamente, bem como na educação de Mato Grosso de uma maneira geral.

A universidade incubadora que acolhe e mantém o Programa Licenciaturas Parceladas, que proporcionou a primeira experiência, sua posterior maturação e adaptações é a UNEMAT, entidade pública fundada em 15 de dezembro de 1993, por meio da Lei Complementar n. ${ }^{\circ}$ 30, mantida pela Fundação Universidade do Estado de Mato Grosso. Teve seus estatutos aprovados e homologados em 10 de janeiro de 1995, pelo Conselho Estadual de Educação de Mato Grosso, por meio da Resolução n..$^{\circ}$ 001/95-CEE/MT, publicada no Diário Oficial do Estado em 14 de março de 1996 (Zattar, 2008).

No entanto, apenas em 10 de agosto de 1999, a Universidade foi credenciada pelo Conselho Estadual de Educação. A partir de então, passou a gozar de autonomia didática, científica e pedagógica.

O Programa Parceladas da UNEMAT, criado desde 1992, careceria de convalidação legal como modalidade diferenciada de ensino, pois nasceu sob tutoria e abrigo institucional da Fundação Centro de Ensino Superior de Cáceres (FCESC), que viria, por meio da Lei Complementar no 14 , de 16 de janeiro de 1992, transformar-se em Fundação Centro de Ensino Superior de Cáceres (FCESC), posteriormente denominada de Fundação de Ensino Superior de Mato Grosso (FESMAT), cuja estrutura organizacional foi implantada a partir de maio de 1993, mantendo-se como Centro Universitário até o credenciamento como universidade UNEMAT, que ocorreu em 1999. 
Trazendo desde o nascedouro a promessa de interiorizar o ensino superior, a UNEMAT enfrenta externamente barreiras impostas pela distância dos grandes centros de excelência acadêmica e, internamente, tem sido desafiada diuturnamente pela gigantesca extensão territorial do estado, terceiro maior do país, que possui uma área de $903.329 \mathrm{~km}^{2}$, com a menor densidade demográfica do Centro-Oeste.

A população estimada de Mato Grosso é de 3.305 .531 habitantes. Segundo dados divulgados pelo IBGE (Instituto Brasileiro de Geografia e Estatística), essas pessoas estão desigualmente distribuídas em 141 municípios, com desertos demográficos ao norte; municípios que não chegam sequer a reunir 3.000 habitantes na região leste, possuindo também áreas urbanas populosas, como Cuiabá e Várzea Grande.

$\mathrm{Na}$ intenção de ofertar educação superior pública gratuita e de qualidade, a estrutura administrativa da UNEMAT adaptou-se no formato multicampi, fazendo-se presente em diferentes cidades-polos, como: Sinop, Alta Floresta, Nova Xavantina, Alto Araguaia, Pontes e Lacerda, Luciara, Colíder, Barra do Bugres, Tangará da Serra, Diamantino e Nova Mutum, tendo Cáceres como sede administrativa.

Figura 1: Campi/Núcleo Pedagógico e Polos, em 2011

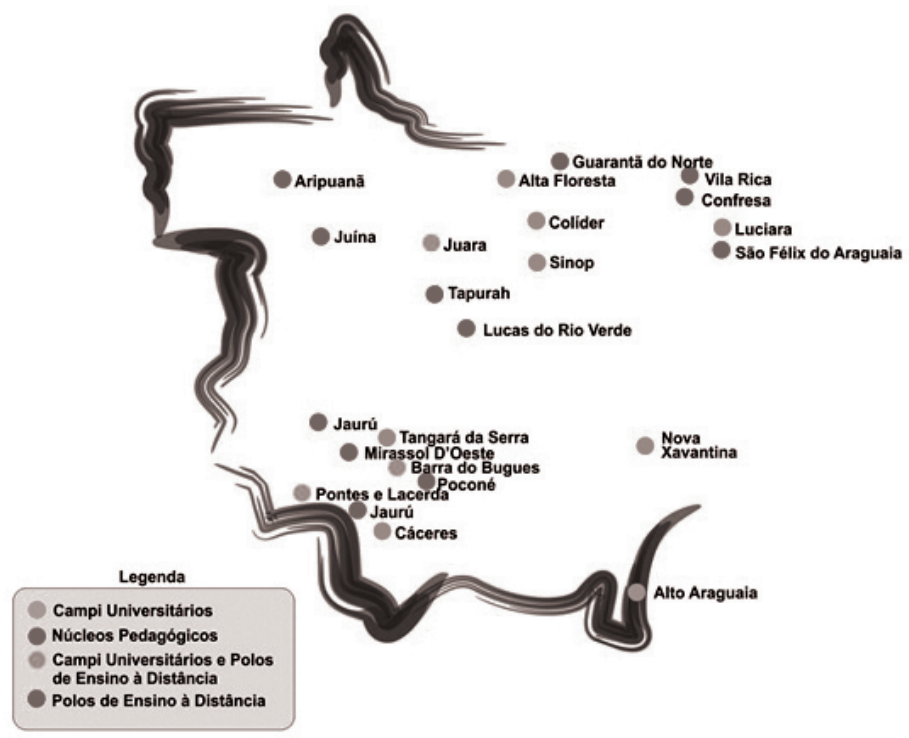

Fonte: site da UNEMAT - Projeto Parceladas 
A estrutura atual permite, por meio de atendimento presencial, presencial parcelado e na modalidade de educação a distância, que a UNEMAT se faça presente em 108 dos 141 municípios mato-grossenses, com 13 campi e 16 núcleos pedagógicos.

Cerca de 15.000 acadêmicos são atendidos em 82 cursos regulares e modalidades diferenciadas oferecidas em todo o estado, com inúmeras especializações, 11 mestrados institucionais, quatro mestrados profissionais, um mestrado interinstitucional, quatro doutorados institucionais, dois doutorados interinstitucionais e três doutorados acadêmicos em rede.

A UNEMAT, por meio de projetos e programas estruturados de acordo com as peculiaridades de cada região do estado e seu respectivo público-alvo, desenvolve ações pioneiras no âmbito do Ensino Superior, destacando-se o Projeto Terceiro Grau Indígena, Educação Aberta e a Distância e o Programa de Licenciaturas, Bacharelados Tecnólogo Parceladas, que oferta cursos para a formação de professores pelo interior do Mato Grosso. ${ }^{1}$

Abraçando a mesma filosofia implantada pela universidade, e na esteira da sua expansão, o Programa de Licenciaturas Parceladas tem como meta viabilizar o acesso ao ensino superior público às mais longínquas regiões do estado. Nos seus primórdios, deu exclusividade à formação de professores; posteriormente, passou a ofertar bacharelados e cursos tecnólogos.

O programa teve como polo inicial o recém-criado campus universitário do Médio Araguaia, em Luciara, cidade situada a aproximadamente $1.300 \mathrm{~km}$ da sede da universidade no município de Cáceres. O Programa de Licenciaturas Parceladas da UNEMAT inicia suas atividades com um perfil fortemente voltado para suprir a demanda específica de uma região na maior parte rural, com baixíssima densidade demográfica, num município que se estende por $4.243,1 \mathrm{~km}^{2}$ e contava com 2.229 habitantes no último censo; portanto, uma densidade demográfica de 0,5 habitantes por $\mathrm{km}$ quadrado.

É importante ressaltar que, em 1992, a grande maioria dos professores daquela região, atuantes na educação rural e em áreas indígenas, era composta de "professores leigos", não havendo profissionais em número suficiente para suprir a demanda educacional localizada, nem acesso próximo que favorecesse a formação profissional na forma tradicional de docentes, visto que as

${ }^{1}$ Diretoria das Licenciaturas e Bacharelados parcelados UNEMAT 
universidades mais próximas se localizam no estado de Goiás e em Cuiabá, decorrendo dessas variáveis a escolha da região.

O Programa consolida-se desde então, pautando suas atividades, intervenções e projetos à luz das seguintes diretrizes:

a) Proporcionar aos egressos do Ensino médio, no interior do estado de Mato Grosso (regióes geo-educacionais), o acesso ao Ensino Superior;

b) Construir o conhecimento sob uma perspectiva sócio histórica, solidária, de ação conjunta, integrando teoria e prática, concepção e execução; c) Conceber a pesquisa como eixo central dos cursos oferecidos, em torno do qual se articulam as várias disciplinas de uma matriz curricular básica, mas não inflexível, assim como todas as atividades acadêmicas.

d) Promover uma formação profissional calcada em uma relação interativa e reflexiva do seu fazer pedagógico, da aquisição, da elaboração e re-elaboração do conhecimento e a manifestação desse saber por meio da produção científica;

e) Fortalecer o processo interativo Universidade/Sociedade/Escolas de Ensino Fundamental e Médio, coordenando ações integradas que favoreçam o crescimento dos sujeitos envolvidos em cada uma daquelas categorias e o aproveitamento racional dos recursos (Projeto Licenciaturas Parceladas, 1992).

A partir de 2010, o Programa Parceladas, em parceria com o governo federal, passou também a oferecer cursos do Programa Emergencial de Formação de Professores da Educação Básica em exercício (Parfor), viabilizando, prioritariamente, as denominadas segundas licenciaturas.

Em 2012, o programa implantou núcleos em seis cidades do interior do estado, as quais foram contempladas com 15 cursos.

Depois de consolidado e fortalecido, principalmente pela excelência dos resultados, é expandido para outras regiões. Podemos afirmar essa particularidade porque estudos realizados por Moreira (2016) contribuem para tal conclusão, inclusive apontando a motivação inicial da implantação, que seria 
dar continuidade à formação de professores leigos da zona rural que fora iniciada pelo Projeto Inajá. ${ }^{2} \mathrm{~A}$ autora nos apresenta a seguinte assertiva:

Segundo o relatório final do Projeto Inajá, o curso aconteceu com um perfil diferenciado, pois buscava trabalhar com os cursistas a partir de suas realidades; foi moldado de modo a atender pessoas da zona rural, urbana e indígenas dessas cidades e contou com mais de 100 alunos (pessoas que atuavam como professores leigos). $\mathrm{O}$ projeto foi oferecido durante as férias desses professores, para que o ano letivo não fosse prejudicado, bem como, para que as práticas desenvolvidas e estudadas durante as férias pudessem ser utilizadas em suas salas de aula no decorrer do ano. Recebeu contribuição da Unicamp, que cedeu professores para irem até a região ajudarem no Projeto, sendo que cada etapa acontecia em um município distinto. Além da Unicamp, teve o apoio das prefeituras, da SEDUC e da Igreja Católica que sempre disponibilizava espaço físico e até auxiliava financeiramente quando os cursistas não tinham como se locomover até o polo em que aconteceria a etapa. Em cada município ficava um monitor que, geralmente, era o secretário de educação ou um professor que já tivesse, pelo menos, cursado o ensino médio (Moreira, 2016, p. 58).

Quando da conclusão do Projeto Inajá, os egressos estavam habilitados com o magistério, passando a demandar uma formação superior, sendo essa demanda encaminhada à UNEMAT, de sorte a constituir uma importante experiência de formação de professores em exercício, constituindo-se como um projeto de formação em serviço e continuada.

O currículo das licenciaturas que foram ofertadas inicialmente era dividido em dois blocos. Iniciava com a Formação Básica, com duração de um ano e meio, e, na sequência, era ofertada a Formação Específica, com duração de dois anos e meio, otimizando, assim, a formação docente.

\footnotetext{
${ }^{2}$ Projeto Inajá I - Projeto que capacitou 124 professores em serviço na região do Araguaia, na década de 1980. Muitos eram professores da zona rural, urbana e também da aldeia Tapirapé. Contou com 17 monitores nos municípios envolvidos, e 25 professores fizeram parte do corpo docente, a maioria da UNICAMP, atuando diretamente com os professores leigos nas diferentes áreas de conhecimento, durante as etapas intensivas do curso. Seu principal objetivo foi capacitar e habilitar professores leigos que estivessem atuando em salas de aula, dando prioridade aos da zona rural e aos indígenas.
} 
Os professores em exercício, que não possuíam formação específica em curso superior e já atuavam no magistério, utilizavam as férias escolares, nos meses de janeiro, fevereiro e julho, por um período de quatro anos, para viabilizar sua formação.

A investigação de Moreira salienta que foi relevante para o sucesso do programa o engajamento dos alunos, verificando-se, até hoje, baixíssimas taxas de evasão.

Quando os Cursos de Licenciaturas Plenas Parceladas iniciaram, a UNEMAT era uma universidade nova e carente de recursos, mas contava com a colaboração de diversas instituições, entre elas: UNICAMP, UNESP, USP, UFSCar, UFMT, UFSC, UFRJ e UFRGS.

$\mathrm{Na}$ região em questão, à época estudada, existiam vários conflitos de terras, com brigas políticas, entravando o desenvolvimento dos cursos e, consequentemente a formação de professores (Moreira, 2016, p. 60).

Gentil (2005) enfatiza que o envolvimento da Igreja Católica na região em temáticas educacionais foi um marco importante, principalmente pela presença do Bispo Dom Pedro Casaldáliga, que chegou à região na década de 1970 e ainda hoje está no município de São Félix do Araguaia. Nos documentos da prelazia, bem como nos relatos dos discentes e docentes que participaram do projeto, encontramos referência ao fato de que a grande maioria dos alunos graduandos utilizou a estrutura da prelazia como alojamento, e a Igreja Católica ter subsidiado muitos cursistas do Inajá.

Acerca do impacto dessa formação de professores na região, destacamos o aumento dos índices de desenvolvimento humano, prioritariamente no quesito "Educação", registrado na região Araguaia depois da implantação do projeto, ressaltando que aquela área, bem como a cidade de Luciara, continua apresentando contra índices preocupantes de desenvolvimento econômico, de saúde, etc.

O Atlas do Desenvolvimento Humano no Brasil, em 2013, elaborado pelo Programa das Nações Unidas para o Desenvolvimento (PNUD), em parceria com o Instituto de Pesquisa Econômica e Aplicada (IPEA) e a Fundação João Pinheiro, avaliou o Índice de Desenvolvimento Humano Municipal (IDHM) dos 5.565 municípios brasileiros, considerando 180 indicadores socioeconômicos dos censos do IBGE de 1991, 2000 e 2010, incluindo demografia, saúde, trabalho, renda, educação, habitação e vulnerabilidade social. 
A maior parte dos municípios da região Araguaia tem índices de desenvolvimento humano abaixo da média nacional. Porém, numa análise temporal, de 1991 até 2010, a região seguiu a tendência nacional de elevar consideravelmente o IDH dos municípios. Apesar de o componente de longevidade ter o índice mais alto nos municípios da região, o incremento do índice de educação foi maior durante o período.

Luciara teve um movimento ascendente e contínuo dos índices de desenvolvimento humano registrado desde 1991, quando foi contabilizado o índice de 0,352. Em 2000, elevou-se para 0,534 e, em 2010, para 0,676 (PNUD).

Devemos considerar que o maior desafio vivenciado pelos profissionais envolvidos nesse programa de formação docente foi e continua sendo a dificuldade de acesso. Além das enormes distâncias entre a sede da universidade e os núcleos pedagógicos, muitas estradas não possuem pavimentação asfáltica, e, em algumas localidades, o melhor acesso ainda é por via fluvial.

Tal dificuldade não tem de ser vencida apenas pelos professores e instrutores, tendo em vista que os alunos (professores em formação) também são obrigados a se deslocar de suas regiões, ficando alojados nas pequenas cidades que se transformam em polos educacionais durante as etapas de formação.

Apenas com o intuito de ampliar o debate, buscamos elementos que dão a dimensão dos deslocamentos exigidos para execução de uma etapa do programa na região do Araguaia; como exemplo, a equipe de professores e apoio que se desloca de Cáceres para Luciara, distância de $1.396 \mathrm{~km}$, isto é, mais de dez horas de viagem.

No entanto, os alunos do programa que residem em Água Boa deslocam-se 354,40 km; os que lecionam em Santa Terezinha, 433,00 km; em Ribeirão Cascalheira, 227,00 km; em Porto Alegre do Norte, 240,00 km, e, para deslocar-se de Cana Brava do Norte até Luciara, é preciso viajar 243,00 km. Ainda assim, o programa obtém um índice de evasão ínfimo, quase zero, desde seu início até hoje.

Em 2013, com outras parcerias entre a Universidade do Estado de Mato Grosso, a Secretaria de Ciências e Tecnologia, Secretaria de Educação e a Prefeitura do Município de Matupá, foram abertas mais 150 vagas em três cursos de licenciatura de três diferentes áreas de conhecimento, totalizando 780 vagas abertas. 
Figura 2: Formatura das primeiras turmas desde 1997

\begin{tabular}{|c|c|c|}
\hline $1997 / 1$ & 33 & Lic. Letras - Luciara \\
\hline $1997 / 1$ & 36 & Lic. Matemática - Luciara \\
\hline $1997 / 1$ & 31 & Lic. Pedagogia - Luciara \\
\hline $1999 / 1$ & 45 & Lic. Letras - Barra do Bugres \\
\hline $1999 / 1$ & 38 & Lic. Matemática - Barra do Bugres \\
\hline $1999 / 1$ & 39 & Lic. Ciências Biológicas - Barra do Bugres \\
\hline $1999 / 1$ & 29 & Lic. Matemática - Colíder \\
\hline $1999 / 1$ & 33 & Lic. Ciências Biológicas - Colíder \\
\hline $1999 / 1$ & 36 & Lic. Letras - Colíder \\
\hline $2001 / 2$ & 43 & Lic. Matemática - Alta Floresta \\
\hline $2001 / 2$ & 48 & Lic. Letras - Alta Floresta \\
\hline $2001 / 2$ & 44 & Lic. Pedagogia - Alta Floresta \\
\hline $2001 / 2$ & 46 & Lic. Geografia - Luciara \\
\hline $2001 / 2$ & 54 & Lic. História - Luciara \\
\hline $2002 / 1$ & 44 & Lic. Ciências Biológicas - Luciara \\
\hline $2002 / 1$ & 46 & Lic. Letras - Rosário Oeste/Barra do Bugres \\
\hline $2002 / 1$ & 39 & Lic. Matemática - Rosário Oeste/Barra do Bugres \\
\hline $2002 / 1$ & 55 & Lic. Ciências Biológicas - Barra do Bugres \\
\hline $2004 / 2$ & 23 & Lic. Matemática - Araputanga/Pontes e Lacerda \\
\hline $2004 / 2$ & 44 & Lic. Ciências Biológicas - Araputanga/Pontes e Lacerda \\
\hline $2004 / 2$ & 47 & Lic. Pedagogia - Araputanga/Pontes e Lacerda \\
\hline $2004 / 2$ & 45 & Lic. Letras - Comodoro/Pontes e Lacerda \\
\hline $2004 / 2$ & 43 & Lic. Matemática - Comodoro/Pontes e Lacerda \\
\hline $2004 / 2$ & 37 & Lic. Pedagogia - Comodoro/Pontes e Lacerda \\
\hline $2007 / 1$ & 57 & Lic. Ciências Biológicas - Luciara \\
\hline $2007 / 1$ & 55 & Lic. Geografia - Luciara \\
\hline $2007 / 1$ & 55 & Lic. Pedagogia - Vila Rica \\
\hline $2007 / 1$ & 54 & Lic. Matemática - Vila Rica \\
\hline $2007 / 1$ & 57 & Lic. História - Confresa \\
\hline $2007 / 1$ & 59 & Lic. Letras - Confresa \\
\hline $2008 / 1$ & 18 & Lic. Matemática - Nobres \\
\hline $2009 / 1$ & 42 & Lic. Geografia - Jaciara \\
\hline $2009 / 1$ & 31 & Lic. História - Jaciara \\
\hline
\end{tabular}




\begin{tabular}{|c|c|l|}
\hline $2009 / 2$ & 36 & Lic. Ciências Biológicas - Poconé \\
\hline $2010 / 2$ & 41 & Lic. Geografia - Poconé/Cáceres \\
\hline $2011 / 1$ & 35 & Lic. Matemática - Vila Rica \\
\hline $2011 / 1$ & 39 & Lic. Letras - Confresa \\
\hline $2011 / 2$ & 54 & Lic. Química - Luciara \\
\hline $2014 / 1$ & 36 & Lic. Letras/Espanhol (Parfor) - Luciara \\
\hline $2014 / 1$ & 20 & Lic. Ciências Biológicas (Parfor) - Luciara \\
\hline Total & $\begin{array}{c}1.667 \\
\text { professo- } \\
\text { res }\end{array}$ & 13 núcleos pedagógicos \\
\hline 41 cursos & \multicolumn{2}{|c|}{} \\
\hline
\end{tabular}

Fonte: UNEMAT.

Em 2014/1, o Programa Parceladas planejou atender a uma nova demanda: pela primeira vez, cursos de graduação nas modalidades de bacharelado e tecnológo, disponibilizando 500 (quinhentas) vagas, distribuídas em 10 (dez) cursos de 5 (cinco) diferentes áreas de conhecimento, em 7 (sete) cidades do interior do estado de Mato Grosso. Ressalta-se que esses cursos visam à formação e à qualificação de 200 (duzentos) bacharéis, 100 (cem) tecnólogos e 200 (duzentos) docentes da Educação Básica.

Figura 3: Graduação em andamento com término previsto para 2016 e 2017/2

\begin{tabular}{|l|c|}
\hline Curso & Campus universitário \\
\hline $\begin{array}{l}\text { Licenciatura em Ciências Sociais - Antropologia, } \\
\text { Ciência Política e Sociologia }\end{array}$ & Confresa \\
\hline Licenciatura em Letras/Espanhol & Confresa \\
\hline Licenciatura em Letras/Inglês & Confresa \\
\hline Licenciatura em Computação & Vila Rica \\
\hline Licenciatura em Educação Física & Vila Rica \\
\hline Licenciatura em Química & \\
\hline Licenciatura em Pedagogia do Campo & Luciara \\
\hline Licenciatura em Letras/Espanhol & Luciara \\
\hline Licenciatura em Ciências Biológicas & Luciara \\
\hline
\end{tabular}




\begin{tabular}{|l|c|}
\hline Licenciatura em Geografia & Tangará da Serra \\
\hline Licenciatura em História & Alta Floresta \\
\hline Licenciatura em Pedagogia do Campo & Sinop \\
\hline Licenciatura em História & Matupá \\
\hline Licenciatura em Matemática & Matupá \\
\hline Licenciatura em Química & Matupá \\
\hline
\end{tabular}

Fonte: elaborado pelos autores com base nos dados disponibilizados pela UNEMAT.

Figura 4: Cursos com ofertas iniciadas em 2014/1 e término previsto para 2017/2

\begin{tabular}{|l|c|}
\hline Curso & Núcleo pedagógico \\
\hline Bacharelado em Ciências Contábeis & Campos de Julho \\
\hline Licenciatura em Pedagogia do Campo & Caramujo \\
\hline Bacharelado em Administração & Mirassol D’Oeste \\
\hline Bacharelado em Ciências Contábeis & Mirassol D’Oeste \\
\hline Bacharelado em Ciências Contábeis & Nova Lacerda \\
\hline Licenciatura em Pedagogia & Rio Branco \\
\hline Licenciatura em Matemática & Rio Branco \\
\hline Licenciatura em Pedagogia & São José dos Quatro Marcos \\
\hline Tecnólogo em Agroecologia & Sáo José dos Quatro Marcos \\
\hline Tecnólogo em Agroecologia & Vila Bela da Santíssima Trindade \\
\hline Bacharelado em Ciências Contábeis & Itiquira \\
\hline Licenciatura em Pedagogia & Cursos de férias/Itiquira \\
\hline Licenciatura em Pedagogia & Alto Araguaia \\
\hline Bacharelado em Direito & Alto Araguaia \\
\hline
\end{tabular}

Fonte: elaborado pelos autores com base nos dados disponibilizados pela UNEMAT.

\section{Considerações finais}

O presente artigo apresenta uma experiência de formação inicial de professores leigos em um contexto de reduzida utilização das denominadas Tecnologias da Informação e Comunicação (TICs) em uma região marcada 
pela crescente demanda de docentes qualificados, decorrente do crescimento populacional do estado do Mato Grosso em meados da década de 1980.

Naquele contexto, a criação da UNEMAT, enquanto uma instituição intencionalmente interiorizada, associada a um conjunto de parcerias com universidades de outras regiões do Brasil, viabilizou a formação de um contingente expressivo de docentes, com formação em diferentes áreas, que já atuavam sem a devida formação, contrariando os dispositivos legais vigentes.

Os dados sistematizados pela UNEMT informam que o impacto nas redes municipal e estadual nos locais onde a oferta de licenciaturas parceladas ocorreu foi expressivo, de sorte a potencializar uma importante articulação entre práticas docentes leigas e saberes científicos e pedagógicos capazes de transformar a realidade onde esses docentes vivem.

Ainda que, no contexto atual, a possibilidade de formação inicial tenha sido ampliada significativamente, em razão da expansão da oferta de cursos na modalidade EaD, a oferta de licenciaturas parceladas ainda se configura como um importante programa da UNEMAT, que, devido à demanda, tem se reorientado para bacharelados e tecnólogos, replicando experiências bem-sucedidas de formação de professores.

\section{Referências}

ALBUQUERQUE, J. G. de et al. Projeto Inajá. Cuiabá: Secretaria de Educação e Cultura, 1991.

. "Uma proposta de integração entre ensino e pesquisa". Revista ADUSP, São Paulo, jun. 1997.

ATLAS BRASIL 2013. Atlas do Desenvolvimento Humano no Brasil 2013. Disponível em: http://www.atlasbrasil.org.br/2013/pt/ranking. Acesso em: 14 dez. 2017.

CAMARGO, D. M. P. Mundos entrecruzados: formação de professores leigos. Campinas: Alínea, 1997.

GENTIL, H. S. Formação docente: no balanço da rede entre politicas públicas e movimentos sociais (dissertação). FACED, 2002. 
MOREIRA, W. B. "Minha terra tem palmeiras onde canta o sabiá...": sobre o Projeto Inajá e a formação de professores no médio Araguaia (dissertação). UNESP, 2016.

ROLKOUSKI, E. Vida de professor de matemática: (im)possibilidades de leitura (tese). UNESP, 2006.

SOARES, I. M. A formação do professor em exercício: uma análise da licenciatura plena parcelada em matemática da Unemat-MT (dissertação). Universidade São Francisco, 2005.

SOUSA, J. A construção da identidade profissional do professor de matemática no Projeto Licenciaturas Parceladas da Unemat-MT (tese). PUC-SP, 2009.

STRENTZKE, I. Inajá homem-natureza e geração tucum: uma análise da proposta pedagógica de 1987 a 2000 (dissertação). UFMT, 2011.

UNEMAT. Disponível em: www.novoportal.unemat.br. Acesso em: 28 out. 2017.

ZATTAR, N. B. da S. Do IESC à UNEMAT: uma história plural 19782008. Cáceres: Editora UNEMAT, 2008. 
PARTE II

ForMAÇ̃̃̃O DOS EDUCADORES DO CAMPO 


\title{
Trajetórias pelo PIBID Interdisciplinar Educação no Campo
}

\author{
Atuação em uma escola no campo
}

Ivanio Folmer

Ane Carine Meurer

\section{Introdução}

O intuito principal do Programa Institucional de Bolsas de Iniciação à Docência (PIBID) é proporcionar aos licenciandos uma relação direta com as escolas. Assim, aumentam as condições de, durante a formação inicial, articular teoria e prática nas realidades educacionais das escolas de educação básica, em especial no subprojeto interdisciplinar "Educação do Campo", que atende a escolas públicas de Santa Maria localizadas no campo. No referido subprojeto, planejam-se diversas atividades com o coordenador, supervisor e bolsistas de iniciação à docência. A proposta é articulá-las, tendo como aspiração de futuro o "projeto da educação do campo" e como ponto de partida as necessidades da comunidade atendida.

O objetivo deste capítulo é relatar a experiência do educando de Geografia no PIBID, o qual esteve inserido na Escola de Ensino Fundamental Arroio Grande, no município de Santa Maria, no ano de 2014, onde foram desenvolvidas atividades didáticas, regência e trabalhos com a comunidade escolar de modo geral, sob orientação da coordenadora-geral do subprojeto. A existência de um projeto interdisciplinar no espaço rural surge na tentativa de amenizar as condições da realidade, e, dessa forma, as problemáticas do campo se apresentam quando se observa de que maneira ocorre a educação do campo e como ela se manifesta dentro de uma comunidade rural. 
Muitas vezes, a escola está preocupada em inserir o indivíduo em uma cultura dita evoluída, desprezando situações e momentos que são de grande importância para o sujeito do campo, como a sua realidade e os saberes historicamente acumulados. Assim, quer inovar, inserir, e não reconstruir a partir do que os sujeitos já são, pois eles já têm. É essencial auxiliar a valorização do campo, trazendo para a sala de aula o seu cotidiano, com ligações diretas de apreciação da terra e compreensão dos fenômenos ali existentes, reconhecendo atividades que são passadas de geração para geração.

A ideia de preservação deve estar aliada a investidas da escola, trabalhando não só com os educandos, mas também com as suas famílias. Assim, contribui-se para a formação desses sujeitos, valorizando-se sua história, conhecendo-se como se desenvolvem, as condições onde vivem, dando-se condições para que tais indivíduos passem a fazer interpretações reais do espaçotempo em que habitam, sem entrar no estigma que a sociedade já criou sobre o campo, colocando-os como atrasados. Esse é um dos motivos que fazem com que os jovens não queiram fazer parte dessa realidade.

\section{Os primeiros passos do pibidiano}

A primeira etapa para o educando ingressante no subprojeto Educação do Campo é, sem dúvidas, um dos passos que serão decisivos para sua permanência ou não. Os educandos, quando ingressam nesse projeto, são convidados a participar de uma investigação socioantropológica em torno das vivências dos alunos, que fazem parte das escolas que serão atendidas por tal grupo, acompanhado pela coordenadora do projeto e por uma supervisora, professora da escola. Além dessa visita realizada nas residências dos alunos e na comunidade escolar do campo, os pibidianos observam a escola, na tentativa de conhecer os alunos, professores e funcionárias(os).

Esse momento inicial serve para conhecer o espaço físico da escola, incluindo números de alunos por sala, materiais didáticos disponíveis e conhecimento sobre o desempen ho, o comportamento, o aproveitamento em sala de aula. Nesse caso, a Geografia, tão rica e fascinante, mas cujos professores no campo, muitas vezes nem se dão conta de que podem explicar sobre Espaço Geográfico e Espaço Social, paisagens naturais e artificiais, lugares onde acontecem as relações, territórios que se criam, se desfazem, se recriam, bem como a apropriação desses territórios, utilizando a realidade onde a escola está inserida, ou seja, a mesma dos educandos. 
Num primeiro momento, nasceram algumas inseguranças que, conforme as reuniões aconteciam, com periodicidade semanal, iam sendo sanadas. $\mathrm{O}$ acompanhamento da orientadora, da supervisora e da equipe no planejamento diminuía a insegurança e aumentava o interesse de proporcionar ao grupo e aos educandos da escola novas atividades, novos planos, novos projetos. Pensa-se que conteúdo e material didático não são os únicos indicadores de qualidade do ensino que é apresentado na escola - onde se ensina (contexto social), se o que se ensina é relevante à interpretação, e por que se prioriza o que se ensina, entre outras questões, devem ser frequentemente abordadas.

Na segunda etapa de atuação dentro da instituição escolar, nós, futuros professores, iniciamos a inserção de atividades, criadas em alguns momentos pelo grupo, em outras situações, aproveitando ideias pré-construídas pela escola e/ ou seguindo sugestões da coordenação, cooperando com o desenvolvimento da própria escola. Nesse tocante, tornamo-nos protagonistas e não apenas observadores das atividades que aconteciam na escola, apoiando-nos nos demais participantes do grupo, dialogando com professoras e supervisão escolar e investigando atentamente o público-alvo, que é formado por educandos.

Ao mesmo tempo em que se assumia o papel ativo em sala de aula, ser chamado de professor tornava-se uma das mais belas conquistas que não estavam nos planos: mas que gerava emoção e fazia com que as vontades se renovassem diante das dificuldades que surgiam. Essas dificuldades acabaram tornando-se insignificantes com o ganho de todos. Uma das mais gratificantes sensações era receber o afeto dos alunos, que interagiam e se conectavam com o coletivo, gerando-se um grande grupo, no qual não se diferenciava por hierarquia, pois os alunos estavam sendo tratados como sujeitos protagonistas de suas histórias, que mereciam ser ouvidas e que, muitas vezes, geravam comoção, fortalecendo os laços.

O terceiro momento é marcado pela perspectiva de criação de projetos, que eram/são vistos como estratégias para o trabalho dos temas geradores que eram levantados, e que eram trazidos pelos educandos a partir de suas próprias vivências. Assim, iniciamos colaborando com os educadores regentes e fomos buscando autonomia para ir além do esperado, caminhando além da investigação dos conteúdos, atendendo à demanda real dos nossos educandos.

O Programa funciona de maneira diferenciada dos estágios curriculares obrigatórios, os quais, na sua maioria, exigem do futuro professor uma metodologia crítica e com conteúdos diversificados em curto espaço de tempo. Desse modo, a sala de aula não se torna um ambiente artificial e inexperiente 
do sistema educacional, que apresenta falhas. Em geral, o relatório final tem o papel de incumbir notas associadas às condições das normas metodológicas utilizadas pelo estagiário em situação avaliativa. Por esse motivo, é visível a função positiva do PIBID e seu posicionamento dinâmico e contemplativo das inúmeras esferas que compõem o grupo escolar, em que o bolsista, situado no ambiente da escola, leva condições relevantes de averiguar e identificar problemáticas e observação da devida forma de compreensão do real contexto da atuação do professor.

Nesse sentido, o PIBID proporciona aos bolsistas uma experiência rica dando embasamento teórico e prático para as experiências que permeiam o contexto escolar. No entanto, cabe ressaltar que nenhuma formação docente se dá pela neutralidade, mas pelos conflitos existentes nos diversos contextos. Desse modo, a participação do PIBID na construção do professor é um ensaio do real, presente neste tempo, em que o educador constrói ferramentas que serão usadas quando atuar na profissão. No PIBID interdisciplinar Educação do Campo, os alunos possuem acesso à construção de conceitos que são trabalhados de maneira coletiva, pois até mesmo nas universidades os futuros professores não aprendem a trabalhar de maneira integrada, mas sim de modo fragmentado, e os cursos não têm conhecimento sobre o outro, não há diálogos entre as áreas, o que possibilita a individualidade delas. Programas com cunho interdisciplinar são muito importantes para a construção de um profissional que pense de maneira integradora. Dessa maneira, os projetos que serão trabalhados por esses professores em escola abrangerão de maneira a estender-se por uma rede maior e possuir uma condição de reaplicabilidade significativa.

\section{PIBID do campo e os conceitos importantes para seu desenvolvimento nas escolas em atuação}

Para o Brasil, que foi colônia de exploração durante mais de 300 anos, o desenvolvimento de um sistema educacional não era/é considerado uma prioridade. As pessoas que desempenhavam maior representatividade nas atividades agrícolas eram os escravos - índios e negros africanos - e também os colonos imigrantes; estes se encontravam em desvantagem ao já sistema capitalista daquele momento, não esperavam por políticas educacionais, pois não se considerava necessário saber ler e escrever para trabalhar com a terra (Silva, 2004). 
Assim, inspirando-nos em Caldart (2009), podemos dizer, sobre a

Educação do campo, que sua natureza e seu destino estão profundamente ligados ao destino do trabalho no campo e, consequentemente, ao destino das lutas sociais dos trabalhadores e da solução dos embates de projetos que constituem a dinâmica atual do campo brasileiro, da sociedade brasileira, do mundo sob a égide do capitalismo em que vivemos. E ainda que 'muitos não queiram', esta realidade exige posição (teórica sim, mas sobretudo prática, política) de todos os que hoje afirmam trabalhar em nome da Educação do campo (Caldart, 2009, p. 3).

Também cabe dizer que a Educação do Campo é uma ferramenta conquistada pelo Movimento dos Trabalhadores Rurais sem Terra, que visava obter uma educação comprometida com os alunos, filhos de militantes e dos demais camponeses.

A Educação do campo inicia sua atuação desde a radicalidade pedagógica deste movimento social e entra no terreno movediço das políticas públicas, da relação com um Estado comprometido com um projeto de sociedade que ela combate, se coerente for com sua materialidade e vínculo de classe de origem. Sim! A Educação do campo tem se centrado na escola e luta para que a concepção de educação que oriente suas práticas se descentre da escola, não fique refém de sua lógica constitutiva, exatamente para poder ir bem além dela enquanto projeto educativo. E uma vez mais, sim! A Educação do campo se coloca em luta pelo acesso dos trabalhadores ao conhecimento produzido na sociedade e ao mesmo tempo problematiza, faz a crítica ao modo de conhecimento dominante e à hierarquização epistemológica própria desta sociedade que deslegitima os protagonistas originários da Educação do campo como produtores de conhecimento e que resiste a construir referências próprias para a solução de problemas de uma outra lógica de produção e de trabalho que não seja a do trabalho produtivo para o capital (Caldart, 2009, p. 3).

Com as palavras de Caldart (2009), podemos entender que o projeto de Educação do Campo, no qual se inserem as escolas do campo, foi pensado para que a escola do campo constituísse um estabelecimento político e social capaz de ajudar na organização social dos sujeitos do campo, assim como auxiliar no 
processo de autonomia dos camponeses. Por esse viés, o PIBID se insere no processo da construção de identidade dos educadores que vão atuar nessas escolas que fazem parte do projeto (convém dizer que o projeto não atende à demanda de todas as escolas do campo estaduais e municipais de Santa Maria). Além de auxiliar no desenvolvimento de saberes em torno desta especificidade, tentávamos estabelecer contato com a comunidade, na busca de sensibilizar e valorizar o espaço onde estão inserindo.

Infelizmente, a comunidade em que a escola está inserida não faz parte de um movimento social, mesmo que existam formas de organização na comunidade, principalmente em torno do sindicato e da igreja; em contrapartida, com o projeto em ação, foi-se percebendo a introdução dos alunos nesses espaços, interessados e interagindo com a comunidade que circunda a escola. O território de que a ela faz parte não se apresenta de forma engessada, pois há várias investidas na comunidade, sobretudo pelo capitalismo. Conforme Fernandes (2012), para pensar o território nesta conjuntura, deve-se considerar a conflitualidade existente entre o campesinato e o agronegócio, que disputam territórios.

Os alunos bolsistas do PIBID possuíam uma preocupação em comum, que era trabalhar com as identidades dos alunos. Paralelamente, também havia a preocupação em trabalhar com as questões ambientais nessa escola, pois desde o primeiro instante era notável a perda da cultura e dos saberes dos sujeitos que vivem no campo. Com a industrialização, houve uma grande mudança na forma de produção, segundo Ghiraldelli (1990, pp. 81-5): “com a industrialização, os setores empresariais da indústria, do campo e dos bancos, aliado de um grupo de tecnocratas que Vargas foi criando, e dos militares, cederam à política de Vargas de aumentar o poder do Estado no sentido de regulamentar as relações de trabalho no país".

Percebem-se no campo dois grupos que disputam espaços: de um lado, o agronegócio, detentor de grande parte da tecnologia e com grande vontade de aumentar seus limites de terra para propagar o desenvolvimento, visto por esse grupo como necessário à economia; de outro lado, vê-se o campesinato lutando para sobreviver em meio às grandes dificuldades de existência encontradas tanto no território, quando se fala da terra, quanto nas limitações de se manter e viver sem adentrar em um mundo que se tornou inevitavelmente capitalista, onde o consumo dita a forma de trabalho.

No que se refere à questão ambiental, percebe-se que um dos principais eixos da Educação Ambiental que se faz presente é o de buscar a solidariedade, juntamente com o direito do cidadão, que se encontra vinculado ao lugar. Sendo assim, faz-se necessária a introdução de novas formas de atuação para o meio, 
em busca da criação de atitudes, de vivência e de comportamentos relacionados ao meio rural, envolvendo o coletivo. Pensa-se que, apontando-se os valores culturais do campo, os sujeitos que ali vivem tomariam para si o sentimento de pertencimento, e, dessa forma, aumentaria o seu desejo de fazer parte dessa comunidade, valorizando o meio, respeitando as crenças e as culturas do local.

Para que isso se torne possível, são essenciais a criação e o levantamento de projetos que visem à valorização do espaço vivido por sujeitos do campo. Esse pensamento coloca a educação como a formadora dos principais elementos de uma nova sociedade, e um desses aspectos é a sustentabilidade, que se refere não apenas ao meio ambiente, mas também à preocupação com os indivíduos que hoje residem no campo. Ressaltam-se, nesse contexto, a forma de relação do sujeito com o meio onde vive e a integração com o mundo. $\mathrm{O}$ mundo em que vivemos se encontra hoje dividido por diversos fatores e, por isso, merece ser abordado como um todo. Para concretizar essa afirmação, Trigueiro (2003, pp. 77-8) reage dizendo que

\begin{abstract}
No mundo moderno, onde o conhecimento encontra-se fragmentado, compartimentado em áreas que muitas vezes não se comunicam, a discussão ambiental resgata o sentido holístico, o caráter multidisciplinar que permeia todas as áreas do conhecimento, e nos induz a uma leitura da realidade onde tudo está conectado, interligado, relacionado.
\end{abstract}

Apontar essa realidade é como afirmar que nós mesmos não conseguimos sobreviver sem o auxílio do outro, e, ao interpretar essa noção, já estamos trabalhando a educação ambiental. A importância de apontar a realidade campestre e ambiental serve para que o aluno se junte, desde pequeno, na luta por melhorias das questões do campo, e isso só será concretizado se o aluno reagir diante das problemáticas apresentadas. Sendo assim, é de suma importância dentro de uma instituição de ensino, para que o aluno reaja às circunstâncias em que vive, dotá-lo de conhecimento da própria realidade, e essa realidade deverá ser abordada pela própria relação de contato e as relações existentes em outros cotidianos.

Pensa-se que, apontando-se as qualidades do campo, o sujeito entenderá melhor o contexto no qual vive e, consequentemente, valorizará as relações pessoais, firmando compromissos com o lugar no qual vive e deixando para trás toda a visão que hoje é colocada sobre o espaço rural: um espaço de atraso e de retrocesso. 
Figura 1: Mapa de localização da Escola de Ensino Fundamental Arroio Grande
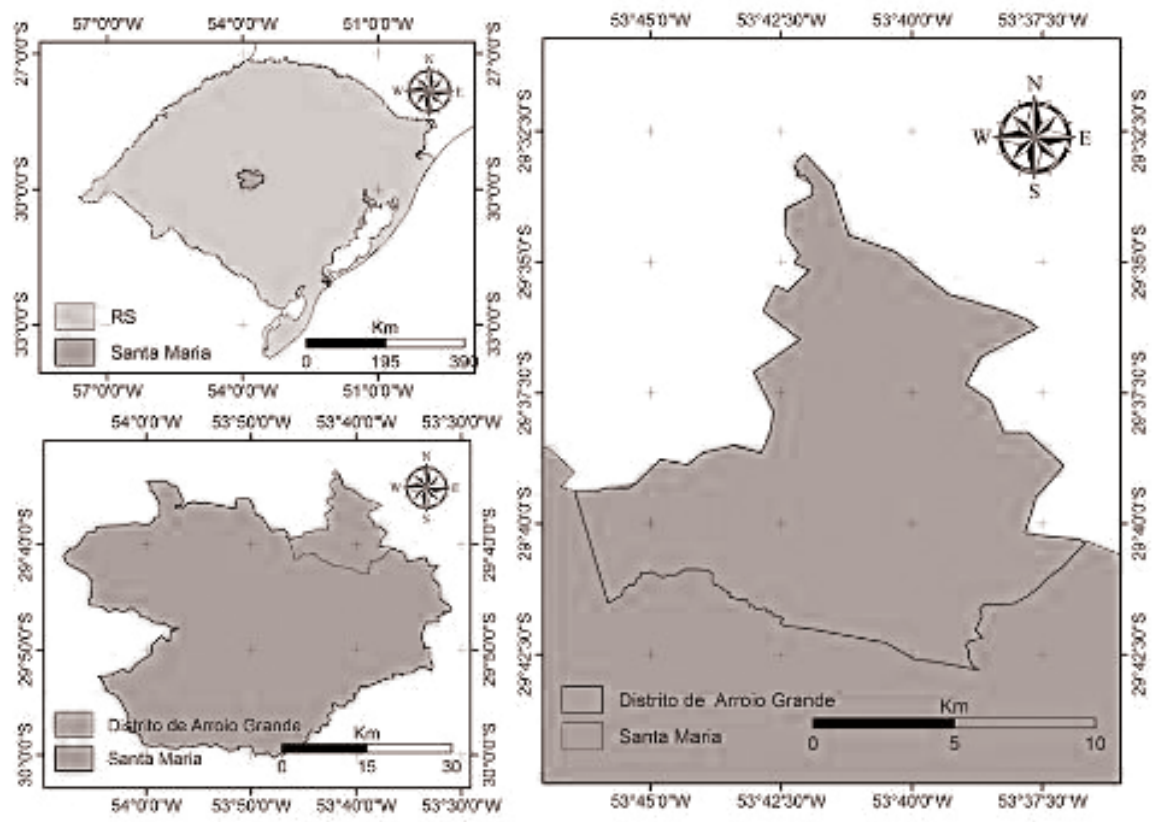

Inúmeros autores, como Leite (1999) e Calazans (1993), apontaram que a educação rural no Brasil, pelo menos até a década de 1990, quando incorporava uma categoria, já estava atrelada a um modelo de política econômica comprometida com as elites e ligada às oligarquias rurais. Percebe-se a Educação do Campo sendo constituída em um espaço de lutas dos movimentos sociais e sindicais do espaço rural. Em outras palavras, segundo o MEC (2002),

como uma concepção político pedagógica, voltada para dinamizar a ligação dos seres humanos com a produção das condições de existência social, na relação com a terra e o meio ambiente, incorporando os povos e o espaço da floresta, da pecuária, das minas, da agricultura, os pesqueiros, caiçaras, ribeirinhos, quilombolas, indígenas e extrativistas.

Diferentemente da Educação Rural, a Educação do Campo surge como ferramenta para a manutenção dos aspectos culturais locais. No entanto, para que seja uma educação que represente esses educandos, deve ser uma educação pautada na realidade dos indivíduos, com relevância para aspectos 
específicos e condições do lugar, valorizando o espaço vivido do educando. Nesse sentido, a paisagem natural deve ser levada em consideração e apreciada pelos alunos.

A educação voltada para as vivências dos alunos é capaz de fazer com que haja a transformação na educação do campo, bem como alterar a realidade vista hoje nesse lugar. Entender os alunos do campo é saber que a eles são associados alguns termos geralmente negativos, já que, para a sociedade atual, infelizmente, o espaço rural ainda é visto como um espaço de atraso. Nesse sentido, as Diretrizes Curriculares dispõem do seguinte entendimento: “ a cidade se consolidava como referência da modernização e do progresso, enquanto o campo representava o antigo e o rústico. $O$ próprio termo rural tem a mesma raiz de rústico e rude, enquanto o termo cidade dá origem a cidadão e cidadania” (Brasil, 1996).

Como não são diferentes no ambiente escolar urbano, as condições são relegadas a planos de segunda ordem, os materiais didáticos ainda são precário e os professores, sem a intenção de generalizar, como em toda a rede pública, não recebem a devida valoração. Descrevemos bem esses acontecimentos porque, na formação básica, ainda nas séries iniciais, fizemos parte da antiga educação do campo, quando as escolas eram multisseriadas, não nuclearizadas. Fui um dos últimos alunos da minha cidade a estudar na caracterizada escola do campo. Essas escolas, aos poucos, foram sendo fechadas, e os alunos do campo foram deslocados para escolas das cidades. Nesse ponto, percebe-se o início da perda cultural que se envolve nesse contexto; os alunos do meio rural necessitam e são merecedores de uma educação voltada à sua realidade, à totalidade do campo.

\section{Resultados}

\section{Atividades criadas e desenvolvidas pelo Projeto Interdisciplinar Educação do Campo}

A Escola Estadual de Arroio Grande se mostra preocupada com a sua função social. Então, fica visível que essa instituição de ensino tenta abordar questões que são de representatividade aos educandos, buscando a valorização do espaço-escola e do local onde esses sujeitos vivem. 
Figura 2: Oficina de alimentos preparados na cozinha da escola, com produtos retirados das propriedades dos pais ou familiares desses educandos, sendo possível, com isso, recriar receitas e resgatar parte da cultura local, que vem sendo perdida.

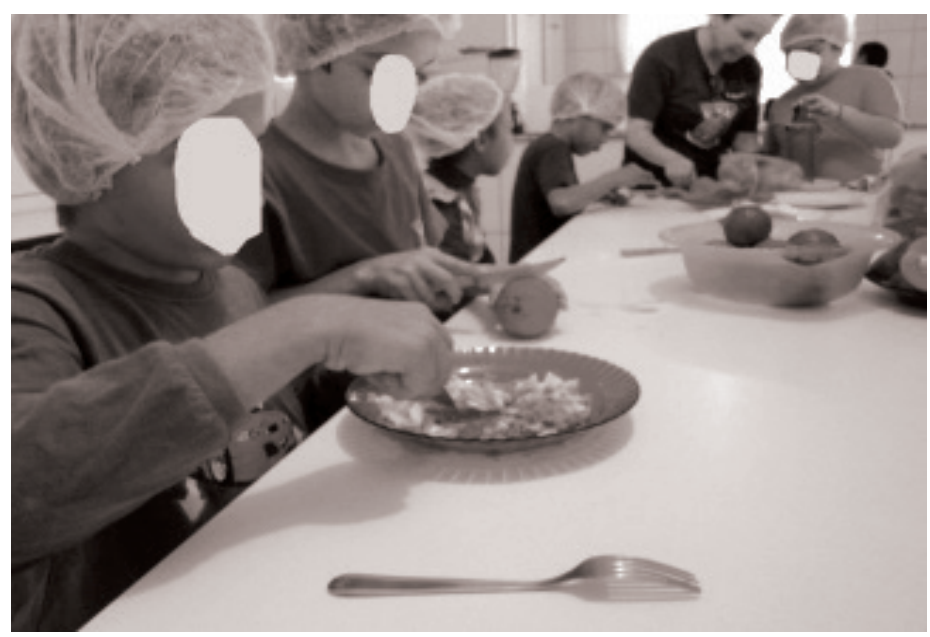

Fonte: os autores.

Figura 3: Sabendo das problemáticas do campo, onde se têm dados de que o uso de agrotóxicos é bastante elevado, tornou-se necessário discutir o papel deste veneno na vida desses educandos.

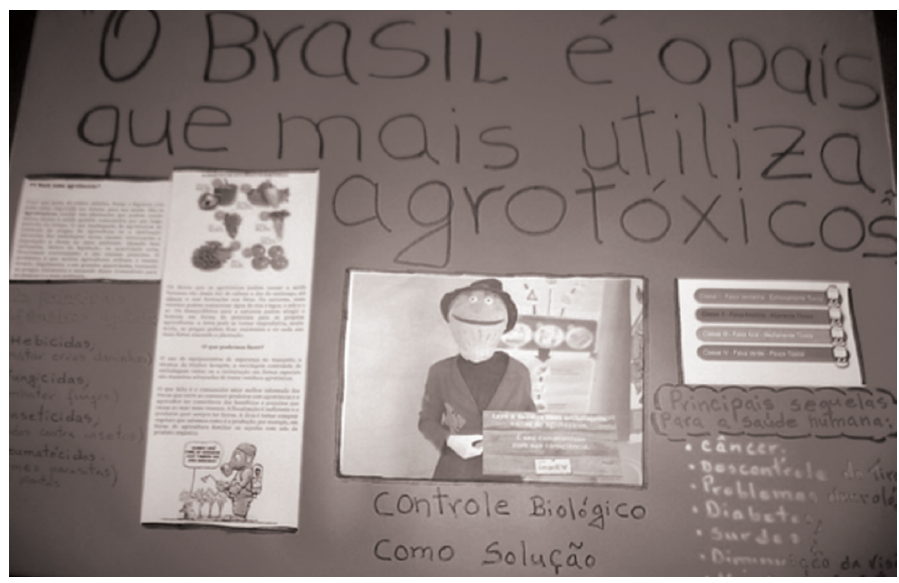

Fonte: os autores. 
Figura 4: Trazer os educandos para sua realidade é essencial. Para estes, foi trazido um olhar diferenciado ao lugar onde vivem. Na figura 4, é possível identificar a curiosidade dos educandos, quando foram mostradas a eles algumas imagens.

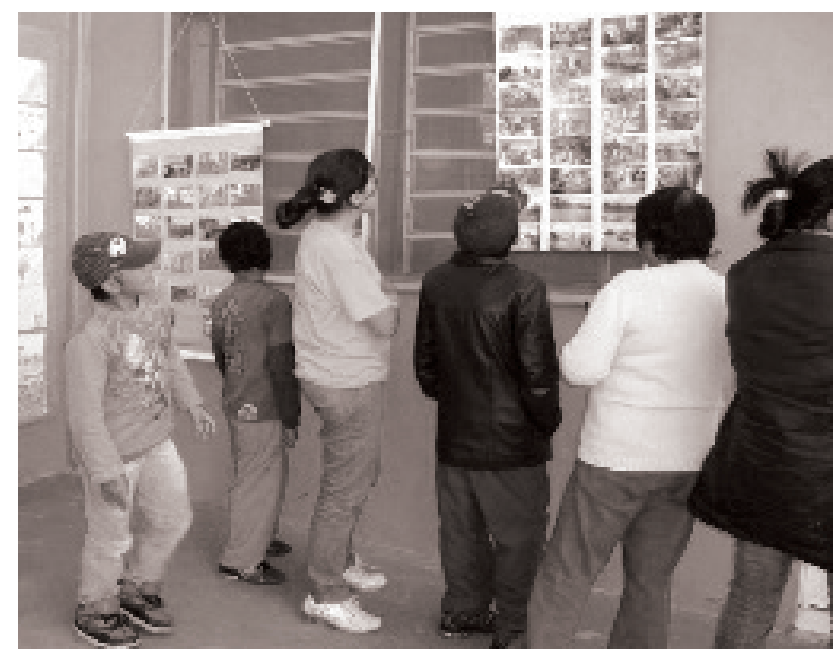

Fonte: os autores.

Figura 5: No que tange ao cotidiano dos educandos, foi possível perceber que muitos se encontravam incomodados por algumas questões e não colocavam para o grupo o que os motivava.

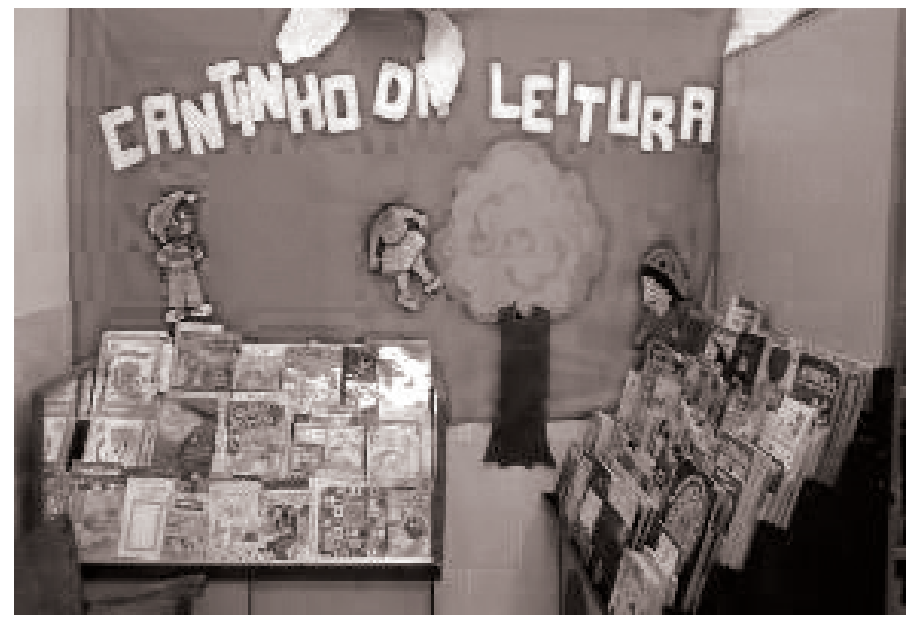

Fonte: os autores. 
Depois de um tempo, eles relataram que estavam passando por dificuldades em suas casas; alguns estavam envolvidos com substâncias ilícitas, gestação na adolescência, abuso sexual, entre outros aspectos. Pensando nisso e buscando criar um espaço de compreensão, de conversa, de entendimento e apoio, criou-se o espaço Cantinho da Leitura, um projeto que visava atender às demandas dos educandos de tal localidade. A metodologia seguia a partir da leitura de algum resumo, algumas revistas, alguns livros, músicas, documentários, filmes e histórias levadas pelos bolsistas, tudo para encorajar e abrir a discussão. Com o tempo, o Cantinho da Leitura foi substituído pelo Cantinho da Conversa.

Figura 6: $\mathrm{O}$ último projeto a ser implantado, enquanto eu participava, foi o projeto horta ou mandala. Ele possuía o propósito de inserir, de fato, os educandos no cotidiano do campo. Para tal projeto, foi preciso utilizar um espaço da escola que estava abandonado, coberto de britas (pequenos cascalhos). O primeiro passo foi limpar o espaço. Era preciso utilizar matemática para configurar os canteiros, que foram construídos com tábuas doadas por vizinhos. Nesse sentido, a bolsista de matemática configurou com os educandos as formas dos canteiros, utilizando formas geométricas para fazê-los. Os bolsistas de biologia e geografia fizeram a escolha das mudas que seriam plantadas ali (essas plantas foram trazidas da casa dos educandos). Enquanto eram escolhidas, era debatida a família da planta, bem como em que região do Brasil ou do país era encontrada. O pibidiano de língua portuguesa buscou os significados desta palavra nos diversos lugares do Brasil. 
Figura 6: Projeto horta ou mandala.

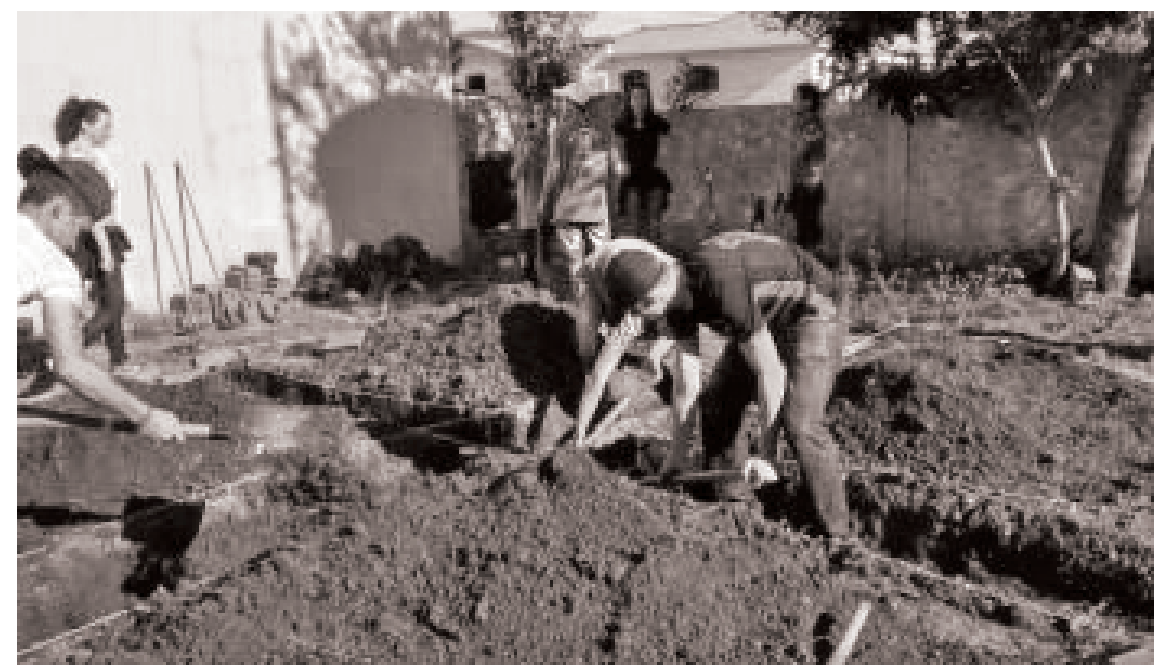

Fonte: os autores.

Ficou comprovado, dessa forma, que o ensino não convencional é uma alternativa construtiva, uma vez que prioriza o educando, trazendo-o para o centro, dotando-o de conhecimento a partir de suas vivências. Na sala de aula convencional, consegue-se visualizar educandos preocupados apenas em absorver conhecimento sem fazer as associações necessárias ao espaço onde vivem - há muita busca por excelentes notas, porém pouco interesse em compreender a finalidade real do aprendizado.

Esse fato é consequência da linha clássica empregada desde o ensino básico tradicionalmente urbano e, como não poderia ser diferente, postergado até as escolas do campo. Pensamos que projetos interdisciplinares conseguem fazer a mediação do aluno com o meio, uma vez que a temática da interdisciplinaridade é compreendida como uma forma de trabalhar em sala de aula, na qual se propõe um tema com abordagens em diferentes componentes curriculares. É construir algo inovador, que vise à ampliação de sabedorias bem como à incorporação de novas sabedorias, ultrapassando o pensar fragmentado. Nesse aspecto, o PIBID se mostra bastante atuante e comprometido com os alunos que abraça. 


\section{A interdisciplinar educação no campo e práticas pedagógicas na vida dos integrantes}

As lembranças estão bem claras. Lembro-me bem do dia em que a escola recebeu os participantes do grupo PIBID no início do ano de 2014 - a apresentação inicial foi repleta de timidez e incertezas, e já nesse primeiro dia houve contato com os alunos sala a sala, para que houvesse apresentação. A priori, foi possível detectar que as turmas se caracterizavam como tímidas e, de certo modo, curiosas em relação a nós, bolsistas pibidianos. Os primeiros questionamentos a serem feitos foram em torno de "o que significa o PIBID”, variando em "isso é um projeto?", "qual é a participação de vocês na escola (fora da sala)?”; e ao final: "vocês vão nos abandonar?”; o planejamento do estudo deu-se na sequência do levantamento do conteúdo abordado pelos professores da escola.

O PIBID Educação do Campo surge na minha vida acadêmica para complementar e contribuir com minha formação de licenciado. Minha trajetória dentro da licenciatura foi marcada pela participação em projetos de extensão e pesquisa.

As áreas de atuação nas quais fui me colocando desde a inserção na universidade giraram em torno das perspectivas de valorização cultural, educação do campo e educação ambiental. No PIBID, pude ter contato com oportunidades de colocar em prática em um só momento todos os temas abordados anteriormente, principalmente as concepções do campo, no que se diz respeito à educação nesse espaço.

Ao expormos nosso interesse em nos inserirmos no cotidiano do aluno, foram sendo ressaltadas algumas sensações que estavam escondidas em cada um que compunha o grupo. Essa experiência foi capaz de nos fazer despertar para o papel do professor, que deve ir além da formação de sala de aula, fora da universidade. Desse modo, haverá uma melhor preparação e capacitação do profissional.

Sendo assim, estar inserido dentro de sala de aula como participante deste Programa não é ser somente bolsista, é ser professor, é saber planejar e estar inserido no cotidiano dos educandos, importando-se com os acontecimentos em torno da realidade deles, que estão em busca de algo além de aprendizado sobre conteúdos.

Ao estar presente em sala de aula, pode-se notar que os educandos buscam uma formação social e espaço para se adequarem à sociedade, serem 
reconhecidos como cidadãos, e, nesse caso da educação do campo, em que a abordagem ocorre em volta de filhos de agricultores, eles merecem reconhecimento e respeito por serem agricultores também, caso optem por permanecer nesse lugar. Se desejarem sair, merecem ser respeitados na mesma proporção. Dessa forma, estudar a conjuntura da Educação desenvolvida no espaço rural é bastante complexa.

Com a participação do Grupo PIBID, pude, assim, perceber que a educação é e pode ser diferente. Foi possível verificar as possibilidades de engajamento entre professores, alunos e todo o grupo escolar. Obviamente que não posso dizer que só há coisas positivas onde o grupo está inserido, pois os professores ainda são discriminados por sua profissão e ainda há resistência por parte dos pais em participar do cotidiano dos alunos, inclusive fragmentação das estruturas físicas da escola.

O que se ressalta como bolsista, além da conexão interdisciplinar, é justamente o olhar que é direcionado a essas problemáticas; e além das conquistas já previstas, a luta para alcançar as melhorias é o que nos move, e é essa construção que fica marcada na nossa trajetória dentro do programa, não somente no curto período em que atuamos como bolsistas, mas também quando a levamos para a profissão. Ainda, existem em nós, esperanças de melhorias no que se refere tanto às atribuições de professores com sua devida valorização quanto à preocupação com os alunos que merecem um olhar marcado pelas dificuldades ainda encontradas na atual sociedade.

Um professor formado, que possua em seu currículo a participação em um grupo como o PIBID e, ainda, um projeto que ocorre de forma interdisciplinar, é capaz de transformar suas aulas, reinventar pedagogias e buscar novas formas de levar o aprendizado para além da sala de aula.

Hoje, graças a esse projeto, sou capaz de repensar minhas aulas, buscando novas maneiras de propor ao educando a participação que lhe interessa. Um projeto interdisciplinar faz sensibilizar a docência. A proposta de aproximação é marcada pelo contato aproximado entre aluno e professor; com isso, é conveniente verificar maior afinidade entre ambos, e isso significa crescimento, vontade e determinação. Assim, as aulas proporcionam um melhor aprendizado e aproveitamento.

Uma vez professor formado, existe uma maneira de manter-se com as concepções ativas adquiridas enquanto pibidiano. Dessa forma, é interessante manter-se em formação, sempre participando de projetos em que possa construir e buscar inovaçóes no ensino, formando-se continuadamente em prol do ensino de qualidade que os alunos merecem. 


\section{Referências}

BRASIL. Lei de Diretrizes e Bases da Educação Nacional. Brasília, 1996.

. Lei de Diretrizes e Bases da Educação Nacional, 2002. Disponível em: http:/www2.camara.leg.br/legin/fed/lei/1970-1979/lei-5692-11-agosto-1971-357752-publicacaooriginal-1-pl.html. Acesso em: 20 jan. 2017.

CALAZANS, Maria Julieta Costa. "Para compreender a educação do Estado no meio rural”. In DAMASCENO, Maria N. e THERRIEN, Jacques (orgs.). Educação e escola no campo. Campinas: Papirus, 1993.

FERNANDES, B. M. “Território camponês”. In: CALDART, R. S. et al. (orgs.). Dicionário da Educação do Campo. Rio de Janeiro: Escola Politécnica de Saúde Joaquim Venâncio. São Paulo: Expressão Popular, 2012. pp. $746-750$

e MOLINA, M. C. O campo da educação do campo. 2012. Disponível em: http://www2.fct.unesp.br/nera/publicacoes/ArtigoMonicaBernardoEC5.pdf.

et al. "Primeira Conferência Nacional 'Por uma educação básica do campo': texto preparatório”. In ARROYO, Miguel Gonzalez et al. (orgs.). Por uma educação do campo. Petrópolis: Vozes, 2004.

GHIRALDELLI, Luciana. et al. "Ectoparasites influence on the haematological parameters of Nile Tilapia and Carp cultured in the state of Santa Catarina, South Brazil". Journal of Fisheries and Aquatic Science, v. 1, n. 3, pp. 270-6, 2006.

LEITE, Sérgio Celani. Escola rural: urbanização e políticas educacionais. São Paulo: Cortez 1999.

SILVA, M. S. Educação do campo e desenvolvimento: uma relação construída ao 165 longo da história. 2004. Disponível em: http://www.contag.org. br/imagens/f299Educacao_do_Campo_e_Desenvolvimento_

Sustentavel.pdf. Acesso em: 31 mai. 2014.

TRIGUEIRO, André (coord). Meio ambiente na idade midia. Meio ambiente no século 21: 21 especialistas falam da questão ambiental nas suas áreas de conhecimento. Rio de Janeiro: Sextante, 2003. 


\title{
Trabalho e educação
}

\section{A qualificação de agricultores familiares por meio do Pronatec Campo}

\author{
Zenicleia Angelita Deggerone \\ Douglas Cenci
}

\section{Introdução}

A formação humana é todo o processo educativo que possibilita ao sujeito constituir-se enquanto ser social responsável e livre, capaz de refletir sobre suas atividades e ter autonomia para identificar e analisar as possibilidades de desenvolvimento. Em busca dessa autonomia enquanto sujeitos sociais, os agricultores familiares estão escrevendo uma nova história pelo apoio de políticas públicas sociais.

A inclusão de agricultores familiares no âmbito educacional inicia com a implementação da Lei n. ${ }^{\circ}$ 12.513, de 26 de outubro de 2011, que instituiu o Programa Nacional de Acesso ao Ensino Técnico e Emprego (Pronatec), com o objetivo de promover a inclusão social de jovens e trabalhadores do campo por meio da ampliação da Rede Federal de Educação Profissional e Tecnológica e da oferta de cursos de formação inicial e continuada para trabalhadores, de acordo com os arranjos produtivos rurais de cada região (Brasil, 2011).

A criação do Pronatec Campo amplia as oportunidades educacionais para todas as pessoas que trabalham e vivem no campo, além de fazer a articulação da educação profissional tecnológica com as políticas de geração de emprego e renda oportunizadas pelo Governo Federal, pois a nova ruralidade formada por agricultores familiares é responsável pela produção de alimentos, preservação das tradições, conhecimentos, culturas, saberes e manutenção dos espaços rurais. Essas novas características remetem à necessidade de novos arranjos organizacionais, a partir da busca constante de informação, 
conhecimento, tecnologia, a fim de permitir que os agricultores continuem residindo e trabalhando no meio rural (Deggerone et al., 2014).

Sendo assim, o objetivo geral desta pesquisa é conhecer a experiência do Programa Nacional de Acesso ao Ensino Técnico e Emprego (Pronatec Campo) na qualificação de agricultores familiares associados ao Sindicato Unificado dos Trabalhadores na Agricultura Familiar no Alto Uruguai Sutraf-AU. Especificamente, pretende-se com esta pesquisa:

a. Apresentar o Pronatec Campo;

b. Identificar os cursos de qualificação e o número de vagas oferecidas pelo Pronatec Campo para a qualificação dos agricultores familiares;

c. Verificar junto ao Sutraf-AU, discentes e docentes a importância da qualificação de agricultores familiares.

Os procedimentos metodológicos adotados nesta pesquisa envolveram uma abordagem qualiquantitativa, tendo por objetivo realizar uma pesquisa descritiva exploratória. Segundo Borba (2001), a pesquisa qualitativa permite compreender os sujeitos pesquisados em uma visão ampla. Ou seja, além de computar dados, a pesquisa quantitativa direciona a visualização do público, em sua prática social.

Na pesquisa quantitativa, segundo Fonseca (2002), os resultados podem ser quantificados e se centram na objetividade. A utilização conjunta da pesquisa qualitativa e quantitativa permite recolher mais informações do que se obteria de forma isolada.

Os procedimentos técnicos adotados nesta pesquisa são de natureza bibliográfica, de consultas documentais e do levantamento de informações junto ao Instituto Federal de Educação, Ciência e Tecnologia do Rio Grande do Sul - IFRS -, campus Erechim, e do Sutraf-AU.

Também foram realizadas entrevistas semiestruturadas junto aos coordenadores das entidades, supervisores, docentes e discentes, a fim de subsidiar maiores informações acerca da experiência em educação profissional no campo. 


\section{A qualificação de jovens e agricultores familiares}

Na agricultura familiar, é a família a responsável pela guarda e transmissão às novas gerações do conhecimento que resulta da experiência. Contudo, Rodrigues (1984) aborda a relação contraditória entre o trabalho agrícola e o conhecimento científico associado à moderna tecnologia, em que se confrontam os saberes acumulados pelos anos de experiência e o conhecimento novo e estranho, que, porém, os camponeses reconhecem como necessário. Associado à introdução dos implementos agrícolas modernos, pela aplicação planejada e controlada da tecnologia assentada em bases científicas, esse conhecimento substitui os métodos tradicionais do trabalho agrícola, geradores de saberes que são transmitidos de pai para filho (Marx, 1998).

Contudo, Ribeiro (2013) atenta que uma nova educação e formação deve emergir visando à formação dos filhos e dos agricultores, que buscam enfrentar os desafios da produção agropecuária e da vida contemporânea. Associada à constituição de relações sociais democráticas e solidárias, a educação do campo articula-se com o trabalho cooperativo e a autogestão na perspectiva de uma produção em harmonia com os seres humanos e a natureza.

Sendo assim, na busca de oportunizar a qualificação de jovens e agricultores familiares, de modo integrador e emancipatório, foi instituído o Pronatec, que tem como finalidade ampliar a oferta de educação profissional e tecnológica por meio de programas, projetos e ações de assistência técnica e financeira. Entre os objetivos do Programa estão:

I - expandir, interiorizar e democratizar a oferta de cursos de educação profissional técnica de nível médio presencial e a distância e de cursos e programas de formação inicial e continuada ou qualificação profissional; II - fomentar e apoiar a expansão da rede física de atendimento da educação profissional e tecnológica;

III - contribuir para a melhoria da qualidade do ensino médio público, por meio da articulação com a educação profissional;

IV - ampliar as oportunidades educacionais dos trabalhadores, por meio do incremento da formação e qualificação profissional;

$\mathrm{V}$ - estimular a difusão de recursos pedagógicos para apoiar a oferta de cursos de educação profissional e tecnológica (Brasil, 2011, p. 1). 
No segundo artigo da Lei, o Pronatec institui uma política de atendimento prioritário, em que considera as seguintes categorias: estudantes do ensino médio da rede pública, inclusive da educação de jovens e adultos; trabalhadores em geral; beneficiários dos programas federais de transferência de renda; estudantes que tenham ensino médio completo em escola da rede pública ou em instituições privadas na condição de bolsista integral, nos termos do regulamento. Ressalta-se que na categoria de trabalhadores se incluem os agricultores familiares, silvicultores, aquicultores, extrativistas e pescadores.

Sendo assim, o programa se configura por desenvolver ações visando ao atendimento de jovens e trabalhadores, atuando na qualificação profissional, e, consequentemente, repercute no acesso a melhores oportunidades de emprego. O resultado imediato é no acesso às informações, no desenvolvimento pessoal, na remuneração e no crescimento da economia local.

De acordo com o art. 4. da Lei 12.513/2011, posteriormente alterado pela Lei 12.816/2013, o Pronatec é desenvolvido por meio de dez ações: a) ampliação de vagas e expansão da rede federal de educação profissional e tecnológica; b) ampliação de vagas e a expansão das redes estaduais de educação profissional; c) incentivo à ampliação de vagas e à expansão da rede física de atendimento dos serviços nacionais de aprendizagem; d) oferta de bolsa-formação nas modalidades Bolsa-Formação Estudante e Bolsa -Formação Trabalhador; e) financiamento da educação profissional e tecnológica; f) fomento à expansão da oferta de educação profissional técnica de nível médio na modalidade de educação a distância; g) apoio técnico voltado à execução das ações desenvolvidas no âmbito do Programa; h) estímulo à expansão de oferta de vagas para as pessoas com deficiência, inclusive com a articulação dos Institutos Públicos Federais, Estaduais e Municipais de Educação; i) articulação com o Sistema Nacional de Emprego; e j) articulação com o Programa Nacional de Inclusão de Jovens - Projovem (Brasil, 2013a).

Nesse mesmo artigo, no inciso 4, é apresentada a forma de financiamento da formação profissional. O subsídio ocorre por meio da oferta da Bolsa -Formação, e ela é oferecida nas duas modalidades: Bolsa-Formação Trabalhador e Bolsa-Formação Estudante.

A Bolsa-Formação Trabalhador corresponde ao financiamento de cursos de qualificação, ou seja, formação inicial e continuada (FIC). Essa modalidade é destinada para trabalhadores e pessoas atendidas pelos programas de transferência de renda do governo federal. Já a Bolsa-Formação Estudante corresponde ao financiamento de cursos técnicos de nível médio (concomi- 
tante ou subsequente) e também cursos de formação inicial e continuada. Os cursos concomitantes são destinados aos alunos regularmente matriculados no ensino médio; para os egressos, são os cursos subsequentes.

No art. 5., o Pronatec considera modalidades de educação profissional e tecnológica os cursos de formação inicial e continuada ou qualificação profissional e de educação profissional técnica. Os cursos de formação inicial continuada estão relacionados no Guia de Cursos Pronatec FIC, ${ }^{1}$ elaborado pelo Ministério da Educação, e os cursos de educação profissional técnica de nível médio são submetidos às diretrizes curriculares nacionais definidas pelo Conselho Nacional de Educação, bem como às demais condições estabelecidas na legislação aplicável, devendo constar do Catálogo Nacional de Cursos Técnicos, organizado pelo Ministério da Educação (Brasil, 2013).

\section{A qualificação de agricultores familiares por meio do Pronatec Campo}

O Pronatec Campo é ofertado no âmbito do Programa Nacional de Educação do Campo (Pronacampo), por meio do Ministério do Desenvolvimento Agrário (MDA) e o Ministério da Educação (MEC). Essas instituições em parceria organizam a Bolsa-Formação Pronatec Campo, por meio da qual são ofertados os cursos de educação profissional e tecnológica para os públicos da agricultura familiar, povos e comunidades tradicionais e da reforma agrária, conforme a Lei da Agricultura Familiar. ${ }^{2}$

É importante salientar que os beneficiários da Bolsa-Formação possuem direito ao curso gratuito e com qualidade, além da garantia da alimentação,

\footnotetext{
${ }^{1}$ Aprovado pela Portaria n. ${ }^{\circ}$ 1.568, de 3 de novembro de 2011, e elaborado pela Secretaria de Educação Profissional e Tecnológica do Ministério da Educação. A versão atual conta com 518 opções de curso, distribuídos em 13 eixos tecnológicos, conforme suas características científicas e tecnológicas.

${ }^{2}$ De acordo com a Conferência Nacional de ATER, realizada em abril de 2012, toda vez que se tratar da agricultura familiar e/ou dos povos e comunidades tradicionais e/ou das mulheres do campo, da floresta e das águas, compreende-se como sendo a diversidade dos seguintes segmentos: agricultura familiar tradicional, camponeses, acampados, assentados da reforma agrária, povos de terreiro e ciganos/as, quilombolas, açorianos, atingidos por barragens, mineradoras e hidrelétricas, extrativistas, seringueiros/as, quebradeiras de coco, fundos de pasto, faxinalenses, pescadores/as artesanais, ribeirinhos/as, aquicultores/as familiares, caiçaras, marisqueiros/as, retireiros/as, torrãozeiros/as, geraizeiros/as, vazanteiros/as, pomeranos/as, pantaneiros/as, caatingueiros/as (MDA, 2012).
} 
do transporte e acesso a todos os materiais escolares necessários que possibilitarão a sua posterior inserção profissional.

A implementação do Pronatec Campo ocorreu mediante a parceria instituída entre MDA e MEC, em que concedem a oferta gratuita de cursos de formação inicial e continuada ou qualificação profissional, por meio da Bolsa-Formação Trabalhador, e de educação profissional técnica de nível médio, por meio da Bolsa-Formação Estudante.

A partir desse contexto, o MDA realizou convênios com diversas instituições, e uma delas foi a Federação dos Trabalhadores na Agricultura Familiar (Fetraf-Sul), que abrange o Sutraf-AU, objeto deste estudo, em que articulou e demandou a oferta de cursos no âmbito da região Alto Uruguai e busca, entre as demandas da agricultura familiar, cursos para o atendimento das necessidades dos agricultores familiares.

Além desse convênio com as entidades representativas da agricultura familiar, foi estabelecido um acordo com os parceiros ofertantes, ou seja, os Institutos Federais, escolas vinculadas às universidades federais, CEFET e redes estaduais, sendo tais instituições responsáveis pela realização dos cursos. A essas couberam a pactuação, a oferta de cursos e a organização de recursos materiais, humanos e logísticos para viabilização da oferta.

Nesse caso, na região Alto Uruguai, o Sutraf-AU realizou essa parceria institucional junto ao IFRS - campus Erechim. Nele, coube à organização sindical a responsabilidade de demandar os cursos e organizar as respectivas turmas, e ao IFRS foram delegados a disponibilização de materiais, a organização do quadro de docentes, o apoio pedagógico e administrativo ao desenvolvimento das atividades.

O Sutraf-AU constitui-se uma entidade que representa a agricultura familiar em toda a região Alto Uruguai, implementando atividades que promovem o desenvolvimento local por meio de ações de geração de renda, cooperativismo, associativismo, preservação ambiental e valorização sociocultural. O Sindicato também atua na redução das desigualdades sociais, na valorização do trabalho da mulher agricultora e fomenta a permanência de jovens no meio rural.

Para Seminotti (2014), essa organização sindical propõe uma nova forma de atuação junto aos agricultores familiares, com um olhar voltado para a produção e para as políticas públicas com base em uma nova organização sindical interna. Essa proposta busca o desenvolvimento local por meio de ações 
endógenas, das quais o agricultor seja protagonista daquelas que venham beneficiar suas comunidades e o meio rural.

O IFRS - campus Erechim desenvolve suas atividades, oferecendo cursos técnicos, na modalidade subsequente, em Técnico em Alimentos, Finanças, Logística, Mecânica e Modelagem do Vestuário. No ensino superior, atua ministrando os cursos de Engenharia de Alimentos, Engenharia Mecânica, Tecnologia em Design de Moda e Tecnologia em Marketing.

A implantação do Instituto Federal em Erechim buscou atender à necessidade da institucionalização da educação profissional e tecnológica, estabelecendo o compromisso de integrar a diversidade social, econômica, geográfica e cultural, na necessidade de redução das desigualdades regionais, na elevação do nível de escolaridade e na capacitação tecnológica da população.

Conforme o Guia Pronatec, nos cursos FIC são oferecidas 644 oportunidades de qualificação, e dentro do eixo tecnológico de recursos naturais, que são cursos voltados para o setor rural, são oferecidos 60 cursos, que compreendem as tecnologias relacionadas à produção animal, vegetal, mineral, aquícola e pesqueira. Além disso, abrangem ações de prospecção, avaliação técnica e econômica, planejamento, extração, cultivo e produção referente aos recursos naturais. Inclui, ainda, a tecnologia de máquinas e implementos, estruturada e aplicada de forma sistemática para atender às necessidades de organização e produção dos diversos segmentos envolvidos, visando à qualidade e sustentabilidade econômica, ambiental e social (Pronatec, 2013b).

O curso FIC Agricultor Familiar foi concebido e organizado de maneira a atender o disposto no Guia Pronatec de cursos FIC. Segundo esse curso, o profissional trabalhador na agricultura familiar deverá apresentar as seguintes competências: produzir em propriedades rurais de pequeno e médio porte; articular e envolver a família na produção agrícola e animal; estruturar e se organizar para produzir para a alimentação escolar; e analisar as redes sociais e econômicas que garantam a sustentabilidade no meio rural (IFRS, 2013a).

Conforme o projeto pedagógico do curso de Agricultor Familiar, o curso foi organizado em sete módulos. Os dois primeiros módulos correspondem a um grupo de disciplinas que compreendem uma formação básica ao discente: Orientação Profissional e Cidadania, e Matemática. Também faz parte do desenho curricular a formação específica que contempla a multidisciplinaridade, como: Agroecologia, Gestão da Propriedade; Associativismo, Cooperativismo e Economia Solidária; Custos de Produção; e Organização 
da Propriedade. Essas disciplinas possibilitam ao discente uma formação generalista, porém sem perder a especificidade das áreas temáticas de maior interesse da agricultura familiar (IFRS, 2013a).

O desenvolvimento das atividades do Pronatec Campo ficaram regidas pelo IFRS - campus Erechim. Essa instituição organizou a oferta dos cursos, os recursos materiais e logísticos, bem como a contratação dos docentes. As organizações sindicais atuaram na divulgação dos cursos, das vagas, na organização da turma e na matrícula dos discentes, além de disponibilizar a sala de aula usada para a realização dos encontros, ou seja, as aulas eram realizadas nos municípios que haviam solicitado o curso, e os docentes contratados pelo IFRS - campus Erechim se deslocavam para os municípios para ministrarem as aulas.

No ano de 2013, por meio da parceria estabelecida entre o IFRS - campus Erechim e o Sutraf-AU, foi ofertado o curso de Agricultor Familiar nos municípios de Aratiba, Itatiba do Sul e São Valentim, conforme se verifica na tabela 1 .

Tabela 1: Vagas ofertadas em 2013 e discentes formados no curso de Agricultor Familiar

\begin{tabular}{|l|c|c|}
\hline Município & Vagas pactuadas & Discentes formados \\
\hline Aratiba & 35 vagas & 17 formados \\
\hline Itatiba do Sul & 40 vagas & 18 formados \\
\hline São Valentim & 30 vagas & 16 formados \\
\hline Total & 105 vagas & 51 formados \\
\hline
\end{tabular}

Fonte: IFRS, 2013b.

Em relação aos dados do ano de 2013 do Pronatec na região Alto Uruguai, verifica-se que apenas $48 \%$ da meta pactuada foi atendida. Já a tabela 2, apresenta o número de vagas ofertadas nos municípios de Erval Grande, Paulo Bento e Viadutos, e discentes formados no curso de Agricultor Familiar no ano de 2014. 
Tabela 2: Vagas ofertadas em 2014, e discentes formados no curso de Agricultor Familiar

\begin{tabular}{|l|c|c|}
\hline Município & Vagas pactuadas & Discentes formados \\
\hline Erval Grande & 22 vagas & 11 formados \\
\hline Paulo Bento & 25 vagas & 07 formados \\
\hline Viadutos & 20 vagas & 11 formados \\
\hline Total & $\mathbf{6 7}$ vagas & $\mathbf{2 9}$ formados \\
\hline
\end{tabular}

Fonte: IFRS, 2014b.

Em relação ao ano de 2014, um percentual de 43\% dos alunos concluiu o curso de Agricultor Familiar, nos municípios em que esse curso foi ofertado. Pode-se perceber que, em ambos os anos, o mesmo curso formou poucos discentes e, no último ano, teve um decréscimo no número de formados. Conforme o resultado obtido, podem ser identificadas algumas dificuldades que interferiram no rendimento dos discentes, conforme os relatos:

Dificuldades de concentração de alguns alunos, o horário estendido o que para os agricultores é cansativo, por isso as aulas deveriam ter sido mais dinâmicas em alguns módulos do curso (EA, 12/12/2014, p. 1).

O tempo de duração das aulas, um pouco puxado para quem trabalha durante o dia, e a noite participar das aulas cansado dificulta o aprendizado, e a atenção durante as aulas (EB, 13/12/2014, p. 1).

Em relação aos depoimentos, é possível compreender as dificuldades de conciliar os trabalhos na agricultura e as aulas no período da noite, pois, para o agricultor familiar, torna-se exaustiva a permanência em sala de aula por quatro horas consecutivas. O curso de agricultor familiar oferece 200 horas/ aulas, numa média de 8 horas por semana, sendo dois dias da semana de aula, por 22 semanas conseguintes. Isso exige dos discentes o planejamento das atividades na propriedade rural e empenho para concluir o curso, pois os trabalhos na agricultura em determinadas épocas do ano ocorrem em um ritmo maior, culminando nos trabalhos de preparo do solo, plantio e colheita, o que demanda maior tempo para as tarefas na propriedade rural e acaba deixando para um segundo plano a dedicação aos estudos. 
Já em outras atividades produtivas, como a bovinocultura leiteira, avicultura e suinocultura, estas exigem uma rotina de constantes cuidados e monitoramento das tarefas, no que se refere aos períodos de alimentação, manejo, e limpeza das instalações, entre outras tarefas, o que em determinados momentos pode interferir na qualidade da participação das aulas.

Porém, é possível identificar o empenho dos docentes em ministrar aulas com diferentes métodos de ensino, aliadas à realização das aulas práticas e visitas técnicas.

As dinâmicas fizeram com que todos os alunos se envolvessem; os momentos em que alunos demonstraram seu interesse pelos temas em debate participando e colocando suas opiniões. Os intercâmbios e visitas mostram os resultados na prática (EB, 13/12/2014, p. 1).

Como os discentes possuíam faixas etárias diferentes, já chegavam exaustos para participar da aula, então as aulas eram diversificadas, onde eram usados métodos de ensino diferenciados, que envolveram dinâmicas de grupo, vídeos, músicas, brincadeiras, exercícios, leituras dirigidas e aulas expositivas dialogadas (EE, 16/12/2014, p. 1).

Nesse caso, é importante salientar que o uso de diferentes metodologias em sala de aula é uma das mais importantes táticas usadas para despertar o interesse e a atenção dos alunos. Para Gil (1994), motivar os alunos não significa contar piadas, mas identificar quais os interesses do aluno para o conteúdo ou tema, sendo necessário estabelecer um "relacionamento amistoso com o aluno”. Somente assim é possível motivá-lo para o aprendizado.

Isso pode ser feito mediante a apresentação do conteúdo, de maneira que os alunos se interessem em descobrir a resposta, queiram saber o porquê, e assim por diante. Convém também que o professor demonstre o quanto a matéria pode ser importante para o aluno (Gil, 1994).

Portanto, cabe ao professor criar alternativas. Masetto (1997, p. 35) ressalta que "a sala de aula deve ser vista como espaço de vivência". Quando o aluno percebe que pode estudar nas aulas, discutir, encontrar pistas e encaminhamentos para questôes de sua vida e das pessoas que constituem seu grupo vivencial, quando seu dia a dia de estudos é invadido e atravessado pela vida, quando ele pode sair da sala de aula com as mãos cheias de dados, com contribuições significativas para os problemas que são vividos "lá fora", esse 
espaço se torna espaço de vida, assume um interesse peculiar para ele e para seu grupo de referência.

Dessa forma, além de ser um lugar de pesquisa para o professor, é também um espaço formador para o aluno, onde ele pode aprender a refletir melhor as ideias e a ressignificar suas concepções.

O segundo curso oferecido pelo IFRS - campus Erechim em parceria com o Sutraf-AU foi o curso de Bovinocultor de Leite, que buscou capacitar agricultores familiares para desenvolver a atividade leiteira, abrangendo os aspectos ambientais, econômicos e sociais, dentro de um sistema que contemple sistematicamente solo/planta/animal. Além disso, o curso contribui na formação de agentes de transformação, analisando as potencialidades das unidades de produção familiares, e nas formas de promover o desenvolvimento pleno da atividade leiteira nas propriedades rurais (IFRS, 2014a).

Segundo o projeto pedagógico do Curso de Bovinocultor de Leite, este foi organizado em dois módulos, sendo o primeiro correspondente a disciplinas que oferecem uma formação básica ao discente, como a Orientação Profissional e Cidadania. E a formação específica contempla a multidisciplinaridade por meio das disciplinas de anatomia animal; planejamento da alimentação animal; homeopatia aplicada à bovinocultura leiteira; gestão da propriedade; e organização da propriedade. Essas disciplinas possibilitam ao discente uma formação generalista, porém sem perder a especificidade das áreas temáticas de maior interesse do bovinocultor de leite (IFRS, 2014a).

A tabela 3 apresenta o número de vagas ofertadas em 2014, nos municípios de Aratiba e Severiano de Almeida, e o número de discentes formados.

Tabela 3: Vagas ofertadas em 2014, e discentes formados no Curso de Bovinocultor de Leite

\begin{tabular}{|l|c|c|}
\hline Município & Vagas pactuadas & Discentes formados \\
\hline Aratiba & 20 vagas & 19 formados \\
\hline Severiano de Almeida & 25 vagas & 18 formados \\
\hline Total & 45 vagas & 37 formados \\
\hline
\end{tabular}

Fonte: IFRS, 2014c. 
Com base dos resultados, é possível verificar que nesse curso o número de formados chegou a $82 \%$. Tal resultado foi obtido devido aos relatos dos discentes, à qualidade das aulas ministradas e às metodologias usadas em sala de aula, como se pode perceber:

O auxílio assíduo dos professores para com os alunos com mais dificuldades; os intercâmbios realizados (aulas práticas); as dinâmicas realizadas em aulas; as práticas didáticas diferenciadas que favoreciam o aprendizado, a apresentação de soluções para problemas relatados pelos alunos, e a troca de conhecimentos (tanto com professor tanto com demais estudantes) (ED, 15/12/2014, p. 1).

O debate dos assuntos com os professores e colegas, podendo trocar experiências (EB, 13/12/2014, p. 1).

Dessa forma, é possível considerar que as práticas educativas possibilitaram o envolvimento e compromisso social por meio do respeito e a integração do saber produzido coletivamente entre discentes e docentes. O saber contextualizado permite uma melhor compreensão da realidade, que caminha para a identificação de possíveis soluções dos problemas comunitários e se amplia para a compreensão e a transformação da base das estruturas sociais e econômicas.

Além disso, os discentes reportam sobre a relação teórico-prática - o conhecimento apreendido em sala de aula foi possível de ser implementado em suas unidades produtivas, conforme os relatos:

É possível aplicar na propriedade, afinal todos os conhecimentos obtidos são de fácil entendimento e possíveis a serem colocados em prática (EA, 12/12/2014, p. 1).

A gente pode melhorar as coisas sendo possível adaptar os novos conhecimentos adquiridos nas aulas para a nossa propriedade (EB, 13/12/2014, p. 1).

Os conteúdos ministrados nos diversos módulos tratavam das propriedades rurais, onde eram apresentadas soluções diferenciadas para as diferen- 
tes categorias produtivas, e trouxeram resultados positivos para a unidade produtiva, não somente na questão financeira, mas também em qualidade do trabalho e bem-estar dos produtores (ED, 15/12/2014, p. 1).

Sendo assim, por meio do curso realizado, a principal característica apontada pelos discentes em suas considerações está relacionada com a aplicabilidade dos conhecimentos em suas unidades de produção familiares. Ou seja, os conteúdos estudados em sala de aula eram postos na prática em suas atividades produtivas, o que contribuiu para o desenvolvimento individual, social e econômico de suas propriedades rurais e na vida comunitária.

Corroborando com esse resultado, os autores Frigotto et. al, (2005) reconhecem que a formação é a chave para o trabalhador apreender as contradições das relações sociais de produção e produzir sua existência com o seu trabalho. Não é por adaptação à realidade dada que os trabalhadores devem se conformar com a situação posta, mas devem confrontar essa realidade e buscar a sua transformação.

Nas palavras de Freire, a formação deve motivar a autonomia, ou seja, uma educação que supõe o respeito às diferenças, aberta à comunicação com o outro, com o diferente (2000, p. 42). Além disso, o autor considera que uma educação que visa estimular a autonomia possibilita as condições para que os educandos possam "assumir-se". Isso envolve assumir a condição sócio-histórica, a condição de ser pensante, comunicante, transformador, criador, sonhador, etc.

Diante disso, Oliveira (2003) analisa que uma das questões centrais na relação entre demanda por competência profissional e conhecimento diz respeito à capacitação de produtores rurais, agricultores familiares e de trabalhadores rurais em novas técnicas de produção, inovações tecnológicas e de gestão. Pois, diante do histórico de exclusão desses atores do quadro de inovação, são necessárias políticas que possam inseri-los no acesso à diversificação de conhecimentos, de modo a incorporarem novas técnicas que resultem em incremento na produção, melhoria da qualidade dos produtos, bem como acesso ao mercado e, portanto, maior competitividade do setor, proporcionando-lhes melhorias na qualidade de vida. 


\section{Considerações finais}

A realização deste trabalho permitiu inferir que a formação humana possibilita aos sujeitos constituírem-se enquanto seres sociais responsáveis e livres, sendo capazes de refletir sobre suas atividades, serem autônomos para identificar e analisar as possibilidades de desenvolvimento. Essa busca foi possibilitada mediante a inclusão de agricultores familiares no âmbito educacional, com a implementação da Lei n. ${ }^{\circ}$ 12.513, de 26 de outubro de 2011, em que foi instituído o Programa Nacional de Acesso ao Ensino Técnico e Emprego (Pronatec).

O Pronatec teve por finalidade ampliar a oferta de educação profissional e tecnológica por meio de programas, projetos e ações de assistência técnica e financeira, além de apoiar a expansão da rede física de atendimento à educação profissional e tecnológica, contribuindo para a melhoria da qualidade do ensino médio público, mediante a articulação com a educação profissional e a ampliação das oportunidades educacionais dos trabalhadores com o incremento da formação e qualificação profissional.

Percebeu-se que, entre suas principais prerrogativas, o Pronatec desenvolve ações visando ao atendimento prioritário de jovens e trabalhadores, além de conceder a oferta da Bolsa-Formação, que garante o direito ao curso gratuito, à alimentação, ao transporte e aos materiais escolares.

A experiência do Pronatec Campo na região Alto Uruguai, no Rio Grande do Sul, se deu mediante a parceria institucional entre o Sutraf-AU e o IFRS - campus Erechim. À organização sindical coube a responsabilidade de demandar os cursos e organizar as respectivas turmas nos municípios, e ao IFRS - campus Erechim, a disponibilização de materiais, a organização do quadro de docentes, o apoio pedagógico e administrativo para o desenvolvimento das atividades.

Verificou-se que na região Alto Uruguai foi implementado, no ano de 2013, o curso de Agricultor Familiar nos municípios de Aratiba, Itatiba do Sul e São Valentim, formando 51 agricultores familiares, cumprindo $48 \%$ da meta pactuada. Em 2014, foram dois cursos disponibilizados, sendo o curso de Bovinocultor de Leite realizado nos municípios de Aratiba e Severiano de Almeida e formando 37 agricultores familiares, atingindo $83 \%$ da meta pactuada. O segundo curso disponibilizado foi novamente o curso de Agricultor Fami- 
liar, nos municípios de Erval Grande, Paulo Bento e Viadutos, formando 29 agricultores, cumprindo $43 \%$ da meta inicial pactuada.

Considerando esses dados, foi possível fazer um diagnóstico, apontando-se alguns pontos negativos e positivos sobre o desenvolvimento dos cursos. Sobre os aspectos negativos, podem ser consideradas as dificuldades de conciliar os trabalhos na agricultura e as aulas no período da noite, pois para o agricultor se torna cansativa e exaustiva a permanência em sala de aula se as aulas não forem diversificadas por meio de dinâmicas de grupo, vídeos, músicas, brincadeiras, exercícios, leituras dirigidas e aulas expositivas dialogadas.

Entre os aspectos positivos, podem ser elencadas as diferentes práticas metodológicas usadas para ministrar os conhecimentos. Elas estão relacionadas ao auxílio assíduo dos professores para com os alunos com maiores dificuldades, aos intercâmbios realizados, às dinâmicas grupais e à troca de conhecimentos entre discentes e docentes.

Além do mais, entre os principais pontos positivos está a relação da aplicação da teoria na prática, ou seja, os conteúdos estudados em sala de aula eram postos na prática em suas atividades produtivas, o que contribuiu com desenvolvimento individual, social e econômico de suas propriedades rurais e na vida comunitária dos agricultores familiares.

Sendo assim, a educação deve abranger os processos formativos que desenvolvem a vida familiar, na convivência humana, no trabalho, nas instituições de ensino e pesquisa, nos movimentos sociais e organizações da sociedade civil, buscando fazer com que as realidades locais não sejam dadas como acabadas, mas que possam ser confrontadas e buscar a sua transformação.

\section{Referências}

BORBA, Amandia Maria de. Identidade em construção: investigando professores na prática da avaliação escolar. São Paulo: EDUC, 2001.

BRASIL. Programa Nacional de Acesso ao Ensino técnico e Emprego. Lei no 12.513, de 26 de outubro de 2011. Disponível em: http://PRONATECportal.mec.gov.br/arquivos/lei_12513.pdf. Acesso em: 10 dez. 2014.

. Lei n. ${ }^{\circ} 12.816$, de 5 de junho de 2013. Altera as Leis n. ${ }^{\circ} 12.513$, de 26 de outubro de 2011, para ampliar o rol de beneficiários e ofertantes da Bolsa-Formação Estudante, no âmbito do Programa Nacional de Acesso ao 
Ensino Técnico e Emprego - PRONATEC.2013a. Disponívelem: http:// www.planalto.gov.br/ccivil_03/_ato2011-2014/2013/Lei/L12816. htm. Acesso em: 12 dez. 2014.

. Portaria n. 1.568, de 3 de novembro de 2011. Dispóe sobre a aprovação do Guia Pronatec de Cursos de Formação Inicial e Continuada, elaborado pela Secretaria de Educação Profissional e Tecnológica do Ministério da Educação, disponibilizado no sítio eletrônico oficial do Ministério da Educação. Disponível em: http://pronatec.mec.gov.br/images/ stories/pdf/portaria_1568.pdf. Acesso em: 14 dez. 2014.

- "Programa Nacional de Acesso ao Ensino Técnico e Emprego PRONATEC”. Guia Pronatec de Cursos FIC. 3 ed. 2013 b.

DEGGERONE, Zenicleia Angelita et al. "Juventude e educação do campo". In Seminário Internacional de Educação do Campo: educação, memória e resistência popular na formação social da América Latina, pp. 1.499-508, Santa Maria, 2014.

EA - Entrevistado A: depoimento [12 dez. 2014, p. 1]. Entrevistadora: Zenicleia A. Deggerone. Aratiba (RS): s.e., 2014. Gravação máquina digital. Entrevista concedida a Zenicleia A. Deggerone.

EB - Entrevistado B: depoimento [13 dez. 2014, p. 1]. Entrevistadora: Zenicleia A. Deggerone. Aratiba (RS): s.e., 2014. Gravação máquina digital. Entrevista concedida a Zenicleia A. Deggerone.

ED - Entrevistado D: depoimento [15 dez. 2014, p. 1]. Entrevistadora: Zenicleia A. Deggerone. Aratiba (RS): s.e., 2014. Gravação máquina digital. Entrevista concedida a Zenicleia A. Deggerone.

EE - Entrevistado E: depoimento [16 dez. 2014, p. 1]. Entrevistadora: Zenicleia A. Deggerone. Aratiba (RS): s.e., 2014. Gravação máquina digital. Entrevista concedida a Zenicleia A. Deggerone.

FONSECA, João José Saraiva da. Metodologia da pesquisa cientifica. Fortaleza: UEC, 2002.

FREIRE, Paulo. Pedagogia da autonomia: saberes necessários à prática educativa. 15 ed. São Paulo: Paz e Terra, 2000.

FRIGOTTO, Gaudêncio et al. "A política de educação profissional no governo Lula: um percurso histórico controvertido”. Educação \& Sociedade, v. 26, n. 92, pp. 1.087-113, Campinas, 2005. 
GIL, Antonio Carlos. Metodologia do ensino superior. São Paulo: Atlas, 1994. IFRS - INSTITUTO FEDERAL DE CIÊNCIA E TECNOLOGIA RIO GRANDE DO SUL. "Projeto Pedagógico do Curso de Agricultor Familiar”. Erechim, 2013a.

. "Relatório semestral Cursos Pronatec -Curso FIC - Agricultor Familiar”. Erechim, 2013b.

. INSTITUTO FEDERAL DE CIÊNCIA E TECNOLOGIA RIO GRANDE DO SUL. "Projeto Pedagógico do Curso de Bovinocultor de Leite”. Erechim, 2014a.

. "Relatório Semestral Cursos Pronatec - Curso FIC - Agricultor Familiar”. Erechim, 2014b.

. "Relatório Semestral Cursos Pronatec - Curso FIC - Bovinocultor de Leite”. Erechim, 2014c.

MARX, Karl. O capital: crítica da economia política. 16 ed. Rio de Janeiro: Civilização Brasileira, 1998, livro 1, v. 1 e 2.

MASETTO, Marcos T. Didática: a aula como centro. São Paulo: FTD, 1997.

MDA - Ministério do Desenvolvimento Agrário. Conferência Nacional de ATER. Brasília, 2012.

OLIVEIRA, Ariovaldo Umbelino de. "Agricultura brasileira: transformações recentes”. In ROSS, Jurandyr Luciano Sanches (org.). Geografia do Brasil. São Paulo: EdUSP, 1996.

RIBEIRO, Marlene. "Política educacional para populações camponesas: da aparência à essência”. Revista Brasileira de Educação, v. 18, n. 54, pp. 669796, Rio de Janeiro, jul.-set. 2013.

RODRIGUES, Otávia. "A relação entre trabalho e conhecimento camponês”. Cadernos CEDES, pp. 50-6, São Paulo, , 1984.

SEMINOTTI, Jonas José. A dinâmica sociopolitica na agricultura familiar: os agricultores familiares e a representação politica do Sutraf no Alto Uruguai gaúcho. Passo Fundo: Editora UPF, 2014. 


\section{Pedagogia da alternância}

\section{Educador/monitor e práticas pedagógicas}

Cíntia Moralles Camillo

Liziany Müller Medeiros

\section{Introdução}

A Educação é um direito de todo e qualquer indivíduo e deve ser garantida pelo poder público a toda a população, independentemente de residir na zona urbana ou rural. É direito garantido por lei que todas as famílias do campo tenham acesso à educação pública e gratuita em todos os níveis de ensino. Segundo Oliveira (2004), construir reflexões acerca do campo, seus sujeitos e, mais precisamente, sobre a Educação do Campo significa que estamos inseridos no debate político, ideológico e teórico. O acesso à escola foi democratizado, mas o acesso aos conhecimentos por ela construídos ainda é restrito, principalmente para o jovem do campo.

Desta forma, e para uma melhor compreensão do problema, parte-se para a análise de uma importante categoria espacial: o lugar. É por meio da compreensão e do conhecimento do lugar, que os educadores das escolas do campo poderão compor suas práticas educativas, de forma a respeitar e apreender sobre os saberes sociais das comunidades envolvidas (Moura, 2009, p. 13).

Para que as escolas atendam às peculiaridades dos sujeitos do campo, é necessário que o educador leve em conta a vida e o cotidiano dos educandos, entendendo a realidade, o contexto social e as dificuldades por eles enfrentados. Conforme Vieira Filho e Fishlow (2013), as pequenas propriedades são 
desprovidas de máquinas agrícolas, ordenha mecânica e insumos agrícolas, muitas vezes até de suporte técnico de um profissional.

\begin{abstract}
A Educação do Campo nasceu como mobilização/pressão de movimentos sociais por uma política educacional para comunidades camponesas: nasceu da combinação das lutas dos Sem Terra pela implantação de escolas públicas nas áreas de Reforma Agrária com as lutas de resistência de inúmeras organizações e comunidades camponesas para não perder suas escolas, suas experiências de educação, suas comunidades, seu território, sua identidade (Caldart, 2000).
\end{abstract}

A escola do campo tem como objetivo profissionalizar e dar condições aos sujeitos em manter-se no campo, preparando-os para isso. Percebe-se, cada vez mais, a importância em não formar os educandos apenas para os sistemas produtivos, mas como cidadãos comprometidos com a problemática referente à modernização da agricultura e consequente crise social, ambiental e econômica (Lourenzi et al., 2012).

Este capítulo tem o objetivo de problematizar as influências que o educador/monitor e as práticas pedagógicas exercem no desenvolvimento da Pedagogia da Alternância, por meio de uma revisão sistemática das publicações acadêmicas sobre o tema no período de 2007 a 2017.

\title{
Origem da Pedagogia da Alternância
}

A Pedagogia da Alternância teve o início na França, em 1935, com a criação da primeira Maison Familiale Rurale (MFR), que tinha como missão atender às famílias moradoras do campo, especialmente os jovens do sexo masculino (Detogni e Zancanella, 2016). A Alternância chegou ao Brasil a partir de 1969, com as primeiras Escolas Famílias Agrícolas (EFAs), no estado do Espírito Santo; já as Casas Familiares Rurais (CFRs) tiveram o seu início no nordeste do país, em 1987, em Alagoas. No ano de 2016, a União Nacional das Escolas Famílias Agrícolas do Brasil (UNEFAB) publicou dados gerais relevantes a respeito das EFAs no país, conforme a tabela 1. 
Tabela 1: Dados sobre as Escolas Famílias Agrícolas (EFAs) no Brasil

\begin{tabular}{|l|c|}
\hline Total de EFAs em funcionamento & 112 \\
\hline Total de EFAs em implantação & 40 \\
\hline Número de cursos no Ensino Fundamental & 103 \\
\hline Número de cursos no Ensino Médio Profissionalizante & 21 \\
\hline Número de alunos atendidos pelas EFAs & 10.779 \\
\hline Número de comunidades rurais envolvidas & 2.818 \\
\hline Número de famílias envolvidas & 25.400 \\
\hline Número de educadores que trabalham nas EFAs & 624 \\
\hline Outras pessoas (auxiliares/colaboradores) & 250 \\
\hline
\end{tabular}

Fonte: União Nacional das Escolas Famílias Agrícolas do Brasil (UNEFAB), 2016.

Atualmente, a localização predominante das CFRs está na região Sul do país, e, de acordo com dados da Associação Regional das Casas Familiares Rurais do Sul do Brasil (Arcarfa Sul) (2014), existem, na referida região, 71 Casas Familiares Rurais, sendo 41 no Paraná, 22 em Santa Catarina e 8 no Rio Grande do Sul. Essas casas vêm oferecendo e possibilitando a muitos jovens do meio rural uma formação voltada a sua realidade, com o objetivo integral de promover o seu desenvolvimento socioprofissional (Bernardi et al., 2014).

Segundo Monteiro (2014), a Pedagogia da Alternância tem como principal característica o envolvimento da comunidade e da família no processo educativo e possui a intencionalidade em proporcionar uma formação profissional técnica para que o indivíduo possa atuar no meio em que vive. Ainda, apresenta a finalidade de abrir caminhos que proporcionam ao agricultor, à sua família e à comunidade em geral o desenvolvimento e a criação de novas alternativas de produção e conhecimento, a fim de garantir trabalho, renda na propriedade, além do convívio em sociedade (Gimonet, 2007).

"A alternância constitui o meio, ao mesmo tempo para aceder a uma qualificação reconhecida por diploma e de construir uma identidade profissional duradora" (Gimonet, 2007, p. 119). Contudo, para garantir o processo educativo numa proposta interativa, a alternância desenvolve-se em três momentos e espaços significativos, conforme a figura 1 . 
Figura 1: 0 método de Alternância

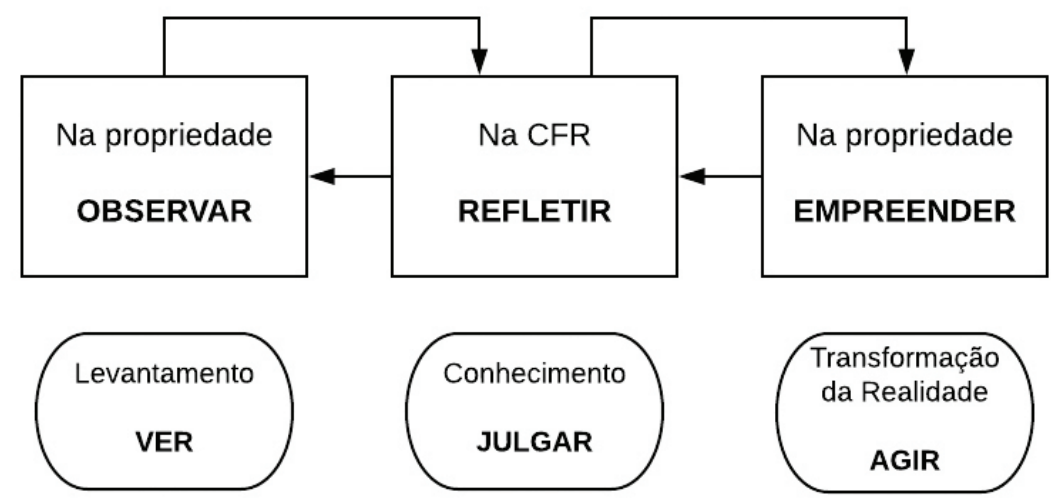

Fonte: Samua, 2012, p. 43.

Portanto, o processo de desenvolvimento na Pedagogia da Alternância, os saberes teóricos e práticos construídos a partir da relação propriedade- CFR -propriedade, com a participação do educando do campo, são de suma importância para garantir uma proposta interativa e dinâmica, possibilitando que o conhecimento gerado rompa barreiras da escola e chegue à comunidade do campo. O processo de ensino-aprendizagem proposto por essa Pedagogia "possibilita aos educandos vivenciarem momentos na escola, na família e na comunidade. A aquisição do conhecimento se dá de forma construtiva e participativa, envolvendo vários autores: educandos, pais e monitores/educadores" (Queiroz et al., 2006, p. 60).

A Pedagogia da Alternância abre caminhos, proporciona ao jovem do campo a obtenção de sua formação, alternando os períodos de estudos na CFR ou nas EFAs, assim como na sua propriedade, a partir da relação entre a teoria e a prática. Também auxilia o educando no conhecimento e valorização de sua cultura e o conduz para o despertar da consciência crítica, visando à ampliação e ao enriquecimento do seu modo de vida (Jesus, 2011). 


\section{Práticas pedagógicas na Pedagogia da Alternância}

O processo de ensino-aprendizagem diferenciado torna-se possível devido ao conjunto de ferramentas, metodologias e práticas pedagógicas. As ferramentas pedagógicas são apontadas por Gimonet (2007) como possibilidades para articular o tempo e o espaço da formação do educando, associar a formação profissional com a formação geral e associar os pais, jovens e educadores/monitores ao processo de formação, acompanhando cada jovem nas suas aprendizagens e caminhadas. A seguir, destacam-se as seguintes práticas metodológicas mediante os pressupostos de Moro (2016).

Plano de Estudo: elemento chave da Pedagogia da Alternância, pois os demais elementos pedagógicos se originarão das temáticas abordadas, a partir dos planos de estudos aplicados em cada ano. Integra a relação entre a escola, a família e o meio em que vive o educando, gerando uma abordagem de saberes empíricos;

Colocação em Comum: é a socialização das questões abordadas no plano de estudo, na qual todo educando tem contato com diferentes realidades, promovendo a troca de experiências. É a base para o educador trabalhar suas disciplinas, sendo que, após uma reflexão, o educando retorna ao meio com um novo olhar sobre a própria realidade;

Caderno da Realidade: é o caderno da vida do educando, no qual ele registra suas reflexôes sobre as vivências escolares, familiares e comunitárias. Estarão arquivadas as sínteses, redações ilustradas e respostas dos planos de estudos bem como os relatórios de visitas de estudos e experiências;

Folha de Observação: é uma complementação ao plano de estudo, principalmente para atender levantadas mais polêmicas, necessitando de um aprofundamento maior e uma nova pesquisa com base na realidade dos educandos;

Cursos e Palestras: são atividades mais práticas realizadas a partir dos temas dos planos de estudos, objetivando construir novas aprendizagens, além dos conteúdos curriculares; 
Visitas e Viagens de Estudo: complementa o plano de estudos e tem por objetivo proporcionar aos educandos novas realidades e saberes que poderão ser utilizados em sua realidade local, a fim de perceber contradições, levantar hipóteses, superar dúvidas, entre outros. Os educandos são encaminhados e assistidos por educadores que orientam e organizam a realização das visitas e viagens de estudo;

Estágio: possibilita ao educando o contato direto com outra realidade além da sua, vivenciando novas práticas e podendo, assim, melhorar as atividades na própria propriedade;

Serões: são espaços e tempo de reflexão, no período noturno, quando geralmente acontecem atividades artísticas, culturais, lazer, entre outras, que em sua maioria são organizadas pelos próprios educandos;

Visitas às Famílias: possibilita ao educador conhecer a realidade dos educandos e troca de experiências em que a escola e a família têm uma aproximação maior, o que favorece o processo de ensino-aprendizagem do educando;

Caderno de Acompanhamento: é um elemento de ligação entre escola e família, no qual a escola fica ciente das atividades dos educandos no meio sociofamiliar comunitário e a família ficam a par das atividades dos educandos no meio escolar;

Projeto Profissional do Jovem: o educando escolhe um tema do próprio interesse profissional, realiza uma pesquisa teórica e o aplica em sua propriedade, considerando as técnicas exigidas, conforme sua escolha. Desenvolve-se ao final do ensino médio profissionalizante;

Atividade de Retorno: o educando realiza atividades concretas em sua comunidade a partir de temas trabalhados nos planos de estudo. Em seguida, volta para a escola e socializa a experiência;

Avaliações: o processo de avaliação na perspectiva da Alternância é dinâmico e participativo, envolve o educando, a escola, a família e a comunidade, em uma interação contínua e dinâmica. Nesse contexto, a Pedagogia de Alternância constitui-se de um método pedagógico inovador e próprio para atender ao público alternante, vindo a permear o desenvolvimento cognitivo do educando. 


\section{0 papel do educador/monitor na Pedagogia da Alternância}

O papel do educador/monitor na Pedagogia da Alternância está muito além da sala de aula. Assim, a docência constitui-se em um âmbito de maior abrangência, uma vez que, nessa perspectiva, o educando fica em sistema de internato na escola e requer uma metodologia específica aplicada dentro e fora da instituição, utilizando as ferramentas e as práticas pedagógicas já mencionadas anteriormente (Krüger, 2016). Ao educador/monitor é possibilitado que abranja todos os conteúdos interdisciplinares, a partir das questões vivenciadas pelos educandos por meio do plano de estudo. Desse modo:

O monitor, mais que um educador que trabalha num ou para um Centro Educativo, é alguém que, através do seu trabalho específico de educador, se associa a responsabilidade de quem digere e acompanha um Projeto. Tudo isto nos permite falar de um Projeto Educativo e de promoção do território, protagonizado por seus sujeitos, que devem conhecer profundamente. Ser monitor requer umas aptidões para o conhecimento (reconhecimento) do meio e de seus atores (García-Marirrodriga e PuigCalvó, 2010, p. 76).

Assim, pode-se refletir que o papel do educador/monitor não é apenas ser o responsável por uma disciplina, mas construir um trabalho coletivo e interdisciplinar, abrangendo a família e a sociedade nas quais o educando está inserido. Outras funções são atribuídas aos educadores/monitores: a responsabilidade pela organização, dinamização e elaboração das atividades docentes e do Plano de Formação, sempre respeitando o calendário agrícola (Rosa e Vendrusculo, 2013).

Para Aued e Vendramini (2009), o conceito de professor/monitor não é apenas de um profissional que detém conhecimentos, mas também aquele que acompanha, guia, orienta, intervindo sempre que necessário. Conforme Lorenzini (2006), "ser monitor é muito mais que exercer uma função, é viver dentro de uma complexidade, é acompanhar o desenvolvimento do educando, ser o seu guia, seu orientador, o facilitador no aprendizado, é dar a direção para que o educando construa o seu conhecimento".

$\mathrm{Na}$ formação do monitor/educador, é essencial que seja realizado um estágio de vivência em uma das CFRs, com ao menos uma alternância, a fim de conhecer as práticas pedagógicas da referida perspectiva (Rosa e Vendrusculo, 2013). Ainda, segundos os autores, para ser monitor/educador, é essencial 
que seja feito um curso de formação de monitor para trabalhar com os pilares das Casas Familiares Rurais, a Associação, a Pedagogia da Alternância, a formação integral do jovem e família e o desenvolvimento do meio.

Conforme os pressupostos de Gimonet (2007), os educadores/monitores precisam ser qualificados e organizados para trabalhar com a Pedagogia da Alternância e, por consequência, ter um trabalho seguro e estável para exercer sua profissão de maneira duradoura. Tendo em vista que a formação dos educadores/monitores nas universidades é pouco explorada, as Associações das Casas Familiares Rurais Regionais acabam por promover a formação dos monitores anualmente, com trocas de experiências e conhecimentos (Rosa e Vendrusculo, 2013).

\section{Desenvolvimento}

Este capítulo é resultado de uma pesquisa que consiste em uma revisão sistemática, com base nos estudos sobre como a avaliação do educador/monitor e das práticas pedagógicas influenciam no desenvolvimento da Pedagogia da Alternância. Para Linde e Willich (2003), a revisão sistemática é uma forma de pesquisa que se baseia na literatura como fonte de dados, sendo considerada capaz de apresentar resultados conflitantes e/ou coincidentes, proporcionando base para investigações futuras.

Para obter os artigos analisados, utilizaram-se os descritores "Educação do Campo", "Pedagogia da Alternância", "Educação Rural", "Escola do Campo", "Escola Agrícola" e "Escola Rural" na base de dados da Scientific Electronic Library Online (SciELO) e do Portal de Periódicos da Coordenação de Aperfeiçoamento de Pessoal de Nível Superior do Ministério da Educação e Cultura (Capes/MEC). O período de pesquisa incluiu artigos publicados entre 2007 a 2017.

A inclusão ou exclusão dos artigos definiu-se, num primeiro instante, pela análise dos títulos, resumos e palavras-chave dos estudos publicados nos portais. Logo após, realizou-se a leitura na íntegra dos estudos pré-selecionados para definir se a publicação se enquadrava ou não no presente estudo.

É importante observar que a produção científica sobre Pedagogia da Alternância e Educação do Campo, relacionadas à metodologias de ensino, são pouco exploradas. Foram encontrados no total 19 artigos na base de dados SciELO, dos quais dois se encaixaram nos critérios de inclusão e foram se- 
lecionados para a análise. $\mathrm{Na}$ base de dados da Capes, foram encontrados 24 artigos, mas somente 9 se encaixavam nos critérios propostos.

No quadro 2, são apresentados os autores, ano de publicação e títulos dos artigos selecionados, que foram realizados no período de 2007 a 2017, os locais das pesquisas e os nomes dos periódicos nos quais os referidos artigos foram publicados.

Durante a realização do estudo, ASSUNÇÃO, C.; BORGES, R. (2012) perceberam que os habitantes da Ilha de Caratateua, no distrito de Outeiro, município de Belém do Pará, vivem basicamente da pesca, da agricultura e de pequeno comércio local, enfrentando particularidades socioculturais relevantes.

Quadro 2: Artigos selecionados no período de 2007 a 2017

\begin{tabular}{|l|c|c|c|}
\hline Autor/Ano & Local & Periódico & Título \\
\hline $\begin{array}{l}\text { Assunção e } \\
\text { Guerra, 2011 }\end{array}$ & $\begin{array}{c}\text { Escola Casa da Pesca } \\
\text { (CEPE), localizada } \\
\text { na Ilha de Cara- } \\
\text { tateua, distrito de } \\
\text { Outeiro, município } \\
\text { de Belém-PA }\end{array}$ & $\begin{array}{c}\text { Revista Latinoa- } \\
\text { mericana de Etno- } \\
\text { matemática }\end{array}$ & $\begin{array}{c}\text { Etnomatemática e pedago- } \\
\text { gia da alternância: elo entre } \\
\text { saber matemático e práticas } \\
\text { sociais }\end{array}$ \\
\hline $\begin{array}{l}\text { Bernardi et } \\
\text { al., 2014 }\end{array}$ & $\begin{array}{c}\text { Casa Familiar Rural } \\
\text { Santo Agostinho, } \\
\text { Quilombo, Santa } \\
\text { Catarina }\end{array}$ & Reflexáo e Ação & $\begin{array}{c}\text { O desafio de ser professor } \\
\text { na escola do campo: o } \\
\text { contexto da Casa Familiar } \\
\text { Rural Santo Agostinho }\end{array}$ \\
\hline Castro, 2011 & $\begin{array}{c}\text { Casa Familiar de } \\
\text { Altamira/Pará }\end{array}$ & $\begin{array}{c}\text { Monografia da } \\
\text { Faculdade de } \\
\text { Engenharia Agro- } \\
\text { nômica da UFPA }\end{array}$ & $\begin{array}{c}\text { O papel da Casa Família } \\
\text { Rural de Altamira na for- } \\
\text { maçáo técnica de jovens do } \\
\text { campo }\end{array}$ \\
\hline $\begin{array}{l}\text { Conceição e } \\
\text { Rodrigues, } \\
2012\end{array}$ & $\begin{array}{c}\text { Escola Familiar } \\
\text { Agrícola Rio Peixe, } \\
\text { município de Balsas, } \\
\text { Sul do Maranhão }\end{array}$ & Geosaberes & $\begin{array}{c}\text { Caminhos da sustentabi- } \\
\text { lidade: análise preliminar } \\
\text { das práticas pedagógicas e } \\
\text { o ensino aprendizagem dos } \\
\text { alunos na Escola Família } \\
\text { Agrícola Rio Peixe - Balsa/ } \\
\text { MA }\end{array}$ \\
\hline
\end{tabular}




\begin{tabular}{|c|c|c|c|}
\hline $\begin{array}{l}\text { Detogni e } \\
\text { Zancanella, } \\
2016\end{array}$ & $\begin{array}{l}\text { Casa Familiar Rural } \\
\text { de Coronel Vivida } \\
\text {-Paraná }\end{array}$ & $\begin{array}{l}\text { Revista Brasileira } \\
\text { de Educação do } \\
\text { Campo }\end{array}$ & $\begin{array}{l}\text { Casa Familiar Rural de Co- } \\
\text { ronel Vivida-PR: desafios } \\
\text { da formação continuada } \\
\text { em Pedagogia da Alter- } \\
\text { nância }\end{array}$ \\
\hline Klein, 2016 & $\begin{array}{l}\text { Casa Familiar Rural } \\
\text { de São José do Ce- } \\
\text { dro, Santa Catarina }\end{array}$ & Pedagógica & $\begin{array}{l}\text { A questão do gênero e a } \\
\text { Pedagogia da Alternância } \\
\text { na Casa Familiar Rural de } \\
\text { São José do Cedro (SC) }\end{array}$ \\
\hline $\begin{array}{l}\text { Oliveira, } \\
2013\end{array}$ & $\begin{array}{l}\text { Escola Família Agrí- } \\
\text { cola Dom Fragoso, } \\
\text { localizada no mu- } \\
\text { nicípio de Indepen- } \\
\text { dência, Ceará }\end{array}$ & Mercator & $\begin{array}{c}\text { A Escola Camponesa na } \\
\text { Alternância e o ensino de } \\
\text { Geografia }\end{array}$ \\
\hline $\begin{array}{l}\text { Portugal et } \\
\text { al., } 2016\end{array}$ & $\begin{array}{c}\text { Casa Familiar Rural, } \\
\text { Altamira, Pará }\end{array}$ & $\begin{array}{c}\text { Revista de Educa- } \\
\text { ção em Ciências e } \\
\text { Matemática }\end{array}$ & $\begin{array}{l}\text { A Biologia na Pedagogia da } \\
\text { Alternância: perspectivas } \\
\text { e desafios de uma ciência } \\
\text { natural integrada a Casa } \\
\text { Familiar Rural de Altami- } \\
\text { ra-Pará }\end{array}$ \\
\hline $\begin{array}{l}\text { Silva e Nery, } \\
2016\end{array}$ & $\begin{array}{c}\text { Escola Família } \\
\text { Agrícola do Pacuí/ } \\
\text { Amapá }\end{array}$ & $\begin{array}{l}\text { Eventos Pedagó- } \\
\text { gicos }\end{array}$ & $\begin{array}{l}\text { Pedagogia da Alternância } \\
\text { no Amapá: } \\
\text { Um estudo na Escola Fa- } \\
\text { mília Agrícola do Pacuí }\end{array}$ \\
\hline $\begin{array}{l}\text { Silveira e } \\
\text { Peripolli, } \\
2016\end{array}$ & $\begin{array}{l}\text { Escola do Campo } \\
\text { Municipal São } \\
\text { Manuel, distrito } \\
\text { Colorado do Norte } \\
\text { - Nova Canaã do } \\
\text { Norte/MT }\end{array}$ & $\begin{array}{l}\text { Eventos Pedagó- } \\
\text { gicos }\end{array}$ & $\begin{array}{l}\text { O currículo e suas inquie- } \\
\text { taçóes no campo: uma } \\
\text { análise da proposta curri- } \\
\text { cular da Escola Municipal } \\
\text { São Manuel em Colorado } \\
\text { do Norte - Mato Grosso }\end{array}$ \\
\hline $\begin{array}{l}\text { Teodoro et } \\
\text { al., } 2008\end{array}$ & $\begin{array}{l}\text { Escola Família } \\
\text { Agroindustrial de } \\
\text { Turmalina, Vale do } \\
\text { Jequitinhonha, mu- } \\
\text { nicípio de Turmali- } \\
\text { na, Minas Gerais }\end{array}$ & $\begin{array}{l}\text { Sociedade Brasi- } \\
\text { leira de Economia, } \\
\text { Administração e } \\
\text { Sociologia Rural }\end{array}$ & $\begin{array}{l}\text { A pedagogia da alternância } \\
\text { na construçáo do desen- } \\
\text { volvimento rural do Vale } \\
\text { do Jequitinhonha, Minas } \\
\text { Gerais }\end{array}$ \\
\hline
\end{tabular}

Fonte: Dados da própria pesquisa, 2017.

Mesmo diante de fatores impeditivos, como as longas distâncias entre as suas casas e a escola, jovens com idades entre 15 e 24 anos não abandonam os estudos, tendo em vista que muitos deles moram ao redor da ilha ou no seu interior. 
Perante o exposto, os educandos necessitam de uma metodologia pedagógica diferenciada das escolas localizadas em espaços urbanos, sendo necessários cursos de formação continuada para os educadores/monitores. Por tal motivo, os autores defendem que a educação do campo precisa ser uma educação diferenciada e específica, isto é, alternativa. Logo, a Escola Casa da Pesca tem como prática pedagógica contar com as experiências dos educandos sobre o processo da pesca, permitindo a reciprocidade de ideias e experiências entre os sujeitos, promovendo também a pesquisa de campo, visitas técnicas, aulas práticas em indústrias, projetos e estágios.

O estudo de Bernardi et al. (2014) na Casa Família Rural Santo Augustinho analisou que os educadores/monitores se mostram comprometidos com formação integral do educando e com os pressupostos emancipatórios das lutas do campo. Entretanto, há necessidade de se desenvolverem como agentes mediadores da aprendizagem, devido ao protagonismo necessário para a aprendizagem dos educandos, exigindo interação e atitude de colaboração. Por fim, os autores acreditam que mesmo os educadores engajados no ensino aprendizagem, com metodologias como o plano de formação, de estudos, caderno de realidade e projetos, necessitam de cursos de formação continuada para poderem dar continuidade na prática educativa.

Os resultados da pesquisa de Castro (2011) evidenciam que a Casa Família de Altamira tem contribuído positivamente na formação profissional de seus educandos, refletindo significativamente na adoção de inovações técnicas nas propriedades; em alguns casos, influenciando diretamente na dinamização econômica das famílias, assim como na melhoria da qualidade de vida. Verificando-se que os estudantes colocam em prática o que aprendem em projetos, de acordo com os educandos entrevistados, seria necessária a realização de mais visitas dos monitores para acompanhamento dos educandos durante o espaço comunidade, a fim de conhecerem melhor as potencialidades e limitações de cada estabelecimento agrícola. Em relação aos monitores da Casa Familiar, estes encontram dificuldades para desenvolver atividades como a interdisciplinaridade, acreditando que poderia ser amenizado se houvesse uma formação pedagógica continuada.

Os autores Conceição e Rodrigues (2012) verificaram que a construção de novos conteúdos a partir da problematização da vida dos educandos, pelas práticas nas propriedades, na família e nos serões de estudo, é um conjunto de práticas metodológicas que vêm proporcionando conhecimentos, inclusive sobre sustentabilidade. No estudo foi possível verificar que os pais, os edu- 
candos e educadores/monitores estão satisfeitos com a metodologia de ensino da Casa Familiar, na qual se verificou que 100\% dos estudantes colocaram em prática alguma experiência ou projeto desenvolvido.

Detogni e Zancanella (2016), em sua pesquisa na Casa Familiar Rural de Coronel Vivida - Paraná, analisaram que os educadores/monitores não tinham experiências com a educação do campo e que a rotatividade destes é muito grande; constataram que um dos principais motivos pode ser a falta de incentivos e recursos financeiros. Além disso, apontam desmotivação e acreditam que a falta de capacitação específica influencia no resultado final. $\mathrm{Na}$ pesquisa, foi constatado que nenhum dos educadores e monitores possuem formação para a Pedagogia de Alternância. Logo, em relação às práticas pedagógicas, esses educadores/monitores utilizam somente o acompanhamento das atividades práticas de campo.

Klein (2012), em sua pesquisa, acredita que se deve pensar na qualificação dos educadores/monitores em uma educação voltada para a Pedagogia da Alternância com políticas públicas bem estruturadas, na qual o olhar seja voltado para a educação do campo. A autora observou que as educandas estão em menor número se comparado aos educandos. Em relação aos educadores, estes acreditam que é preciso desmitificar a participação da mulher nas escolas, uma vez que é um lugar sem preconceitos em que se formam cidadãos. São educadores engajados por uma educação democrática e qualificada, procurando sempre cumprir da melhor forma a metodologia da alternância, por meio do Caderno da Realidade e do Acompanhamento de Práticas do Campo.

Durante seu estudo na Escola Família Agrícola Dom Fragoso, Oliveira (2013) pôde verificar que a escola é bem estruturada e organizada, proporcionando ao educando toda educação e apoio necessários. A escola oferece metodologias específicas para desenvolver o seu plano de formação, tais como: Caderno de Realidade, Visita de Estudos, Intervenção Externa, Visita às Famílias, Estágios e Projeto Profissional. A instituição ainda segue a pedagogia freireana, na qual os Planos de Estudos estão inseridos.

Segundo Portugal et al. (2016), a Pedagogia da Alternância possibilita a experiência de um estudo de biologia aliado à interdisciplinaridade e significativo à realidade dos estudantes alternantes. Os autores identificaram que a metodologia por meio de atividades investigativas proporciona ao educando uma maior participação, averiguação e solução de problemas. Dos desafios, os autores destacam a importância de promover espaços de formação docente, cursos de capacitação e laboratórios de pesquisas nas escolas. 
Silva e Nery (2016) evidenciaram que a falta de recursos financeiros na Escola Família Agrícola do Pacuí impede a efetivação dos instrumentos de aprendizagem, voltada para atingir o desenvolvimento local, que se realiza por meio da formação dos jovens. Os próprios educandos são os atores de sua formação, destacando-se a cooperação educativa. Educadores/monitores desmotivados e em número muito pequeno fazem o seu melhor pelos educandos, utilizando Caderno de Realidade, Visita nas Propriedades, Planos de Estudo e Avaliações.

No quadro 3, são apresentados os principais cursos oferecidos, o total de educandos matriculados nas escolas, os níveis de ensino, os períodos de alternância, o nível de capacitação do educador/monitor (analisado como requer e não requer) e as práticas pedagógicas.

Quadro 3: Principais características dos artigos pesquisados

\begin{tabular}{|c|c|c|c|c|}
\hline \multirow[b]{2}{*}{ Autor/ano } & \multirow[b]{2}{*}{$\begin{array}{l}\text { Curso oferecido/ } \\
\text { total de alunos } \\
\text { matriculados }\end{array}$} & \multirow[b]{2}{*}{$\begin{array}{l}\text { Níveis de en- } \\
\text { sino/períodos }\end{array}$} & \multicolumn{2}{|c|}{ Variáveis } \\
\hline & & & $\begin{array}{c}\text { Nível de } \\
\text { capacitaçáo } \\
\text { educador/ } \\
\text { monitor }\end{array}$ & $\begin{array}{l}\text { Práticas pedagó- } \\
\text { gicas }\end{array}$ \\
\hline $\begin{array}{l}\text { Assunção } \\
\text { e Guerra, } \\
2011\end{array}$ & $\begin{array}{l}\text { Qualificação pro- } \\
\text { fissional de for- } \\
\text { mação inicial em } \\
\text { pesca e aquicultu- } \\
\text { ra/90 alunos }\end{array}$ & $\begin{array}{l}\text { Fundamental } \\
\text { e EJA/15 dias } \\
\text { de alternância }\end{array}$ & Requer & $\begin{array}{l}\text { Pesquisa de Campo, } \\
\text { Visitas Técnicas, } \\
\text { Aulas Práticas em } \\
\text { Industrias, Projetos } \\
\text { e Estágios }\end{array}$ \\
\hline $\begin{array}{l}\text { Bernardi et } \\
\text { al., } 2014\end{array}$ & $\begin{array}{c}\text { Curso Profissiona- } \\
\text { lizante Técnico em } \\
\text { Agronegócios/61 } \\
\text { alunos }\end{array}$ & $\begin{array}{c}\text { Fundamental } \\
\text { e Médio/15 } \\
\text { dias de alter- } \\
\text { nância }\end{array}$ & Requer & $\begin{array}{c}\text { Plano de Formação, } \\
\text { Plano de Estudos, } \\
\text { Caderno de Reali- } \\
\text { dade e Projetos }\end{array}$ \\
\hline $\begin{array}{c}\text { Castro, } \\
2011\end{array}$ & $\begin{array}{l}\text { Técnico Agríco- } \\
\text { la/17 alunos }\end{array}$ & $\begin{array}{l}\text { Fundamen- } \\
\text { tal/15 dias de } \\
\text { alternância }\end{array}$ & Requer & $\begin{array}{l}\text { Plano de Estudo, } \\
\text { Plano de Formaçáo, } \\
\text { Caderno de Acom- } \\
\text { panhamento, Colo- } \\
\text { cação em Comum, } \\
\text { Cursos, Visitas de } \\
\text { Estudos, Caderno } \\
\text { Pedagógico, Avalia- } \\
\text { çôes e Projetos }\end{array}$ \\
\hline
\end{tabular}




\begin{tabular}{|c|c|c|c|c|}
\hline $\begin{array}{l}\text { Conceição } \\
\text { e Rodri- } \\
\text { gues, } 2012\end{array}$ & $\begin{array}{c}\text { Fundamental } \\
\text { de Habilidades } \\
\text { Agropecuárias } / 55 \\
\text { alunos }\end{array}$ & $\begin{array}{l}\text { Fundamen- } \\
\text { tal/15 dias de } \\
\text { alternância }\end{array}$ & Não Requer & $\begin{array}{l}\text { Serão de Estudos, } \\
\text { Práticas na proprie- } \\
\text { dade e Práticas na } \\
\text { família }\end{array}$ \\
\hline $\begin{array}{c}\text { Detogni e } \\
\text { Zancanella, } \\
2016\end{array}$ & $\begin{array}{l}\text { Técnico em Ali- } \\
\text { mentos/48 alunos }\end{array}$ & $\begin{array}{l}\text { Ensino Mé- } \\
\text { dio/1 semana } \\
\text { com a família } \\
\text { e } 1 \text { semana na } \\
\text { Escola }\end{array}$ & Requer & $\begin{array}{c}\text { Acompanhamento } \\
\text { das Atividades Práti- } \\
\text { cas de Campo }\end{array}$ \\
\hline $\begin{array}{l}\text { Klein, } \\
2012\end{array}$ & $\begin{array}{l}\text { Curso Multidisci- } \\
\text { plinar/250 alunos }\end{array}$ & $\begin{array}{l}\text { Ensino Mé- } \\
\text { dio/Intercala } \\
1 \text { semana na } \\
\text { Escola e } 2 \\
\text { semanas com } \\
\text { a família }\end{array}$ & Requer & $\begin{array}{l}\text { Caderno de Reali- } \\
\text { dade e Acompanha- } \\
\text { mento de Práticas } \\
\text { de Campo }\end{array}$ \\
\hline $\begin{array}{l}\text { Oliveira, } \\
2013\end{array}$ & $\begin{array}{l}\text { Curso Técnico } \\
\text { de Nível Médio } \\
\text { Integrado com } \\
\text { Habilitação em } \\
\text { Agropecuária/74 } \\
\text { alunos }\end{array}$ & $\begin{array}{l}\text { Médio } 15 \text { dias } \\
\text { de alternância }\end{array}$ & Não requer & $\begin{array}{l}\text { Caderno de Reali- } \\
\text { dade, Visita de Es- } \\
\text { tudos, Intervençáo } \\
\text { Externa, Visita às } \\
\text { Famílias, Estágios e } \\
\text { Projeto Profissional. }\end{array}$ \\
\hline $\begin{array}{l}\text { Portugal et } \\
\text { al., } 2016\end{array}$ & $\begin{array}{l}\text { Curso de Agricul- } \\
\text { tura/115 alunos }\end{array}$ & $\begin{array}{c}\text { EJA/15 dias } \\
\text { de Alternância }\end{array}$ & Requer & $\begin{array}{c}\text { Atividades Investi- } \\
\text { gativas }\end{array}$ \\
\hline $\begin{array}{c}\text { Silva e } \\
\text { Nery, } 2016\end{array}$ & $\begin{array}{c}\text { Técnico Profis- } \\
\text { sionalizante em } \\
\text { Agropecuária/166 } \\
\text { alunos }\end{array}$ & $\begin{array}{l}\text { Ensino Mé- } \\
\text { dio/ Intercala } \\
1 \text { semana na } \\
\text { Escola e } 2 \\
\text { semanas com } \\
\text { a família }\end{array}$ & Requer & $\begin{array}{l}\text { Caderno de Rea- } \\
\text { lidade, Visitas de } \\
\text { Professores nas Pro- } \\
\text { priedades, Planos de } \\
\text { Estudos e Avaliaçóes }\end{array}$ \\
\hline $\begin{array}{l}\text { Silveira e } \\
\text { Peripolli, } \\
2016\end{array}$ & $\begin{array}{l}\text { Multidiscipli- } \\
\text { nar/250 alunos }\end{array}$ & $\begin{array}{l}\text { Educação } \\
\text { Infantil e } \\
\text { Fundamen- } \\
\text { tal/15 dias de } \\
\text { alternância }\end{array}$ & Requer & $\begin{array}{l}\text { A escola não possui } \\
\text { métodos pedagó- } \\
\text { gicos }\end{array}$ \\
\hline $\begin{array}{l}\text { Teodoro et } \\
\text { al., } 2008\end{array}$ & $\begin{array}{c}\text { Educação Profis- } \\
\text { sional Básica em } \\
\text { Agroindústria/260 } \\
\text { alunos }\end{array}$ & $\begin{array}{c}\text { Fundamental } \\
\text { e Médio/15 } \\
\text { dias de alter- } \\
\text { nância }\end{array}$ & Requer & $\begin{array}{c}\text { Estágios, Seminá- } \\
\text { rios, Reuniōes e } \\
\text { Cursos de Capaci- } \\
\text { tação }\end{array}$ \\
\hline
\end{tabular}

Fonte: Dados da própria pesquisa, 2017.

Na pesquisa realizada por Silveira e Peripolli (2016), os autores verificaram que a proposta curricular implantada na Escola São Manuel é totalmen- 
te urbana, havendo apenas adaptações feitas pelos educadores/monitores. Verificou-se também que há alguns impedimentos, tanto no campo pedagógico quanto no humano, financeiro e político. Contudo, cabe ressaltar que a comunidade busca se adaptar e proporcionar o ensino-aprendizagem para os jovens do local.

Teodoro et al. (2008) salientam que os pais são a base da escola do campo, pois sem o apoio deles os educandos não iriam à escola. No entanto, a Escola Família Agroindustrial de Turmalina está passando por sérios problemas financeiros, o que não contribui para um efetivo quadro de educadores/monitores, havendo muita rotatividade entre eles e sendo difícil, assim, manter e fixar uma metodologia pedagógica.

\section{Considerações finais}

As Escolas do Campo permitem a organização da formação em espaços e tempos diferenciados, contribuindo significativamente com a formação integral do jovem educando, mostrando, assim, que a Pedagogia da Alternância proporciona aprendizagens multidisciplinares, auxilia na construção do conhecimento.

Pode-se verificar que nem todas as escolas utilizam a prática recomendada para a Pedagogia da Alternância e que $83 \%$ apontam a necessidade de cursos de capacitação aos seus educadores/monitores. Inclusive, na sua grande maioria, ainda são educandos de graduação e sem a devida formação para atuar na Pedagogia da Alternância - que requer uma visão muito além da sala de aula -, considerando que têm nos seus currículos uma realidade muito diferente das necessidades do educando do campo. Vai, assim, na direção contrária do que procura construir a Educação do Campo, por meio das licenciaturas em Educação do Campo, que buscam formar educadores sensíveis às questões que permeiam os sujeitos do campo.

Verificou-se também que o educador/monitor sofre com os baixos salários, o que desmotiva e, muitas vezes, faz com que esses profissionais abandonem a Escola do Campo, havendo, assim, uma grande rotatividade. Os fatores elencados afetam automaticamente a metodologia das práticas pedagógicas propostas, especialmente para a Pedagogia da Alternância.

A ação educativa na Pedagogia da Alternância não está vinculada apenas a uma aula expositiva e transferência de conhecimentos, atos que exigem so- 
mente compreensão e memorização, mas, sobretudo, proporciona a mediação de pesquisas de campo e experimentações práticas e colaborativas, considerando a experiência do cotidiano a matéria-prima para uma aprendizagem dinâmica e democrática. Busca-se a construção do conhecimento a partir do conhecimento empírico do meio rural, no qual o educando está inserido; por isso, é necessário que o educador/monitor enxergue essa realidade, que esse profissional tenha a devida qualificação para entender que o educando em questão é um indivíduo em condições diferenciadas.

\section{Referências}

ARCAFAR SUL - ASSOCIAÇÃO REGIONAL DAS CASAS FAMILIARES RURAIS DO SUL DO BRASIL. Quem somos? Disponível em: www.arcafarsul.org.br. Acesso em: 15 set. 2017.

ASSUNÇÃO, C. e BORGES, R. "Etnomatemática e Pedagogia da Alternância: elo entre saber matemático e práticas sociais”. Revista Latinoamericana de Etnomatemática, v. 5, n. 1, pp. 4-34, 2012.

AUED, B. W. e VENDRAMINI, C. R. (orgs.). Educação do campo: desafios teóricos epráticos. Florianópolis: Insular, 2009.

BERNARDI, L. T. M. S. et al. "O desafio de ser professor na escola do campo: o contexto da Casa Familiar Rural Santo Agostinho”. Reflexão e Ação, v. 22, n. 2, pp. 120-42, Santa Cruz do Sul, jul.-dez. 2014.

CALDART, R. S. A escola do campo em movimento. Porto Alegre: 2000.

PUIG-CALVÓ, P. e GARCIA-MARIRRODRIGA, R. Formação em Alternância e desenvolvimento local: o movimento educativo nos CEFFA do mundo. Belo Horizonte: O Lutador, 2010.

CASTRO, R. R. O papel da Casa Família Rural de Altamira na formação técnica de jovens do campo (monografia). UFPA, 2011.

CONCEIÇÃO, J. J. e RODRIGUES, J. C. “Caminhos da sustentabilidade: análise preliminar das práticas pedagógicas e o ensino aprendizagem dos alunos na Escola Família Agrícola Rio Peixe - Balsas/MA". Geosaberes, v. 3, n. 5, pp. 69-81, Fortaleza, jan.-jun. 2012. 
DETOGNI, A. A. e ZANCANELLA, Y. “Casa Familiar Rural de Coronel Vivida - PR: desafios da formação continuada em Pedagogia da Alternância”. Revista Brasileira de Educação do Campo, v. 1, n. 1, pp. 47-70, Tocantinópolis, jan.-jun. 2016.

GIMONET, J. -C. Praticar e compreender a pedagogia da alternância dos CEFFA. Petrópolis: Vozes; Paris: AIMFR - Associação Internacional dos Movimentos de Formação Rural, 2007.

JESUS, J. N. “A pedagogia da alternância e o debate da educação no/do campo no estado de Goiás". Revista NERA, ano 14, n. 18, pp. 7-20, Presidente Prudente, jan.-jun. 2011.

KLEIN, C. "A questão do gênero e a Pedagogia da Alternância na Casa Familiar Rural de São José do Cedro (SC)”. Pedagógica, ano 16, v. 14, n. 29, jul.-dez. 2012.

KRÜGER, M. B. J. Além dos muros da escola: um estudo sobre os campos de atuação do pedagogo. (monografia). UNIJUÍ, 2016

LINDE, K. e WILLICH, S. N. "How objective are systematic reviews? Differences between reviews on complementary medicine". Journal of the Royal Society of Medicine, v. 96, pp. 17-22, 2003.

LOURENZI, L. et al. A contribuição da ciência geográfica na formação social dos sujeitos do campo. Disponível em: http://www.unifra.br/eventos/ sepe2012/Trabalhos/5375.pdf. Acesso em: 15 set. 2017.

MORO, I. L. "Práticas pedagógicas em geografia na perspectiva da Pedagogia de Alternância”. Geosaberes, v. 7, n. 13, pp. 123-36, Fortaleza, jul.-dez. 2016.

MOURA, E. A. de. Lugar, saberes e educação do campo: o caso da Escola Municipal de Ensino Fundamental José Paim de Oliveira - Distrito de São Valentim, Santa Maria, RS (dissertação). Universidade Federal de Santa Maria, 2009.

MONTEIRO, Alexandrina. "Reflexões sobre a organização do trabalho pedagógico: os "tempos" na educação do campo". In: BRASIL. Secretaria de Educação Básica. Diretoria de Apoio à Gestão Educacional. Pacto nacional pela alfabetização na idade certa: educação, matemática do campo. Ministério da Educação, Secretaria de Educação Básica, Diretoria de Apoio à Gestão Educacional. Brasília: MEC, SEB, 2014. 
OLIVEIRA, A. M. "A Escola Camponesa na Alternância e o ensino de Geografia”. Mercator, v. 12, n. 27, pp. 171-87, Fortaleza, jan.-abr. 2013.

OLIVEIRA, A. U. de. "Geografia agrária: perspectivas no início do século XXI”. In OLIVEIRA, Ariovaldo U. de e MARQUES, Marta Inês Medeiros (orgs.). O campo no século XXI: território de vida, de luta e de construção da justiça social. São Paulo: Casa amarela; Paz e Terra, 2004. pp. 27-64.

PORTAL DE PERIÓDICOS CAPES/MEC. Disponível em: https://www. periodicos.capes.gov.br/. Acesso em: 11 set. 2017.

PORTUGAL, J. F. et al. "A Biologia na Pedagogia da Alternância: perspectivas e desafios de uma ciência natural integrada a Casa Familiar Rural de Altamira-Pará.Amazônia”. Revista de Educação em Ciências e Matemática, v. 12, n.24, pp. 73-84, jan.-jul. 2016.

QUEIROZ, J. B. P. de et al. Pedagogia da Alternância: construindo a educação do campo. Goiânia: UCG; Brasília: Universa, 2006.

ROSA, J. S. da e VENDRUSCULO, R. A formação dos educadores na pedagogia da alternância: para uma educação do campo. Disponível em: http:// coral.ufsm.br/. Acesso em: 13 out. 2017.

SAMUA, D. M. et al. Pedagogia da Alternância e extensão rural. Frederico Westphalen: URI, 2012. Disponível em: http://www.scielo.org/php/index.php. Acesso em: 11 set. 2016.

SILVA, U. R. e NERY, V. S. "Pedagogia da Alternância no Amapá: um estudo na Escola Família Agrícola do Pacuí”. Eventos Pedagógicos, v. 7, n. 3, pp. 1.604-29, Sinop, ago.-dez. 2016.

SILVEIRA, L. S. e PERIPOLLI, O. J. “O currículo e suas inquietações no campo: uma análise da proposta curricular da Escola Municipal São Manuel em Colorado do Norte - Mato Grosso". Eventos Pedagógicos, v. 7, n. 3, pp. 1.459-83, Sinop, ago.-dez. 2016.

TEODORO, R. B. et al. "A pedagogia da alternância na construção do desenvolvimento rural do Vale do Jequitinhonha, Minas Gerais". Sociedade Brasileira de Economia, Administração e Sociologia Rural (SOBER), 46th Congress, 20-23 de julho de 2008, Rio Branco, Acre, Brazil. 
UNEFAB - União Nacional das Escolas Famílias Agrícolas do Brasil. Disponível em: http://unefab.org.br/home/num_efasbr.htm. Acesso em: 15 set. 2017.

VIEIRA FILHO, R. E. J. e FISHLOW, A. Agricultura e indústria no Brasil: inovação e competitividade. 2013. Repositório do Conhecimento do IPEA. Disponível em: https://bit.ly/2ytx8Z7. Acesso em: 13 out. 2017. 


\title{
A formação de professores na educação quilombola e seus desafios contemporâneos
}

\author{
Dilmar Luiz Lopes \\ Claudete dos Santos da Silva
}

\section{Questões introdutórias}

Os processos educativos são instituídos e instituem-se em práticas socioculturais, e, no caso brasileiro, as relações étnico-raciais demarcam um modo específico de expressão de saberes no cotidianamente escolar e não escolar. Assim, o desafio é pesquisar, estudar, ensinar e dialogar com as raízes históricas e filosóficas ou ainda com as visões de mundo originariamente indígenas, africanas hoje expressas como heranças das ancestralidades daqueles que, nesse território, construíram e reconstruíram suas vidas e seus pertencimentos étnicos. Tais narrativas não privilegiam uma única maneira de ser e de estar no mundo, como referência e padrão, mas exploram as diferenças na perspectiva do diálogo e da pluralidade e apontam para a interculturalidade como nova forma de viver as relações sociais. $\mathrm{O}$ desafio é compreender o contexto rural como um terreno fecundo para a emergência de práticas educativas que ajudem a repensar a formação de professores, a partir da inclusão dos saberes locais no currículo escolar. A semântica de uma formação enraizada na cultura, nos valores, nos modos de conhecer da realidade camponesa e com todo o movimento que há nele pergunta: quais os limites, desafios e perspectivas da formação de professores da educação do meio rural em escolas que atendem a educandos de comunidades quilombolas no Rio Grande do Sul?

A questão que se procura desvelar está objetivamente inscrita nas práticas e, em particular, nas relações sociais que a condicionam, sejam elas de nível territorial e cultural. Sob a perspectiva educativa, é uma tentativa de ampliar 
os espaços-tempos formativos, desenvolvidos por instituições e universidades que constituem tópicos importantes da investigação. O que está em jogo é a emergência das experiências educativas específicas como uma modalidade educativa a contribuir nas arenas de formação docente na educação do campo. Ao analisar a linguagem, narrativa e escrita, tem-se em vista seu papel na constituição da natureza social e histórica dos sujeitos, em particular no que se refere aos desafios da formação de professores.

\section{Aspectos metodológicos da pesquisa}

O lócus da pesquisa são duas comunidades quilombolas do estado do Rio Grande do Sul, o que justifica a necessidade de acompanhar as ações voltadas para a formação de professores da educação escolar básica do campo. Os instrumentos para coleta e análise são: pesquisa documental, entrevistas, observação participante e rodas de conversa. Já os sujeitos da pesquisa são: a) a Escola Municipal de Ensino Fundamental Gabriel Obino, localizada no quilombo urbano dos Alpes, região metropolitana de Porto Alegre, e possui o reconhecimento da Fundação Palmares; b) a Escola Municipal de Ensino Fundamental Manoel Albino de Carvalho, localizada dentro da comunidade de São Miguel, região central, interior de Restinga Seca, já possui o decreto de desapropriação por interesse social e também recebeu recursos para infraestrutura, tais como ginásio, biblioteca, refeitório e salas de aula. A pesquisa assume as características de um estudo qualitativo, do tipo participante (Brandão, 2001; Triviños, 2008). À luz de uma interpretação fenomenológica, pensa-se que esse novo conhecimento precisa ser produzido de outra forma, mais horizontal, compartilhado e local, uma espécie de ecologia de saberes, ${ }^{1}$ resultado de uma rica experiência construída na interlocução entre os sujeitos da pesquisa e os pesquisadores.

\footnotetext{
${ }^{1}$ É traduzir saberes em outros saberes, traduzir práticas e sujeitos de uns aos outros, é buscar inteligibilidade, sem homogeneização. A ecologia das temporalidades, a ecologia dos reconhecimentos, a ecologia das transescalas e a ecologia da produtividade (Santos, 2007).
} 


\section{0 contexto emergente da temática quilombola}

Os desafios emergentes da conjuntura democrática dos anos 1980 viabilizam diversas manifestações culturais da população afro-brasileira. Somente a Constituição Federal de 1988 permitiu uma abertura por meio da qual o negro teve acesso a diversos espaços territoriais. Nesse período, o movimento negro organizou marchas com o intuito de denunciar o racismo presente na sociedade brasileira e trabalhou na perspectiva da autoestima e identidade negra referendada pelas rodas de samba e capoeira, entre outras. Tal movimento ajudou ainda na elaboração de propostas, programas de políticas públicas para conquista de direitos da população negra.

É nessa conjunção de forças que se afirma o artigo 68 das Disposições Transitórias (Constituição da República Federativa do Brasil, de 1988), que cobra do Estado brasileiro o direito ao território e educação. Além disso, outro marco da luta quilombola foi a grande marcha pela memória do Tricentenário de Zumbi dos Palmares, no ano de 1995. Um ponto alto foi a entrega de uma série de reivindicações do Movimento Quilombola, que pressionava o Estado brasileiro. As principais pautas passam pela denúncia do racismo institucional como elemento estruturante das relações sociais, melhoria da infraestrutura das comunidades, demarcação do território e uma educação específica com qualidade. No conjunto dessas políticas públicas, o país tem sido um caso singular na América Latina, tendo nas ações afirmativas focadas na educação seu melhor desempenho. No entanto, o compartilhamento de políticas tendo como alvo as comunidades quilombolas não tem tido a mesma eficácia em termos de reconhecimento, titulação das áreas e educação.

A chegada ao poder de governos de cunho popular ajuda a institucionalizar algumas demandas, mencionadas acima. É o caso do artigo 26-A, ${ }^{2}$ parágrafo $4^{\circ}$. da Lei de Diretrizes e Bases da Educação Nacional, de 1996, que, ao apontar que a história do Brasil levará em conta as contribuições das diferentes culturas e etnias para a formação do povo brasileiro, reconhece a contribuição dos povos negros e indígenas para o país nas áreas social, econômica e política, bem como os valores civilizatórios da cultura africana e afro-brasileira.

${ }^{2}$ Lei n. ${ }^{\circ}$ 10.639/03 e Lei n. ${ }^{0} 11.645 / 08$, que altera os artigos 26-A e 79-B da Lei de Diretrizes e Bases da Educação Nacional. 
Para Pereira (2008), o contexto da criação de um marco regulatório expressa um debate social amplificado e o empenho de vários cidadãos com a construção de uma sociedade justa, consciente das dimensões sociais, militantes, de pesquisadores, conselhos escolares e gestores públicos da educação. O que essas legislações apontam para o cenário da educação contemporânea é a importância da diversidade cultural, orientações e formas de abordagens a determinados conteúdos programáticos, dando visibilidade a esses sujeitos. O texto das diretrizes educacionais também sugere alternativas para a formação de professores e prática docente, alertando para a necessidade de um trabalho multidisciplinar. Trouxe grandes desafios para as diferentes instâncias dos sistemas escolares - é preciso qualificar os professores em exercício, é necessário que os cursos de licenciaturas formem professores para atender tais dispositivos. Ainda, os projetos político-pedagógicos das escolas precisam estabelecer os valores civilizatórios da cultura negra por dentro dos currículos escolares, e as secretarias, junto com a gestão escolar, têm de estabelecer parcerias com o movimento social organizado para que o povo negro se torne sujeito das ações a serem executadas. É o caso da educação quilombola.

\section{Diretrizes e práticas quilombolas na promoção da diversidade}

Ao navegar na conjunção de forças favoráveis, o movimento quilombola, em parceria com intelectuais negros, começa a pensar em uma proposta de educação que contemple as especificidades quilombolas. Após várias audiências públicas (Maranhão, Bahia, Brasília e Rio Grande do Sul), emerge o conceito de Educação Escolar Quilombola enquanto uma modalidade educativa. As Diretrizes Curriculares Nacionais Gerais para a Educação Básica, capítulo II, artigo 41, de 13 de julho de 2010, já apontavam nessa direção.

\footnotetext{
A Educação Escolar Quilombola é desenvolvida em unidades educacionais inscritas em suas terras e cultura, requerendo pedagogia própria em respeito à especificidade étnico-cultural de cada comunidade e formação específica de seu quadro docente, observando os princípios que orientam a Educação Brasileira (Brasil, 2010).
}

Alguns conceitos emergentes do debate nacional ajudam a pensar a dimensão epistemológica e pedagógica desse ensino. Que educação escolar ga- 
rante o território de que os grupos quilombolas precisam? Isso significa dizer que a educação precisa expressar o espaço vivido e seus contextos de territorialidades. O território dialoga com as Diretrizes da Educação Escolar Quilombola (2012), com as ações afirmativas e com os diversos campos do saber?

Houve o consenso de que a educação escolar quilombola precisa estar preocupada em proporcionar mecanismos de estímulo à continuidade dos estudos dos jovens, para que eles cheguem ao Ensino Superior tendo consciência do legado histórico dos antigos remanescentes de quilombos. E, principalmente, mantenham-se fortalecidos na identidade cultural e racial negra brasileira. Isso permite melhora na estima dos jovens estudantes remanescentes quanto à identificação como descendentes dos africanos, bem como pode reforçar vínculos com seu meio de origem.

O protagonismo se dará com as comunidades num processo construtivo. Nesse sentido, toda a comunidade estaria envolvida na definição dos quadros profissionais necessários ao seu desenvolvimento e na definição das estratégias políticas e educacionais de manutenção da educação e território, numa prática de ensino que reforça os saberes do cotidiano e o conhecimento científico que estão implicados. Na dimensão institucional, foi preciso estabelecer a educação na direção da formação continuada e a titulação do território como um dos eixos estruturantes dessa política.

A formação de professores nessas escolas se caracteriza por uma linha pedagógica para/com/dos quilombos, mas dialoga com as outras matrizes fundadoras do país. É uma educação para o território, para dentro e fora dele, numa visão dinâmica entre "nós e os outros" (Todorov, 1993), entre o que vem de dentro da escola e o que vem de fora com as práticas sociais quilombolas, mediado pelo projeto político-pedagógico, o currículo e o fortalecimento de saberes locais.

\section{Formação de professores em processos}

Como se sabe, a formação de professores é tema central de um conjunto significativo de estudos e pesquisas (André, 2010) já há algum tempo, bem como das mais recentes políticas educacionais que sinalizam metas para qualificação e valorização dos profissionais da educação.

Nessa direção, Nóvoa (2007, p. 2) evidencia o atual "regresso dos professores ao centro das nossas preocupações e das nossas políticas como personagens 
insubstituíveis na promoção de aprendizagens, nos desafios da diversidade e na utilização das novas tecnologias". Tal afirmativa baseia-se na prerrogativa de que ensinar exige aprendizagem constante por parte dos profissionais da educação, ou seja, professores devem responsabilizar-se profissionalmente por sua aprendizagem, o que implica qualificação permanente para o enfrentamento das complexas demandas contemporâneas. Nesse ponto de vista, esse processo não se restringe a uma formação inicial ou continuada, embora assim se denominem essas etapas formativas. Freire (1998, p. 24) foi categórico ao afirmar que "não há docência sem discência". Essas duas formas, resguardando-se as diferenças, são papéis cotidianos na vida dos professores.

A profissão docente, de acordo com Sacristán (1999), é partilhada na sociedade e possui uma dimensão conflituosa em que os significados divergem entre grupos sociais, econômicos e culturais. Essa afirmação torna-se evidente quando, por exemplo, se veem professores defendendo suas crenças, seus valores, suas ideologias, ${ }^{3}$ que, embora nem sempre coerentes com suas ações, divergem significativamente entre si. No entanto, quando se pensa a formação a partir da concepção de profissional reflexivo, urge valorizar a prática docente como um momento da construção de conhecimento, por meio da problematização, reflexão e análise. Assim concebida, a formação docente dificilmente deixaria de encontrar alternativas para o enfrentamento das questóes etnorraciais que emergem ao longo dos tempos.

A partir desses pressupostos, tem-se investido em uma formação que contemple as necessidades e expectativas dos docentes, resguardando-se seus pontos de vista e, ao mesmo tempo, incidindo-se em uma qualificação pedagógica, até porque se entende que "os embates de fronteira acerca da diferença cultural têm tanta possibilidade de serem consensuais quanto conflituosos" (Bhabha, 2010, p. 21). Cabe destacar que as pequenas mudanças que ocorrem na sociedade bem como na educação se dão a passos lentos; o tempo revela limites e desafios em qualquer proposta de implementação de políticas de formação.

Há uma certa inquietude na sociedade, escola e docentes em relação ao campo temático para se apoderar de questões envolvendo identidades, preconceitos, relações interétnicas, o que demonstra certa fragilidade na formação e

\footnotetext{
${ }^{3}$ Compreendendo ideologia, de acordo com Hall (2009, p. 250), como "os referenciais mentais" - linguagens, conceitos, categorias, conjunto de imagens do pensamento e sistema de representação - que as diferentes classes e grupos sociais empregam para dar sentido, definir, decifrar e tornar inteligível a forma como a sociedade funciona.
} 
resistência em aceitar as diversas manifestações culturais. O desafio maior é compreender o processo de formação nas relações interculturais e as dimensões aprendentes que daí emergem, em que o professor é o sujeito de sua aprendizagem.

Segundo Lopes e Galvão (2010), em Território plural, na história da educação brasileira, nos últimos 50 anos, valorizam-se cada vez mais os sujeitos invizibilizados da história, como crianças, mulheres, quilombolas, indígenas e as camadas populares. Aí, sentimentos, emoções, memórias e narrativas também fazem parte dessa história, na qual o protagonismo dos sujeitos é muito importante.

\section{Formação de professores e os saberes locais}

Os saberes locais que se encontram dentro da comunidade e a formação de professores precisam caminhar juntos. Numa relação dialógica, a segunda não pode se sobrepor à primeira, reconhecendo que os saberes locais serão balizados pelo conhecimento científico, no qual o ensino não seria somente o da ciência acumulada, mas a experiência mediada pelo senso comum e a cultura. Numa concepção gramsciana, a ciência só adquire sentido se melhora a vida das pessoas (Gramsci, 1989). Com o avanço da sociedade, ciência e tecnologia, tivemos grandes transformações sociais, políticas, econômicas e culturais que influenciaram o conhecimento, neste último século. Essas mudanças sem precedentes afetam visivelmente o espaço educativo escolar: o como, o quê e o para quê as crianças e os jovens aprendem nas escolas (Coll, 1994). Dentro dessa visão teórico-metodológica, valorizam-se os saberes e as práticas dos sujeitos das escolas, e afirma-se o cotidiano como lócus privilegiado da discussão curricular. Assim, nestes pequenos saltos que vinham ocorrendo com os povos tradicionais por meio de políticas e Diretrizes Curriculares (2004), foi preciso redefinir o que aprender e ensinar na Educação Básica para os quilombolas.

Sabe-se que é na relação entre território e educação em circunstâncias históricas que se aprende o cotidiano da exploração, do racismo, bem como a própria ressignificação do saber da tradição, agora voltado para o empoderamento da comunidade. A escola que interessa é aquela que ensina ciência vinculada ao movimento que cria as condições de aprendizagens, forma e conteúdo curriculares. Uma escola que não negue o saber produzido coleti- 
vamente no interior da comunidade, nos movimentos de luta, nas diferentes manifestações culturais, nas festas; pelo contrário, que seja o lócus onde esse saber seja bem elaborado e se constitua num instrumento para aperfeiçoar direitos e deveres. Cabe também problematizar aspectos teórico-metodológicos, pedagógicos das questões gerais para sua concretização específica dentro do contexto da formação de professores. Em que sentido o conhecimento histórico, geográfico pode iluminar concretamente os professores que atuam na instituição escolar em áreas remanescentes de quilombos?

Vislumbramos, num primeiro plano de ação, a articulação política específica do trabalho escolar com as necessidades dessas comunidades. Trata-se da investigação da especificidade e evolução da organização do processo de educação das relações étnico-raciais, do papel do Estado e da relação orgânica com os movimentos sociais, nas diferentes formas de ensinar e aprender das associações, intelectuais e lideranças quilombolas. Uma concepção de ensino embasada nas narrativas e histórias que as próprias lideranças da comunidade carregam, sem desperdiçar a experiência acumulada.

\section{Narrativas como elementos da formação de professores}

Em síntese, um percurso formativo pedagógico capaz de retroalimentar a memória quilombola ocorre por meio das narrativas que recuperam uma das dimensões das africanidades. A dimensão da narrativa ${ }^{4}$ torna-se um recurso pedagógico que ajuda na orientação de caminhos para a formação de educadores que atuam em comunidades quilombolas, não de maneira estática, mas dialeticamente articulado aos aspectos culturais e simbólicos que orientam suas vidas. É um processo fazedor do mundo, bem como um processo revelador do mundo. A realidade e o significado das histórias contadas geram a busca por uma nova voz, que tem no horizonte a justiça.

Pedagogicamente falando, essas narrativas e metáforas não são respostas prontas para pensar a educação quilombola, mas se tornam insights para trazer à tona a memória rebelde do grupo que se orienta pelos elementos de eticidade e liberdade. Também se apresentam na forma de novos saberes que

\footnotetext{
${ }^{4}$ História contada por alguém. Narração de acontecimentos, ações, fatos ou particularidades relativas a um determinado assunto (Dicionário Aurélio, 2010).
} 
operam na perspectiva da formação e potencializam novas teorias pedagógicas, no intuito de materializar a educação.

Para José Carlos dos Anjos (2004, p. 64), a premência primeira que rege a estruturação dessas narrativas é uma tentativa de recolocar em ordem o mundo vivido.

Efetivamente, todo o conjunto de narrativas pertinente à fundação de quilombos nos remete para a polarização entre o tempo do cativeiro e o tempo pós-abolição. Essas narrações nos apresentam um passado amorfo, no qual se cristaliza um único acontecimento - desafio à ordem escravista. Esse desafio constitui o fundamental da esquematização da concepção de justiça e caráter do povo. [...] a memória coletiva cristaliza uma série de ícones que opõem a liberdade ao cativeiro, a bondade à injustiça, a submissão ao caráter.

Essas narrativas nos ajudam a entender a origem do território, configurada pelo mulato, e o desafio da hierarquia racial, o negro negociando na escravidão e os senhores brancos seduzindo o grupo, ora com regras de justiça, ora como representação da injustiça. Do ponto de vista pedagógico, o fator determinante é a reflexão que tal fato provoca. Essas histórias narradas reforçam as experiências coletivas e práticas de resistência na manutenção de seus modos de vida característicos num determinado lugar.

Em síntese, ao recontar a história de comunidades quilombolas, um processo de formação ajuda a territorializar esses espaços de resistência e de direitos.

\section{Algumas considerações finais}

Buscamos explorar a hipótese de que as políticas públicas de formação de professores por si só não conseguem estabelecer novos elementos às práticas educativas, sem o protagonismo das comunidades. Ou ainda, no plano escolar e educativo, as questões colocadas para uma educação do campo em territórios quilombolas estão diretamente ligadas à dinâmica de investigação das práticas pedagógicas portadoras de mudança e de esperança, que estão presentes nas comunidades. À medida que acontecem mediações entre as políticas públicas de formação com as práticas sociais e escolares dessas 
comunidades, é possível propor novos conhecimentos que potencializem a educação do campo. Um dos elementos inovadores emerge do saber/fazer dos grupos quilombolas que combinam narrativas e metáforas como forma de linguagem transgressora capaz de potencializar um currículo centrado no conhecimento local e global.

Algumas conclusões demonstram que o ponto de partida dos saberes quilombolas consiste em estabelecer a relação entre o que está dentro do território e o que vem pela educação continuada para reforçar os elementos que se encontram nas localidades, sem perder de vista os desafios globais, da ciência e sociedade. Outro resultado mostra que o ensino se constitui por meio das histórias contadas e forma o amálgama que sustenta o significado da educação que começa em casa, avança pelo território, chega à escola e se espalha pelo mundo. Nesse local, a memória tem um aspecto reparador na aprendizagem, não apenas porque remete ao passado/presente, mas também porque aponta para horizontes.

Por fim, o território se constitui como o lugar privilegiado que está sendo constantemente ressignificado nos fazeres da família, do trabalho, da escola e das organizações sociais que atualizam cotidianamente seu sentido. Para ambos, a educação se materializa na forma de territorialidades, na perspectiva de uma proposta pedagógica dos quilombos. É claro que este artigo não tem a pretensão de estabelecer o conteúdo para a formação de professores, mas apenas apontar elementos teóricos/metodológicos que ajudem nessa direção.

\section{Referências}

ANDRÉ, Marli. “A pesquisa sobre a formação de professores: contribuições à delimitação do campo". In SOARES, Leôncio et al. (orgs.). Convergências e tensões no campo da formação e do trabalho docente. Belo Horizonte: Autêntica, 2010.

ANJOS, José Carlos Gomes e SILVA, Sergio Baptista da. (orgs.). São Miguel e Rincão dos Martimianos: ancestralidade negra e direitos territoriais. Porto Alegre: Editora da UFRGS, 2004.

BHABHA, Homi K. O local da cultura. Belo Horizonte: Editora UFMG, 2010. 
BRANDÃO, Carlos R. (org.) Repensando a pesquisa participante. São Paulo: Brasiliense, 2001.

BRASIL. Ministério da Educação. Lei de Diretrizes e Bases da Educação Brasileira. Brasília, 1996.

- Ministério da Educação. Diretrizes Curriculares Nacionais para a Educação das Relações Étnico-Raciais e para o Ensino de História e Cultura Afro-Brasileira e Africana. Brasília, 2005.

. Conferência Nacional de Educação. Brasília: CONAE, 2010.

. Diretrizes Curriculares Nacionais Gerais para a Educação Básica. Resolução no 4. Brasília, 13 de julho de 2010.

. MEC/CNE/CEB. Resolução no 8. Define Diretrizes Curriculares Nacionais para a Educação Escolar Quilombola na Educação Básica. Brasília, 2012.

COLL, César. Aprendizagem escolar e construção do conhecimento. Porto Alegre: Artmed, 1994.

FREIRE, Paulo. Pedagogia da autonomia: saberes necessários à prática educativa. São Paulo: Paz e Terra, 1998.

GALVÃO, Ana Maria de Oliveira e LOPES, Eliane Marta Teixeira. Território plural: a pesquisa em história da educação. São Paulo: Ática, 2010.

GILROY, Paul. O Atlântico negro: modernidade e dupla consciência. Trad. Cid Knipel Moreira. São Paulo: Editora 34; Rio de Janeiro: Universidade Cândido Mendes, Centro de Estudos Afro-Asiáticos, 2001.

GRAMSCI, Antônio. Os intelectuais e a organização da cultura. Trad. Carlos Nelson Coutinho. Rio de Janeiro: Civilização Brasileira, 2 ed. 1978 e 4 ed. 1989.

HALL, Stuart. Da Diáspora: identidades e mediações culturais. Belo Horizonte: UFMG, 2009.

NÓVOA, A. (org.). Vidas de professores. 2 ed. Porto: Porto Editora, 2007.

PEREIRA, Júnia Sales. "Reconhecendo ou construindo uma polaridade étnico-identitária? Desafios do ensino de história no imediato contex- 
to pós-Lei n. ${ }^{\circ} 10.639 ”$. Estudos Históricos, v. 21, n. 41, pp. 21-43, Rio de Janeiro, 2008.

SACRISTÁN, J. Gimeno. Poderes instáveis em educação. Trad. Beatriz Affonso Neves. Porto Alegre: Artmed, 1999.

SANTOS, B. S. Renovar a teoria critica e reinventar a emancipação social. São Paulo: Boitempo Editorial, 2007.

TODOROV, Tzvetan. Nós e os outros: a reflexão francesa sobre a diversidade bumana. Rio de Janeiro: Zahar, 1993.

TRIVIÑOS, A. Introdução à pesquisa em ciências sociais: a pesquisa qualitativa em educação. São Paulo: Atlas, 2008. 


\title{
A luta por educação do campo no Colégio Estadual do Reassentamento São Marcos - município de Catanduvas/PR
}

\author{
Edimar Rodrigo Rossetto \\ Marli Terezinha Szumilo Schlosser
}

Introdução

Neste capítulo, será apresentada, de forma sucinta, a ação de lideranças da Comissão Regional dos Atingidos por Barragens da Bacia do Rio Iguaçu Crabi, na luta por direitos educacionais na comunidade do Reassentamento São Marcos, localizado no interior do município de Catanduvas, extremo oeste paranaense. A partir da conquista do reassentamento, a pauta das lutas do movimento foi a construção e a manutenção do colégio do campo. Esse processo tornou-se o tema central desta pesquisa.

O Colégio Estadual do Reassentamento São Marcos é símbolo da articulação popular em defesa da educação para as comunidades reassentadas. Localizado no oeste paranaense, especificamente no município de Catanduvas, o colégio está vinculado institucionalmente ao Núcleo Regional da Educação de Cascavel - NRE.

A respeito do período da construção do Colégio Estadual do Reassentamento São Marcos, é importante destacar o apoio contínuo recebido dos sujeitos expropriados na Usina Hidrelétrica Governador José Richa (Salto Caxias), os quais destinaram dias de luta em prol da educação no colégio do reassentamento.

Para tanto, analisa-se, como ponto principal, o projeto político-pedagógico (PPP) da instituição de ensino, tendo-se em vista a organização das ações/ 
atividades desenvolvidas no cotidiano, vinculadas diretamente ao Movimento da Educação do Campo, com o qual os integrantes do colégio afirmam estar adaptando as práticas pedagógicas.

Este capítulo é resultado do trabalho dissertativo intitulado "O projeto formativo de educação do campo do Movimento dos Atingidos por Barragens (MAB) no oeste e no sudoeste paranaense", vinculado ao Programa de Pós-Graduação em Geografia (PPGG) da Universidade Estadual do Oeste do Paraná (UNIOESTE), campus de Francisco Beltrão, defendido no ano de 2015. A metodologia consiste em garimpagem bibliográfica por meio de obras, teses, dissertações e monografias referentes ao tema trabalhado. As análises das entrevistas com lideranças e comunidade escolar se fizeram importantes, bem como a aplicação de 22 questionários fechados para uma turma do $1 .^{\circ}$ ano, duas turmas de $2 .^{\circ}$ ano e uma turma de 3. ano do Ensino Médio, com a porcentagem de $50 \%$ de alunos presentes no dia da visita. Torna-se importante enfatizar o registro de campo e análise de documentos do movimento social e colégio. Objetiva-se relacionar os dados coletados, juntamente com entrevistas para lideranças e imagens, nas instituições pesquisadas, com o que prevê a proposta de Educação do Campo. Esta tem maior afinidade de características com a luta por educação oriunda dos movimentos sociais.

A pesquisa caracteriza-se como qualitativa e recai na vertente marxista, que apresenta análise contra-hegemônica dos documentos institucionais, como, no caso, o PPP, relacionando-o com a práxis da proposta de Educação do Campo em sua essência.

Nesse sentido, a partir do contexto de implantação de usinas hidrelétricas no estado do Paraná, movimentos populares se formam e adquirem respaldo em suas reivindicaçóes. As regióes oeste e sudoeste paranaense representam o foco da pesquisa a partir da construção da Usina Governador José Richa (Salto Caxias), construída no leito do Rio Iguaçu. Essa obra redimensionou a dinâmica econômica e social da região afetada e de proximidades, expulsando milhares de agricultores, posseiros, ribeirinhos, vileiros, entre outros povos da localidade, dando lugar à criação do lago da usina. Nesse contexto, as comunidades do campo não se aquietaram e unificaram suas lutas contra o projeto hidrelétrico posto, cuja construção estava a cargo da Companhia Paranaense de Energia Elétrica - Copel.

A partir da força popular local, cria-se a Crabi, no sentido de reivindicar os direitos da população expropriada com a obra. Nesse sentido, a exigência da comissão popular era a realocação das comunidades camponesas em novas áre- 
as, de forma que as perdas dos sujeitos atingidos fossem minimizadas. Assim, a Copel foi conduzida a reassentar as famílias prejudicadas, adquirindo dez áreas na região oeste do Paraná, sendo uma delas o Reassentamento São Marcos.

A luta, porém, não terminou apenas com a garantia da terra. Foi preciso lutar também por condições infraestruturais como, por exemplo, moradia, redes elétricas, estradas, como requisitos mínimos para a vida em comunidade. A principal luta era quanto à construção de instituições de ensino. Assim, no Reassentamento São Marcos, localizado no município de Catanduvas, a Crabi conquistou a implementação do Colégio Estadual do Reassentamento São Marcos. Essa instituição representa o foco da pesquisa, que analisa a visão de educandos, das lideranças escolares e da comunidade, entre outros, no funcionamento e na organização das práticas pedagógicas.

\section{A construção do projeto político-pedagógico do Colégio Estadual do Reassentamento São Marcos e seus entraves}

Como as instituições educacionais são fruto da luta dos sujeitos do campo e o MAB está inserido na luta por um projeto formativo de educação voltado aos interesses das comunidades do campo, a memória de luta do movimento que se insere no dia a dia escolar, por meio de um projeto de escola viva, torna-se importante para a realidade do campo. Objetiva-se garantir a manutenção dos traços organizacionais de vida em comunidade, como é o caso da conservação das tradições, das crenças e dos costumes que, em parte, se perderam com a entrada do capital no campo, desrraigando-se as comunidades de seus locais de origem. Esse fortalecimento do humanístico nas relações sociais ocorre no processo de ensino-aprendizagem, ou seja, nas salas de aula do colégio analisado.

Os resultados da pesquisa desenvolvida foram expostos a partir da análise de documentos específicos da instituição, como no caso do projeto político-pedagógico e por meio da aplicação dos questionários fechados para os educandos do Ensino Médio do Colégio Estadual do Reassentamento São Marcos.

Em relação ao PPP do Colégio Estadual do Reassentamento São Marcos, pontua-se que sua estrutura de organização e legislação está disposta por meio de artigos ao estilo burocrático. Sendo assim, observa-se que sua estrutura legislativa é idêntica à de PPPs de instituições educacionais urbanas. A diferença que avulta dessa instituição em relação às demais urbanas é quanto à sua localização física, ou seja, no espaço rural. 
O Colégio Estadual do Reassentamento São Marcos, objeto de análise deste capítulo, localiza-se nas proximidades da Rodovia BR-277, km 540, zona rural do município de Catanduvas, oeste do estado do Paraná. Atualmente, suas ações de funcionamento, como, por exemplo, manutenção de instalações, funcionários, luz e outras despesas, são custeadas pela Secretaria de Estado da Educação - SEED/PR. A figura 1 ilustra parte do Colégio Estadual do Reassentamento São Marcos.

Em relação aos níveis e às modalidades de ensino da Educação Básica, observa-se:

Art. $52 \mathrm{O}$ estabelecimento de ensino oferta:

I. Ensino Fundamental: $5^{\mathrm{a}}$ a $8^{\mathrm{a}}$ séries/regime de 8 anos;

II. Ensino Médio;

III. Educação Especial: sala de recurso de $5^{\text {a a }} 8^{a}$ série, apoio especializado no atendimento de alunos com deficiência mental e distúrbios de aprendizagem (Paraná, 2010, pp. 39-40).

Figura 1: Vista lateral do Colégio Estadual do Reassentamento São Marcos

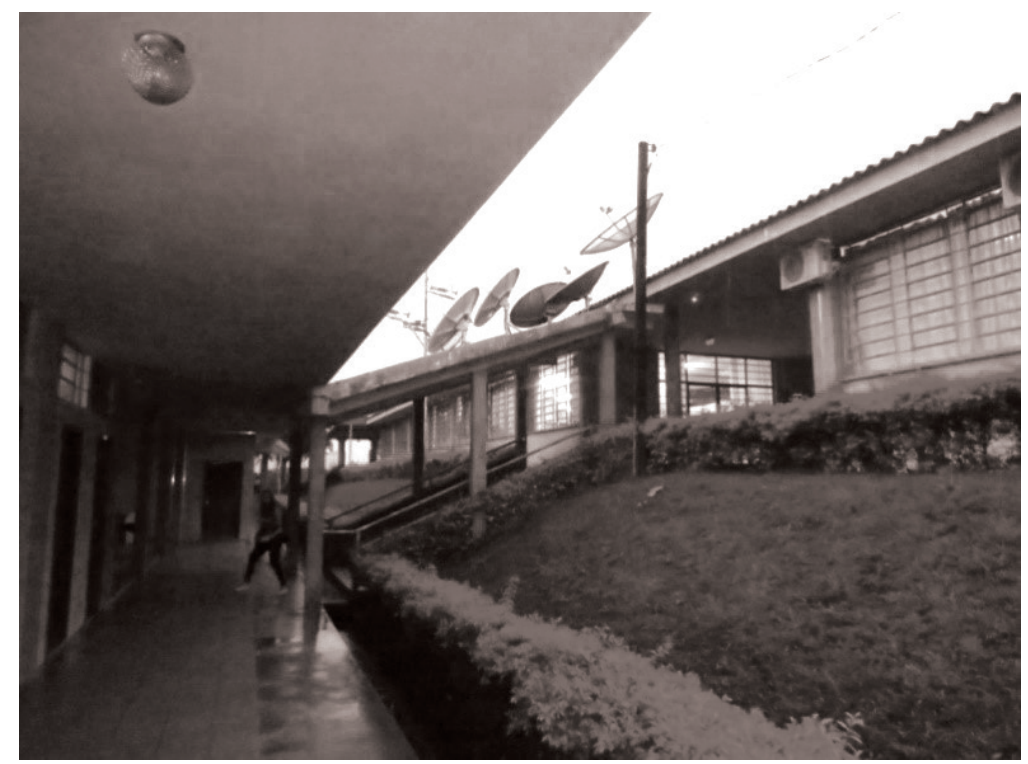

Fonte: Rossetto, Edimar Rodrigo. Colégio Estadual do Reassentamento São Marcos. 2014. 
Contudo, é importante mencionar que o regime seriado, de oito anos, foi alterado e cumpre as novas regras com tempo mínimo de nove anos, conforme a reformulação promovida em 4 de abril de 2013, em relação à Lei de Diretrizes e Bases da Educação Nacional (LDB) - Lei Federal n. ${ }^{\circ}$ 9394/1996.

No artigo 64 desse documento, observa-se que o estabelecimento de ensino oferta salas de apoio à aprendizagem para os anos finais do Ensino Fundamental, conforme orientações da SEED (Paraná, 2010, p. 41). Faz-se relevante apontar que as atividades de apoio e aprendizagem não se desenvolvem em local específico, como previsto no artigo, sendo tais espaços definidos diariamente, ou seja, no ato do desenvolvimento da atividade, conforme a necessidade. Isso porque há carência de espaços específicos na instituição para a realização dessas atividades. Em várias ocasiões, é utilizado o espaço da biblioteca ou o da sala de professores, ou mesmo o do saguão, entre outros.

Quanto à matriz curricular da instituição de ensino, as disciplinas que fazem parte da grade curricular cumprem as normativas estabelecidas pela LDB de 1996, pelas Diretrizes Curriculares Nacionais (DCNs), pelas Diretrizes Curriculares Estaduais (DCEs), etc. Como se observa no artigo 2. do PPP,

o Colégio Estadual do Reassentamento São Marcos tem a finalidade de efetivar o processo de apropriação do conhecimento, respeitando os dispositivos constitucionais Federal e Estadual, a Lei de Diretrizes e Bases da Educação Nacional - LDBEN no 9.394/96, o Estatuto da Criança e do Adolescente - ECA, Lei no 8.069/90 e a Legislação do Sistema Estadual de Ensino (Paraná, 2010, p. 23).

Observa-se, no conjunto de leis que fundamentam esse documento, que não são levadas em conta as especificidades da Educação do Campo, embora sejam especificidades embasadas na Constituição Federal brasileira a partir das Diretrizes Operacionais para a Educação Básica nas Escolas do Campo. É, porém, importante frisar que o artigo 5. do PPP está em desacordo com o projeto de escola do campo, afirmando que "o estabelecimento de ensino, em seu Projeto Político-Pedagógico, atenderá às Diretrizes Operacionais para a Educação Básica nas Escolas do Campo" (Paraná, 2010, p. 23). Como dito, não há existência de trechos das Diretrizes Operacionais no documento analisado, não justificando seu uso. Cabe lembrar que o PPP é o documento que rege as ações/atividades na instituição de ensino, orientando e definindo rumos a serem seguidos pelo estabelecimento ao longo dos anos. Esse PPP não traz profundas 
alterações em seu projeto quanto à aproximação do movimento de Educação do Campo. O colégio, apesar de não garantir, especificamente, em seu principal documento, artigos que tratam do processo pedagógico diferenciado para o campo, apresenta elementos que fortalecem a identidade dos sujeitos do campo a partir de suas práticas diárias, elencadas individualmente no outro item.

É possível apontar que o PPP desse colégio é embasado a partir dos interesses da escola urbana, observando-se o trecho da entrevista concedida pela coordenadora do Núcleo Regional da Educação (NRE), Madalena Suchesi, do município de Cascavel/PR, que afirma que o "PPP, muitas vezes da escola urbana, [...] vem simplesmente clonado para a escola que passa a se chamar do campo, mas ela está no campo, os professores reproduzem a mesma aula do urbano para o campo, mas a escola se chama escola do campo".

Dessa forma, trata-se de perceber que o espaço educacional do campo consiste na lógica de trabalho e de educação específicas, a fim de reproduzir a forma de ensinar do campo, ou seja, priorizando as necessidades da própria comunidade camponesa quanto a suas práticas de vida e de trabalho. Nessa linha de análise, é preciso perceber que o PPP deve ser seriamente discutido e construído pelos líderes locais, pois

\begin{abstract}
constitui-se em instrumento de ação político-pedagógica e de gestão, na medida em que possibilita a manifestação dos desejos e aspirações da comunidade em termos da educação das crianças e jovens, e norteia todo o processo educativo desencadeado pela escola. Nesse sentido, não pode ser visto apenas como produto ou resultado de um trabalho de definição de finalidades e linhas de ação (Gordo, 2015, s.p.).
\end{abstract}

Assim, para a construção desse documento, é preciso pensar o espaço pedagógico da instituição, tornando-o instrumento educativo a fim de nortear o cotidiano de vida dos educandos e comunidade a partir de suas práticas. Essas práticas são caracterizadas por meio de uma terminologia denominada de "temporalidade pedagógica"1 do colégio, refletindo-se diretamente no

\footnotetext{
${ }^{1}$ Terminologia de cunho histórico-geográfico para explicar a velocidade na realização das ações em determinada esfera de análise no conjunto da fluidez do modo de produção capitalista. O colégio do campo, por se constituir uma base teórica de ideologia contra-hegemônica, tem suas práticas pedagógicas alicerçadas no tempo de organização do modo de produção capitalista.
} 
"tempo do campo", ${ }^{2}$ priorizando os valores e a cultura dos sujeitos que ali residem.

Em relação à estrutura do PPP em questão, cabe destacar que, além de seus próprios artigos, os demais documentos do estabelecimento de ensino são engajados. Entre eles, o Regimento Escolar do estabelecimento, efetivado no ano de 2008, e a proposta pedagógica curricular (PPC), a qual orienta a matriz curricular do colégio em questão.

No artigo $4 .^{\circ}$ do PPP, observa-se que "o estabelecimento de ensino objetiva a implementação e acompanhamento do seu projeto político-pedagógico, elaborado coletivamente, com observância aos princípios democráticos, e submetido à aprovação do Conselho Escolar" (Paraná, 2010, p. 23).

Quanto ao artigo 11 do PPP, que diz respeito à composição de representantes dos vários setores da sociedade no Conselho Escolar da Instituição, é importante ressaltar a participação dos movimentos sociais, representando, no máximo, $1 / 5$ do total de membros, constituindo, nesse caso, como porcentagem baixa de membros dessa esfera nesse conjunto. Cabe lembrar que a principal função desse conselho é acompanhar, efetivar e aprovar o PPP da instituição.

Em relação à organização representativa dos educandos no colégio, observa-se que:

Art. $1^{\circ}$ - O Grêmio Estudantil JUFE - Jovens Unidos Futuro Exemplar é o órgão de máxima representação dos estudantes do Colégio Estadual do Reassentamento São Marcos localizado na cidade de Catanduvas e fundado em 05/11/2005 (cinco de novembro de dois mil e cinco), com sede neste Estabelecimento de Ensino.

Parágrafo Único - As atividades do Grêmio reger-se-ão pelo presente Estatuto aprovado em Assembleia Geral convocada para este fim (Paraná, 2010, p. 103).

\footnotetext{
${ }^{2}$ A expressão mencionada tem função de destacar que, apesar de o "tempo rápido" do modo de produção capitalista interferir na dinâmica de funcionamento das instituições educacionais do campo, o espaço rural pode ainda ser visto como engajado em um movimento descontínuo, porém, que expresse uma visão para além da produção; ou seja, um lugar de vida, de convivência humana, de solidariedade e de esperança na construção de uma sociedade enraizada em sua cultura local.
} 
Nesse sentido, a partir do ano de 2005, criou-se o Grêmio Estudantil no colégio. Como prevê o estatuto, o grêmio é consolidado apenas por educandos da instituição. É importante mencionar que esse órgão representativo expressa, por meio de seus representantes, a posição dos educandos desse colégio quanto às necessidades a serem discutidas pelo Conselho Escolar, além de possuir representação também nesse conselho. A figura 2 ilustra uma das atividades realizadas pelo Grêmio Estudantil no colégio.

A construção do mural tem função de mostrar o trabalho dessa organização e de aglutinar ainda mais educandos em suas discussões. Cabe, porém, mencionar que as discussões realizadas pelo Grêmio Estudantil, na sua grande maioria, não fazem referência à luta do movimento social em questão, não incluindo a comunidade nas ações realizadas pelo colégio. As principais ações desse órgão se pautam na organização de atividades de recreação para os educandos que frequentam a instituição.

Figura 2 - Mural no saguão do Colégio Estadual do Reassentamento São Marcos

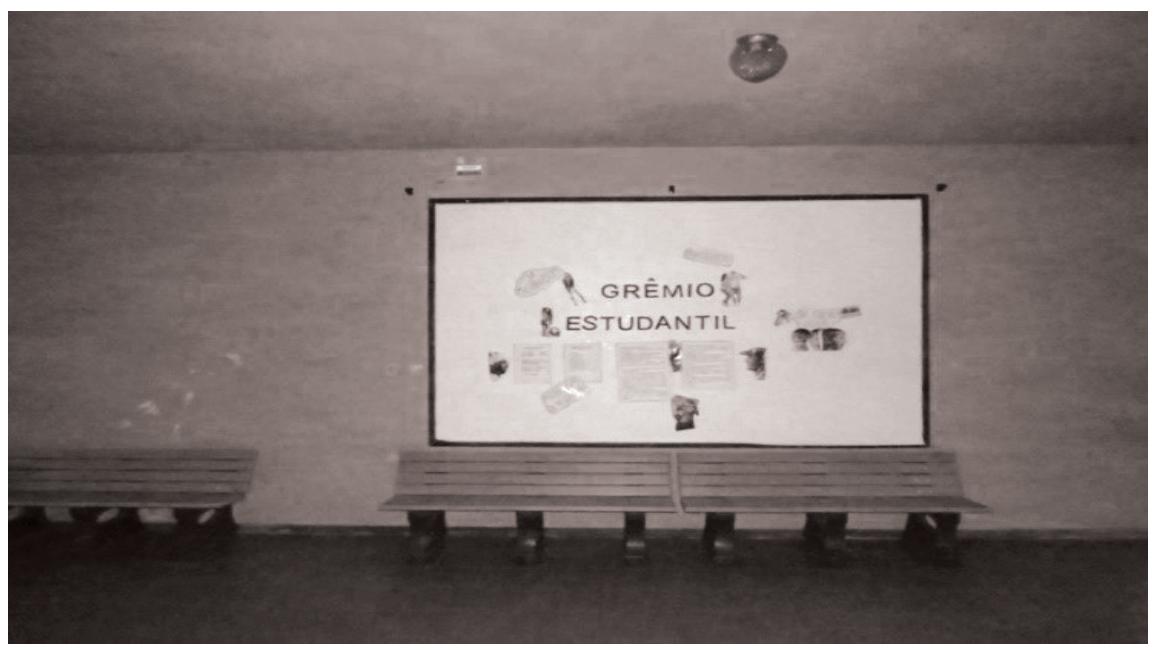

Fonte: Rossetto, Edimar Rodrigo. Colégio Estadual do Reassentamento São Marcos. 2014. 
Em relação ao disposto no artigo 154, observa-se que "a biblioteca é um espaço pedagógico democrático com acervo bibliográfico à disposição de toda a comunidade escolar" (Paraná, 2010, p. 53). A biblioteca do Colégio Estadual do Reassentamento São Marcos encontra-se ilustrada na figura 3.

É importante observar que a biblioteca, estando à disposição da comunidade escolar, poderia destinar seu acervo de livros e materiais também à comunidade local, uma vez que o colégio está em processo de mudança de nomenclatura para colégio do campo, tendo seu conselho escolar composto também por membros da comunidade local. Esse local, além de servir como espaço para leitura, é destinado para uso comum de educandos na preparação de trabalhos do Grêmio Estudantil, sala de reforço, ações pedagógicas, entre outras atividades. É, ainda, caracterizado como espaço de utilidade pública da comunidade escolar nos períodos matutino, vespertino e noturno.

Figura 3: Biblioteca do Colégio Estadual do Reassentamento São Marcos

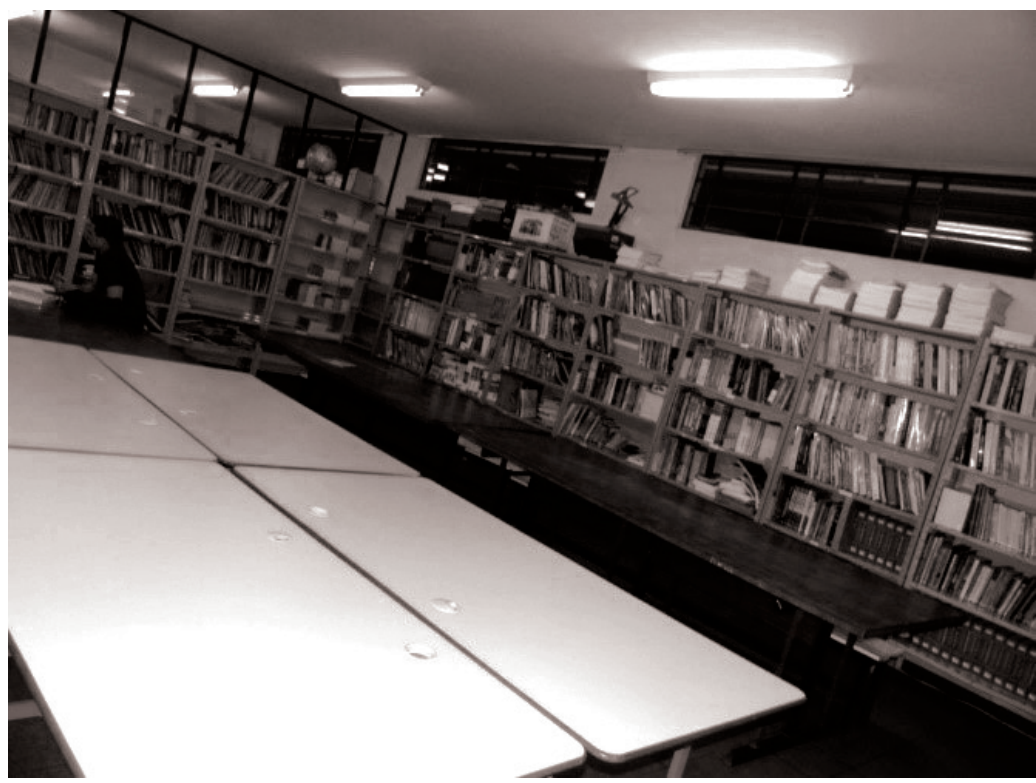

Fonte: Rossetto, Edimar Rodrigo. Colégio Estadual do Reassentamento São Marcos. 2014. 
À frente das ações realizadas no ambiente da biblioteca do colégio, encontra-se a funcionária Zenir Grobes. Referente à responsabilização do espaço destinado à biblioteca, é importante destacar algumas funções da liderança, como, por exemplo, a classificação de livros, o zelo e a organização dos materiais, o controle de empréstimos, etc. É pertinente destacar, na entrevista concedida pela educadora, que,

\begin{abstract}
Na questão da biblioteca, a minha decisão por estar aqui é porque nós temos um material muito grande referente à realidade da escola do campo, não só da nossa, como experiências de outras escolas que deram certo, o meu objetivo é formar esses alunos conscientes de que aonde eles aprendam a trabalhar, a lidar com o campo, porque na roça não é você só capinar, você têm um número de coisas a mais para fazer, hoje a diversificação da propriedade é muito importante. Não precisa você trabalhar somente com o cultivo de plantas, você pode trabalhar com horta, com alimentos para a compra direta, que vem para as escolas e que eles também podem trabalhar com panificação.
\end{abstract}

Nessa linha de raciocínio, pode-se considerar que a bibliotecária Zenir cumpre função extremamente importante no colégio, firmando-se como liderança na luta da comunidade escolar por uma educação direcionada às comunidades do campo. Como frisado pela líder, a diversificação de atividades no meio rural caracteriza-se como elemento de extrema importância no crescimento e no fortalecimento da agricultura em pequenas e médias propriedades, gerando renda e disponibilizando qualidade de vida no campo. Essa alternativa pode ser caracterizada, nos dias atuais, como sendo profícua na manutenção das famílias no campo.

Acrescenta-se a tudo isso que a ação das lideranças locais na organização dos trabalhos administrativos e pedagógicos, seja das instituições de ensino pesquisadas, seja da própria comunidade, apesar de não darem conta do que prevê o movimento de Educação do Campo em sua essência, representa o alicerce na luta pela manutenção e funcionamento dessas instituições educacionais. Diante de dificuldades enfrentadas cotidianamente por este colégio, é preciso que haja sempre sujeitos comprometidos com a educação e com o futuro das próximas gerações no campo, para que a luta não termine. 


\section{Traços da luta cotidiana de educadores e educandos por educação do campo no Colégio Estadual do Reassentamento São Marcos}

Em relação à pesquisa empírica, observa-se que, no Colégio Estadual do Reassentamento São Marcos, a mensuração dos dados coletados foi plotada a partir da organização de quadros para questões de duas alternativas, gráficos para questões com mais de duas alternativas, além da relação com os trechos das entrevistas das lideranças. Nesse colégio, foram coletados 22 questionários, considerando-se que esse número representa a porcentagem de $50 \%$ dos educandos presentes no dia da coleta, pertencentes a quatro turmas, sendo elas do Ensino Médio da instituição. As turmas analisadas foram uma do $1 .^{\circ}$ ano, duas turmas de $2 .^{\circ}$ ano e uma turma de $3 .^{\circ}$ ano. O quadro la expressa a posição dos educandos segundo a proposta de Educação do Campo e a visão deles quanto ao questionário aplicado.

Quadro 1a: questionário aplicado no Colégio Estadual do Reassentamento São Marcos

\begin{tabular}{|c|c|c|c|c|}
\hline N.o & $\begin{array}{c}\text { Dados do 1.0 ao 3.0 ano- Ensino } \\
\text { Médio - Colégio Estadual do Reas- } \\
\text { sentamento Sáo Marcos (\%) }\end{array}$ & SIM & NÃO & RESPONDERAM \\
\hline 1 & $\begin{array}{c}\text { A biblioteca da escola supre as neces- } \\
\text { sidades de pesquisa dos alunos? }\end{array}$ & 86 & 14 & 0 \\
\hline 2 & $\begin{array}{c}\text { A estrutura física da escola propor- } \\
\text { ciona condiçóes de aprendizagem? }\end{array}$ & 95 & 05 & 0 \\
\hline 3 & $\begin{array}{c}\text { Sáo discutidos conteúdos do campo } \\
\text { em sala de aula? }\end{array}$ & 73 & 27 & 0 \\
\hline 4 & $\begin{array}{c}\text { Quando se formar, pretende perma- } \\
\text { necer no campo? }\end{array}$ & 55 & 45 & 0 \\
\hline 5 & $\begin{array}{c}\text { Trabalhar os conteúdos do campo na } \\
\text { escola é importante? }\end{array}$ & 91 & 09 & 0 \\
\hline 6 & $\begin{array}{c}\text { Você gosta de como são trabalhados } \\
\text { os conteúdos na escola? }\end{array}$ & 82 & 18 & 22 \\
\hline & $\begin{array}{c}\text { Total de alunos que responderam ao } \\
\text { questionário }\end{array}$ & & & 0 \\
\hline
\end{tabular}

Fonte: Rossetto, Edimar Rodrigo, março de 2014. 
Na pergunta de número 1, observa-se que a maioria dos respondentes, $86 \%$ dos educandos, considera a biblioteca da instituição estruturada, suprindo as necessidades de pesquisa a serem feitas. Segundo relatos da líder Zenir Grobes, a biblioteca tem função primordial nas ações pedagógicas do colégio, principalmente por disponibilizar espaço para a confecção de trabalhos, pela quantidade e qualidade do acervo de pesquisa etc.

Em relação à pergunta de número 2, que consiste em averiguar se a condição física do prédio da instituição, construído no padrão arquitetônico da SEED-PR, proporciona condições de aprendizagem, 95\% dos educandos afirmam estar satisfeitos com as estruturas, sendo propícias ao aprendizado.

É importante mencionar que, conforme as discussões de autores primordiais para os estudos da proposta de Educação do Campo, a construção do espaço físico da instituição de ensino do campo deve atender aos interesses da comunidade a que pertence. Nesse sentido, a verdade é que a construção segue a organicidade estrutural do espaço urbano, ou seja, está sob supervisão do Núcleo Regional da Educação vigente. Como, atualmente, o colégio está em processo de mudança da proposta pedagógica educacional, que será direcionada para o campo, conforme previsto no PPP, essa proposta não poderá ser inteiramente adequada, já que a estrutura física será preservada nos padrões arquitetônicos construídos.

Na pergunta de número 3 do questionário, aproximadamente 3/4 dos educandos afirmam que os conteúdos do campo são discutidos em sala de aula. Nesse momento, vale lembrar o trecho da fala do diretor do Colégio Estadual do Reassentamento São Marcos, Gérson Antônio Pavan, ao observar que

a maioria dos professores fazem isso, embora eles tenham dificuldades pra compreender, tem dificuldades pra fazer da Educação do Campo, uma educação diferente, mas eles, em todas as discussões, nas reuniões pedagógicas a gente tem tocado nesse assunto de procurar valorizar os saberes que eles têm, que possuem, que trazem de casa e sempre que possível poder associar os conteúdos com a realidade dos alunos (informação verbal). ${ }^{3}$

\footnotetext{
${ }^{3}$ Gérson Antônio Pavan. Entrevista I. [mar. 2014]. Entrevistador: Edimar Rodrigo Rossetto. Catanduvas, 2014. 1 arquivo. $\operatorname{dvf}(33 \mathrm{~min}$.).
} 
Segundo análises dos educandos da instituição, a maioria dos professores não está desenvolvendo aulas de campo frequentemente. Isso talvez se deva ao alto grau de rotatividade dos professores e à elevada concentração de docentes contratados a partir do processo seletivo simplificado (PSS). Com isso, a vinda de professores urbanos torna-se expressiva na instituição, mas parte deles desconhece os objetivos da proposta de educação na qual o colégio está se inserindo e tampouco conhece a realidade dos educandos, reproduzindo, em parte, uma aula desvinculada da realidade do campo.

$\mathrm{Na}$ questão de número 4, que se refere à permanência do jovem no campo, observa-se que $55 \%$ dos educandos manifestam a intenção de permanecer no campo depois de se formarem, o que representa um prévio resultado das atividades das lideranças na promoção de uma educação voltada para o bem-estar e a vida no campo.

$\mathrm{Na}$ questão de número 5 , que aborda a importância dos conteúdos do campo na escola, observa-se que $91 \%$ dos educandos veem acuidade no aprendizado dos conteúdos de suas realidades. Nessa linha de análise, cabe destacar, segundo o diretor da instituição, Gérson Antônio Pavan:

nosso objetivo é trazer os alunos pra escola em tempo integral, à tarde eles estudam asdisciplinas normais e na parte da manhã nós pretendemos trabalhar as disciplinas diferenciadas, voltadas pra sua realidade, inclusive temos um projeto de horta da escola, para que aprendam como fazer isso em suas propriedades (informação verbal). ${ }^{4}$

É importante considerar que a maioria dessas pautas foi dialogada pela comunidade educacional. Os educandos, assim, veem o surgimento de novas possibilidades para o ingresso profissional e social também no campo. Começa-se a desmistificar os preconceitos entre cidade e campo, e os educandos passam a ver que o espaço em que vivem também é lugar de vida e de trabalho.

Em relação à questão 6 , observa-se que $82 \%$ dos educandos afirmam gostar do modo como são trabalhados os conteúdos do campo, apesar de serem pouco explorados pela instituição. Os outros $18 \%$ dos respondentes

\footnotetext{
${ }^{4}$ Gérson Antônio Pavan. Entrevista I. [mar. 2014]. Entrevistador: Edimar Rodrigo Rossetto. Catanduvas, 2014. 1 arquivo. $\operatorname{dvf}(33 \mathrm{~min}$.)
} 
não gostam das metodologias aplicadas pelos professores no aprendizado de conteúdos do campo. Isso talvez se justificasse pelas formações diferenciadas de cada professor, nos casos em que não ministram nessa escola a disciplina em que possuem a sua titulação ou por não possuírem afinidade com o espaço em que trabalham.

Acerca da questão 7 , que buscou identificar se os professores desenvolvem aulas de campo/práticas, observa-se o resultado da plotagem no gráfico 1.

$\mathrm{Na}$ análise dessa questão, observa-se que aulas de campo não é uma prática comum nesse colégio. Segundo dados plotados no gráfico, a maioria dos respondentes afirma que as aulas de campo raramente acontecem durante os dias letivos.

Gráfico 1: Os professores desenvolvem aulas de campo/práticas?

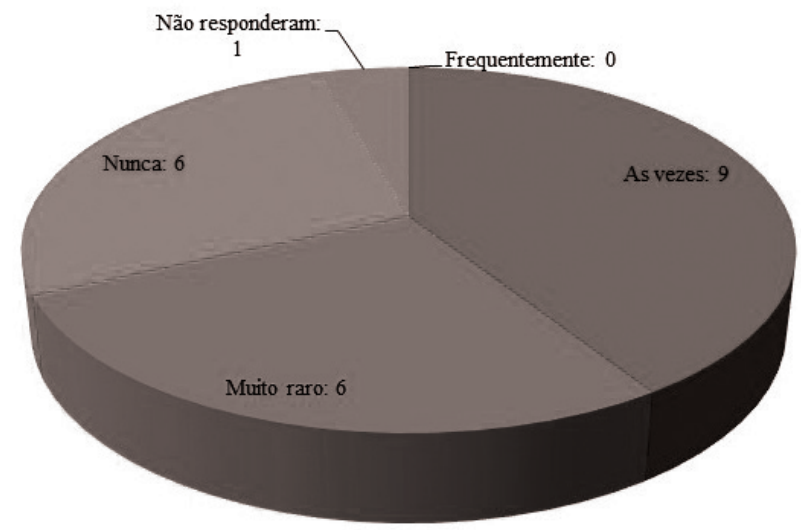

Fonte: Rossetto, Edimar Rodrigo. Confeccionado em março de 2014.

Em relação à questão de número 8 , que busca investigar quais disciplinas trabalham com aulas de campo, observa-se o resultado da plotagem no gráfico 2 .

Segundo análise do gráfico 2, observa-se que a disciplina de Geografia é a que mais trabalha com aulas de campo. Como aponta Micheli Andressa Maziero: 
na Geografia fica mais fácil trabalhar com isso porque você parte do senso comum dele para aí expor o conteúdo científico. $\mathrm{Na}$ verdade, assim, as atividades que eu procuro desenvolver, as paisagens, eu levo os alunos pra fora pra gente ter o conhecimento do espaço geográfico, pra ter essa facilidade pra assimilar o conteúdo, porque a questão científica fica mais difícil, então a partir do momento que eles começam a conhecer o espaço que eles vivem, a questão da Geografia, da localização, fica mais fácil de eles entenderem (informação verbal). ${ }^{5}$

É oportuno dizer que a disciplina de Geografia, por ter seu objeto de investigação em evidência - no caso, o espaço geográfico -, se insere nas relações sociais com facilidade, enquadrando-se na abordagem das discussões continuamente, propiciando sequências consideráveis no envolvimento com as atividades de campo.

Gráfico 2: Quais disciplinas trabalham com aulas de campo?6

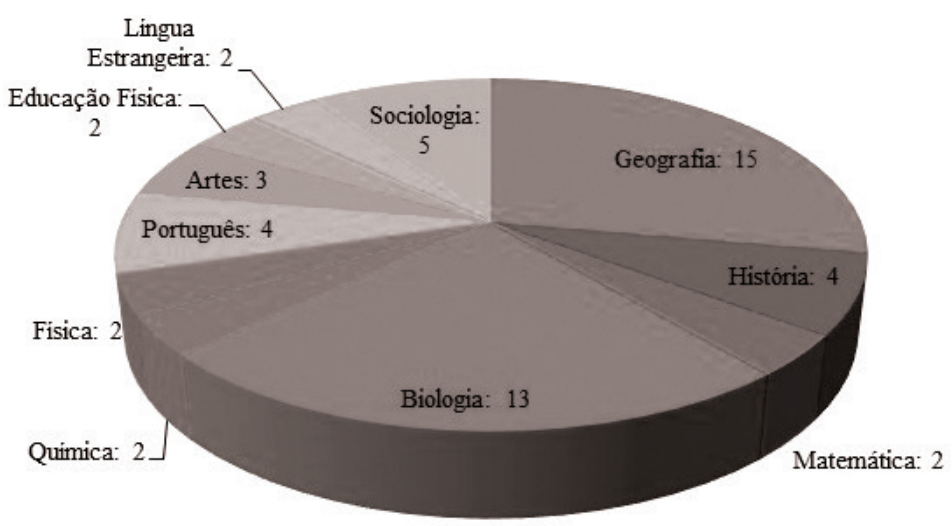

Fonte: Rossetto, Edimar Rodrigo,março de 2014.

\footnotetext{
${ }^{5}$ Micheli Andressa Maziero. Entrevista I. [mar. 2014]. Entrevistador: Edimar Rodrigo Rossetto. Catanduvas, 2014. 1 arquivo. $\operatorname{dvf}(25 \mathrm{~min}$.).

${ }^{6}$ É importante mencionar que, nesta questão, o educando tinha possibilidade de assinalar mais de uma disciplina. Gráfico referente à plotagem de dados coletados no Colégio Estadual do Reassentamento São Marcos, município de Catanduvas/PR, alusiva à pergunta de número 8 do questionário aplicado.
} 
A segunda disciplina que mais trabalha com aulas de campo é a Biologia. O percentual na realização das atividades de campo por essa disciplina pode estar associado à presença da horta do colégio. Segundo Zenir Grobes, "nós temos a horta orgânica, em que a gente pega os alunos e produz os alimentos, e eles se alimentam dessas verduras" (informação verbal). ${ }^{7}$ Essa atividade prática é desenvolvida juntamente ao plano de ensino da disciplina citada.

Em relação à análise das questões 9,10 e 11 do questionário, observa-se o resultado da plotagem no quadro $1 \mathrm{~b}$ :

Quadro 1b: Questionário aplicado no Colégio Estadual do Reassentamento São Marcos

\begin{tabular}{|c|c|c|c|c|}
\hline N.o & $\begin{array}{l}\text { Dados do } 1 .^{\circ} \text { ao } 3 .^{\circ} \text { ano - Ensino } \\
\text { Médio - Colégio Estadual do } \\
\text { Reassentamento Sáo Marcos }(\%)\end{array}$ & SIM & NÃO & $\begin{array}{c}\text { NÃO } \\
\text { RESPONDERAM }\end{array}$ \\
\hline 9 & $\begin{array}{c}\text { A merenda servida na escola é de } \\
\text { qualidade? }\end{array}$ & 82 & 18 & 0 \\
\hline 10 & $\begin{array}{l}\text { Existem aulas práticas que traba- } \\
\text { lham com o cultivo de alimentos } \\
\text { orgânicos? }\end{array}$ & 23 & 77 & 0 \\
\hline 11 & $\begin{array}{l}\text { Existem trabalhos/atividades de- } \\
\text { senvolvidas na escola, por parte } \\
\text { do movimento e comunidade, que } \\
\text { visam fortalecer o jovem na reali- } \\
\text { dade do campo? }\end{array}$ & 59 & 41 & 0 \\
\hline & $\begin{array}{l}\text { Total de alunos que responderam } \\
\text { o questionário }\end{array}$ & & & 22 \\
\hline
\end{tabular}

Fonte: Rossetto, Edimar Rodrigo, março de 2014.

Na questão de número 9, que busca investigar a qualidade da merenda escolar, observa-se que a maioria dos respondentes, $82 \%$, considera a alimentação oferecida pela instituição de boa qualidade. É importante mencionar que a merenda industrializada é disponibilizada pela SEED/PR. Não há queixas quanto à sua qualidade ou sua falta.

Acerca da questão de número 10 , que se refere à existência de aulas práticas que trabalham com o cultivo de alimentos orgânicos, $77 \%$ dos educandos

\footnotetext{
${ }^{7}$ Zenir Grobes. Entrevista I. [mar. 2014]. Entrevistador: Edimar Rodrigo Rossetto. Catanduvas, 2014.
} 
não consideram a realização da prática. Assim, observa-se que há carência dessa prática no conjunto das atividades pedagógicas por parte dos docentes atuantes. Como elencado, tal como no colégio analisado anteriormente, entende-se que o conhecimento da agroecologia é o fundamento básico do trabalho desempenhado pelos docentes que atuam com projetos na horta orgânica, sobretudo na disciplina de Biologia. Assim, é importante mencionar que, segundo Guhur e Toná (2012, p. 64),

\begin{abstract}
a agroecologia exige que o camponês passe a assumir uma posição ativa, de pesquisador das especificidades de seu agroecossistema, para desenvolver tecnologias apropriadas não só às condições locais de solo, relevo, clima e vegetação, mas também às interações ecológicas, sociais, econômicas e culturais. Na perspectiva da agroecologia, essa não pode ser tarefa de especialistas isolados. A agroecologia exige conhecer a dinâmica da natureza e, ao mesmo tempo, agir para a sua transformação.
\end{abstract}

Reafirmando a questão, é importante pontuar que o trabalho com alimentos orgânicos é um dos principais instrumentos de manutenção do agricultor camponês no campo, sendo alternativa de renda nos dias atuais. Nessa escola, porém, os dados apontados estão ligados à ausência na realização de aulas de campo, como acima mencionado.

É pertinente destacar que os resultados explorados nas questões 9 e 10 estão indiretamente ligados à questão de número 11 do questionário, a qual busca averiguar a existência de trabalhos/atividades, por parte de movimentos sociais e comunidade, desenvolvidos no colégio, visando fortalecer a presença dos jovens no campo, com o objetivo de reafirmar seus modos de vida. Nessa questão, 59\% dos educandos respondentes afirmam estar cientes da realização dessas práticas no colégio. Os demais, que compreendem $41 \%$ dos respondentes, discordam, afirmando o abandono e a não integração/inserção da comunidade ou articulações populares no colégio. Assim, pouco interferindo no andamento de implementação da proposta de Educação do Campo.

Observa-se que, sem motivação da própria família e comunidade, sem discussão no conselho escolar quanto à importância das aulas de campo e do cultivo orgânico, entre outras práticas, as lideranças do colégio não conseguem, "sozinhas", avançar nessas questóes. O resultado do debate gerado pode garantir a prática do trabalho de campo não apenas como metodologia 
pedagógica alternativa, mas também como conteúdo a ser inserido na proposta pedagógica curricular (PPC) do colégio.

Em relação à pergunta de número 12 do questionário aplicado, a qual busca identificar a interação das famílias da comunidade nas ações da escola, observa-se o resultado da plotagem no gráfico 3:

Gráfico 3: Interação das famílias nas ações do colégio

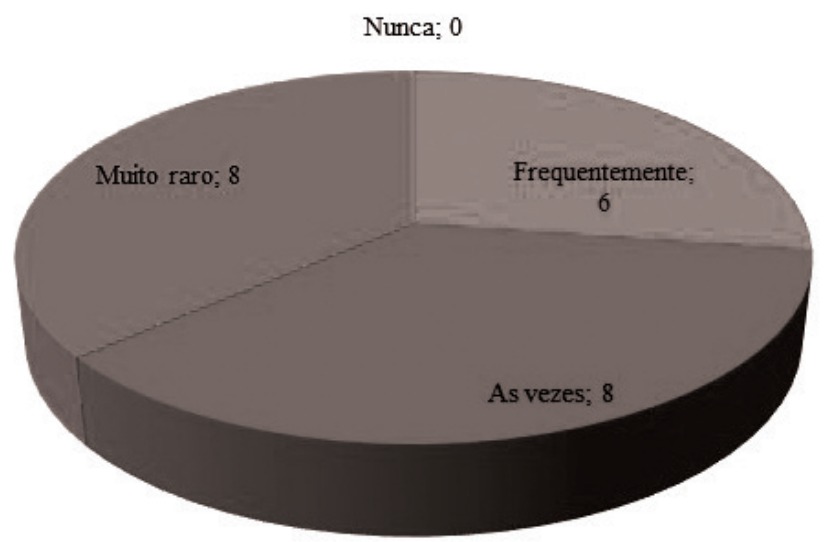

Fonte: Rossetto, Edimar Rodrigo, março de 2014.

$\mathrm{Na}$ análise da questão de número 12 , observa-se que há disparidade nas opções dos respondentes. Dentre os 22 respondentes, 6 educandos afirmam que as famílias interagem com frequência nas ações do colégio. A grande maioria, ou seja, os 16 alunos restantes, divide suas opinióes, haja vista que consideram que as famílias às vezes ou muito raramente participam das ações do colégio.

Essa porcentagem justifica a fraca participação da comunidade nos projetos/atividades/ações realizadas na escola. Considera-se que, para um colégio que está em fase de transição de uma pedagogia de colégio urbano, que passa para uma fase de mudança no viés da proposta de Educação do Campo, o caminho principal para a realização desse trabalho é a união/participação da comunidade do campo nas decisões do colégio. 
Para tanto, é necessário que a comunidade se insira no colégio e implemente sua pedagogia de vida, de trabalho e, principalmente, de organização escolar, para que, assim, seus interesses na busca por um ensino que vise à manutenção dos saberes e das práticas daquela comunidade sejam reafirmados segundo os interesses dos sujeitos que ali vivem. O pressuposto citado faz do colégio, bem como da educação disponibilizada, o elemento de base para a mudança social no campo.

\section{Considerações finais}

A partir do esboço apresentado, permite-se apontar algumas das muitas peculiaridades quanto à efetivação do projeto de escola viva, ou seja, que tenha engajamento com as práticas trazidas pela discussão do movimento da Educação do Campo no Brasil. Muitas atividades deverão ser desenvolvidas, porém, se pontuam também o trabalho cotidiano das lideranças que estão à frente da organização desse espaço escolar. Nesse sentido, observa-se que a comunidade escolar e famílias que nessa região residem estão dispostas a promover mudanças, as quais tenderam a aproximar a escola da família, ou seja, do trabalho no campo, da realidade das crianças camponesas. Intensificar um projeto dessa magnitude representa estar um passo à frente no caminho da cidadania para as comunidades residentes, trazendo esperança de luta coletiva, principalmente para as futuras gerações.

Nesse sentido, cabe à comunidade do campo organizar seu projeto de vida e de trabalho e nele adequar as atividades educativas a fim de garantir a manutenção dos hábitos, das tradições e das crenças, ou seja, a preservação das culturas ali existentes. As pequenas atividades ao longo de determinado período vão gerando frutos que começam a ser colhidos a partir do esforço de povos camponeses, educadores e educandos e demais adeptos que, conjuntamente, trabalham para a transformação futura dos jovens camponeses. 


\section{Referências}

GORDO, Amilton de Moraes. “Os desafios da escola do campo frente ao avanço do agronegócio em Moju: a construção de um PPP (Projeto Político-Pedagógico) democrático e emancipatório". Arcos. Disponível em: http://www.arcos.org.br/artigos/os-desafios-da-escola-do-campo-frente-ao-avanco-do-agronegocio-em-moju-a-construcao-de-um-ppp-projeto-politico-pedagogico-democratico-e-emancipatorio/. Acesso em: 3 mar. 2015.

GOVERNO DO ESTADO DO PARANÁ/SECRETARIA DE ESTADO DA EDUCAÇÃO. Projeto Político-Pedagógico do Colégio Estadual do Reassentamento São Marcos. Catanduvas, 2010.

GUHUR, Dominique Michèle Perioto e TONÁ, Nilciney. "Agroecologia”. In CALDART, Roseli Salete et al. (orgs.). Dicionário da Educação do Campo. Rio de Janeiro: Escola Politécnica de Saúde Joaquim Venâncio; São Paulo: Expressão Popular, 2012.

\section{Entrevistas}

Gérson Antônio Pavan. Entrevista I. [mar. 2014]. Entrevistador: Edimar Rodrigo Rossetto. Catanduvas, 2014. 1 arquivo. dvf (33 min.). Madalena Suchesi. Entrevista I. [mar. 2012]. Entrevistador: Edimar Rodrigo Rossetto. Cascavel, 2012. 1 arquivo. $\operatorname{dvf}$ (70 min.). Micheli Andressa Maziero. Entrevista I. [mar. 2014]. Entrevistador: Edimar Rodrigo Rossetto. Catanduvas, 2014. 1 arquivo. dvf (25 min.). Zenir Grobes. Entrevista I. [mar. 2014]. Entrevistador: Edimar Rodrigo Rossetto. Catanduvas, 2014. 1 arquivo. $\operatorname{dvf}$ (36 min.). 
PARTE III

FormaÇão CONTINUADA DE PROFESSORES 


\title{
Escola rural e formação cidadã
}

\section{Experiência do Projeto Arquitetos do Saber em Cachoeira do Sul/RS}

\author{
Daiane Loreto de Vargas \\ Janete Webler Cancelier \\ Tatiane Almeida Netto
}

\section{Introdução}

A educação é um pilar que permite transformações sociais e culturais da sociedade. Essas mudanças perpassam pela formação de sujeitos capazes de construir, a partir de um senso crítico, ideias novas em relação ao mundo contemporâneo. Para a formação dos sujeitos com tal perspectiva, o princípio da cidadania constitui-se como base elementar, proporcionando ao cidadão o conhecimento da realidade social e, a partir deste, um comprometimento com os fatos dessa realidade. Mas cabe à escola eleger os elementos básicos para a formação dos seus educandos. Sendo assim, é a instituição que decide como os princípios da cidadania serão trabalhados nas estratégias de ensino e aprendizagem do ambiente escolar, e, por consequência dos métodos adotados, os sujeitos serão influenciados no processo de formação vivenciado naquele espaço.

A escolha em seguir princípios de uma formação para a cidadania implica adotar metodologias que possibilitem a construção de ambientes democráticos de participação, onde seja realizada a troca de conhecimentos e experiências entre todos os envolvidos no processo de aprendizagem. Na busca por uma escola que tenha como princípio a formação cidadã, deve-se partir do pressuposto da existência de um diálogo permanente entre os saberes discutidos na escola e as experiências vivenciadas pelos educandos na comunidade. Tal pressuposto tem por objetivo uma aproximação entre teoria e prática na vivência da educação. A educação interpretada e realizada dessa forma pro- 
porciona uma discussão de formação social, cultural e política, contribuindo, assim, para a construção de uma sociedade mais humana, justa e democrática. Esses princípios têm por base a formação de cidadãos politicamente aptos a discutir aspectos relacionados à sua realidade, para, dessa forma, se posicionarem frente às problemáticas sociais vivenciadas.

Pensando essas questões no cenário da educação do campo, é necessário fazer uma reflexão sobre processos educativos estabelecidos nas escolas do campo, tendo em vista a formação dos camponeses e a intencionalidade dessa formação para o trabalho e para a reprodução social destes na contemporaneidade. Portanto, é interessante pensar e discutir sobre como ocorre o processo de formação no campo, por meio de uma educação pensada como projeto educativo mais amplo ou apenas baseado na especificidade da educação escolar, básica ou profissional (Caldart, 2016). A autora ressalta a relevância da construção de uma matriz formativa para a educação dos camponeses, desde a base de concepção e análise da educação do campo até a construção mais ampla do projeto histórico da classe trabalhadora. Nesse sentido, a educação do campo assumiria o desafio de colocar os camponeses como protagonistas do processo de ensino e aprendizagem no campo, levando para o debate no espaço escolar os processos históricos, as lutas sociais e agrárias, bem como o papel central desses trabalhadores no momento social contemporâneo.

A partir dessa percepção, entende-se que a educação do campo requer conhecimento sócio-histórico e que essa construção perpassa pelo olhar de uma educação para a cidadania. Vale destacar que, quando se insiste nas questões Educação e Cidadania, é porque a sociedade ainda carece desses fatores vitais, portanto o pensamento do presente confirma a ausência da verdadeira educação e da autêntica cidadania nos processos educativos (Silva Júnior e Borges Neto, 2011).

A partir da relevância dessa reflexão, as Escolas Estaduais de Ensino Fundamental Honorato de Souza Santos e Monsenhor Armando Teixeira, ambas localizadas no espaço rural de Cachoeira do Sul(RS) assumiram o compromisso, em conjunto com o Projeto Arquitetos do Saber, ${ }^{1}$ da Universi-

\footnotetext{
${ }^{1}$ O Projeto Arquitetos do Saber foi executado pela Universidade Federal de Santa Maria (UFSM), pelo Grupo de Pesquisa Extensão Rural Aplicada, do Departamento de Educação Agrícola e Extensão Rural (DEAER) e do Programa de Pós-Graduação em Extensão Rural, do Centro de Ciências Rurais (CCR), da UFSM, durante os anos de 2010 a 2014. Constituiu-se como sub-projeto do projeto "Novos Talentos", financiado pela Coordenadoria de Aperfeiçoa-
} 
dade Federal de Santa Maria (UFSM), de promover ações com o objetivo de proporcionar uma formação diferenciada e reflexiva. Tais ações seriam pautadas na construção de estratégias de aprendizagem, com base no diálogo e na discussão de uma educação do campo e para a cidadania.

A partir do relato dessa experiência, este artigo tem por objetivo apresentar e discutir ações realizadas e vivenciadas nas escolas supracitadas, especificamente referentes à experiência da cidadania. Pretende-se apontar o desenvolvimento das práticas pedagógicas realizadas no espaço escolar, as quais buscaram potencializar a tomada de atitudes coletivas, democráticas e a conscientização de direitos e deveres, ressaltando a importância da cooperação, participação e construção da cidadania dos sujeitos envolvidos nesse espaço de ensino e aprendizagem.

A experiência relatada está pautada na análise do trabalho realizado nas escolas rurais de Cachoeira do Sul. As informações avaliadas e discutidas são resultado das oficinas realizadas com estudantes da primeira à quinta séries, com cerca de vinte estudantes de cada escola rural.

A atividade realizada pelo Projeto Arquitetos do Saber, com a participação de alunos da pós-graduação da UFSM, de diferentes áreas do conhecimento, em parceria com as escolas rurais do município, proporcionou uma experiência rica e produtiva para jovens estudantes rurais, assim como para os estudantes universitários. A atividade foi realizada com uma visita dos estudantes à Câmara de Vereadores de Cachoeira do Sul, onde se buscou esclarecer como ocorre o processo político e a importância deste para o andamento das ações na cidade.

Inicialmente, estimularam-se um diálogo e a problematização do contexto social em que vivem os estudantes, junto aos familiares, em suas residências, e aos professores, no ambiente escolar. Tal metodologia é apontada por Paulo Freire $(1988,1997)$ como fundamental para a construção do conhecimento. Nesse diálogo, foram destacados os conceitos de educação, cidadania e política. Além disso, buscou-se esclarecer os direitos e os deveres do cidadão e o papel do poder legislativo da cidade, a fim de incentivar uma reflexão e suscitar uma consciência política cidadã.

mento de Pessoal de Nível Superior (Capes) do Ministério da Educação. O “Arquitetos” dividiu suas ações práticas em cinco escolas rurais nos Municípios de Cachoeira do Sul e Novo Cabrais, ambos na região central do estado do Rio Grande do Sul, tendo como norte ações nos eixos de: cidadania, agroecologia e meio ambiente. Todas as escolas que participam do projeto são Instituições Estaduais de Ensino Fundamental. 
Essa dinâmica educativa parte da realidade dos contextos socioculturais, a partir da qual se estruturam propostas pedagógicas para a ação educativa. Isso quer dizer, em termos metodológicos, que a estruturação de propostas de ação pedagógica deve ser desenvolvida por meio do diálogo crítico, envolvendo todos aqueles que são sujeitos do processo (Dayrell, 1996).

A partir desse instrumento metodológico, que visava à multidisciplinaridade, os estudantes construíram uma lista de reinvindicações sociais do ambiente onde vivem, onde estavam presentes as demandas sociais das comunidades rurais.

\section{Educação: do campo e para a cidadania}

A educação rural foi incorporada às políticas educacionais nas primeiras décadas do século XX e teve como prioridade conter o processo migratório do campo para a cidade e elevar a produtividade deste (Silva, 2002). A educação para o espaço rural foi, durante muito tempo, reduzida a uma condição subalterna ao processo educativo do meio urbano, pois o meio rural era visualizado como atrasado e composto por sujeitos de ausências, sem conhecimento, sem importância.

Nesse sentido, a educação no meio rural foi historicamente relegada a espaços marginais nos processos de elaboração e implementação das políticas educacionais na realidade brasileira (Arroyo et al., 2004). A questão pode ser interpretada mediante uma análise sobre as fronteiras entre a educação nos espaços urbanos e rurais "marcadas por construções culturais hegemônicas do meio urbano que tende a inferiorizar, estereotipar e segregar as identidades e subjetividades do meio rural" (Silva Júnior e Borges Netto, 2011, p. 46).

Esse fato é comprovado pela construção tardia de escolas no meio rural e o pouco investimento financeiro do Estado aplicado nessas instituições. Pode-se dizer que a educação rural no Brasil, "por motivos sócioculturais, sempre foi relegada a planos inferiores, e teve por retaguarda ideológica o elitismo acentuado do processo educacional” (Leite, 1999, p. 14). Além disso, o autor destacou que sempre houve uma forte intepretação "político-ideológica da oligarquia" (p. 14).

A desconstrução desse modelo interpretativo de educação, o qual divide espaços e exclui sujeitos, parte da perspectiva do envolvimento e do comprometimento do Estado, como promotor e organizador do desenvolvimento, 
da escola, enquanto mediadora do processo de ensino-aprendizagem, das práticas pedagógicas, da reflexão e discussão das questões sociais, do incentivo ao senso crítico dos sujeitos, e das comunidades onde estão inseridas as demandas e suas formas diferenciadas de vida.

Transformações nesse sentido estão ocorrendo. Tais mudanças têm sido influenciadas principalmente por condicionantes sociais e ambientais, os quais estão exigindo estratégias para o futuro, com diferentes e novas metodologias a serem adotadas, alimentando um debate não somente com o Estado, mas também com as organizações não governamentais, como: associações sindicais, movimentos sociais, grupos sociais determinados, cooperativas, escolas, entre outros (Almeida, 2009).

A normatização da diferenciação de uma educação do campo para uma educação da cidade, mesmo que ainda com falhas, está estabelecida na Constituição Federal de 1988 e na Lei de Diretrizes e Bases da Educação Nacional (LDB) n. 9394/96. No artigo 28, essa Lei estabelece que os sistemas de ensino para a população rural devem se adequar às peculiaridades desse público por meio de:

I - conteúdos curriculares e metodologias apropriadas às reais necessidades e interesses dos alunos da zona rural; II - organização escolar própria, incluindo adequação do calendário escolar às fases do ciclo agrícola e às condições climáticas; III - adequação à natureza do trabalho na zona rural (Brasil, 1996).

O contexto exposto é interpretado por Paulo Freire $(1988,1997)$ como necessário e básico para uma educação popular, mas ainda falho na prática. Mesmo que a reflexão presente seja em torno da educação do campo, é relevante destacar a análise e os princípios utilizados por Freire para definir a educação popular. $\mathrm{Na}$ reflexão ofertada pelo autor, pensar em educação popular é pensar em um processo de ensino-aprendizagem pautado na perspectiva política, como um ato de conhecimento e transformação social. Nessa visão, a principal característica da educação seria a utilização do saber da comunidade como matéria-prima para o ensino, em que a aprendizagem parte do conhecimento do sujeito, e o ensino de palavras e temas geradores do cotidiano da comunidade.

Em outras palavras, Freire entendeu ser necessário construir ações que estimulem a participação da comunidade local, respeitando seus limites e 
ampliando suas potencialidades, sejam elas sociais, ambientais, econômicas ou culturais, acreditando na formação de uma visão crítica da realidade, por meio da qual os indivíduos sejam capazes de discutir, dialogar, trocar, articular e construir junto ao coletivo. Assim, é necessário que as políticas públicas pensem a formação dos formadores, estimulando-os a promover, na prática, transformações sociais, mediante novas estratégias e dinâmicas no âmbito do espaço da escola e da comunidade em torno dela, enfim, da coletividade.

Nesse sentido, o educador tem uma função fundamental, assumindo uma atitude problematizadora e mediadora dos conflitos no ensino-aprendizagem dos estudantes, contextualizando as dinâmicas sociais e culturais das comunidades onde se inserem (Freire, 1997). Faz-se relevante os educadores possuírem uma visão ampliada da realidade dos estudantes, e, nesse processo, a multidisciplinaridade pode contribuir de forma significativa, por meio dos diferentes olhares de várias áreas do conhecimento, que podem interagir, articular e aprimorar novos e diferentes métodos de ensino, pesquisa e extensão, de forma participativa. Demonstra-se, assim, que é possível valorizar o saber cultural dos sujeitos, inclusive resgatar esse saber para discussão no meio acadêmico.

Esse olhar sobre a educação popular para o campo e as formas de aprendizagem implicam o estabelecimento de um diálogo entre o conhecimento ensinado, a cultura e a origem dos educandos. Tais ações são possíveis por meio de metodologias que possibilitem a interação social nas atividades escolares e com novas dinâmicas de aprendizagem, que valorizem os saberes do aluno, sendo os costumes, os valores, as linguagens, as diferenças e a cultura, de uma forma geral, contemplados dentro do plano de ensino da escola e abordados em sala de aula e nos demais espaços.

Por meio da linha de pensamento de Paulo Freire $(1988,1997)$, entende-se a educação como a troca entre aluno e professor e, ao mesmo tempo, como construção do conhecimento, isto é, sempre um está a ensinar algo ao outro. Para isso, é importante que o educador adote uma forma didático-pedagógica que permita ao aluno o pensamento crítico-reflexivo, ou seja, ensine-o a pensar sobre o que está à sua volta, incite a sua curiosidade e também, respeite os saberes que já são intrínsecos a ele e valorize o saber popular. Por fim, ensinar exige crítica sobre a prática.

A educação do campo diferencia-se da educação do meio urbano porque traz, de forma intrínseca, o entendimento do rural como um espaço de vida e trabalho, onde estão inseridos sujeitos com aspectos sociais e culturais diferentes daqueles da população urbana. Nesse sentido, lançar um “olhar para a 
escola pública tem o intuito de provocar o debate sobre políticas educacionais e sobre práticas pedagógicas que, ainda, estão muito distantes de um projeto de desenvolvimento" para o meio rural (Souza, 2016, p. 113).

A educação do campo deve ter por base processos pedagógicos que valorizem o contexto social e cultural dos sujeitos, ressaltando o espaço e a identidade. Nesse sentido, apresentam-se, a seguir, algumas atividades realizadas em duas escolas do campo de Cachoeira do Sul, as quais procuraram o viés da participação social e da cidadania.

\section{As experiências de educação para a cidadania nas escolas rurais de Cachoeira do Sul}

A escola é um local de formação humana, para tanto, ao serem trabalhadas questões de cidadania e política, direitos e deveres, deve-se também considerar as relações impostas pela sociedade - as relações de trabalho, convívio e poder, analogias humanas e sociais que ditam regras, estamentos e posturas diárias. Para tanto, apontar o tema da diversidade e da pluralidade dos sujeitos, seja no espaço rural ou no urbano, e o reconhecimento destes como cidadãos portadores de direitos e deveres é importante, mas, muitas vezes necessita da construção de objetivos pedagógicos que efetivem essas reflexões e ações.

Nessa perspectiva, cabe discutir o papel da escola nos diferentes ambientes e espaços sociais, onde se passa a requerer ações educativas pautadas na cidadania, buscando uma nova concepção de mundo e de relação com o meio (Almeida, 2009). Para isso, é fundamental pensar métodos de ensino e dinâmicas educativas com base em ações participativas, democráticas e coerentes com as diferentes realidades, até porque as comunidades são agentes desse desenvolvimento.

O trabalho realizado por meio de oficinas junto às Escolas Estaduais de Ensino Fundamental Honorato de Souza Santos e Monsenhor Armando Teixeira, ambas localizadas no espaço rural de Cachoeira do Sul, com a participação dos alunos de pós-graduação da UFSM, por meio do Projeto Arquitetos do Saber, proporcionou uma aproximação entre estudantes, professores e a família dos educandos.

Essa aproximação deu-se por meio do diálogo sobre as demandas sociais, econômicas, culturais e ambientais das comunidades rurais, que estão locali- 
zadas no entorno das escolas. A dinâmica organizada pelos pós-graduandos da UFSM e pelos educadores das escolas proporcionou um olhar para o campo, possibilitando que o espaço rural ao redor da escola fosse visualizado por alunos, professores e familiares, ou seja, pela comunidade e, com um mesmo objetivo, detectar as demandas mais emergentes naquele momento e entender a sua motivação.

Observou-se, de forma conjunta, pelos diferentes sujeitos envolvidos (pais, professores, alunos e funcionários das escolas), nessa prática educativa, a diversidade de questões a serem trabalhadas na educação do campo. Nuances diferenciam a realidade das comunidades rurais dos espaços urbanos de educação e convivência social. Citam-se como exemplo a distância percorrida pelos alunos do meio rural até a escola, a necessidade de transporte público e a adequação dos alunos à rotina de trabalho no campo dos pais.

Nesse sentido, percebe-se a importância de difundir a prática pedagógica da problematização, apontada por Paulo Freire (1988) como necessária para a construção de novos conhecimentos e reconstrução das realidades sociais. $\mathrm{Na}$ abordagem estratégia de diálogo e problematização, lançada para os educandos das escolas supracitadas, visualizou-se a aproximação das crianças a seus familiares, possibilitando a construção de uma discussão e análise para a intepretação da realidade social do campo, mas com foco naquelas comunidades. Além disso, apresentaram-se os termos para a problematização "direitos e deveres", os quais, muitas vezes, são distorcidos na interpretação de uma educação, caso esta não esteja pautada no processo sócio-histórico de interpretação da vida dos camponeses.

A partir de reflexões como essa, é possível entender a identidade dessas escolas pela sua vinculação às questões inerentes à sua realidade, ancorando-se na temporalidade e saberes próprios dos estudantes (Brasil, 2001). Assumir essa proposição pressupóe reconhecer a identidade da escola do campo e suas especificidades, assim como a necessidade de adequar métodos didáticos, currículos e calendário escolar, tendo em vista o espaço rural, a vida e o trabalho no campo.

Ao lançar a problemática de pensar sobre os termos "direitos e deveres políticos" aos professores, alunos e seus familiares, estes sujeitos do espaço rural passam a gerar imagens que os refletem como protagonistas da história presente, do ambiente onde vivem. A ação, em sua mais remota intenção, promoveu a identificação de diferentes necessidades deste grupo e que, mesmo diversos, possuem identidades em comum, seja o local de origem, o rural, a 
produção, a história, a cultura e uma identidade onde todos possuem direitos sociais, econômicos e culturais que devem ser respeitados.

Nesse sentido, Brandão (2003) apontou para uma ideia simples, mas fundamental: a de vincular o professor à escola, e a escola à comunidade. Os professores que vivenciam diariamente a escola podem associar, aos afazeres pedagógicos, métodos e técnicas de ação comunitária, que incorporam pequenas pesquisas, organização de unidades de trabalhos comunitários como espaços culturais e de participação social, visando à socialização de pais e alunos ao ambiente escolar do meio rural.

O segundo momento dessa proposta pedagógica constituiu-se com a visita à Câmara de Vereadores de Cachoeira do Sul. Nessa oportunidade, os estudantes conheceram o local, as estruturas, os serviços ofertados, os cargos e as pessoas daquele ambiente, inclusive alguns vereadores que se fizeram presentes para auxiliar o momento pedagógico da oficina, e o vereador que estava como presidente da Câmara naquele momento. Os estudantes, no dia da visita, tiveram uma explanação sobre os três poderes do Estado - Legislativo, Executivo e Judiciário -, a função de cada um deles, e, ainda, foi distribuída a todos os estudantes uma cartilha didática sobre a Câmara de Vereadores daquele município. Para tornar a prática mais educativa, no sentido de abordar o contexto social e cultural daqueles estudantes, procurou-se relacionar as ações práticas do dia a dia, do convívio familiar e da escola com as ideias centrais de direitos e deveres de cada cidadão, de forma a compreender as diversas atribuições dos poderes governamentais.

Contextualizar esse momento de aprendizagem às práticas do dia a dia dos alunos teve por objetivo a interação de suas operações mentais, ligadas a um conteúdo concreto, ou seja, de suas vivências diárias. Utilizar como recurso pedagógico as situações e as imagens que o educando conhece proporciona a ele a interconexão de habilidades e emoções, frente a um corpo de conhecimentos que seja representante significativo do mundo da cultura e do mundo da natureza (Rays, 1996).

No momento da realização da visita, o então presidente da Câmara de Vereadores do município apresentou as funções dos vereadores e como eles devem dirigir-se perante uma sessão. Além disso, passou noções de como funciona uma sessão na Câmara, qual é a função dos vereadores e suas atuais atividades para com a população do município, entre outras questões que envolvem a rotina do Poder Legislativo. 
Aproveitou-se o momento para a realização de uma eleição de vereadores mirins - estudantes foram eleitos aos cargos de vereador, presidente e secretário da Câmara Municipal. Após a eleição, foi realizada a simulação de uma sessão plenária, e os estudantes eleitos se colocaram nas mesas dos vereadores. Já na condição de vereadores, deram início a uma seção "extraordinária", em que foram apresentadas propostas e demandas, bem como discutidas e votadas propostas construídas no momento anterior, junto aos familiares e ao ambiente escolar.

Esse momento possibilitou a vivência do processo legislativo e construiu vínculos de aprendizagem. A perspectiva adotada nessa estratégia de aprendizagem perpassa por um amplo processo, no qual os diferentes espaços e situações sociais vivenciadas na escola e no ambiente familiar agora podem ser levados ao debate em um espaço público, preparado para dar suporte às necessidades da sociedade, um espaço político, como é o Poder Legislativo do município. Importante ressaltar que, nesse campo educativo amplo, estão incluídas as famílias, a escola, a comunidade, o espaço de lazer, de trabalho das famílias, entre outros.

Nos encaminhamentos finais da oficina, os estudantes entregaram ao diretor da Câmara de Vereadores o documento elaborado anteriormente, o qual foi organizado pela professora responsável pela turma, com as reivindicações e propostas construídas junto às famílias e ao ambiente escolar. Colocou-se para o público aquilo que Fernandes (2002, p. 67) destacou como a defesa do "direito que uma população tem de pensar o mundo a partir do lugar onde vive, ou seja, da terra em que pisa, melhor ainda: desde a sua realidade".

O documento entregue abordava diversos temas relacionados às necessidades básicas do indivíduo, necessidades sociais, econômicas e culturais, para a efetiva qualidade de vida. Destacam-se problemas pontuais que dificultam a vida diária das comunidades rurais onde vivem os estudantes e seus familiares, tais como: a) instalação de abrigo na parada de ônibus; b) coleta de resíduos recicláveis; c) necessidade de melhoria na qualidade do abastecimento de água no ambiente escolar; d) instalação de telefonia pública nas comunidades; e) melhorias na estrutura do prédio escolar; f) instalação de postos de saúde nas comunidades; g) diminuição da poluição do ar gerado pelas carvoarias localizadas próximo à escola e às comunidades, uma preocupação ambiental que também afeta a saúde da população naquele local.

Os apontamentos gerados pelo processo de diálogo e problematização junto à escola e às famílias dos educandos apontaram para questões trans- 
versais ao processo educativo no espaço rural (Brasil, 2005). Nesse caso, das escolas rurais de Cachoeira do Sul, destaca-se a relevância de as questões problematizadoras serem pensadas em conjunto, quando surgem problemáticas sociais, políticas, ambientais e econômicas para serem pensadas, e, assim, exigida do poder público a articulação para a resolução das problemáticas.

Arroyo et al. (2004) destacaram que a escolaridade rural deve ter como objetivo principal proporcionar conhecimentos, cidadania e continuidade cultural, por meio de um pensamento crítico e reflexivo, como no caso supracitado. Para Dayrell (1996), o pensamento crítico e autocrítico, mediado pelo diálogo-problematizador, é um elemento permanente para o desenvolvimento, planejamento e replanejamento das atividades pedagógicas simultâneas. Segundo o autor, é por meio de metodologias como essa que se constroem e se transformam de forma permanente os processos sociais vivenciados pelos sujeitos.

\section{Considerações finais}

As atividades realizadas nas Escolas Estaduais de Ensino Fundamental Honorato de Souza Santos e Monsenhor Armando Teixeira, ambas localizadas no espaço rural de Cachoeira do Sul, com a participação dos alunos de pós-graduação da UFSM, por meio do Projeto Arquitetos do Saber, buscou uma aproximação entre a realidade social da escola e das comunidades. Para tal, construiu uma proposta pedagógica que aproximou estudantes, professores e a família dos educandos.

O marco teórico-metodológico para a execução de tais atividades teve como base os autores que buscam o entendimento da educação no campo. Cita-se como exemplo Paulo Freire, destacando-se a importância de diferenciar os processos de ensino e aprendizagem do rural para o urbano, bem como as estratégias metodológicas adotadas, tendo em vista a consideração dos contextos sociais e culturais dos sujeitos envolvidos no processo, em que as singularidades do modo de vida dos alunos do campo precisam ser pensadas a todo o momento, a fim de compreender sua relação com o rural.

Segundo Dayrell (1996), um dos seguidores do pensamento de Paulo Freire, a partir do momento em que se consideram as características de aprendizagem dos educandos, nesse caso dos alunos do espaço rural, o processo de aprendizagem tende a tornar-se internalizado por meio do auxílio do próprio 
aluno. Dessa forma, torna-se mais fácil ao educador determinar a atividade didática mais adequada. Todas essas questões contribuem para incrementar uma percepção crítica da realidade socioeducativa e cultural, que passa a ser o ponto de partida do ato de planejar a ação didática.

Para fortalecer o contexto da cidadania dos alunos das escolas do campo supracitadas, a ação pedagógica proposta viabilizou aos estudantes uma vivência prática no exercício da cidadania, por meio, primeiramente, do diagnóstico da sua realidade junto à escola e à família. Num segundo momento, a exposição das problemáticas levantadas ocorreu mediante a fala dos alunos em um espaço público de diálogo e reinvindicação, na Câmara de Vereadores de Cachoeira do Sul.

A interpolação entre a escola e as famílias no diagnóstico das necessidades de cada localidade permitiu uma aproximação dos reais sujeitos, a identificação de uma identidade comum, na luta por direitos, e a representatividade na esfera de poder público municipal. A partir da realidade vivenciada pelos alunos, foram trabalhadas as questóes relacionadas à cidadania, democracia, direitos e deveres e à necessidade do entendimento destes para o empoderamento do estudante e do homem do campo.

O resultado esperado foi alcançado, tendo em vista a plena participação dos estudantes no diálogo junto aos familiares e na escola, no diagnóstico dos problemas da comunidade, na organização da eleição na Câmara de Vereadores do município (votação e escolha dos vereadores mirins) e, por fim, na apresentação das demandas de suas comunidades para todos os presentes.

Acredita-se que a finalidade dessa prática educativa se encontra na preparação das novas gerações para uma intervenção mais ativa, crítica, reflexiva e responsável na esfera dos direitos da sociedade. Em todo esse processo, o maior objetivo está no ato de "pensar para repensar; repensar para agir e agir para transformar” (Rays, 1996, p. 5). Tal método proporciona a ação transformadora mediatizada e temporalizada pela crítica e autocrítica. Esse pode ser o principal instrumento para as atividades de aprendizagem.

Por fim, destaca-se que todas as ações pensadas em prol de uma educação do campo devem perpassar a ideia de uma integração diária e contínua, a qual deve estar integrada às discussões no ambiente escolar, na sala de aula, juntamente ao conteúdo teórico das disciplinas. Essa atitude depende dos sujeitos da escola (professores e funcionários) e da interação com os alunos e seus familiares, bem como do entendimento do cotidiano dos educandos em 
ações teóricas e práticas. Todos os envolvidos no processo educativo devem considerar a educação do campo como direito e como possibilidade da emergência de saberes dos sujeitos do campo.

\section{Referências}

ALMEIDA, J. "Por um novo sentido à prática da agricultura”. In ALTIERI, M. (org.). Agroecologia. Porto Alegre: Editora da UFRGS, 2009. pp. 5-8. ARROYO, M. G. et al. Por uma educação do campo. Petrópolis: Vozes, 2004. BRANDÃO, C. R. "Da escola rural de emergência à escola de ação comunitária”. In ARROYO, M. G. (org.). Da escola carente à escola possivel. 6 ed. São Paulo: Loyola, 2003.

BRASIL. Ministério da Educação. Lei n. 9 9394, de 20 de dezembro de 1996. Brasília: Casa Civil, 1996.

. Ministério da Educação. Conselho Nacional de Educação. Diretrizes Operacionais para Educação Básica nas Escolas do Campo. Parecer CNE/CEB n.o 36/2001, aprovado em 4 de dezembro de 2001. Brasília: Ministério da Educação, 2001.

. Ministério da Educação. Grupo Permanente de Trabalho de Educação do Campo. Referência para uma política nacional de Educação do Campo. Caderno de subsídios. Brasília: Ministério da Educação, 2005.

CALDART, R. S. "Pensando a educação dos camponeses". In WIZNIEWSKY, C. R. F et al. (orgs.). Educação, memória e resistência popular na formação social da América Latina. Porto Alegre: Evangraf, 2016, pp. 88-110.

DAYRELL, J. “A escola como espaço sócio-cultural”. In DAYRELL, J. (org.). Múltiplos olhares sobre educação e cultura. Belo Horizonte: Editora UFMG, 1996.

FERNANDES, B. M. “Diretrizes de uma caminhada”. In KOLLING, E. J. et al. (orgs). Educação do Campo: identidade e politicas públicas. Brasília: UnB, 2002, v. 4, pp. 76-82.

FREIRE, P. Pedagogia do oprimido. Rio de Janeiro: Paz e Terra, 1988. 
. Pedagogia da autonomia: saberes necessários à prática educativa. Rio de Janeiro: Paz e Terra, 1997.

GIL, A. C. Como elaborar projetos de pesquisa. 3 ed. São Paulo: Atlas, 1991.

GODOY, A. S. "Introdução à pesquisa qualitativa e suas possibilidades”. Revista de Administração de Empresas, v. 35, n. 2, pp. 57-63, São Paulo, mar.-abr. 1995. Disponível em: www.scielo.br/scielo.php?script=sci_arttext\&pid=S0034-75901995000200008. Acesso em: 6 mai. 2017.

LEITE, S. C. Escola rural: urbanização e politicas educacionais. São Paulo: Cortez, 1999.

RAYS, O. A. "Planejamento do ensino: um ato político-pedagógico". Espaço Pedagógico, v. 3, n. 1, Passo Fundo, 1996. Disponível em: https:/goo. $\mathrm{gl} / 22 \mathrm{~K} s \mathrm{fG}$. Acesso: 23 maio 2013.

SILVA, R. H. D. da. "Diretrizes educacionais para a Educação Básica nas Escolas do Campo: uma leitura comparativa a partir da temática da educação escolar indígena”. In KOLLING, E. J. et al. (orgs.). Educação do Campo: identidade e politicas públicas. Brasília: Articulação Nacional por uma Educação do Campo, 2002, n. 4, pp. 61-70.

SILVA JÚNIOR, A. F. e BORGES NETTO, M. "Por uma educação do campo: percursos históricos e possibilidades”. Entrelaçando,v. 2, n. 3, pp. 45-60, nov. 2011. Disponível em: www2.ufrb.edu.br/revistaentrelacando/component/phocadownload/category/119?. Acesso em: 5 mai. 2017.

SOUZA, M. A. "Educação do Campo: desafios para as escolas públicas”. In WIZNIEWSKY, C. R. F. et al. (orgs.). Educação, memória e resistência popular na formação social da América Latina. Porto Alegre: Evangraf, 2016, pp. 111-36. 


\section{0 ensino de História e a formação continuada de docentes da educação básica}

Dante Luis Vartha

Diovane Dill

Este capítulo não tem a pretensão de apresentar soluções definitivas para os problemas relacionados ao ensino de História nas séries iniciais e nem mostrar um caminho consensual para que tal atividade se concretize com êxito na prática. O objetivo aqui é trazer à tona algumas reflexões a respeito do ensino de História nas séries iniciais do ensino fundamental e a formação continuada nas escolas da rede pública, observadas nestes quase 15 anos de profissão docente.

Tem-se percebido um aumento de produções acadêmicas relacionados ao ensino de História nas séries iniciais do ensino fundamental. Nesses trabalhos, de um lado são apontados aspectos que contribuem para que o ensino de História não se concretize nas escolas nos primeiros anos desta modalidade de ensino. ${ }^{1}$ Entre as causas mais citadas, estão: a falta de formação específica, a importância das avaliações externas para a Língua Portuguesa e Matemática, além do não gostar da disciplina e de conteúdos de história, questão muito vinculada às experiências docentes como aluno ou à falta de uma formação específica para tal durante a formação inicial.

De outro lado, encontramos trabalhos na área enfatizando novas abordagens, metodologias de trabalho com fontes, imagens e outros recursos, trazendo possibilidades de aplicação em sala de aula. ${ }^{2}$

\footnotetext{
${ }^{1} \mathrm{O}$ trabalho de pesquisa de Miranda (2007) traz à tona estas questões, que, em maior ou menor grau, fazem parte do cotidiano de várias escolas.

${ }^{2}$ Entre os exemplos, podemos citar Almeida (2012) e Bernardo (2009).
} 
Mesmo diante dessa plêiade de possibilidades, o desafio continua podendo ser expresso na falta de uma formação da consciência histórica de nossos alunos, o que acaba por gerar um contingente de adolescentes e jovens que não são capazes de pensar a historicidade dos fatos e fenômenos, corroborando-se com a ausência de uma postura crítica perante a sua condição de sujeito e/ou de suas próprias condições de vida.

A postura anteriormente descrita, recorrentemente presente nos estudos de Cultura Juvenil, ${ }^{3}$ pode acarretar a uma comunidade um caso "paradigmático de amnésia, ou de um tipo de valorização social do esquecimento que provoca inevitáveis perturbações no processo de construção da identidade coletiva" (Miranda, 2007, p. 111).

Nesse sentido, é oportuno referir Rüsen, para quem: "A consciência histórica é a realidade a partir da qual se pode entender o que a história é, como ciência, e por que ela é necessária". O referido autor segue enfatizando "a soma das operações mentais com as quais os homens interpretam sua experiência da evolução temporal de seu mundo e de si mesmos, de forma tal que possam orientar, intencionalmente, sua vida prática no tempo" (Rüsen, 2001, pp. 56-7).

Os Parâmetros Curriculares Nacionais ( $\mathrm{PCN})$ de História já contemplam o ensino dessa disciplina nas séries iniciais do ensino fundamental desde o ano de 1997, tendo como parte de suas orientações:

O ensino e a aprendizagem da História estão voltados, inicialmente, para atividades em que os alunos possam compreender as semelhanças e as diferenças, as permanências e as transformações no modo de vida social, cultural e econômico de sua localidade, no presente e no passado, mediante a leitura de diferentes obras humanas (Brasil, 1997, p. 49).

O referido documento segue afirmando que

Prevalecem estudos comparativos, distinguindo semelhanças e diferenças, permanências e transformações de costumes, modalidades de tra-

\footnotetext{
${ }^{3}$ A título de informação, apontamos algumas obras: ABRAMO, H. e BRANCO, P. P. M. (orgs.). Retratos da juventude brasileira: análises de uma pesquisa nacional. São Paulo: Ed. Fundação Perseu Abramo, 2005; ABRAMO, H. Cenas juvenis: punkes e darks no espetáculo urbano. São Paulo: ANPOCS, 1994; ABRAMO, H. et al. (orgs.) Juventude em debate. São Paulo: Cortez, 2000.
} 
balho, divisão de tarefas, organizações do grupo familiar e formas de relacionamento com a natureza. A preocupação com os estudos de história local é a de que os alunos ampliem a capacidade de observar o seu entorno para a compreensão de relações sociais e econômicas existentes no seu próprio tempo e reconheçam a presença de outros tempos no seu dia-a-dia (Brasil, 1997, p. 51).

Ainda assim, em grande parte das escolas, o ensino de História nas séries iniciais fica relegado a efemérides e rememorações de datas comemorativas, dentro de uma visão eminentemente cultural ou nacional ufanista.

Nesse contexto, é de suma importância a formação inicial ${ }^{4} /$ continuada dos docentes responsáveis por esse nível de ensino, predominantemente dos egressos dos cursos de pedagogia responsáveis por esse conteúdo/disciplina nas séries iniciais do nível fundamental.

Como um elemento complexificador desse cenário, devemos salientar ainda a atuação de docentes egressos do ensino médio/magistério. Boa parte desses profissionais se formou em um período em que não havia a preocupação com uma formação específica para o ensino de História. Cabe salientar que, nesse contexto, a formação continuada ganha relevo e que, mesmo na formação inicial, os currículos dos cursos de pedagogia já contemplam conhecimentos históricos e historiográficos, e várias instituições de ensino superior que oferecem o curso já disponibilizam disciplinas sobre metodologia do ensino de História e/ou história do Rio Grande do Sul ou similares.

Também são muitos os professores que não se sentem preparados para lecionar essa matéria, e nos perguntamos: por que nos espaços de formação continuada nas escolas não se trabalha esse tema com os professores? E nas chamadas reuniões pedagógicas, como a questão aparece?

\footnotetext{
${ }^{4} \mathrm{~A}$ formação inicial é o momento da preparação formal de futuros professores numa instituição específica, propiciando-lhes aquisição de conhecimentos pedagógicos e disciplinares, ou seja, conceitos teórico-práticos. Sobre essa questão, Mercado (1999, p. 100) salienta que "formação inicial é a que predomina e se dá em universidades em cursos de graduação ou pós-graduação. Nesta formação se destaca o papel do professor como especialista em uma ou várias áreas disciplinares, sendo o domínio de conteúdos o objetivo fundamental da formação inicial do professor. A formação de professores se converte em processo de transmissão de conhecimentos científicos e culturais para dotar os professores de uma formação especializada, centrada principalmente no domínio dos conceitos e estrutura disciplinar da matéria que é especialista”.
} 
Nesse cenário, a temática da formação continuada estabelecida em nosso ordenamento jurídico, prioritariamente de natureza educacional, implica a necessidade premente da qualificação profissional, além da formação adquirida nos cursos de graduação. ${ }^{5}$

Nas últimas décadas, em face da crescentes transformações do mundo do trabalho, inúmeros estudos se preocupam com o impacto dessas mudanças e sua relação com a formação de profissionais para atender a uma nova ordem social. Essas pesquisas têm demonstrado o crescimento expressivo da valorização do domínio técnico nos mais diversos campos profissionais. No que se refere à formação de professores, essa valorização tem causado alterações profundas nas análises sobre a constituição de uma identidade profissional.

O art. 67 da Lei 9.394/96 enfatiza a necessária valorização dos profissionais da educação, salientando que:

Os sistemas de ensino promoverão a valorização dos profissionais da educação, assegurando-lhes, inclusive nos termos dos estatutos e dos planos de carreira do magistério público:

I - ingresso exclusivamente por concurso público de provas e títulos;

II - aperfeiçoamento profissional continuado, inclusive com licenciamento periódico remunerado para esse fim;

III - piso salarial profissional;

IV - progressão funcional baseada na titulação ou habilitação, e na avaliação do desempenho;

V - período reservado a estudos, planejamento e avaliação, incluído na carga de trabalho;

VI - condições adequadas de trabalho. Parágrafo único. A experiência docente é pré-requisito para o exercício profissional de quaisquer outras funções de magistério, nos termos das normas de cada sistema de ensino (Brasil, 1996).

\footnotetext{
${ }^{5}$ LDBs (Leis de Diretrizes e Bases da Educação Nacional) n. $.^{\circ} 4.024 / 61$, n. ${ }^{\circ}$ 5.540/68, n. ${ }^{\circ}$ 5.692/71, n. ${ }^{\circ}$ 7.044/82 e n. ${ }^{0}$ 9.394/96, em documentos do Fundef (Fundo de Manutenção e Desenvolvimento do Ensino Fundamental e de Valorização do Magistério), da Anfope (Associação Nacional pela Formação dos Profissionais de Educação), nas resoluções do CNE (Conselho Nacional de Educação): CP n. ${ }^{\circ}$ 1, que institui as Diretrizes Curriculares Nacionais para a Formação de Professores da Educação Básica e CP n. ${ }^{\circ} 2$, que institui a duração e a carga horária dos Cursos de Licenciatura.
} 
A formação continuada também pode ser entendida como a "busca de alternativas às modalidades hegemonicamente propostas pelos sistemas de ensino, em especial com vistas à 'capacitação' ou 'aperfeiçoamento' dos docentes” (Garcia e Schmidt, 2010, p. 56).

Destacando-se, ainda, que essa

Apresenta-se como sendo uma condição imprescindível para o desenvolvimento das competências, habilidades e saberes adquiridos durante a formação inicial, mas também representa um espaço de construção e reconstrução de novos conhecimentos e práticas pedagógicas, implicando em alterações na organização, nos conteúdos, nas estratégias, recursos, refletindo-se positivamente nas relações sociais estabelecidas entre equipes pedagógicas, docentes e alunos (Cabral e Medeiros, 2006).

Para Francisco Imbernón (2011, pp. 50-1), ${ }^{6}$ uma formação permanente é constituída de cinco grandes eixos, quais sejam:

A reflexão prático teórica sobre a própria prática mediante a análise, a compreensão, a interpretação e a intervenção sobre a realidade. [...] A troca de experiências entre iguais para tornar possível a atualização em todos os campos de intervenção educativa e aumentar a comunicação entre os professores. A união da formação a um projeto de trabalho. A formação como estímulo crítico ante práticas profissionais como a hierarquia, o sexismo, a proletarização, o individualismo, o pouco prestígio etc., e práticas sociais como a exclusão, a intolerância etc. $\mathrm{O}$ desenvolvimento profissional da instituição educativa mediante o trabalho conjunto para transformar essa prática $[. .$.$] .$

Mesmo diante de um conjunto de políticas orientando a formação continuada, cabe destacar que, no contexto de atuação dos autores, esses pressupostos ainda soam como utopia, tendo em vista as condiçóes e/ou estrutura das escolas e de trabalho dos professores.

${ }^{6}$ Sobre o assunto, pode ser consultado também: IMBERNÓN, F. Formação permanente do professorado: novas tendências. São Paulo: Cortez, 2009. 
Parte expressiva dos docentes que participarão da pesquisa dos autores informa, em pesquisa piloto, que tal formação continuada não ocorre nas escolas de forma adequada, respondendo ou procurando responder às necessidades do local ou às lacunas que se criaram. Podem ser observados alguns motivos pelos quais isso ocorre. Nossas investigações sinalizam para as questões que abaixo seguem.

Inicialmente, as escolas, principalmente as de menor porte e/ou localizadas na periferia ou em bairros afastados, não possuem recursos suficientes para trazer teóricos ou estudiosos com efetivo domínio de conteúdos, fazendo com que a formação continuada nas escolas seja como um conjunto de reflexões pautadas, na maioria das vezes, pelo senso comum, com pouca contribuição à prática dos professores, sendo bastante frequentes atividades de autoajuda que, apesar de serem importantes, não enfrentam efetivamente lacunas formativas dos docentes dessas redes, visto que pouco contribuem com a prática e a reflexão da prática docente.

Além disso, quando a gestão viabiliza essa formação, nem sempre tem autonomia para decidir acerca da temática a ser tratada, visto que o tema muitas vezes é dado pelo formador, não adentrando nas especificidades das áreas. Não é incomum o total desconhecimento do formador da realidade daquela escola, nesse sentido, em relação às temáticas específicas, como o ensino de História nas séries iniciais, que dificilmente são trabalhadas.

Como terceiro elemento, nossas pesquisas de campo indicam que os docentes estão mais preocupados com questões de ordem metodológicas. Eles afirmam que sabem o que deve ser feito, demandando orientações do que fazer, requerendo também exemplos práticos. Nesse sentido, a sequência das pesquisas que resultarão em nossas dissertações, obviamente, aprofundará essa temática, que, até o momento, nos parece equivocada, visto que a apropriação rigorosa de discussões históricas e historiográficas aparenta ser lacunosa, o que atribuímos à formação inicial desses docentes.

Combinado a esse terceiro elemento, encontramos referência à fragmentação da formação continuada, visto que não existe, nos contextos estudados, continuidade desta, nem no que tange às temáticas quanto às possibilidades metodológicas, havendo uma descontinuidade nessa formação. Esse fato pode ser justificado pela necessidade de o poder público contratar esses formadores, tomando como referência os menores orçamentos, evidenciando que a política de formação continuada de professores é tratada, quando muito, como política de governo e não de Estado, como a lei preconiza. 
Nesse sentido, a Formação Continuada depende significativamente do poder público, no sentido de propiciar formações de qualidade às escolas públicas ou correr o risco de não realizar um bom trabalho, desqualificando ainda mais o trabalho docente. "Em tempos marcados por grandes apologias dos processos avaliativos. Há mais coisas em seus subterrâneos que não podem ser ignoradas, sobretudo por parte dos gestores das políticas públicas" (Miranda, 2007, p. 207).

No atual momento brasileiro, a temática da formação continuada de professores de História é acrescida da incerteza epistemológica acerca da validação curricular de conhecimentos históricos, diante das reformulações educacionais do ensino médio, por meio das quais as áreas das ciências humanas e sociais vêm sofrendo um desprestígio.

A função precípua da História é identificar e compreender a historicidade do presente, contribuindo para a construção da identidade e possibilitando a construção da noção de semelhança, diferença, desigualdade, transformações e permanências. Ademais, como assevera o texto contido nos PCN:

nas últimas décadas, passaram a ser difundidas percepções diferentes do processo de aprendizagem, do papel que os materiais didáticos desempenham, dos instrumentos e significados das avaliações e das funções sociais e culturais atribuídas à escola e ao professor. Essas novas percepções, hoje desenvolvidas por docentes e pesquisadores, têm levado a reflexões profundas quanto à interação entre teoria e prática no espaço escolar e às relações estabelecidas entre o currículo formal elaborado por especialistas e instituições e o currículo real que, efetivamente, se concretiza na escola e na sala de aula (1997, p. 28).

Mesmo diante desse contexto, a demanda por formação continuada, pensada de forma articulada, mas que dê conta das especificidades dos diferentes campos de conhecimento, com a devida articulação metodológica, também é uma realidade.

Nas últimas décadas, por diferentes razões, nota-se uma crescente preocupação dos professores do ensino fundamental em acompanhar e participar do debate historiográfico, criando aproximações entre o conhecimento histórico e o saber histórico escolar. Reconhece-se que o 
conhecimento científico tem seus objetivos sociais e é reelaborado, de diversas maneiras, para o conjunto da sociedade. Na escola, ele adquire, ainda, uma relevância específica quando é recriado para fins didáticos (PCN, 1997, p. 30).

Cabe salientar ainda que os dados sistematizados até o momento indicam que poucas vezes o professor é questionado sobre as suas demandas para a formação continuada, sendo sua trajetória docente e sua percepção dos limites e possibilidades do conhecimento, prioritariamente do conhecimento histórico, negligenciada e desqualificada, negando-se o exercício da pesquisa por parte desse profissional.

Ainda no sentido de complexificar a discussão, devemos referir debates acerca da pertinência do ensino de História para as series iniciais, visto ser muito comum professores que afirmam que: "aluno tem que sair lendo e escrevendo do 5. ${ }^{\circ}$ ano, depois tem o professor de História”. Nesse sentido, "frente a pergunta de muitos professores - se é possível ensinar história antes de alfabetizar (leitura e escrita) - respondo com outra pergunta: é possível alfabetizar sem História?” (Fonseca, 2009, p. 8).

Refutando a assertiva de alguns professores que privilegiam a leitura e a escrita nas séries iniciais do ensino fundamental, destacamos a necessária viabilização por parte dos docentes da denominada "alfabetização histórica", de tal forma a colaborar com o professor da área, possibilitando a compreensão, ainda que rudimentar, de categorias centrais para a apropriação do conhecimento histórico, uma vez que "as séries iniciais do ensino fundamental são momentos únicos que assinalam a iniciação da criança em um novo mundo. Em linhas gerais: o trabalho com o conhecimento histórico é de extrema relevância, pois se trata de inserir a criança no mundo do saber histórico e social" (Oliveira, 2011, p. 25).

Sobre a necessidade e adequação da "alfabetização histórica", referimo-nos à questão da denominada "educação histórica", proposta por Jörn Rüsen, Peter Lee, Isabel Barca e Maria Auxiliadora Schmidt, entre outros, para quem se faz necessário potencializar o desenvolvimento do pensamento histórico e a formação da consciência histórica entre crianças e jovens.

Não vemos problemas em trabalhar a História nas séries iniciais juntamente com as linguagens, ou será que o aluno, ao estudar História, não aprende a ler? Não teria um olhar mais aguçado para o seu mundo (casa, rua, bairro, cidade, estado, etc.)? Não aumentaria sua habilidade de escrever, por 
exemplo, ao comparar duas fotos de seu bairro? Como eram as ruas? Como as pessoas se vestiam? Que construções surgiram? Isso depende de um trabalho? Que tipo de trabalho? Para quem este trabalho é realizado? Ou seja, não teriam uma capacidade de interpretação maior?

Tentando dar conta dessa necessidade, utilizamos o conceito de "literacia histórica”, que prima pela apreensão por meio da narrativa do movimento histórico, atribuindo significado ao tempo.

Reforçando nossas assertivas, destacamos que entre os objetivos dos PCN para o primeiro e segundo ciclos constam: "Reconhecer algumas semelhanças e diferenças sociais, econômicas e culturais, de dimensão cotidiana, existentes no seu grupo de convívio escolar e na sua localidade". Ou ainda "reconhecer algumas permanências e transformações sociais, econômicas e culturais nas vivências cotidianas das famílias, da escola e da coletividade, no tempo, no mesmo espaço de convivência” (Brasil, 1997, p. 50), apontando expressamente a necessidade de propiciar condições para "estabelecer relações entre o presente e o passado" (Brasil, 1997, p. 51).

Então, por que o argumento de ter de se concentrar em português para ler e escrever? É inegável que a língua portuguesa seja importante e não possa em hipótese alguma ser relegada a um segundo plano, mas não é argumento para deixar de trabalhar a História.

O estímulo à educação histórica que viabiliza a alfabetização histórica nas séries iniciais dá início ao processo de conhecimento histórico, materializado nas séries finais do fundamental e no ensino médio.

Destacamos ainda que nesse momento, isto é, nas séries iniciais, a temporalidade não é o mais importante, mas o reconhecimento da passagem do tempo, de mudança, de permanência, de diferenças e semelhanças, conceitos que começam a ser trabalhados de forma simples, porém que podem trazer uma grande no restante da educação básica.

O segundo ponto a respeito dessa fala é que "depois tem o professor de história”. Sim, inegavelmente, nas séries finais, teremos docentes com formação específica. Entretanto, diante de uma alfabetização histórica precoce, o trabalho desses docentes e a compreensão dos discentes serão potencializados.

Nesse contexto, retomamos o argumento do papel passível de ser desempenhado pela formação continuada, tanto para docentes com formação em História, quanto para docentes sem essa formação, mas que são responsáveis pela sistematização e socialização da denominada educação histórica. 
Por óbvio, devemos apontar ainda que o professor-estudante-pesquisador, preocupado em melhorar sua prática, deve entender que exemplos e modelos devem ser adaptados à sua realidade escolar e, por muitas vezes, servir como inspiração. Nesse sentido, as teorias pedagógicas, atividades preparadas com antecedência, ideias, são ferramentas que não podem ser úteis todos os dias, porém, em determinados contextos podem auxiliar o trabalho docente.

O terceiro ponto de reflexão sobre o ensino de História nas séries iniciais refere-se ao esforço da equipe diretiva no sentido de estimular inovações, propiciando espaços de discussão prioritariamente entre docentes recém-formados e docentes mais experientes, de tal sorte a equilibrar sua atuação, contribuindo para a consolidação de uma cultura escolar efetivamente participativa, inovadora e emancipatória.

O quarto ponto de reflexão é relativo à carga de trabalho do professor e o acesso às instituições de ensino superior após sua formação. Mesmo com várias possibilidades formativas, disponibilizadas por ações governamentais ou políticas de instituições privadas, sejam de extensão, de pós-graduação ou outras ações, o professor não consegue dar continuidade à sua formação devido às condições de precarização de suas condições de trabalho ultrajantes no Brasil, visto não ser incomum professores que trabalham até 60 horas semanais, dividindo-se, muitas vezes, em duas ou três escolas, em diferentes redes de ensino (municipal, estadual e/ou privada), contexto em que investimentos na formação que não sejam obrigatórios são de difícil operacionalização, o que atribui mais importância à formação continuada disponibilizada pelos sistemas de ensino, muitas vezes a única oportunidade formativa desses profissionais.

\section{Considerações finais}

Ainda que este artigo resulte de estudos ainda em curso, as questões aqui apresentadas, formação continuada de professores e ensino de História nas séries iniciais do ensino fundamental, são de suma importância, não somente para esses docentes, mas para uma compreensão histórica disponibilizada pela educação básica, realmente comprometida com a constituição de sujeitos que sejam capazes de compreender a trajetória da sociedade, sua gênese e transformação, as inúmeras variáveis que nela intervêm, resultantes da ação humana, de tal sorte a compreender-se como agentes capazes de viabilizar transformações sociais. 
No contexto em que vivemos, momento de rápidas e intensas transformações, a formação continuada de docentes em exercício pode contribuir para a efetivação desse propósito, de sorte a ampliar os conhecimentos sobre as problemáticas contemporâneas presentes no espaço escolar, e romper com o distanciamento histórico entre conhecimentos históricos produzidos na academia e conhecimentos históricos passíveis de serem escolarizados.

\section{Referências}

ALMEIDA, V. L. et al. História. Org. Márcio Rogério de Oliveira Cano. São Paulo: Blucher, 2012, v. 6.

BERNA RDO, S. B. R. O ensino de história nos primeiros anos do ensino fundamental: o uso de fontes (dissertação). UEL, 2009.

BRASIL. Ministério da Educação e Cultura. Lei de Diretrizes e Bases para a Educação Nacional n. 9.394/96. Brasília: MEC/FAE, 1996.

CABRAL, C. L. O. e MEDEIROS, M. V. "Formação docente: da teoria à prática, em uma abordagem sócio-histórica”. E-Curriculum, v.1, n.2 São Paulo, 2006.

FONSECA, Selva Guimarães. Fazer e ensinar história. Belo Horizonte: Dimensão, 2009.

GARCIA, T. M. A. e SCHMIDT, M. A. "Formação continuada de professores: a experiência do grupo de Araucária”. In HAGEMEYER, R. C. C. Formação docente e contemporaneidade: referenciais e interfaces da pesquisa na relação universidade-escola. Curitiba: Editora. UFPR, 2010.

IMBERNÓN, F. Formação permanente do professorado: novas tendências. Trad. Sandra Trabucco Valenzuela. 1 ed. São Paulo: Cortez, 2009. . Formação docente e profissional: formar-se para a mudança e a incerteza. Trad. Silvana Cobucci Leite. 9 ed. São Paulo: Cortez, 2011.

MERCADO, L. P. L. Formação continuada de professores e novas tecnologias. Maceió: EDUFAL, 1999.

MIRANDA, S. R. Sob o signo da memória: cultura escolar, saberes docentes e história ensinada. São Paulo: Editora UNESP; Juiz de Fora: Editora UFJF, 2007. 
OLIVEIRA. Sandra Regina Ferreira de. "A progressão do conhecimento histórico na escola”. In FONSECA, Selva Guimarães e JUNIOR, Décio Gatti (orgs.). Perspectivas do Ensino de História: ensino, cidadania e consciência histórica. Uberlândia: EDUFU, 2011.

PARÂMETROS CURRICULARES NACIONAIS. História e Geografia. Secretaria de Educação Fundamental. Brasília: MEC/SEF, 1997.

RÜSEN, J. Razão histórica - Teoria da história: os fundamentos da ciência histórica. Trad. Estevão de Rezende Martins. Brasília: Editora da UnB, 2001. 


\section{Formação continuada de professores indígenas}

Hellen Cristina de Souza Eliane Boroponepá Monzilar

O presente artigo apresenta uma discussão bastante preliminar a respeito do projeto de formação continuada de professores desenvolvido na Escola Estadual Indígena Jula Paré, do povo indígena umutina, habitante da região sudoeste do estado de Mato Grosso. Procura mostrar aspectos que podem ser considerados inovadores nesse projeto, que foi realizado na escola entre 2009 e 2015. Toma como ponto de partida a noção de que o projeto de educação escolar dos umutinas está pensado e se organiza para construir e ampliar as recentes conquistas dos povos indígenas no contexto de políticas educacionais, avançando, a duras penas, sobre um percurso histórico destrutivo das especificidades culturais e da autonomia política dos povos indígenas.

$\mathrm{O}$ conjunto de dados apresentados procura demonstrar que a formação continuada dos professores se submeteu às demandas específicas do projeto de educação escolar entre os umutinas, que inclui, entre outros eixos, o fortalecimento do ensino de Português e Matemática, a busca pela proficiência em Química no Ensino Médio, a ampliação do acesso ao cursos de graduação e pós-graduação, a valorização de uma perspectiva dialógica entre os saberes do povo umutina e o projeto de educação científica, tomando a escola como um lugar de referência política e cultural nesse diálogo.

No Brasil, as respostas às determinações legais que orientam a formação continuada de professores criaram alternativas e possibilidades para responder a uma demanda por formação que pode apresentar características distintas nas diversas regiões do país. No sistema de educação do estado de Mato Grosso, a formação continuada para professores se estabelece a partir das ações do Centro de Formação e Aperfeiçoamento de Professores da Educa- 
ção Básica - Cefapro. Esses centros de formação fazem parte da estrutura da Secretaria de Estado de Educação de Mato Grosso - Seduc/MT - e estão subordinados à Superintendência de Formação de Profissionais da Educação Básica, - SUFP.

Os Cefapros são responsáveis pela implantação das políticas de formação continuada do sistema estadual de educação e foram criados a partir de 1997, com a concepção de trabalho em rede (Decreto 2.007/1997). As orientações legais, bem como as orientações para a implantação dos Centros de Formação Continuada, estão sistematizadas em um texto publicado pela Seduc/MT, em 2010: "Política de Formação dos Profissionais da Educação Básica”. Com a criação dos centros de formação, o governo do estado passou a selecionar, por meio de editais específicos, professores do quadro efetivo da rede estadual. A vagas foram abertas para a atuação por disciplina e por modalidade, e nos polos onde havia escolas indígenas foram criadas vagas específicas para professor formador da educação escolar indígena, cabendo a este a responsabilidade de acompanhar o projeto de formação continuada dos profissionais das escolas indígenas.

No estado, atualmente, funcionam 15 centros de formação. O polo do Cefapro, que tem sede em Tangará da Serra, acompanha o projeto de formação continuada das escolas de educação básica, do sistema estadual de educação, localizadas nos municípios de Tangará da Serra, Campo Novo do Parecis, Sapezal, Denize, Nova Olímpia, Porto Estrela e Barra do Bugres, onde se localiza a Terra Indígena Umutina e a Escola Estadual Indígena Jula Paré.

Até 2015, as unidades escolares da rede estadual deveriam organizar sua proposta de formação continuada em torno do Projeto Sala de Educador. Nesse contexto da política de formação continuada, o principal objetivo era a melhoria da qualidade da educação, tomando a unidade escolar como o locus e foco da formação:

O Projeto Sala do Educador, como Política de Formação dos profissionais da educação do Estado de Mato Grosso, aponta para um processo de formação que preconiza partilhar, discutir e refletir sobre as ações educativas, e para um objetivo principal de fortalecer a escola como espaço formativo com o comprometimento coletivo na busca da superação das fragilidades e conseqüente construção das aprendizagens (Parecer Orientativo n. ${ }^{\circ} 01 / 2014$, p. 3). 
As orientações sobre a organização do Projeto Sala de Educador eram encaminhadas anualmente pela Superintendência de Formação, cabendo aos Cefapros e aos professores formadores os encaminhamentos para as unidades escolares. Em 2016, a Portaria 161/2016, publicada no Diário Oficial do Estado, instituiu a criação do Núcleo de Desenvolvimento Profissional na Escola (NDPE) e, no contex to desse núcleo, o Projeto de Estudos e Intervenção Pedagógica (PEIP), focado na formação docente, e o Projeto de Formação Contínua dos Profissionais Técnicos e Apoio Administrativos Educacionais (Proftaae).

Os dados analisados nessa comunicação se referem aos anos de 2009 a 2015 e, portanto, foram organizados em torno das discussões do Sala de Educador, conforme orientação da Superintendência de Formação naquele período. Além do Projeto Sala de Educador, anualmente encaminhado ao polo do Cefapro, em Tangará da Serra, Mato Grosso, esta comunicação busca também analisar projetos e parcerias decorrentes de demandas específicas do povo umutina, formuladas e encaminhadas ao centro de formação no contexto do projeto de formação continuada da Escola Estadual Indígena Jula Paré, na Terra Indígena Umutina.

Os umutinas são um povo indígena que se autodenomina balotiponê e são habitantes tradicionais da região central do Brasil. $\mathrm{O}$ atual território umutina tem o formato de uma ilha fluvial, por onde se distribuem três aldeias a $15 \mathrm{~km}$ da sede do município ${ }^{1}$ de Barra do Bugres, em Mato Grosso. à direita da terra umutina, o seu limite é Rio Xopô (Bugres), e à esquerda o Rio Laripô (Paraguai).

O povo umutina sofreu um dos mais violentos processos de contato da história recente do Brasil - em menos de um século, passaram de uma população indígena isolada a uma população considerada extinta (Ribeiro, 1986, p. 269). O clássico tex to de Harold Schultz, intitulado 23 resistem à civilização, narra o encontro do etnólogo com os sobreviventes umutinas na primei-

\footnotetext{
${ }^{1}$ A discussão sobre o projeto de formação continuada dos umutinas, tal como aparece neste texto, compõe, atualmente, o Banco de Experiências Exitosas do Programa de Apoio ao Setor Educacional do Mercosul (PASEM). Tendo concorrido a 2. ${ }^{a}$ Edição do Prêmio Paulo Freire, em 2014, com o título "Políticas de Formação Continuada e Educação Escolar Indígena na Rede Estadual de Ensino em Mato Grosso/Brasil”, proposta apresentada pelos professores Edna Monzilar, Eliane Boroponepá, Eneida Kupodonepá, Jairton Kupodonepá e Osvaldo Monzilar, da Escola Estadual Indígena Jula Paré, e pela professora Hellen Cristina de Souza, do polo do Cefapro em Tangará da Serra.
} 
ra metade do século XX, mesmo período em que o Serviço de Proteção ao Índio(SPI), constrói nas terras umutinas um Posto de Fraternidade Indígena e para lá transfere famílias de diferentes povos indígenas - paresí, nambikwara, bakairi, irantxe boróro e cayabi - como parte das políticas protecionistas marcadas por um ideário fortemente integracionista, que orientou a ação governamental voltada aos povos indígenas nos primeiros anos da República.

Atualmente, vivem na aldeia central umutina, que cresce ao lado das antigas construções do Posto de Fraternidade Indígena, cerca de 500 habitantes umutinas descendentes dos oito povos que foram levados para a área pelo SPI e que, conforme contam os mais velhos, ajudaram os umutinas a se reconstruírem como povo. Nos útlimos anos, os umutinas também registram como significativa a presença dos chiquitanos e terenas.

A língua falada pelos umutinas pertenceu ao tronco linguístico Macro-Jê, da família bororo, e atualmente é considerada uma língua extinta; no entanto, sobrevive na aldeia e no projeto de educação escolar um vigoroso e exitoso processo de revitalização linguística. Ainda que concebam uma aldeia multiétnica na sua origem, os atuais umutinas a organizam a partir de um complexo e emaranhado discurso de revitalização étnica e revitalização da língua a partir do referencial histórico e cultural do povo umutina, como é possível ler nos trabalhos recentes produzidos sobre eles e por eles.

A oferta dos primeiros anos da Educação Básica está vinculada ao município de Barra do Bugres, enquanto os anos finais e o Ensino Médio estão vinculados ao sistema estadual de educação em Mato Grosso. Essa comunicação refere-se ao projeto de formação continuada dos profissionais da Educação Básica que trabalham na Escola Estadual Indígena Jula Paré na aldeia central umutina. É possível afirmar que a escola é um local de referência de organização política de toda a comunidade umutina. Nela, são discutidos os problemas de políticas internas, de rituais culturais e também a importância do conhecimento escolar para o povo umutina como uma arma de revitalização dos rituais quase em desuso ou adormecido (Sala de Educador, 2013).

Foi também no contexto da escola que as famílias umutinas deram forma aos processos de organização e ressignificação cultural promovidos desde a perspectiva do povo umutina, que orientou a construção da noção de aldeia multiétnica ou multicultural. A comunidade e os professores estão buscando desde a escola a ressignificação e a revitalização da cultura, partindo principalmente do projeto de revitalização da língua materna e da promoção da prática da cultura original dos umutinas. 
Uma das metas da proposta do projeto de formação continuada, que se formulou a partir de 2009, na Escola Jula Paré, foi submeter a proposta de formação continuada aos objetivos que a escola e a comunidade estavam dando ao projeto mais amplo de educação escolar que se desenvolvia na escola, tendo como referência as demandas da comunidade. É possível afirmar que a decisão de subordinar o projeto formativo às demandas da comunidade é uma marca importante do povo umutina, que se atualiza nos espaços formativos da Escola Umutina. Tal proposta se lê tanto no projeto político-pedagógico da escola quanto nos documentos e demandas dos estudantes, dos professores e da comunidade:
[...] atender as necessidades e criar condições para que o povo Indígena Umutina continue a lutar pela sobrevivência étnica e cultural proporcio- nando-lhe melhor qualidade de vida, através de ações na área de educa- ção, proporcionando alternativas, para geração de renda familiar, com aproveitamento dos recursos existente na Terra Indígena Umutina (Sala de Educador, 2013, p. 4).

O objetivo do projeto de formação continuada proposto pelos umutinas revela o modo como o povo está dando à escola um papel importante nos processos de sobrevivência. As ações da formação continuada, do mesmo modo que o projeto mais amplo de educação escolar se relaciona com os processos de revitalização da língua e da cultura, deve estar subordinada à busca dos jovens e dos adultos pela formação profissional e a criação de alternativas para a geração de renda familiar, tendo o território como ponto de partida.

Nesse contexto, a luta por uma educação de qualidade e culturalmente pertinente levou a escola indígena a ser pensada desde a pauta dos direitos humanos e sociais, sendo reconhecidas sua diversidade cultural, as experiências sociopolíticas, linguísticas e a valorização do saber tradicional de cada povo. São com essas referências socioculturais que os umutinas organizam um projeto formativo subordinado à realização de ações político-pedagógicas que resultarão num programa de fortalecimento da educação na comunidade umutina (Sala de Educador, 2014).

Do ponto de vista da formação de professores no contexto específico dos projetos umutinas, foram importantes as contribuições de Porto-Gonçalves e a discussão sobre a colonialidade do saber, no sentido de chamar a atenção para a necessidade de pensar os efeitos do processo colonizador nas constru- 
ções epistemológicas locais. E, embora o autor não esteja tratando do tema da formação docente, suas conclusões abrem uma importante reflexão sobre formação, saberes e práticas docentes:

Para além do legado de desigualdade e injustiça sociais profundos do colonialismo e do imperialismo, já assinalados pela teoria da dependência e outras, há um legado epistemológico do eurocentrismo que nos impede de compreender o mundo a partir do próprio mundo em que vivemos e das epistemes que lhes são próprias (Porto-Gonçalves, 2002, p. 13).

É bastante significativo que o conjunto da obra sobre colonialidades não esteja relacionado à discussão específica sobre os povos indígenas, mas ao conjunto de saberes que se produziu na América. Em distintas esferas educacionais, está se desenvolvendo uma forte compreensão política de que não pode mais sobreviver o tema concreto da colonização e subordinação dos saberes tradicionais ao modelo hegemônico de produção do conhecimento capitaneado pela Ciência Moderna como única possibilidade e destino.

Essa discussão também se desdobrou na seleção dos textos e das práticas pautados no debate sobre a interculturalidade, por meio dos quais se procurou pensar a proposta desde a contribuição de autores indígenas que pudessem apontar para uma dimensão mais dialógica e complementar, como os professores da comunidade estavam apontando. Sendo assim, a discussão sobre interculturalidade a partir de uma possibilidade indígena inspirou-se, principalmente, no trabalho de Gersen Baniwa ao lembrar 'a própria atualização dos mitos de origem que foram readequados para garantir um lugar às sociedades brancas européias no momento da criação das sociedades humanas que não existia, para evitar conflitos e contradições explicativas" (Baniwa, 2010, p. 13). No mesmo texto, o autor ainda lembra que "as cosmologias e as culturas indígenas se pautam pelos princípios de complementariedade e não de exclusão ou divisão" (Baniwa, 2010, p. 13). Essas noções aparecem nos projetos e nos documentos umutinas, tal como neste fragmento do Projeto Sala de Educador, enviado ao Cefapro em 2014:

Ao longo da história, nós povo Umutina elaboramos modos próprio produzir, armazenar, expressar, transmitir, avaliar e reelaborar nossos conhecimentos e concepções sobre o mundo, o homem e sobre natural. 
Os resultados são valores, concepções, práticas e conhecimentos científicos e filosóficos próprios transmitidos e enriquecidos a cada geração. Sabemos que é importante ter e manter o conhecimento tradicional e conhecimento científico da sociedade envolvente e entendemos que somente através da educação, será possível garantir à população indígena o exercício pleno da cidadania e da interculturalidade, o respeito às nossas particularidades linguístico-culturais (Sala de Educador, 2014, p. 5).

O rol de experiências analisadas neste texto procurou demonstrar que a formação de professores pode contribuir para a consolidação de espaços de reflexão e diálogo com força para se movimentarem tanto no sentido de dar visibilidade aos saberes produzidos e socializados desde tempos imemoriais pelos povos indígenas, como para demonstrar os equívocos que a exclusão e a subordinação que a hegemonia da razão moderna, como um discurso colonizador, impôs aos sistemas de educação escolar dos povos indígenas.

Para esta comunicação, tomamos como referência as ações relacionadas à formação para a docência em Química, formação para a docência em ciências humanas e as ações relacionadas à promoção do acesso aos cursos de pós-graduação stricto sensu, conforme segue abaixo.

As primeiras reflexões sobre a formação continuada e a docência em Química para os umutinas partiram de uma demanda comunitária bastante específica dos estudantes umutinas que cursaram ou estavam cursando o Ensino Superior fora dos projetos de formação de professores. A organização do projeto de formação para a docência em Química considerou os aspectos relacionados ao domínio dos conteúdos pelos professores regentes principalmente do Ensino Médio, que solicitavam uma formação específica acerca de conteúdos disciplinares bastante delimitados, tendo em vista, sobretudo, as dificuldades relatadas pelos jovens que haviam acessado os cursos de graduação. O objetivo dessa ação foi fortalecer na escola um conjunto de ações formativas orientadas para o domínio dos conteúdos específicos do campo disciplinar das Ciências da Natureza e dos constituintes específicos do currículo de Química para o Ensino Médio.

As ações formativas aconteceram a partir de uma parceria entre a Escola Estadual Indígena Jula Paré, o Cefapro e o Laboratório de Química do campus da UNEMAT, em Tangará da Serra, com financiamento da Fundação de Amparo a Pesquisa do Estado de Mato Grosso, (Fapemat), que incluiu a compra de um laboratório básico de química. Desde 2013, o Laboratório de 
Pesquisa e Ensino de Química(LabPeq) da Universidade Federal de Mato Grosso tornou-se um parceiro formador, e a experiência se organizou a partir de oficinas que procurassem dar visibilidade à relação que se estabelece entre o conhecimento químico produzido no ocidente e os saberes locais e tradicionais sistematizados e socializados pelos povos indígenas. A busca pela proficiência de conhecimentos químicos entre os umutinas foi capaz de dar visibilidade ao tema dos saberes tradicionais e fortalecer a discussão sobre a educação em contextos multiculturais.

Diferentemente da proposta formativa para a docência em Química, cuja demanda partiu dos estudantes umutinas, o foco principal da formação continuada intercultural para a docência em Ciências Sociais tratou especificamente de contribuir com o debate sobre a formação continuada de professores indígenas, camponeses e quilombolas, de modo a estimular a reflexão e a exploração de epistemologias alternativas ao modelo hegemônico da organização dos saberes nos conteúdos específicos do campo disciplinário das ciências humanas.

O projeto foi estruturado para um curso de 60 horas durante o período letivo de 2014 e tomou como referência teóricos como Minolo, Quijano e, no Brasil, Porto-Gonçalves e Emerson, entre outros. O objetivo foi elaborar uma crítica sistemática ao modo ideológico de produção das ciências humanas que se afirma e se reproduz na escola. Os umutinas se inseriram no projeto como professores formadores e coordenação, no sentido de promover o debate sobre o tema desde a perspectiva indígena entre as escolas do polo do Cefapro, tendo em vista principalmente já terem inserido essa discussão no seu projeto formativo e na discussão do currículo escolar e projeto político-pedagógico da Escola Jula Paré.

E, por último, os projetos relacionados à promoção do acesso dos profissionais da educação das escolas indígenas, do campo e quilombo. No contexto da Escola Jula Paré, as ações formativas relacionadas ao acesso aos programas de pós-graduação stricto sensu desenvolveram-se a partir de 2010 e, inicialmente, tinham um caráter bastante informal. No entanto, desde as primeiras ações, o objetivo foi bastante claro: apoiar a formação continuada de professores com vistas ao ingresso nos programas de pós-graduação stricto sensu como uma estratégia fundante da política de formação continuada do estado de Mato, com força para combater os efeitos de séculos de políticas educacionais que alijaram dos espaços autorizados da pesquisa acadêmica os povos indígenas. 
Entre os umutinas, as ações mais significativas se deram no contexto do Projeto Equidade na Pós-Graduação, em 2012. O projeto aconteceu a partir de uma parceria do Cefapro com o Núcleo de Estudos de Educação e Diversidade(NEED), coordenado pelo Núcleo de Estudos de Gênero e Alteridade(NEGRA), da UNEMAT, e financiado pela Fundação Ford(FF). No polo de Tangará da Serra, foram selecionados 50 inscritos, dos quais, 12 eram oriundos da Aldeia Umutina. A proposta de apoio a projetos seguiu no polo em 2013 e 2014, no contexto das ações do Terra como Princípio Educativo preparatório para mestrado e doutorado.

Para os professores indígenas e no contexto da formação continuada, essa orientação da política de formação se firma pela potencialidade que apresenta tanto de promover o acesso aos programas stricto sensu de populações historicamente excluídas do acesso ao Ensino Superior quanto de, ao ter como objetivo promover o debate sobre a escola indígena desde a perspectiva dos próprios povos indígenas, poder contribuir com a atual discussão sobre os modos como se constituíram os saberes no ocidente capitaneado pela colonização ibérica e pelo atual modelo de globalização da economia.

Os resultados das demandas pelo acesso aos níveis mais altos da educação dos umutinas são únicos entre as escolas do polo do Cefapro: em 1994, não havia professores umutinas que houvessem concluído o Ensino Médio; já em 2009, no sistema estadual de ensino, trabalharam nove professores, e todos haviam concluído o curso de graduação entre os anos 2000 e 2010. Em 2015, todos os professores umutinas na rede estadual já tinham completado um curso de graduação e/ou pós-graduação na sua área de atuação, e já havia, entre eles, dois trabalhos de mestrado concluídos e outros dois projetos de mestrado e doutorado em andamento.

É importante também registrar que é possível afirmar que a formação docente teve impacto nos números de acesso dos estudantes umutinas aos cursos de graduação. Entre 2009 e 2013, dos 53 estudantes umutinas que concluíram o Ensino Médio, 16 foram aprovados em vestibulares de universidades públicas, e, nesse grupo de estudantes oriundos do Ensino Médio na aldeia, já há registro de aprovados para os programas de mestrado oferecidos pela Universidade Federal de São Carlos (UFSCar), Universidade Estadual de Campinas(Unicamp) e Universidade Federal de Mato Grosso(UFMT).

Tais números se tornam ainda mais significativos quando considerados os dados já informados sobre o violento processo de contato e extermínio que ainda se abatia sobre nós na primeira metade do século XX. Os que sobrevi- 
veram foram submetidos a um projeto de educação escolar que se estabeleceu entre eles a partir de uma perspectiva integracionista e violenta desde 1943.

Entre os umutinas, como no restante do Brasil, a discussão sobre a formação docente toma formas e modalidades em um contexto altamente complexo, marcado por grandes desigualdades. Do nosso ponto de vista, foram as demandas e, principalmente, as especificidades da demanda do projeto formativo da Escola Estadual Indígena Jula Paré que ajudaram a construir uma noção de formação docente em serviço com desdobramentos que se verificaram nos processos de ensino e aprendizagem que se desenvolveram na escola, nos documentos e nas proposições políticas da escola e da comunidade, na ampliação do acesso dos estudantes concluintes do Ensino Médio ao Ensino Superior e na busca qualificada e sistemática dos trabalhadores docentes e não docentes da escola pelos níveis mais altos de formação escolar no Brasil.

Finalmente, queremos que essas discussões ampliem, nos contextos formativos capitaneados pelo Estado, uma perspectiva de formação continuada capaz de contribuir para superar o paradigma hegemônico de produção e valoração dos saberes organizados desde a lógica da modernidade e com força para contribuir com a construção de um modelo de educação escolar mais adequado aos contextos multiculturais em que vivemos.

\section{Referências}

BANIWA, Gersen. "Os saberes indígenas e a escola: é possível uma Escola Indígena Intercultural?”. Educação Escolar Indigena: diversidade sócio-cultural indigena, ressignificando a escola. Cadernos SECAD 3. Brasília: SECAD/MEC, 2007.

ESCOLA eSTAdUAL INDÍGENA JULA PARÉ. Projeto Político Pedagógico. Aldeia Umutina, 2009. Atualização 2013.

. Projeto Sala de Educador INYÃNZÓ. Aldeia Umutina, 2013.

. Projeto Sala de Educador A-Menú (Caminhar). Aldeia Umutina, 2014.

MATO GROSSO. Politica de formação dos profissionais da educação básica. Cuiabá: Secretaria de Estado de Educação, 2010. 
. Decreto n.o 2007/1997/SEDUC/MT. Dispõe sobre a criação do CEFAPRO nos municípios de Rondonópolis, Diamantino e Cuiabá, 1997.

. Parecer Orientativo: projeto Sala de Educador. Cuiabá: SEDUC/ SUFP, 2013.

. Parecer Orientativo: projeto Sala de Educador. Cuiabá: SEDUC/ SUFP, 2014.

PORTO-GONÇALVES, Carlos W. "Da geografía às geo-grafias: um mundo em busca de novas territorialidades". In CECENAA, Ana Esther y SADER, Emir (coord.). La Guerra Infinita: hegemonia y terror mundial. Buenos Aires: CLACSO, 2002.

RIBEIRO, Darcy. Os indios e a civilização: a integração das populações indígenas no Brasil Moderno. São Paulo: Companhia das Letras, 1996.

SCHMIDT, Max. "Los Barbados os umutinas em Mato Grosso". Revista de la Sociedad Cientifica del Paraguay, n. 5, pp. 1-51, 1941.

SCHULTZ, Harold. Vinte e três indios resistem à civilização. São Paulo: Melhoramentos, 1953.

- "Informações etnográficas sobre os umutina". Revista do Museu Paulista, Nova Série, v. 13, pp. 75-313, 1961/62.

SOUZA, Hellen Cristina de Souza e MONZILAR, Eliane Boroponepá. A flecha do tempo não segue um plano pré-determinado (mimeo). 2014. 


\title{
Formação de professores de História no exercício da docência
}

0 caso do PROFHIST

\author{
José Iran Ribeiro \\ Leonice Alves Pereira Mourad
}

\begin{abstract}
A educação é permanente não porque certa linha ideológica ou certa posição política ou certo interesse econômico o exijam. A educação é permanente na razão, de um lado, da finitude do ser humano, de outro, da consciência que ele tem de finitude. Mas ainda, pelo falto de, ao longo da história, ter incorporado à sua natureza não apenas saber que vivia, mas saber que sabia e, assim, saber que podia saber mais. A educação e a formação permanente se fundam aí (Freire, 1997, p. 20).
\end{abstract}

\section{Introdução}

O presente artigo objetiva apresentar sumariamente a experiência de formação continuada de professores de História a partir da proposta do PROFHIST. Nesse contexto, destaca-se a importância da compreensão do papel desempenhado pelos mestrados profissionalizantes, no caso em tela, a partir da constituição de uma rede, bem como a necessária qualificação dos docentes de educação básica. Apresenta-se uma discussão introdutória sobre os mestrados profissionais para, na sequência, analisar a experiência que vem sendo implementada desde o ano de 2014, quando ocorreu o ingresso da primeira turma de pós-graduandos. Nesse sentido, utilizaremos dados disponibilizados pela Capes, PROFHIST, bem como do programa de pós-graduação do 
referido mestrado na Universidade Federal de Santa Maria. Cumpre esclarecer aos leitores que este texto resulta de uma pesquisa exploratória e descritiva acerca da experiência formativa do mestrado profissional em ensino de História na UFSM.

\section{Formação de professores}

A temática da formação de professores é matéria de suma importância, sendo objeto de inúmeras reflexões, bem como de políticas e programas do poder público em seus diferentes níveis e sistemas de ensino, em consonância com dispositivos internacionais similares, sendo que ações para formação continuada de docentes intensificaram-se a partir dos anos de 1980 (SEF, 1999).

Estudos de Tardif e Nóvoa apontam que, na década de 1990, o Estado passa a conceber a formação continuada como um mecanismo para a construção de um novo perfil identitário para os docentes, ainda que sejam muitas as tendências que disputam tal processo.

Durante muito tempo e de forma reducionista, concebia-se a formação docente como resultante majoritariamente, quiçá unicamente, da trajetória escolar, sobretudo no ensino superior, disponibilizada pelos cursos de formação de professores, na forma de licenciaturas.

Reduzidos ou quase invisibilizados eram as preocupações e os estudos sobre a formação continuada de professores, com especial destaque à formação em exercício profissional. Da mesma forma, elementos da prática docente no interior da escola não eram percebidos como relevantes na formação docente, sendo por vezes naturalizados.

A primeira assertiva antes exposta decorre de uma concepção de sociedade e de conhecimento marcada por uma ideia de permanências, no que tange a questões formativas decorrentes da trajetória universitária. Ademais, devemos destacar a existência de pós-graduações, lato e stricto sensu deveras preocupadas com uma noção de prática docente e de pesquisa que tinha como lócus privilegiado o ensino superior, não havendo uma preocupação substantiva com a formação de professores para atuarem na educação básica.

As vultosas e aceleradas transformações pelas quais passa a sociedade contemporânea, também identificada como "sociedade da informação", têm demandado a constituição de novos paradigmas para tratar da formação de 
professores, materializando-se a necessidade de espaços e experiências formativas em consonância com essas transformações, tendo como preocupação central a necessária compreensão e intervenção no espaço escolar, como uma forma de qualificar as relações de ensino-aprendizagem, em um esforço de distanciamento/reconfiguração de uma trajetória formativa de pós-graduação que prime exclusivamente pela discussão teórica, sem uma significativa preocupação com a uma dimensão mais operacional e prática.

Acerca da necessária articulação entre essas duas dimensões, destacamos as reflexões de Pimenta (2005, p. 14): “a atividade teórica por si só não leva a transformação da realidade, não se objetiva, e não se materializa não sendo, pois, práxis. Por outro lado, a prática também não fala por si mesma, ou seja, teoria e prática são indivisíveis como práxis".

Cumpre salientar ainda que durante muito tempo predominou uma perspectiva que compreendia a formação continuada de professores como tão somente processos de atualização e capacitação, não preocupados em disponibilizar aos docentes elementos de natureza técnica e científica que, de fato, permitissem a construção e ressignificação desses elementos no espaço escolar.

Sobre essa demanda, Imbernón (2001, pp. 48-9) afirma que:

A formação terá como base uma reflexão dos sujeitos sobre sua prática docente, de modo a permitir que examinem suas teorias implícitas, seus esquemas de funcionamento, suas atitudes etc., realizando um processo constante de auto-avaliação que oriente seu trabalho. A orientação para esse processo de reflexão exige uma proposta crítica da intervenção educativa, uma análise da pratica do ponto de vista dos pressupostos ideológicos e comportamentais subjacentes.

Na sequência, apresentaremos de forma sumária alguns autores cujos estudos se notabilizaram pela preocupação em compreender os processos de formação e profissionalização de docentes.

Paulo Freire, em diversas passagens de sua obra, chama a atenção para a formação docente, privilegiando, em consonância com a sua perspectiva de mundo e de educação, processos formativos e de profissionalização disponíveis e operantes fora do espaço institucional, resultantes de um conjunto de variáveis decorrentes de temáticas de ordem sócio-histórica e éticas a serem desveladas e ressignificadas em toda a trajetória dos educadores. A despeito de 
relevância atribuída ao autor a essa dimensão formativa, este valoriza sobremaneira a formação escolar e a formação acadêmica desses sujeitos na medida em que acredita em uma educação que viabilize a autonomia. Nesse sentido, a obra Pedagogia da autonomia notabiliza-se pelo conjunto de reflexões e apontamentos acerca da união de saberes necessários à pratica educativa, de tal sorte a privilegiar a curiosidade epistêmica do docente.

José Carlos Libâneo problematiza os processos de formação de professores e evidencia a relação entre teoria e prática, destacando a necessidade de investigações que potencializem a reflexão dos docentes sobre a sua própria prática com base no espaço escolar, primando por um docente que seja capaz de viabilizar que os discentes pensem sobre o mundo.

Antonio Nóvoa (1995), da Universidade de Lisboa, em Portugal, apresenta um conjunto importante de reflexões sobre a formação do professor, profissionalização docente, bem como sobre a importância da prática docente como lócus de formação privilegiado, salientando ainda a relevância da identidade profissional na medida em que sustenta que "o professor se forma na escola".

Já Gimeno Sacristán destaca-se por sua contribuição ao pensar o currículo, as condições de desenvolvimento e a realidade curricular compreendidos em conjunto, entendendo o currículo como elemento de significado educativo em constante construção e transformação, enfatizando seus desdobramentos na formação de professores.

Para Sacristán (1999, s.p.),

Entendemos por formación, el proceso permanente de adquisición, estructuración y reestructuración de conductas (conocimientos, habilidades, valores) para el desempeño de una determinada función: en este caso, la docente. Tradicionalmente, se otorgo el monopolio de la misma a la formación inicial. Pero la modelación de las practicas y del pensamiento, así como la instrumentación de estrategias de acción técnico-profesionales operan desde la trayectoria escolar del futuro docente, ya que a través del transito por diversos niveles educativos el sujeto interioriza modelos de aprendizaje y rutinas escolares que se actualizan cuando se enfrenta ante situaciones donde debe asumir el rol de profesor. Asimismo, es sabido que actúa eficientemente la socialización laboral, dado que los docentes principiantes o novatos adquieren en las instituciones educativas las herramientas necesarias para afrontar la compleji- 
dad de las practicas cotidianas. Esta afirmación se funda en dos razones: la primera,la formación inicial no prevé muchos de los problemas de la practica diaria; la segunda, los diversos influjos de los ámbitos laborales diluyen, en buena medida, el impacto de la formación inicial. En tal sentido, las instituciones educativas mismas donde el docente se inserta a trabajar se constituyen también en formadoras, modelando sus formas de pensar, percibir y actuar, garantizando la regularidad de las practicas y su continuidad a través del tiempo. Por ello, nos referimos también muy especialmente a la formación docente continua, la que se lleva a cabo en servicio, a lo largo de toda la carrera, de toda la practica docente, y debe tomar a esa misma practica como eje formativo estructurante.

Maurice Tardif apresenta um conjunto importante de apontamentos tendo como categoria de análise o trabalho docente, buscando a interação entre os campos do saber, destacando ainda a existência de saberes específicos que caracterizam a profissão docente, sendo estes elaborados pelos professores tanto no seu processo de formação para o trabalho quanto no próprio cotidiano de suas atividades como docentes, daí resultando a integração desses tipos de saberes decorrentes da socialização que pode ser anterior à docência ou decorrente desta.

O autor salienta a existência de um "saber plural, formado de diversos saberes provenientes das instituições de formação, da formação profissional, dos currículos e da prática cotidiana" (Tardif, 2002, p. 54).

Ao final dessa sessão, enfatizamos a importância da formação continuada de professores, processo este que pode ser concebido a partir de diferentes abordagens, mas que, para o caso em tela, melhor se orienta pelos apontamentos dos autores antes expostos.

\section{Mestrados profissionalizantes}

Os debates sobre mestrados profissionalizantes, ainda que constantemente referidos na Portaria da Capes n. ${ }^{\circ}$ 47, de 17 de outubro de 1995, tiveram sua primeira referência expressa no Parecer n. ${ }^{\circ}$ 977/65, de Newton Sucupira, ${ }^{1}$

\footnotetext{
1 Disponível em: http://www.capes.gov.br/images/stories/download/legislacao/Parecer_ CESU_977_1965.pdf.
} 
que balizou a regulamentação da pós-graduação no país. No referido documento, quando da justificativa e motivação para a criação da pós-graduação, encontramos expressamente no item três a passagem que segue:

\section{[...] motivos fundamentais que exigem, de imediato, a instauração de sis- tema de cursos pós-graduados: [...]; 3) assegurar o treinamento eficaz de técnicos e trabalhadores intelectuais do mais alto padrão para fazer face às necessidades do desenvolvimento nacional em todos os setores.}

Ainda nele, privilegiou-se, naquele contexto, a constituição da pós-graduação denominada de acadêmica, constante no item 1: "estimular o desenvolvimento da pesquisa científica por meio da preparação adequada de pesquisadores" (Parecer n. ${ }^{\circ}$ 977/65).

Nesse contexto, consolida-se, no país, a pós-graduação stricto sensu (mestrado e doutorado) com o propósito de formação dos professores para o ensino superior com acurada formação técnico-científica.

As discussões sobre a importância dos mestrados profissionais mobilizam importantes setores da sociedade brasileira; em 14 de outubro de 1995, a Capes disponibilizou, por meio de uma Portaria, o "Programa de Flexibilização do Modelo de Pós-graduação Senso Estrito em Nível de Mestrado”, que estabelece procedimentos para a recomendação, acompanhamento e avaliação de cursos de mestrado voltados à formação profissional estabelecendo níveis de qualidade.

No referido documento, encontramos referência às instituições proponentes; aos docentes e orientadores e suas respectivas titulações e produções, que devem ser pertinentes aos objetivos do curso; à necessária articulação entre as atividades de ensino com as aplicações de pesquisas, bem como uma estrutura curricular concebida em consonância com a especificidade do curso e ser compatível com um tempo de titulação mínimo de um ano. Há referência, ainda, ao trabalho final, que deverá demonstrar domínio do objeto de estudo, sendo que este poderá ter a forma de dissertação, projeto, análise de casos, performance, produção artística, desenvolvimento de instrumentos, equipamentos, protótipos etc.

A Portaria n. ${ }^{\circ} 80$, de 16 de dezembro de 1998, da Capes, apresenta um conjunto de argumentos que justificam o reconhecimento dessa modalidade, enfatizando principalmente a seguinte questão: 
a) a necessidade da formação de profissionais pós-graduados aptos a elaborar novas técnicas e processos, com desempenho diferenciado de egressos dos cursos de mestrado que visem preferencialmente um aprofundamento de conhecimentos ou técnicas de pesquisa científica, tecnológica ou artística;

b) a relevância do caráter de terminalidade, assumido pelo Mestrado que enfatize o aprofundamento da formação científica ou profissional conquistada na graduação, aludido no Parecer no 977, de 03/12/65, do Conselho Federal de Educação [...]

Nesse contexto, são mestrados profissionalizantes cursos que atendam aos seguintes critérios:

a) estrutura curricular clara e consistentemente vinculada a sua especificidade, articulando o ensino com a aplicação profissional, de forma diferenciada e flexível, em termos coerentes com seus objetivos e compatível com um tempo de titulação mínimo de um ano; b) quadro docente integrado predominantemente por doutores, com produção intelectual divulgada em veículos reconhecidos e de ampla circulação em sua área de conhecimento, podendo uma parcela desse quadro ser constituída de profissionais de qualificação e experiência inquestionáveis em campo pertinente ao da proposta do curso; c) condições de trabalho e carga horária docentes compatíveis com as necessidades do curso, admitido o regime de dedicação parcial; d) exigência de apresentação de trabalho final que demonstre domínio do objeto de estudo, (sob a forma de dissertação, projeto, análise de casos, performance, produção artística, desenvolvimento de instrumentos, equipamentos, protótipos, entre outras, de acordo com a natureza da área e os fins do curso) e capacidade de expressar-se lucidamente sobre ele (CAPES, 1998).

A ratio legis da referida portaria estava orientada para a efetiva distinção entre duas modalidades de mestrado, o acadêmico e o profissional, que antes eram oferecidas de maneira indistinta, salientando que os mestrados profissionalizantes são equiparáveis, para fins de titulação ou concurso aos mestrados acadêmicos.

Janine Ribeiro, acerca dessa questão, enfatiza que: 
Mas aqui o que nos importa é enfatizar que todos os mestrados avaliados pela Capes, sejam eles acadêmicos ou profissionais, compartilham duas características principais pelo menos: primeira, eles passam por um crivo de rigor que atesta sua qualidade; segunda (e de alguma forma ligada à primeira), eles promovem uma mudança no perfil do aluno, um salto qualitativo em sua formação. É este ponto que convém enfatizar, aqui (2005, p. 313).

É nesse contexto que temos uma oferta expressiva de mestrados profissionalizantes, inicialmente ofertados para as áreas tecnológicas, para, na sequência, consolidar-se na grande área de educação, a partir dos programas em ensino.

\section{Mestrado Profissional em Ensino de História em Rede Nacional (ProfHistória)}

A pós-graduação stricto sensu na área de História data de meados dos anos 1970, quando da promulgação das novas regras da pós-graduação brasileira, tendo como referência experiências episódicas anteriores em algumas grandes universidades. Nos anos de 1980/90, a oferta de bolsas potencializou a pós-graduação, de sorte a ocorrer a efetiva profissionalização da pesquisa histórica no país.

Dados disponibilizados pela Capes evidenciam que a área de História conta, no ano de 2017, com 71 programas de pós-graduação, nove dos quais são de mestrado profissional. Dos 62 programas acadêmicos, 39 contam com cursos de mestrado e de doutorado, e 23 oferecem apenas o curso de mestrado.

O ProfHistória (Mestrado Profissional em Ensino de História), programa em rede nacional que reúne 27 instituições associadas, foi constituído no ano de 2012 a partir de uma rede de 13 instituições de ensino superior (IES). No ano de 2017, ocorreu a terceira seleção nacional para o ingresso no Programa, e, em 2016, a primeira turma de alunos defendeu sua dissertação.

Quando da análise do documento de área de História, encontramos referência a várias possibilidades de investigação a serem levadas a termo no Mestrado Profissional em Ensino de História, com especial destaque a: patrimônio histórico; arquivística; serviços de pesquisa e documentação; museologia e museografia; artes; turismo; organização de informações históricas; 
consultorias e pareceres históricos; ensino e material didático. O documento evidencia que a área "possui vínculos fortes e responsabilidades coma educação básica, inclusive tendo em vista que todos os seus docentes atuam nos cursos de graduação, os quais formam, majoritariamente, professores que trabalharão nessa esfera de atuação" (site ProfHistória).

Quando da criação da rede, estabeleceu-se como objetivo:

O Mestrado Profissional em Ensino de História em Rede Nacional (ProfHistória) tem como objetivo proporcionar formação continuada que contribua para a melhoria da qualidade do exercício da docência em História na Educação Básica, visando a dar ao egresso qualificação certificada para o exercício da profissão de professor de História (Art. 1 - Regimento ProfHistória).

O curso funciona na modalidade presencial, com seleção e oferta nacional concomitante, disponibilizando o título de mestre em Ensino de História. A coordenação da rede é responsabilidade da Universidade Federal do Rio de Janeiro (UFRJ) e integrada por comissões acadêmicas locais.

Administrativamente, devemos enfatizar que a coordenação das atividades do ProfHistória é formada por um comitê gestor, pela comissão acadêmica nacional e pelas comissões acadêmicas locais, responsáveis pelo gerenciamento do curso em três níveis.

O ingresso dos mestrandos no ProfHistória, assim como a distribuição de bolsas de estudos, ocorre por meio de um Exame Nacional de Acesso, ${ }^{2}$ versando sobre um programa de conteúdo previamente definido e divulgado por um edital.

Podem matricular-se no ProfHistória diplomados em cursos de licenciatura reconhecidos pelo Ministério da Educação, com atuação na disciplina

\footnotetext{
${ }^{2}$ O Exame Nacional de Acesso consiste num único exame, realizado pelo menos uma vez por ano, ao mesmo tempo, nas instituições associadas, pelas comissões acadêmicas locais; $\$ 2^{\circ}$ - As normas de realização do Exame Nacional de Acesso, incluindo os requisitos para inscrição, os horários e locais de aplicação do exame, o número de vagas em cada instituição associada, e os critérios de correção são definidos por Edital elaborado pela comissão nacional acadêmica; $\$ 3^{\circ}$ - A seleção dos discentes aprovados e a distribuição de bolsas de estudos em consonância com os requisitos determinados pelas agências de fomento se dão pela classificação dos candidatos no Exame Nacional de Acesso, consideradas separadamente as ofertas de vagas disponíveis pelas comissões acadêmicas locais.
} 
escolar História na educação básica, que atendam às exigências do edital de Exame Nacional de Acesso ao ProfHistória.

A matrícula dos discentes é efetivada nas instituições associadas, responsáveis por emitir o diploma de mestre em Ensino de História, desde que atendidos todos os requisitos para conclusão desse curso.

A organização curricular deve observar rigorosamente o projeto acadêmico-pedagógico do ProfHistória, estruturado nas seguintes linhas de pesquisa: $1^{\text {a) }}$ Saberes históricos no espaço escolar; $2^{\mathrm{a}}$ ) Linguagens e narrativas históricas: produção e difusão; $3^{\mathrm{a}}$ ) Saberes históricos em diferentes espaços de memória.

No que diz respeito ao trabalho de final de curso, o artigo 15 , do regimento interno, estabelece que:

A dissertação do ProfHistória tem por objetivo traduzir o aprendizado ao longo do percurso de formação bem como gerar conhecimento que possa ser disseminado, analisado e utilizado por outros profissionais dessa área nos diferentes contextos onde são mobilizadas diferentes formas de representação do passado. $\$ 1^{\circ}$ - A natureza da dissertação, a despeito do formato que possa vir a assumir, deve traduzir obrigatoriamente as três dimensões trabalhadas ao longo do curso: (i) a apropriação dos estudos e debates recentes sobre as temáticas trabalhadas; (ii) a criticidade em termos do conhecimento e práticas acumuladas na área e (iii) as possibilidades de produção e atuação na área do Ensino de História que contribuam para o avanço dos debates e a melhoria das práticas do profissional de História dentro e/ou fora da sala de aula. Para tal, ele constará de duas partes: uma parte crítico-analítica (dimensões i e ii) e uma parte propositiva (dimensão iii).

O produto final pode ser texto dissertativo, documentário, exposição, material didático, projeto de intervenção em escola, museu ou espaço similar, em consonância com alguma das linhas, sendo a defesa precedida de exame de qualificação, ambas feitas em arguição pública.

$\mathrm{Na}$ Universidade Federal de Santa Maria, o curso está lotado no Centro de Educação, congregando professores dos Departamentos de História, Metodologia do Ensino, Fundamentos da Educação e Administração Escolar, sendo oferecidas 13 vagas a cada oferta. 
Na primeira turma que ingressou em 2014-2, todos os discentes concluíram o curso, havendo uma turma com 12 alunos que já concluíram os créditos e estão elaborando seus trabalhos finais, havendo a previsão de início de uma terceira turma em 2018-1. Os discentes do ProfHistória-Santa Maria são oriundos do próprio município, bem como de municípios em um raio de até $200 \mathrm{~km}$, com algumas exceções de alunos que vêm da região metropolitana de Porto Alegre e da Serra Gaúcha, sendo as aulas ministradas nas sextas- feiras à tarde e à noite e aos sábados pela manhã e tarde.

Os trabalhos de final de curso apresentados até o momento versam sobre temáticas gerais de ensino de História e educação, predominantemente propondo e implementando intervenções no cotidiano escolar e com raras exceções trabalhos na forma de dissertações.

Como característica importante desse programa, destacaríamos a articulação com outras IES no Rio Grande do Sul que oferecem o mesmo programa, com especial destaque à Universidade Federal do Rio Grande do Sul, Universidade de Caxias do Sul e Universidade Federal do Rio Grande.

\section{Considerações finais}

A título de considerações finais, destacamos a importância das propostas de formação continuada de docentes de História por meio do ProfHistória, cuja proposta consiste em auxiliar no processo de qualificação rigorosa de docentes, comprometidos em compreender e construir estratégias, recursos e reflexões acerca do ensino de História.

Propostas dessa natureza estão em consonância com os documentos de área da História, bem como com as políticas nacionais e internacionais de formação de professores, de tal sorte a desmistificar a pesquisa, na medida em que o professor pesquisador se coloca como um sujeito privilegiado no que diz respeito a buscar uma efetiva aproximação entre produção acadêmica com o conhecimento escolar, Isso para produzir um conhecimento que, de fato, tenha sentido para todos os sujeitos envolvidos no processo de ensino e aprendizagem, o que já vem ocorrendo entre os egressos do ProfHistória da UFSM. 


\section{Referências}

BRASIL. Ministério da Educação e Cultura. Parecer CFE n. 977/65, aprovado em 3 dez. 1965. Revista Brasileira de Educação. [online]. n. 30, pp. 162-73, 2005. Disponível em: http://dx.doi.org/10.1590/S141324782005000300014 .

CAPES. Portaria n. ${ }^{\circ} 080$, de 16 de dezembro de 1998. Dispõe sobre o reconhecimento dos mestrados profissionais e dá outras providências. Diário Oficial da República Federativa do Brasil, Brasília, 11 jan. 1999. Seção 1, p. 14. Disponível em: http://www.capes.gov.br/ export/sites/capes/ download/legislacao/Portaria_CAPES_080_1998.doc.

FREIRE, P. Política e educação. São Paulo: Cortez, 1997.

. Pedagogia da autonomia: saberes necessários à prática educativa. São Paulo: Paz e Terra, 2001.

GIROUX, Henry A. Os professores como intelectuais: rumo a uma pedagogia critica da aprendizagem. Porto Alegre: Artes Médicas, 1997.

IMBERNÓN, F. Formação docente e profissional: formar-se para a mudança e a incerteza. São Paulo: Cortez, 2001.

JANINE RIBEIRO, Renato. "O mestrado profissional na politica atual da Capes”. Revista Brasileira de Pós-Graduação, v. 2, n. 4, pp. 8-15, Brasília, jul. 2005. Seção Debates. Disponível em: http://www.capes.gov.br/rbpg/ portal/conteudo/Debates_Artigol_n4.pdf.

NÓVOA, A. Formação contínua de professores: realidades eperspectivas. Aveiro: Universidade de Aveiro, 1991.

(Coord.). Os professores e a sua formação. 2 ed. Lisboa: Dom Quixote, 1995.

PIMENTA, Selma Garrido (org.). Saberes pedagógicos e atividade docente. 4. ed. São Paulo: Cortez, 2005.

. e GHEDIN, E (orgs.). Professor reflexivo no Brasil: gênese e critica de um conceito. São Paulo: Cortez, 2002.

PORTO, Y. da S. Formação continuada: a prática pedagógica recorrente. Campinas: Papirus, 2000. 
REGIMENTO GERAL DO PROFHISTÓRIA. Disponível em: http:// profhistoria.ufsm.br/.

SACRISTÁN, J.G. Poderes instáveis em educação. Porto Alegre: Artmed, 1999.

TARDIF, Maurice. Saberes docentes e formação profissional. 4 ed. Rio de Janeiro: Vozes, 2002.

e LESSARD, Claude. O trabalho docente: elementos para uma teoria da docência como profissão de interações humanas. 6 ed. Rio de Janeiro: Vozes, 2011.

VEIGA, I. P. Caminhos da profissionalização do magistério. Campinas: Papelivros, 1998. 


\section{Formação colaborativa na universidade}

\section{Possibilidades formativas para mudanças pedagógicas}

Mariane D. Martins

\section{Considerações iniciais}

O cenário mundial dos últimos tempos coloca a sociedade diante de muitos desafios. No Brasil, as crises da jovem democracia, da ética e da política nos desafiam a conversar mais sobre nossa história, nossas relações sociais e nossa política. No mundo globalizado, a sociedade da informação, com as tecnologias, reorganiza nossos entendimentos de tempo e lugar e nossas estruturas, exigindo que reflitamos sobre nossa realidade. Junto disso, as intolerâncias e incertezas nos colocam a refletir: qual sociedade estamos construindo? Nesse cenário desafiador e incerto, busco afirmar que a Educação continua sendo a melhor saída para a construção de processos sociais alternativos e justos, mas e se a Educação está em crise?

A sociedade contemporânea cada vez mais em rede, com noções de espaço e tempo ressignificados, necessita de outros tipos de processos de aprendizagem, logo de outros princípios de ensino. A compreensão de aprendizagem que esta sociedade exige não é mais aquela do início do século XX, e este é o maior desafio aos professores dessa época. A partir de tais mudanças que vêm ocorrendo, Nóvoa (2009, p. 27) afirma que

A educação vive um tempo de grandes incertezas e de muitas perplexidades. Sentimos a necessidade da mudança, mas nem sempre conseguimos definir-lhe o rumo. Há um excesso de discursos, redundantes e repetitivos, 
que se traduz numa pobreza de práticas. Há momentos em que parece que todos dizemos o mesmo, como se as palavras ganhassem vida própria e se desligassem da realidade das coisas.

Essas incertezas e perplexidade, que são parte da crise da Educação, refletem um momento muito difícil e particular, que é percebido em todas as instituições, e está em toda a sociedade. Trata-se, segundo Nóvoa (2009, p. 49), de um momento de transição.

As minhas palavras têm como pano de fundo a convicção de que estamos a viver uma fase de transição, na qual se assiste ao fechar de um ciclo histórico, durante o qual se consolidou uma determinada concepção do sistema de ensino, dos modos de organização das escolas e das estruturas curriculares, do estatuto dos professores e das maneiras de pensar a pedagogia e a educação.

A partir desse contexto de crise e transitório na educação, torna-se necessária uma reflexão profunda que resulte em mudanças objetivas no trabalho dos sujeitos envolvidos nos processos educativos. É possível que a própria falta de certezas e a desestruturação de nossas bases imaginativas e conceituais, daquilo que entendíamos como Educação, causem esse mal-estar e esses discursos desprovidos de prática. Ou mesmo, é essa desestruturação que reflete em nossa ineficiência diante desse momento de incerteza. Diante disso, Peters (2004, p. 49) é categórico na afirmação sobre as mudanças necessárias:

Não é suficiente nos adaptarmos às novas circunstâncias. Temos que repensar a educação, planejar novamente o ensino e a aprendizagem e implantar tudo de novas maneiras sob novas circunstâncias. É necessária uma reorganização estrutural ampla do ensino e da aprendizagem.

A partir disso, muitos são os desafios colocados no contexto educacional. A reestruturação colocada por Peters (2004) diante da transição (Nóvoa, 2009) exige reflexão que resulte em mudanças. No entanto, há questões primordiais a serem tratadas: a falta de investimento público, a baixa remuneração dos professores, as diferenças geracionais, as tecnologias na Educação, e um tema que é muito recorrente e fundamental - a formação de professores. 
Como esses sujeitos podem/devem atuar em cenário tão complexo? Foram formados para tal?

Além da formação inicial, a formação continuada de professores é pauta crucial na educação e segue sendo reiteradamente discutida, o que reflete sua relevância. Ao pesquisar apenas na base de dados da Capes as palavras "formação continuada, professores", imediatamente aparecem 4.074 trabalhos, afirmando sobre sua necessidade, seus desafios e suas mais diferentes facetas. A grande maioria das discussões versa sobre a formação continuada de professores das escolas. No entanto, já há muitas discussões em torno da formação continuada de professores universitários. Esse tema é importante, porque apenas um olhar rápido sobre esses sujeitos evidencia que a grande maioria é bacharel, o que reflete em lacunas na sua formação pedagógica e na atuação docente, gerando dificuldades na adoção e utilização de novas metodologias, estratégias e materiais de apoio (Rivas et al., 2007).

Tal profissional, ao entrar na universidade, deixa de ser apenas um bacharel de sua área para tornar-se um professor. É a partir da sua experiência em sala de aula que deverão ser constituídas as múltiplas identidades que existem na profissão e seu perfil profissional docente, sempre como processos em desenvolvimento (Nóvoa, 2017). E, talvez, ao se formar profissional na (ou apenas pela) experiência, nem sempre esse perfil será pedagógica e didaticamente mais adequado. Assim, a formação continuada na universidade deveria dar conta das questões pedagógicas desse profissional.

A partir do que vim descrevendo, em função das mudanças no cenário educacional, das lacunas formativas dos professores e novas necessidades dessa sociedade, os professores estão enfrentando dificuldades, e muitos deles não conseguem responder a esses desafios. Conforme afirma Nóvoa, "a crítica principal que hoje se dirige à escola diz respeito à sua incapacidade para promover as aprendizagens, respondendo assim aos desafios da sociedade do conhecimento" (2009, p. 77). Apesar de Nóvoa (2009) estar tratando da discussão dos professores de escola, ela se estende à universidade, pois as dificuldades de ensino são proporcionalmente iguais.

Assim, este artigo tem como objetivo refletir sobre a formação continuada de professores na universidade e indicar as potencialidades de uma "formação colaborativa”. O trabalho aqui apresentado se caracteriza por uma revisão bibliográfica explicativa, que versa sobre a formação continuada de professores universitários, embasada em uma dissertação, bem como em livros e artigos 
relacionados ao tema em questão. Gil (1991) aponta que a revisão bibliográfica é elaborada a partir de materiais bibliográficos, artigos e periódicos.

Este artigo alude a uma experiência de "formação colaborativa" feita a partir de uma pesquisa-ação. ${ }^{1}$ Esta aconteceu em 11 encontros com a participação de quatro professores universitários (Sargas, Izar, Girtab e Chertan) ${ }^{2}$ e a pesquisadora. Nesses encontros, a partir da leitura do texto de Juan Ignácio Pozo (2002), Aprendizes e mestres: a nova cultura de aprendizagem, e de algumas referências a conceitos de Vygotsky $(2007,2008)$, aconteceram debates e reflexões.

Os professores participantes foram desafiados a pensar a partir de uma disciplina que ministravam, sobre suas práticas na modalidade EaD. Depois de uma apresentação de como organizavam essa disciplina, nos primeiros encontros, com o posterior estudo dos autores citados e reflexóes, propus que refizessem suas propostas de aula na modalidade, que foram apresentadas nos últimos encontros. Dois deles buscaram reformular suas propostas de aula, apresentadas nas primeiras reuniões, e dois as mantiveram. Aqui, apresentarei um de cada grupo, por serem mais representativos em relação à reflexão a partir da "formação colaborativa".

\section{A universidade e o desafio da formação continuada de seus professores}

Ao partir de um campo de análise tão amplo, como a sociedade em transição e as crises brasileiras, para chegar à formação continuada de professores universitários, quero ressaltar a importância dessa instituição nesse contexto desafiador. A universidade, como o próprio nome diz, açambarca o universo das ciências da vida e precisa buscar refletir sobre as questóes que surgem nesses contextos de crise, a partir dos diferentes olhares que também a fazem "diversidade".

Assim, os desafios da sociedade são os desafios da universidade - se ela produz conhecimento, precisa buscar reflexões às questões colocadas pela sociedade. No dia a dia dessa instituição, as questões da Educação se colocam

\footnotetext{
${ }^{1}$ Este artigo foi feito a partir da dissertação de mestrado intitulada Processos de ensino e aprendizagem na modalidade de EaD: uma discussão a partir da compreensão de professores, apresentada no programa de Pós-Graduação em Educação nas Ciências da UNIJUÍ.

${ }^{2}$ Nome fictício usado para os professores.
} 
não só como tema de reflexão, mas também como realidade vivida. Por exemplo, ao mesmo tempo em que as TICs (Tecnologias de Informação e Comunicação) são parte das aulas, causando, muitas vezes, desconforto aos professores, estes deveriam estar refletindo sobre o impacto dessas ferramentas no seu trabalho e construindo conhecimento sobre elas. Nesse sentido, Barqueiro (2007, p. 12) afirma: "a Instituição educacional deve repensar o seu papel e função, pois não mais cabe perceber o espaço educacional como lugar à parte da sociedade e o conhecimento como algo estanque e descontextualizado".

Ao estabelecer essa relação direta da universidade com os desafios atuais da sociedade, a formação de professores universitários se complexifica. É necessária, assim, uma reflexão epistemológica sobre o trabalho docente. Este deve dar conta de propostas pedagógicas que abordem essa nova realidade, "conectada" e globalizada, na qual os conteúdos estão a um clique, disponibilizados de forma mais dinâmica e atraente que um PowerPoint ou aulas expositivas. A complexificação dessa atividade é explicitada:

A atividade docente no cotidiano exige decisóes imediatas, que passa pela relação professor-aluno, relação com o saber, por aspectos comunicacionais e afetivos de grupo, além dos racionais, em um processo de formação de pessoas. Se antes a profissão de professor calcava-se no conhecimento objetivo, no conhecimento das disciplinas, em muito semelhantes às outras profissões, hoje, apenas dominar esse saber é insuficiente, uma vez que o contexto das aprendizagens não é mais o mesmo. [...] O trabalho docente, que se constitui e transforma-se no cotidiano da vida social, implica o professor possuir um controle e uma autonomia, mesmo que relativos, sobre o seu processo de trabalho, uma vez que organiza e dirige o espaço para o ensino. $\mathrm{O}$ trabalho do professor possui uma totalidade, pois é um trabalho inteiro ainda que possa ser decomposto metodologicamente (Rivas et al., 2007, p. 5).

No entanto, à contramão da realidade complexificante, parece que a universidade está cada vez mais se individualizando. O professor atua em torno de um eixo individual, com sua turma, suas pesquisas, buscando sua formação pessoal (Rivas et al., 2007). A formação na universidade acaba, em geral, acontecendo por palestras, onde há pouco espaço para o sujeito falar de suas dificuldades ou refletir sobre seu trabalho. Nesse sentido, um dos professores participantes da formação continuada colaborativa afirmou: 
Isso que nós estamos fazendo aqui, a gente reclama de toda sexta ter o compromisso [se referindo aos encontros da pesquisa], mas ao mesmo tempo é o tempo em que nós estamos refletindo, porque é o momento que nós estamos nos dando para pensar, tempo que não temos normalmente (Sargas, 2016).

Nesse sentido, a formação continuada de professores deveria ter um papel importante como espaço de reflexão do professor sobre seu trabalho. Isso porque ela é entendida como "um processo que capacita professores no local de trabalho, oferecendo educação permanente, com apropriações de muitas competências, enriquecendo sua prática" (Teixeira, 2010, p. 2) e, aqui, poderia acrescentar, a partir de sua prática. No entanto, é comum a seguinte situação:

Muitos programas de formação contínua têm-se revelado inúteis, servindo apenas para complicar um quotidiano docente já de si fortemente exigente. É necessário recusar o consumismo de cursos, seminários e acções que caracteriza o actual 'mercado da formação' sempre alimentado por um sentimento de 'desactualização' dos professores. A única saída possível é o investimento na construção de redes de trabalho colectivo que sejam o suporte de práticas de formação baseadas na partilha e no diálogo profissional (Nóvoa, 2009, p. 23).

Ao concordar com esse entendimento de Nóvoa, a "formação colaborativa" coloca-se como uma possibilidade/alternativa à universidade. Neste trabalho, ela é referida a partir da experiência feita pela pesquisa-ação. Isso porque o processo desse tipo de formação deverá significar reflexão e aprendizados para os professores, e para isso acontecer é necessário que aconteça uma reflexão dos professores sobre o seu próprio fazer.

Trata-se, sim, de afirmar que as nossas propostas teóricas só fazem sentido se forem construídas dentro da profissão, se forem apropriadas a partir de uma reflexão dos professores sobre o seu próprio trabalho. Enquanto forem apenas injunções do exterior, serão bem pobres as mudanças que terão lugar no interior do campo profissional docente (Nóvoa, 2009, p. 19). 
Assim, a "formação colaborativa" é entendida como uma potência concreta nas universidades e que não necessita de maiores investimentos financeiros ou agentes externos. É vista como agente transformador, a partir do entendimento de Vygostky (2008), autor que coloca a colaboração do outro (seja professor, seja um interlocutor mais desenvolvido) como fundamental para alcançar ciclos de desenvolvimento e de aprendizagem. Aliado a esse entendimento, Meirinhos (2006, p. 61) afirma que a colaboração

visa à actuação conjunta e comprometida com determinados objectivos, o intercâmbio de informação e a partilha de ideias e de recursos. A colaboração está muito dependente de uma interacção e relacionamento positivos e de valores como a confiança, responsabilidade e respeito mútuo. Ou seja, a actividade colaborativa pressupõe a construção de uma realidade partilhada, vinculada a uma dinâmica relacional, onde são fundamentais os processos reflexivos, de resolução de problemas e de controlo da aprendizagem. A actividadecolectiva também não se pode separar da aprendizagem individual, na medida em que a auto-aprendizagem é o suporte da aprendizagem colaborativa.

O autor ainda segue afirmando que "A efectiva implementação da actividade colaborativa, entre professores, pode ser vista como uma forma de facilitar, ao mesmo tempo, o desenvolvimento profissional e o desenvolvimento institucional" (p. 61). Dessa maneira, além das compreensões prévias, o andamento da discussão nos 11 encontros reafirmou, como veremos, essa possibilidade colaborativa de formação e reforçou um conceito teórico, a partir da ação, com processos reflexivos baseados em um comprometimento do grupo com o objetivo de melhorar uma prática.

\section{A experiência da formação colaborativa na universidade}

A experiência de "formação colaborativa", que aconteceu com quatro professores e a pesquisadora, em 11 encontros, buscou comparar as falas e as propostas de aulas dos primeiros encontros com as dos últimos, buscando ver se havia mudanças/aprendizado a partir da reflexão feita no grupo. Essa 
análise foi feita a partir da construção de categorias analíticas sob a análise de conteúdo. ${ }^{3}$.

Nesses encontros, todos os professores participaram ativamente das discussões. Os dois professores que fizeram as alterações nas suas disciplinas foram Sargas e Girtab. As mudanças de ambos dizem diretamente em relação ao tipo de atividades propostas, discutido nos encontros por intermédio de Pozo. Segundo este autor, o tipo de atividade proposta pelo professor definirá o tipo de aprendizado; se repetitivo, trará um aprendizado associativo; se reflexivo, um aprendizado mais construtivo (Pozo, 2004). A seguir, tratei um quadro em relação à pesquisa com os quatro professores, pois ilustra de forma resumida as possibilidades de mudanças, em apenas 11 encontros de reflexão. No entanto, não me deterei na discussão deste, e sim em como ocorreram algumas reflexões importantes de dois sujeitos participantes.

Quadro 1: Comportamento das subcategorias e unidades de contexto

\begin{tabular}{|c|c|c|c|}
\hline Tema/categoria & Subcategoria & Unidade de contexto & Comportamento \\
\hline \multirow{2}{*}{$\begin{array}{l}\text { Aprendizagem na } \\
\text { modalidade } \mathrm{EaD}\end{array}$} & Repetitiva & $\begin{array}{c}\text { Tipo de atividade } \\
\text { repetitiva }\end{array}$ & \multirow{4}{*}{$\begin{array}{c}\text { Pode mudar no decorrer } \\
\text { dos encontros. }\end{array}$} \\
\hline & Construtiva & $\begin{array}{l}\text { Tipo de atividade } \\
\text { reflexiva }\end{array}$ & \\
\hline \multirow[b]{2}{*}{$\begin{array}{l}\text { Dificuldade dos } \\
\text { professores }\end{array}$} & $\begin{array}{l}\text { Processo } \\
\text { avaliativo }\end{array}$ & $\begin{array}{c}\text { A forma como fazem } \\
\text { a avaliaçáo }\end{array}$ & \\
\hline & $\begin{array}{l}\text { Atuação na } \\
\text { modalidade }\end{array}$ & $\begin{array}{l}\text { Dificuldade de de- } \\
\text { senvolver propostas } \\
\text { didáticas na modali- } \\
\text { dade EaD }\end{array}$ & \\
\hline \multirow[t]{2}{*}{$\begin{array}{l}\text { Visão sobre os } \\
\text { alunos }\end{array}$} & Desinteresse & $\begin{array}{c}\text { Não querem parti- } \\
\text { cipar/não acompa- } \\
\text { nham/leem }\end{array}$ & \multirow{2}{*}{$\begin{array}{l}\text { Não muda, mas apare- } \\
\text { cem contradiçóes nas } \\
\text { falas sobre os alunos. }\end{array}$} \\
\hline & Interesse & Boa participação & \\
\hline
\end{tabular}

Fonte: a autora (2016).

\footnotetext{
3 "Não se trata de um instrumento, mas de um leque de apetrechos; ou, com maior rigor, será um único instrumento, mas marcado com uma grande disparidade de formas e adaptável a um campo de aplicações muito vasto: as comunicações” (Bardin, 1997, p. 31).
} 
Ao construir o quadro que expressa uma parte da análise, percebi que o processo reflexivo proporcionou indicativos de mudanças em algumas categorias. Podemos ver que, na categoria aprendizagem na modalidade EaD e nas suas respectivas subcategorias - repetitiva ou reflexiva -, bem como na categoria dificuldade dos professores, na subcategoria processo avaliativo, houve alterações no final do processo de formação colaborativa. No entanto, a partir da análise individual dos professores, a "movimentação" das concepções iniciais não foi comum a todos. Essa contingência nas subcategorias me fez expressar no quadro acima, em relação ao comportamento, uma possibilidade ("pode mudar").

\section{0 processo reflexivo a partir da formação colaborativa}

A partir dessa rápida apresentação geral, passo a apresentar os caminhos reflexivos de dois professores. Um deles fez alterações em seu planejamento de aula, e o outro não fez. A escolha desses dois para este trabalho se deu por representarem melhor a relação que busco estabelecer entre a "formação colaborativa" e as possibilidades de reflexão e aprendizado dos professores, logo a potência deste tipo de formação dentro da universidade.

\section{Sargas}

O principal movimento reflexivo de Sargas iniciou com uma análise crítica do seu trabalho, no quinto encontro. Isso aconteceu a partir de exposição em PowerPoint, por meio da qual apresentei o conceito de Zona de Desenvolvimento Proximal. Nesse momento, falei da importância para Vygotsky do trabalho em grupo e de que para o autor, num primeiro momento, a imitação seria importante para a aprendizagem. Sargas (01/04/2016) interrompe:

Mas espera aí!! Não é aí que estamos travando na minha disciplina, o repetir? Eu trabalho em um modelo de orçamento, eles repetem, e daí na Atividade de ontem eles fazem o exercício e acaba sendo uma repetição. Onde eles abstraem? Até precisaria de mais tempo para eles fazerem as atividades. Eu saí pensando sobre isso, na minha próxima aula darei con- 
teúdo novo, eu pensei, uma aluna me disse: 'professor eu gostei muito, mas eu não consegui absorver, eu preciso de mais tempo para isso, para poder entender o que a gente está fazendo'. Ela trabalha no Bradesco e ela é bem interessada.

Com a fala da aluna, associada à discussão de Vygotsky, parece que Sargas percebe que os alunos têm pouca possibilidade de avançar nas reflexões nas suas aulas. Ele percebe que os alunos não conseguem "abstrair", ou sair da repetição, dos cálculos.

Mais adiante, Sargas (01/04/2016) fala de uma ideia que teve para as aulas do presencial e, na sequência, segue:

E aí eu estava pensando no que o prof. Girtab falou, 'Como fazer isso no EAD?'. Ele falou do Fórum de discussão. Não é frustrante perceber que o aluno não entendeu, não compreendeu? Eu não consigo ficar indiferente! Então isso que a Caroline me disse 'não tem tempo para pensar' [se referindo à fala da aluna relatada acima] vai sempre [desafiar].

Sargas parece estar incomodado com a sua forma de dar aula. Nessa intervenção, ele começa a manifestar algo como uma nova consciência sobre o seu trabalho de ensino e parece descrever sua dificuldade em fazer os alunos refletirem. Ele percebe que há uma consequência no aluno a partir do que propõe, ou não propõe, pelo que a aluna relata. Essa fala exemplifica também uma partilha ou um diálogo profissional, a saída apontada por Nóvoa (2009), para processos de formação assertivos. Os momentos dos encontros de "formação colaborativa”, que colocam a disciplina em discussão, parecem ter ajudado o professor a refletir com mais tempo sobre seu trabalho, e reflexo disso é que sua análise sobre a EaD é motivada a partir da fala de Girtab.

No sexto encontro, Sargas parece fazer uma análise bem crítica de sua disciplina, ao ler sobre o treinamento técnico:

[...] costuma ser iniciado com a apresentação de algumas instruções e/ou um modelo de ação. As instruções serviriam não só para fixar o objetivo da atividade (a meta para a qual se orienta o procedimento, segundo a definição), como principalmente para especificar em detalhe a sequência de passos e ações que devem se realizar (Pozo, 2007, p. 230). 
Após a leitura, quando é aberto para a discussão, Sargas comenta: "na verdade, olhando aqui e pensando, a gente está reproduzido um conhecimento técnico" (Sargas, 04/04/2016). Izar intervém: "Mas a gente tinha essa clareza!” (04/04/2016). E Sargas (04/04/2016) segue:

$\mathrm{Na}$ verdade, a gente está discutindo, explicitando e vendo que é possível, nas nossas disciplinas, avançar para mudar isso [referindo-se a sua recém análise em relação a reprodução do conhecimento técnico]. Além de eu ter um aprendiz novato, com domínio técnico, ele deve ter também o domínio estratégico. Ele deve saber chegar lá na empresa e implantar um orçamento. Deve ter um conhecimento técnico com as variáveis que eu ensinei em sala de aula, em $\mathrm{EaD}$, com atividades e exercícios, que permitam ele saber como implanta e trabalha, na empresa, como faz uma análise financeira.

Nessa fala, é possível perceber que o professor está pensando sobre seu trabalho ao ensinar seu conteúdo específico. Refletir e melhorar esse trabalho pode significar tanto o desenvolvimento profissional, quanto da instituição, conforme Meirinhos (2006).

No oitavo encontro, depois da leitura de Pozo (2002) sobre "estratégias de aprendizagem", que trata especialmente da diferença entre uma aprendizagem por associação, tida como "As estratégias mais simples, de repetição, se apoiaram numa aprendizagem associativa e serviram para reproduzir mais eficazmente um material, normalmente informação verbal ou técnica rotineiras" (p. 242) de uma aprendizagem por reestruturação:

A compreensão de um material de aprendizagem é facilitada quando o aprendiz utiliza procedimentos de compreensão e organização conceitual, tanto no discurso oral como escrito, voltados para o estabelecimento de relações conceituais entre os elementos do material e entre estes e os conhecimentos prévios do aprendiz (p. 243).

Os professores estavam fazendo uma discussão sobre o assunto, quando Girtab (04/04/2016) comenta: 
Ler o texto e interpretá-lo, eu acho que esse é o gargalo, porque o que acontece nas provas quando tem lá... Eles reclamam que o conteúdo é diferente do que eles estão discutindo em sala de aula, porque eles não leram o texto e transferiram para o cotidiano, então 'ah o índice que o professor deu é diferente então ela já fez diferente'. Eles não sabem a origem do índice.

Nesse instante, Sargas parece ter um insight e responde "Talvez porque a gente está trabalhando só no primeiro [se referindo a forma de aprendizado por associação], na questão simples só repetir, repetir, repetir. Será que não?” (Sargas, 04/04/2016).

Essa intervenção de Sargas parece muito significativa. Ela é resultado do conjunto de reflexões que o professor vinha fazendo desde a análise crítica sobre sua disciplina nos primeiros encontros em que começamos a discussão, até as possibilidades de mudança que poderia fazer. Ao compreender que não existe uma só forma de aprendizagem, ele, mais uma vez, faz a análise sobre a sua disciplina e parece chegar a um entendimento muito importante no oitavo encontro - isto é, depois de reflexões: o de que poderia produzir um diferencial na sua proposta de ensino. Essa fala também afirma uma apropriação a partir da reflexão do professor sobre seu próprio trabalho, apontando para possibilidades concretas de mudanças no campo profissional (Nóvoa, 2009).

Assim, pudemos perceber um desenvolvimento de Sargas, que partiu da análise criticando seu trabalho para a reflexão sobre as possibilidades que poderia desenvolver na disciplina. Ele construiu uma importante convicção: a escrita é uma "grande mudança". Pela análise de como trabalhava, com perguntas relacionadas ao resultado numérico, e a proposta atual, com perguntas de análise, evidencia-se uma mudança importante para a mobilização da reflexão do aluno. Junto com essa questão, a possibilidade de interação que ele visualiza a partir de turmas menores pode potencializar o aprendizado dos alunos.

Ainda em relação ao processo reflexivo de Sargas, poderia sugerir que, para além das teorias discutidas, é especialmente a interação que houve, entre o professor e os demais participantes, destacando os questionamentos colocados por Girtab, no processo de "formação colaborativa", que se coloca como fundamental para suas reflexões e a construção das mudanças na sua disciplina. A trajetória de Sargas afirma a importância da colaboração e reafirma a importância do diálogo entre os pares sobre seu trabalho na formação docente. 


\section{Izar}

Izar foi um professor que não apresentou mudanças ao final de sua disciplina, conforme já disse. No entanto, é interessante analisar seu processo reflexivo durante a experiência de "formação colaborativa". Isso porque foi um professor que esteve presente em todos os encontros e, de forma geral, centrou-se na discussão proposta, dialogando com os colegas. Seria possível compreender por que ele, que participou das discussões, não fez mudanças em sua disciplina? Ou ainda, não apresentar mudanças concretas na proposta de aula significa que não refletiu sobre seu trabalho? A partir do seu caminho reflexivo, buscarei encontrar essa resposta.

A primeira fala que trago de Izar é do quinto encontro. Girtab estava fazendo a discussão em relação à reflexão: "Quando não existe reflexão, não avança a questão da construção do conhecimento, esse é o papel da Universidade para mim" (01/04/2016). A partir dessa fala, Izar responde: "Mas eu acho que não é só o aluno, mas, às vezes, o docente também está limitado a esta condição, entende? E digamos assim, começa a se repetir as mesmices" (01/04/2016). Nessa fala, Izar faz uma análise dos professores em geral, afirmando que eles, tanto quanto os alunos, também têm dificuldade de construir processos reflexivos na universidade. Dessa maneira, mesmo que ainda não fale de si, ele demostra a preocupação com o papel da universidade em ser espaço de reflexão, apontando a dificuldade dos professores nisso.

No oitavo encontro, depois das combinações de agenda dos nossos encontros, fomos ler em Pozo (2002) as estratégias de aprendizagem por repetição ou elaboração e organização. Com o fim da leitura, Izar inicia a discussão:

A minha dúvida aqui é, qual é mais efetiva provavelmente por reestruturação, provavelmente né? E eu percebo assim, o nosso colega Girtab tem essa capacidade muito fácil de reestruturar a partir de algo, desculpa vou usar teu nome, não quero usar em vão também [ironiza, brincando]. Mas eu ainda preciso primeiro fazer a associação, repetição, sublinhando copiando, quando eu faço isso, depois eu consigo fazer algo por reestruturação. Eu tenho ainda, talvez seja uma questão, para desenvolver. Não sei se é uma habilidade que se consegue desenvolver, ou se é das 
características pessoais, no texto isso não trata exatamente isso. Qual é a mais? (Izar, 29/04/2016).

O professor Izar, nessa fala, além da dúvida apresentada em relação às teorias de aprendizagem, também faz uma análise sobre como ele constrói a sua aprendizagem. Um processo, pelo que diz, um pouco mais lento, inclusive se comparando a Girtab. Esse é um elemento importante em direção a uma análise pessoal sobre seu trabalho. Como vimos em Sargas, foi a partir de uma autocrítica que ele consegue repensar sua disciplina. Também exemplifica uma reflexão do professor sobre o seu próprio trabalho (Nóvoa, 2009).

Ainda nessa discussão, um pouco mais adiante, o professor Girtab fala de uma experiência em outra disciplina na modalidade EaD. Nesse caso, acredita que foi importante, no sentido de construir um processo de aprendizagem partindo daquilo que o aluno já sabia, para a elaboração e a aprendizagem significativa (Pozo, 2002). Na sequência, Izar comenta sobre seu trabalho, no diálogo que segue:

Izar: eu diria assim, na sala de aula, nas minhas disciplinas, eu não sei se a gente consegue passar da elaboração do simples, para complexas, olha!? Formar analogias ler textos é uma coisa bem...

Pesquisadora: e no EAD?

Izar: é no EaD, fora o livro texto é bem raro a gente conseguir convencer alguém a buscar novasinformações, ou fazer com que eles acessem esses novos parâmetros a partir do colocado (29/04/2016).

Nessa fala, destaco inicialmente a análise que Izar faz sobre seu trabalho e a dificuldade percebida em "passar da elaboração simples para complexas". Há, então, indícios de que ele admite a dificuldade em construir processos significativos de aprendizagem e a condição sua de construir processos "simples". A partir das discussões que vinham ocorrendo, poderia sugerir que as elaborações simples são os processos por repetição, apontado na teoria estudada.

Quando Sargas faz o questionamento sobre sua forma de trabalho, desconfiando de que ele propóe apenas a repetição, Izar responde conforme segue: 
Sargas: talvez porque a gente está trabalhando só no primeiro, na questão simples só repetir, repetir, repetir. Será que não?

Izar: é, foi o que eu disse, eu também não sei se eu consigo ultrapassar isso chegar até a... Aliás, a meta sempre é a restruturação, pensando inclusive que eles consigam formar uma ideia de conceitos de rede de conceitos, mas não sei se chega passar disso (29/04/2016).

Mais uma vez, parece que Izar expõe sua dificuldade em oportunizar processos mais reflexivos aos estudantes. Ele concebe como objetivo, mas não consegue afirmar a possibilidade de efetivar isso.

As falas de Izar nos apontam para questões que poderiam ser indícios analíticos de seu processo reflexivo. Parto da questão inicial, de que o professor não alterou sua proposta de trabalho. No entanto, podemos ver que no último encontro o professor fez análise a partir do seu trabalho no ensino EaD e sua dificuldade de produzir processos de aprendizagem mais construtivos.

Uma possibilidade de leitura dessa não alteração no seu plano de aula é partir da sua própria explicação, sobre seu processo de aprendizado mais demorado, por meio da qual ele precisa "sublinhar, repetir, fazer associação". Esse processo de tomar consciência de como aprende é fundamental, pois o professor parece construir um metaconhecimento. ${ }^{4}$ Isso explicita o que Meirinhos (2006) afirma sobre a colaboração, em que a atividade coletiva não pode separar da individual, pois a autoaprendizagem é suporte para o coletivo.

Ao identificar que suas análises críticas de seu trabalho aconteceram no último encontro, antes das apresentações finais das disciplinas, poderia apontar como um entendimento plausível de que talvez não teria dado tempo de o professor elaborar melhor suas reflexões. Talvez o professor Izar precisaria de mais tempo para refletir sobre seu trabalho e pensar nas mudanças necessárias em sua disciplina, além de precisar de um estudo mais apurado no material discutido nos encontros.

Outra análise possível é a de que o professor fez uma escolha consciente de não fazer nenhuma alteração na sua proposta de aula, já que ele identificou

\footnotetext{
${ }^{4}$ Um saber sobre o que sabemos, que pode nos ajudar a tomar consciência do nosso funcionamento cognitivo. "[...] essa reflexão consciente sobre os processos e produtos cognitivos deve, de algum modo, nos proporcionar melhores instrumentos cognitivos para intervir nesses processos e modificá-los" (Pozo, 2002, p. 158).
} 
que não consegue fazer um processo de aprendizado construtivo. Nesse ponto, não tenho elementos para supor os motivos de sua escolha. No entanto, independentemente do que for, fica evidente a reflexão a partir do diálogo com outros.

Esses dois exemplos de Sargas e Izar podem sugerir que os processos de formação de professores deveriam garantir espaços de diálogos e análise entre os pares sobre o próprio trabalho. Assim, considerando a trajetória dos professores nesses 11 encontros, poderíamos identificar alguns estágios em relação à "formação colaborativa" que reflita em mudanças. As etapas que exprimem o caminho reflexivo que o professor deveria fazer são: a) espaço de diálogos e/ou leituras, ou leituras com posterior diálogo, que permitam olhares críticos e questionadores sobre o objeto que se coloque para estudo; b) compreensão e autoconsciência dos questionamentos pelos sujeitos participantes; c) elaboração dos seus próprios questionamentos, a partir de uma análise crítica sobre seu trabalho; d) com base em um desafio, a construção de alternativas ao objeto, fundadas em um olhar crítico ao próprio trabalho. Nesse sentido, alvitro que uma proposta de construção de planejamento alternativo de disciplinas, para ser eficiente, deveria considerar esses estágios.

\section{Considerações finais}

Neste capítulo, buscamos refletir sobre a formação continuada de professores na universidade e indicar as potencialidades de uma "formação colaborativa”, mostrando parte de uma experiência de pesquisa-ação ocorrida com quatro professores universitários. Os apontamentos feitos neste trabalho nos permitem afirmar que a colaboração pode propiciar reflexões importantes a partir do tema discutido. No trabalho, trouxe a discussão de um planejamento de aula para uma disciplina $\mathrm{EaD}$, e no processo de discussão dos encontros fica evidente o movimento reflexivo e de aprendizado dos professores. As reflexões trazidas do professor Sargas, ao longo do processo, junto às mudanças nas propostas de atividades, é o que melhor ilustra essa possibilidade.

Ficou bastante evidente que os processos de mudança que ocorreram em Sargas foram resultado, inicialmente, das reflexões propostas pelos demais participantes. Isso reafirma o objetivo da colaboração, de partilha de ideias, e a possibilidade de desenvolvimento profissional. Posterior aos questionamentos, esse professor começa a demostrar uma autoconsciência a respeito do 
seu trabalho e passa, ele mesmo, a fazer questionamentos sobre como elabora as suas propostas de atividades.

As reflexões de Izar, apesar de não demonstrar mudanças em suas atividades, explicitam também o papel da "formação colaborativa". Com um desenvolvimento um pouco mais demorado, nas últimas reuniões, ele parece iniciar o mesmo caminho que Sargas percorreu já nos primeiros encontros.

A "formação colaborativa" mostrou-se eficiente como processo reflexivo, na medida em que os professores pararam para pensar sobre seu trabalho. Os processos isolados de trabalho e reflexão, que se constituíram na universidade, dificultam o trabalho dos professores e os deixam mais inseguros. A reflexão entre os pares poderia ser um espaço para o profissional falar das dificuldades, avaliar, trocar experiências e acabar com o isolamento, fortalecendo seu trabalho e, por consequência, a instituição.

A crise da sociedade contemporânea que afeta a Educação exige de instituições como a universidade respostas ou reflexões. A tarefa dos professores, seja no ensino, na pesquisa ou extensão, se complexifica. Não há receitas, é preciso refletir, discutir, mudar as práticas e avaliar as mudanças. A formação de professores pode se constituir como esse espaço reflexivo e de apoio se for pensada a partir da realidade desses sujeitos. Nesse sentido, a "formação colaborativa" coloca-se como uma perspectiva às universidades ao possibilitar reflexões e mudanças pedagógicas.

\section{Referências}

BARDIN, L. Análise de Conteúdo. Lisboa: Edições 70, 1997.

BARQUEIRO, Josana Fernandez. "O docente do ensino superior: formação, desafios e perspectivas”. In IX Congresso Estadual Paulista sobre Formação de Educadores, 2007. Formação de professores para o ensino superior. Relatos. São Paulo, 2007.

CARR, Wilfred e KEMMIS, Stephen. Teoría crítica de la enseñanza: la investigación-acción en la formación del professorado. Barcelona: Libergraf, 1988.

GIL, Antônio Carlos. Como elaborar projetos de pesquisa. São Paulo: Atlas, 1991. 
MARTINS, Mariane Denise. Processos de ensino e aprendizagem na modalidade de EaD: uma discussão a partir da compreensão de professores (dissertação). Universidade Regional do Estado do Rio Grande do Sul, 2017.

MEIRINHOS, Manuel Florindo Alves. Desenvolvimento profissional docente em ambientes colaborativos de aprendizagem a distância: estudo de caso no âmbito da formação continua (tese). Universidade do Minho, 2006.

NÓVOA, Antonio. Professores: imagens do futuro presente. Lisboa: Educa, 2009.

. Firmar a professora como posição, afirmar uma profissão docente. São Paulo, v. 47, n. 166, pp. 1106-1133, dez. 2017. Disponível em https:// bit.ly/2CBxC1Y. Acesso em: 20 out. 2017.

PETERS, Otto. A educação a distância em transição. São Leopoldo: Editora Unisinos, 2004.

POZO, Juan Ignácio. Aprendizes e mestres: a nova cultura de aprendizagem. Porto Alegre: Atmed, 2002.

RIVAS, Noeli Prestes Padilha et al. "Novos espaços formativos na universidade: desafios e perspectivas para a docência superior”. In IX Congresso Estadual Paulista sobre formação de educadores, 2007. Formação de professores para o ensino superior. São Paulo, 2007.

TEIXEIRA, Cristina Barra. "O professor como agente principal da mudança de sua prática pedagógica”. In VI Encontro de Pesquisa em Educação, Piauí, 2010. Disponível em: http://leg.ufpi.br/subsiteFiles/ppged/arquivos/files/VI.encontro.2010/GT.1/GT_01_27_2010.pdf.

VIGOTSKI, Lev Semyonovitch. A formação social da mente: o desenvolvimento dos processos psicológicos superiores. 7. ed. Trad. José Cipolla Neto, Luis Silveira Menna Barreto e Solange Castro Afeche. São Paulo: Martins Fontes, 2008. 


\title{
Especialização em agricultura familiar camponesa e educação no campo
}

\author{
A experiência do Residência Agrária na UFSM/RS
}

Carmen Rejane Flores Wizniewsky

Maiquel Ivan Rossato

\section{Introdução}

Para que se compreenda a experiência do Curso de Especialização em Agricultura Familiar Camponesa e Educação do Campo da Universidade Federal de Santa Maria, é fundamental que se conheça sua história, proposta pedagógica e estrutura, que o definem com um perfil de formação ligado à participação, intervenção e conhecimento da realidade rural, em especial nos assentamentos de reforma agrária do Rio Grande do Sul.

A ideia de criação do curso Residência Agrária, como é conhecido e reconhecido, surgiu de uma forte demanda acerca da educação do campo, nas áreas de assentamentos de reforma agrária no Brasil. Tal demanda se relaciona a uma série de questões percebidas por instituições ligadas ao viver e produzir nos assentamentos rurais, entre as quais está o Movimento dos Trabalhadores Rurais Sem Terra (MST), que, ao longo dos processos de acesso à terra, constatou a baixa escolarização, além da falta de formação em temas ligados à sustentabilidade do rural.

Diante disso, no início dos anos 1990, algumas universidades brasileiras buscaram uma aproximação à realidade no campo dos assentamentos de reforma agrária e passaram a desenvolver projetos de pesquisa, ensino e extensão, o que acabou por influenciar a formação do Grupo Interdisciplinar Básico para a Reforma Agrária. 
Tal grupo tinha como objetivo principal aproximar as universidades da temática da reforma agrária, atuando com destaque na pesquisa, o que resultou em um estudo em âmbito nacional, que buscou identificar quais universidades brasileiras vinham desenvolvendo projetos, ou ações reflexivas, sobre esse tema no Brasil.

Nesse contexto, como resposta às demandas e mobilizações dos movimentos sociais do campo, foi publicado, no ano de 1996 , o $1 .^{\circ}$ Censo da Reforma Agrária do Brasil, o qual trouxe dados de grande importância, que revelaram situações de extrema gravidade, como é o caso do alto índice de analfabetismo e baixa escolaridade nos assentados.

O Movimento dos Trabalhadores Rurais Sem Terra teve também, uma grande importância nesse processo de pensar uma educação para os assentados e seus filhos e, a partir disso, em parceria com outras entidades, realizou, em 1997, em Brasília, o 1. Encontro Nacional de Educadores e Educadoras da Reforma Agrária (ENERA). Esse evento foi de extrema importância para refletir sobre as necessidades do campo e também sobre a produção e a reprodução

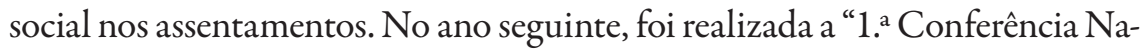
cional: por uma Educação Básica do Campo”, em Luziana, no estado de Goiás.

Nos dois eventos citados, houve uma expressiva participação dos sujeitos do campo, estes ligados ao MST, além de representantes institucionais e pesquisadores de diversas universidades do Brasil. A importante participação e o alto nível das discussões geraram uma forte repercussão em âmbito nacional, que acabou pressionando o Estado para a busca de políticas públicas direcionadas à educação e formação desses sujeitos. Como resultado dessa luta e organização, em 16 de abril de 1998, por meio da Portaria n. ${ }^{\circ}$ 10/98, o Ministério Extraordinário de Política Fundiária criou o Programa Nacional de Educação na Reforma Agrária (Pronera).

No ano de 2001, o Programa foi incorporado ao INCRA (Instituto Nacional de Colonização e Reforma Agrária), que, em parceria com Ministério do Desenvolvimento Agrário (MDA), implementou o Pronera em 2003, durante o mandato do presidente Luiz Inácio Lula da Silva. Devemos destacar que o programa surgiu a partir de uma parceria entre Governo Federal, universidades e movimentos sociais do campo.

Segundo Garcia (2007), “durante a gestão do presidente Luiz Inácio Lula da Silva (2003), articulou-se a criação dentro do MDA, de um setor para tratar especificamente dos programas de educação para a Reforma Agrária” o qual foi de grande importância para a implantação do Pronera em parceria 
com o INCRA e o MDA, quando ficou estabelecido que as universidades que já estavam trabalhando com a reforma agrária passariam a atuar na formação e capacitação dentro dos assentamentos, o que promoveu a criação de cursos como o Residência Agrária.

\section{Residência Agrária na UFSM: origem e características}

O contexto da participação das universidades nos espaços de luta dos movimentos sociais resultou em uma rica experiência de grupos de pesquisa que dirigem suas investigações e ações de extensão e ensino aos assentamentos de reforma agrária. Na UFSM, diversos grupos de pesquisa ligados a diferentes unidades administrativas, liderados por pesquisadores do Departamento de Educação Agrícola e Extensão Rural, do Centro de Ciências Rurais, se reuniram para a elaboração do projeto do curso, que desde a primeira edição passou a ser denominado de Curso de Especialização em Agricultura Familiar Camponesa e Educação do Campo, coordenado, nas duas edições, pelo professor doutor em Engenharia de Produção Pedro Selvino Neumann.

Outra questão bastante importante para que todo esse processo fosse consolidado foi a aproximação entre o Movimento Estudantil e o Movimento dos Trabalhadores Rurais Sem Terra, os quais, segundo Garcia (2007), "no âmbito desta aproximação desenvolveu-se os 'Estágios de Vivência', concebidos como formas de aproximação de atores sociais que tem mesmos objetivos de luta". Dessa forma, pode-se afirmar que os "Estágios de Vivência" foram fundamentais na criação do Programa Residência Agrária, e o Movimento Estudantil foi um dos protagonistas desse processo. ${ }^{1}$

O curso de Especialização em Agricultura Familiar Camponesa e Educação do Campo da UFSM foi resultado do convênio estabelecido a partir de um Edital entre três entidades promotoras. São elas: o INCRA, o Pronera e a UFSM. Em suas duas edições, sendo a primeira no período 2009 a 2011 e

\footnotetext{
${ }^{1} \mathrm{Na}$ UFSM, o primeiro “Estágio de Vivência” ocorreu em 1998 e foi coordenado pelo NARA (Núcleo de Apoio a Reforma Agrária). Depois dessa, outras edições ocorreram, bem como vários parceiros e colaboradores se introduziram ao processo, como o GATS (Grupo de Agroecologia Terra Sul), FEAB (Federação dos Estudantes de Agronomia do Brasil), MST e MPA (Movimento dos Pequenos Agricultores).
} 
a segunda entre 2013 e 2015, houve a participação de 100 estudantes, 50 na primeira edição e mais 50 na segunda edição.

Os estudantes que participaram do curso eram provenientes de várias entidades, incluindo assentados com nível de graduação ligados ao MST, técnicos de prestadoras de serviço aos assentamentos no Rio Grande do Sul, de projetos vinculados à UFSM e estudantes graduados em diferentes cursos, em sua maioria egressos da própria instituição de ensino superior.

Assim, cabe ressaltar que no processo seletivo para o curso existiam vagas direcionadas para cada público específico, ou seja, um determinado número de vagas para assentados, para estudantes, para os técnicos das prestadoras de serviço e projetos da UFSM e, no caso de não serem preenchidas, eram remanejadas para outro público em que o número de vagas disponibilizadas fosse menor que o número de concorrentes. Dessa maneira, nas duas edições realizadas, foram preenchidas todas as vagas disponíveis para o ingresso no Residência Agrária.

Os critérios de seleção levavam em conta o vínculo do candidato com a reforma agrária, seja por meio da prestação de serviços de assistência técnica e extensão rural ou da participação em pesquisas ou projetos de extensão realizados sobre o tema durante a sua formação, de modo que contemplasse a proposta do curso, além de possuir o perfil esperado pelos educadores e idealizadores do curso em questão.

\section{A organização pedagógica do Residência Agrária UFSM}

O curso foi planejado para ser desenvolvido por meio da Pedagogia da Alternância, o que representa a presença de momentos presenciais em aula (Tempo-Escola) e momentos em que os estudantes realizam o Tempo-Comunidade, ou seja, aplicam seus conhecimentos nos assentamentos. O programa do curso também contou com momentos de integração de conhecimentos, nas diferentes disciplinas. Isso ocorreu por meio dos trabalhos de campo em assentamentos que apresentam destaque nas questões de sustentabilidade produtiva e ambiental. Assim, várias realidades diferentes na reforma agrária do Rio Grande do Sul foram conhecidas, como pode ser observado nas fotografias a seguir. 
Figura 1: Trabalho de Campo no município de Dona Francisca-RS, 2013

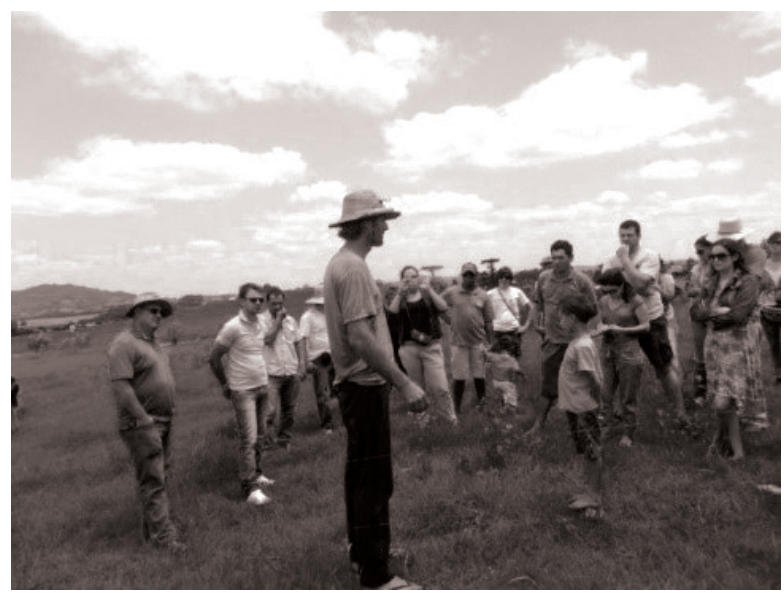

Fonte: os autores.

Figura 2: Trabalho de campo no assentamento Filhos de Sepé em Viamão-RS, 2013

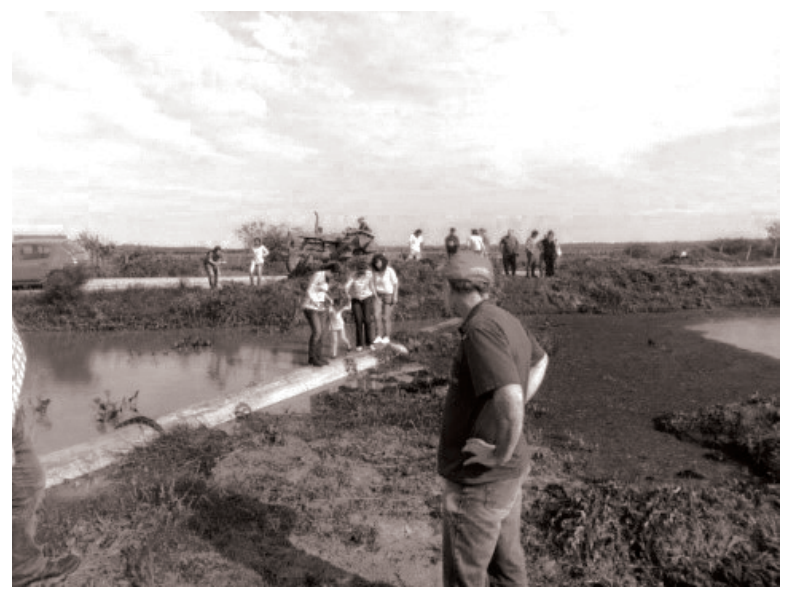

Fonte: os autores.

A primeira edição do curso, em 2009, teve duração de 18 meses, já a segunda edição, que teve início em 2013, teve duração de 24 meses. O currículo do curso compreendeu aulas presenciais, trabalhos de campo e de pesquisas que 
abordaram temas como sociedade e desenvolvimento rural, agroecologia, planejamento e gestão rural, gestão ambiental, educação do campo, políticas públicas, entre outros temas que integram toda a diversidade do campo brasileiro.

No que se refere à estrutura organizacional, o curso foi ofertado pela UFSM, com o apoio do INCRA/Pronera, e, internamente, a constituição básica do curso foi dividida em duas partes, a estrutural e a pedagógica, conforme pode ser observado na figura 3 .

Figura 3: Organograma da estrutura organizacional e pedagógica do Curso de Especialização em Agricultura Familiar Camponesa e Educação do Campo da Universidade Federal de Santa Maria

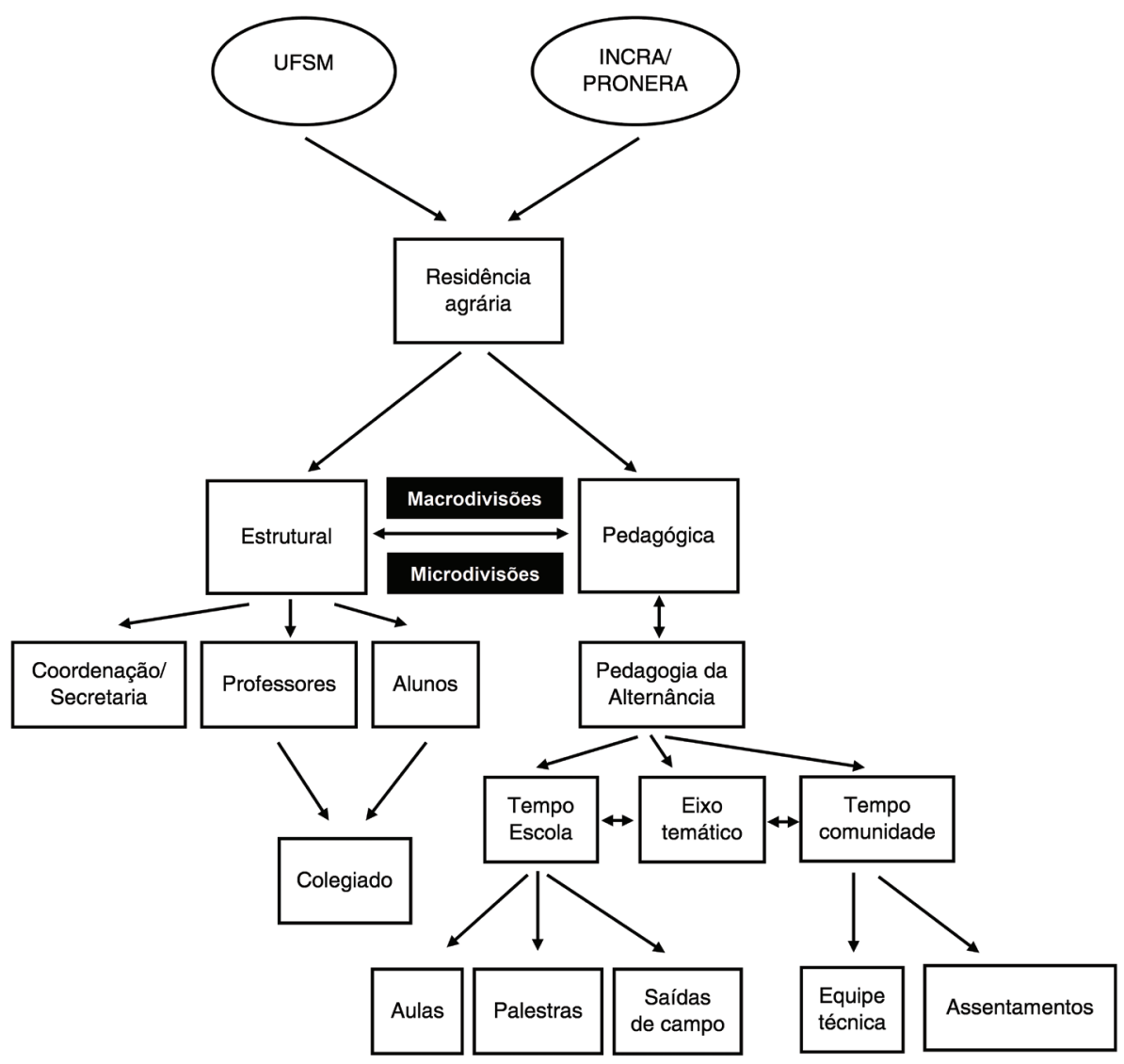

Fonte: PPP do Curso de Especialização em Agricultura Familiar Camponesa e Educação do Campo da Universidade Federal de Santa Maria, ano 2013 (modificado). 
Para a ação prática do curso, no que se refere à organização estrutural, foi organizado em quatro segmentos, e estes funcionavam de maneira integrada para atender e garantir o desenvolvimento de acordo com o projeto político-pedagógico. O primeiro segmento se refere à secretaria do curso e corpo docente, ou seja, os professores e orientadores do curso; corpo discente e o colegiado, que era formado por professores e alunos.

A secretaria do curso era responsável pelas questões burocráticas que envolviam a logística e os locais dos encontros (Tempo-Escola), controle de frequências, pagamento de diárias, transporte de alunos, professores e palestrantes convidados, entre outras atividades que deram suporte ao funcionamento do curso.

O corpo docente era responsável por ministrar as disciplinas que compõem a grade curricular, organizar as saídas de campo e orientar os estudantes nos Eixos Temáticos e nas pesquisas, as quais se consolidaram durante o Tempo-Comunidade, sobre o qual falaremos na sequência. $\mathrm{O}$ corpo discente, por sua vez, tinha a reponsabilidade de participar de forma efetiva de todos os espaços e atividades propostas durante o curso, como as aulas, saídas de campo, palestras, Tempo-Comunidade, entre outras. O colegiado do curso era a composição deliberativa e democrática onde as decisões referentes ao curso eram tomadas e aplicadas.

No que se refere à parte pedagógica, é importante esclarecer que o método de ensino utilizado foi a "Pedagogia da Alternância", a qual alterna tempo e espaço tentando aplicar e ressignificar a teoria na prática vivenciada no cotidiano de trabalho e estudo dos estudantes.

Esse método consiste na articulação entre Tempo-Escola (TE) e Tempo-Comunidade (TC). Segundo Bernartt et al.:

A Pedagogia da Alternância consiste numa metodologia de organização do ensino escolar que conjuga diferentes experiências formativas distribuídas ao longo de tempos e espaços distintos, tendo como finalidade uma formação profissional. Esse método começou a tomar forma em 1935, a partir das insatisfações de um pequeno grupo de agricultores franceses com o sistema educacional de seu país, o qual não atendia, a seu ver, as especificidades da Educação para o meio rural. A experiência brasileira com a Pedagogia da Alternância começou em 1969 no estado do Espírito Santo, onde foram construídas as três primeiras Escolas Famílias Agrícolas. 
Na primeira turma, a alternância foi desenvolvida da seguinte forma: entre quatro a cinco dias no TE e o mesmo período no TC, com o intervalo de, aproximadamente, 30 dias. Já na segunda turma, foi modificado o intervalo entre os dois espaços, ou seja, o TE e o TC, o qual foi aumentado para 45/60 dias.

\section{Conhecendo melhor o Tempo-Escola (TE) e o Tempo-Comunidade (TC)}

Nesta parte do texto, falaremos um pouco do funcionamento, das principais atividades desenvolvidas e de qual o objetivo desses dois espaços, são fundamentais na formação por alternância. Veja, na sequência, um organograma para facilitar a compreensão.

No TE, os educandos permaneciam de quatro a cinco dias em tempo integral no espaço dos encontros, os quais alternavam entre Santa Maria e centros de formação, geralmente dentro ou próximo aos assentamentos de reforma agrária de diversas regióes do RS. No TC, os estudantes iam aos assentamentos para desenvolver suas pesquisas e trabalhos anteriormente solicitados e planejados no TE; eles se integravam às equipes de assistência técnica quando, no caso, o estudante não era um técnico que já atuava em assentamentos, conforme pode ser observado na figura 4 .

Figura 4: 0 Tempo-Escola e Tempo-Comunidade

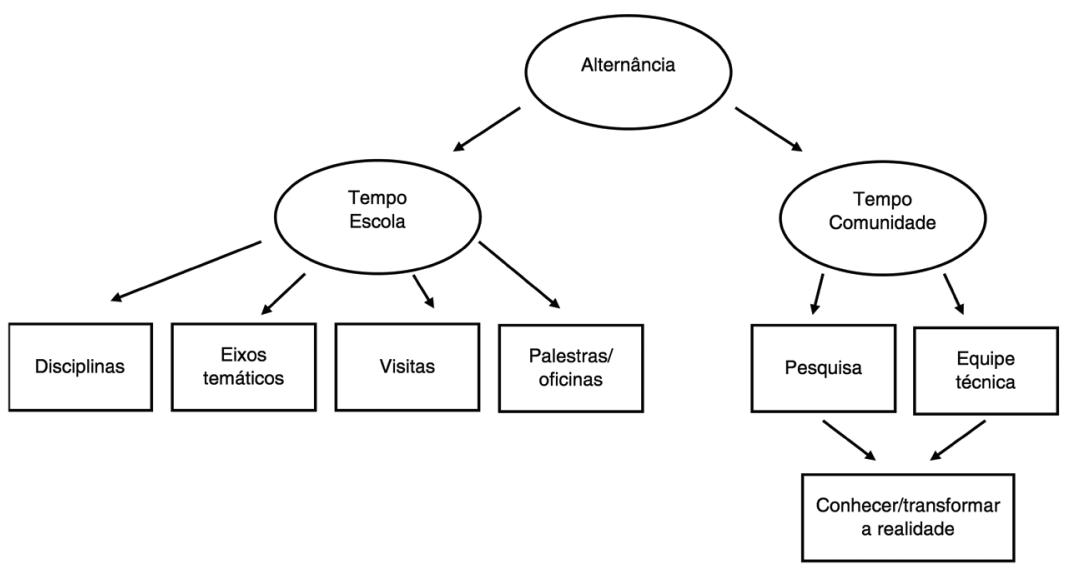

Fonte: elaborado pelos autores, a partir do PPP do curso. 


\section{Tempo-Escola (TE)}

Tempo de estudo e orientação de trabalhos de campo desenvolvidos nos centros de formação que alternavam entre UFSM/proximidades e assentamentos de reforma agrária ou proximidades.

O TE tinha como objetivo atender às exigências de multi e interdisciplinaridade às quais o curso se propunha. Nesses espaços, eram ministradas as disciplinas comuns a todos os alunos, as disciplinas específicas dos diferentes eixos do curso. Essas últimas, por sua vez, tinham como objetivo atender às demandas e interesses de pesquisa dos alunos de cada eixo temático, lembrando que tais eixos foram criados para agrupar os estudantes por afinidade do tema de pesquisa. É interessante ressaltar que na primeira turma do Residência Agrária não existiam as disciplinas dos eixos e toda a carga horária era referente às disciplinas obrigatórias e comuns a todos os alunos do curso, o que mudou na segunda turma, na qual a carga horária das disciplinas foi dividida entre disciplinas comuns a todos os alunos e disciplinas específicas de cada eixo temático.

Nesse espaço também ocorria a articulação entre os diferentes eixos temáticos, espaços de socialização e reflexão das atividades desenvolvidas durante o TC. Essa socialização/reflexão ocorria mais entre professores e alunos que faziam parte do mesmo eixo temático, uma vez que a socialização entre os diferentes eixos temáticos que compunham o curso ocorreu esporadicamente. No eixo temático, também havia a orientação e o planejamento das atividades a serem desenvolvidas durante o TC, assim como as futuras pesquisas que resultaram em monografias e artigos ao final das duas edições do curso.

Outra atividade importante foram as visitas dirigidas aos assentamentos de várias regiões do RS, as quais ocorreram de forma satisfatória, sendo organizadas pelos professores, com o apoio logístico da secretaria e coordenação do curso. As visitas sempre estavam vinculadas a uma ou mais disciplinas do curso e ocorriam, geralmente, nas etapas que se realizavam fora da UFSM e tinham como objetivo mostrar na prática situações/problema dentro dos assentamentos nas mais diversas temáticas, experiências individuais ou coletivas de produção agroecológicas, experiências de educação do campo, entre outros. Isso tudo para fomentar a reflexão e também propiciar aos estudantes um conhecimento amplo sobre os assentamentos de reforma agrária no estado do RS. 
Não podemos esquecer os espaços de formação complementar organizados pelos educandos (oficinas, palestras, etc). Todas essas atividades dentro do TE buscam permitir ao educando avançar na compreensão da problemática da sustentabilidade da agricultura camponesa de forma sistêmica, evitando a fragmentação das múltiplas dimensões do real e percebendo as potencialidades e as demandas das áreas reformadas no RS.

Durante o curso, os alunos também elaboraram propostas de monografias e artigos, sendo a modalidade de artigo aceita apenas na segunda turma do curso. As propostas foram debatidas com os orientadores e apresentadas em espaço pedagógico com a participação do corpo docente e acadêmicos do curso, visando à construção de uma perspectiva interdisciplinar e à socialização das temáticas de pesquisa entre o grande grupo.

Ao final do curso, ocorreu uma etapa só para as defesas das monografias e artigos, os quais foram apresentados publicamente a uma banca escolhida pelo colegiado do curso. Tais defesas se reservaram somente aos estudantes que tiveram aprovação em todas as disciplinas e atividades complementares previstas no projeto político-pedagógico e que cumpriram todas as exigências do regimento interno do curso de especialização.

\section{Tempo-Comunidade (TC)}

O Tempo-Comunidade é realizado pelo estudante e compreende o tempo de estudo e de trabalho desenvolvido na comunidade, ou seja, no assentamento de reforma agrária.

$\mathrm{Na}$ comunidade, são realizados estudos e pesquisas que levam a uma reflexão teórico-prática das questões pertinentes ao campo para subsidiar as intervenções práticas. As atividades são orientadas e acompanhadas por professores(as) do curso e técnicos(as) que atuam diretamente na assistência técnica dentro dos assentamentos.

O TC ocorreu em diversos assentamentos em várias regiões do estado do RS, realizado ao longo do curso entre as etapas do TE, sendo obrigatório para todos os estudantes. Tinha como objetivos proporcionar um confronto permanente entre os conteúdos das disciplinas da grade curricular e o contexto observado pelo estudante nas áreas de assentamentos, ao mesmo tempo em que por meio de temáticas originadas desse olhar sobre situações-problema encontradas nos assentamentos e que, a partir da pesquisa, se busca com- 
preender e superar essas limitações impostas. A pesquisa, por sua vez, é fundamental para instrumentalizar o futuro profissional para desenvolver ações e tomar decisões em prol da sustentabilidade econômica, social e ambiental da agricultura familiar camponesa.

A pesquisa acontece em praticamente todas as atividades do curso, seguindo cinco linhas coerentes com os eixos temáticos, partindo de problemas que envolveram: Política e Gestão Ambiental, Agroecologia, Sociedade e Desenvolvimento Rural, Políticas Públicas e Planejamento e Gestão Agrícola.

A pesquisa realizada durante o TC no assentamento foi organizada mediante os princípios da pesquisa - ação no movimento dialético do conhecimento de ação-reflexão-ação com abordagem qualitativa. Dessa forma, no âmbito da pesquisa durante o TC, foram realizados o levantamento do problema, a coleta de dados, a formulação de hipótese, experiência e problematização, a sistematização e conclusão. O TC foi de grande importância na construção das monografias e artigos pelos estudantes.

Outras atividades inerentes ao trabalho das equipes técnicas também eram realizadas ou acompanhadas pelos estudantes, tudo com a orientação e supervisão de um técnico da equipe prestadora de serviço. Tais atividades envolviam visitas técnicas, serviços de escritório, vacinação de bovinos, reuniões da equipe técnica nos assentamentos, entrega de equipamentos provenientes de políticas públicas aos assentados, entre outros.

A partir disso, o acadêmico do curso conseguiu conhecer, pelo menos de forma parcial, todas as atividades das equipes técnicas das prestadoras e visualizar as demandas e as potencialidades dos assentamentos de reforma agrária na região onde realizou o seu TC. No caso de o estudante já atuar como técnico, ele sistematizava alguma atividade para apresentar ou debater no espaço dos eixos temáticos durante o TE, trazendo, geralmente, problemas, dificuldades e anseios do seu trabalho cotidiano, buscando, no grande grupo, fomentar o debate e encontrar soluções ou alternativas para superar essas situações-problema do seu cotidiano de trabalho. Mas isso poderia variar conforme a orientação do professor orientador ou da organização dentro do eixo temático, os quais possuíam autonomia no seu funcionamento e na organização das suas atividades. 


\section{Considerações finais}

Podemos perceber, ao longo do texto, que o Residência Agrária - UFSM atua de maneira diferenciada de outros projetos de extensão desenvolvidos nas universidades, pois se fundamenta em princípios como a multi e interdisciplinaridade, buscando o desenvolvimento sustentável do campo em uma abordagem sistêmica, na qual se priorizem etapas como o planejamento, execução e avaliação do processo pedagógico por meio da metodologia da pesquisa-ação-reflexão. Tudo isso com o objetivo de fortalecer a educação do campo, a reforma agrária e construir um novo conceito de assistência técnica para os assentamentos. Mas para que isso aconteça de maneira concreta não se pode trabalhar a metodologia em separado da teoria e da realidade na qual ela está inserida.

Como pudemos perceber anteriormente no texto, todas as propostas metodológicas do Curso de Especialização em Agricultura Familiar Camponesa e Educação do Campo estão relacionadas no sentido de desenvolver processos educativos permanentes e continuados, tendo como base princípios do diálogo e da práxis que permitam o movimento de ação-reflexão-ação, que vem se demonstrando muito eficaz na transformação das realidades.

Para que isso aconteça, é fundamental que seja utilizada, nesse processo, uma dinâmica de ensino-aprendizagem que valorize e provoque o envolvimento de técnicos e agricultores assentados em ações sociais concretas e que o conhecimento científico e o conhecimento popular andem juntos e construam um conhecimento que ajude na interpretação crítica e no aprofundamento teórico necessário a uma atuação transformadora dentro dos assentamentos de reforma agrária no RS.

\section{Referências}

AGRÁRIA. Projeto politico pedagógico. Santa Maria: UFSM, 2009-2013 CAMPONESA E EDUCAÇÃO DO CAMPO-RESIDÊNCIA CURSO DE ESPECIALIZAÇÃO EM AGRICULTURA FAMILIAR. 
BERNARTT, M. de L. et al. "Estudos sobre Pedagogia da Alternância no Brasil: revisão de literatura e perspectivas para a pesquisa”. Educação $e$ Pesquisa, v. 34, n. 2, pp. 227-42, São Paulo, maio-ago. 2008.

CALDART, R. S. et al. (orgs.). Dicionário de Educação do Campo. Rio de Janeiro: Escola Politécnica de Saúde Joaquim Venâncio, São Paulo: Expressão Popular, 2012.

GARCIA, J. V. Desafios na formação de competências para profissionais de ATER em áreas de assentamentos e agricultura familiar: análise do programa Residência Agrária (dissertação). UFSM 2007.

et al. "O curso de especialização em Agricultura Familiar Camponesa e Educação do Campo II, a experiência da Universidade Federal de Santa Maria”. In WIZNIEWSKY, C. R. F. et al. (orgs.). Anais do II Seminário internacional de Educação do Campo e Fórum regional do centro sul do RS. Santa Maria, 2014.

INSTITUTO NACIONAL DE COLONIZAÇÃO E REFORMA AGRÁRIA. Disponível em: http:www.incra.gov.br/pronerahistoria. Acesso em: 5 maio 2017.

MOLINA, M. “Desafios para os educadores e as educadoras do campo". In KOLLING, E. J. et al. (orgs.). Educação do campo: identidade e políticas públicas. Brasília: Articulação Nacional por uma Educação do Campo, 2002, p. 39. (Coleção Por uma Educação do Campo, n. 4). p. 39. 


\section{Ideologia hegemônica em questão}

\section{0 rural brasileiro representado em livros didáticos do Programa Nacional do Livro Didático (PNLD - Campo)}

Lair Miguel da Silva Marcelo Cervo Chelotti

\section{Introdução}

A atual conjuntura do rural brasileiro é marcada por conflitos e desigualdades, reflexo de um passado estruturado na concentração fundiária que se intensificou com a intervenção neoliberal. Essa intervenção, caracterizada pela Revolução Verde, inserida no Brasil a partir da década de 1950, provocou graves impactos ambientais e sociais no meio rural. Apesar de entendermos que os problemas agrários brasileiros são antigos, podemos admitir que com a Revolução Verde eles se agravaram. Se, por um lado, os pacotes tecnológicos dessa revolução proporcionaram um elevado aumento da produção; por outro lado, esses mesmos pacotes provocaram o êxodo rural, desestabilizando milhares de trabalhadores, muitos dos quais, sem-terra e sem trabalho, veem como única alternativa alojarem-se nas periferias das cidades. Esses pacotes também provocam a dependência dos produtores, que se tornam reféns do grande capital.

Outros trabalhadores que resistiram ao processo de modernização do campo são obrigados a conviver com a violência daqueles que se esquecem de que o campo é um lugar de reprodução da vida e não apenas de reprodução do capital. Assim, o rural brasileiro, ou seja, as relações sociais, culturais, ambientais e econômicas existentes no campo brasileiro são conturbadas, principalmente devido à formação de territórios construídos por diferentes agentes sociais e, consequentemente, com interesses divergentes - o território 
do agronegócio e o território camponês, os quais lutam cada um pela implantação e expansão de seus ideais. Essa luta gera violência, que culmina em muitas mortes e prejuízos para trabalhadores do campo que seguem na esperança de que a justiça seja feita, uma vez que no campo a impunidade prevalece.

É nesse contexto que os povos do campo, em sua luta constante, principalmente por meio dos movimentos sociais, foram contemplados com uma política pública de reconhecimento da Educação do Campo, o Programa Nacional do Livro Didático (PNLD - Campo). Esse programa visa à distribuição de livros didáticos diferenciados para os anos iniciais do Ensino Fundamental das escolas rurais. O Programa Nacional do Livro Didático é uma das maiores políticas públicas educacionais brasileiras. Assim, acreditamos que o PNLD Campo seja um avanço para a Educação do Campo. Porém, não podemos nos esquecer de que a educação é uma das estratégias utilizadas pelo Estado para disseminar ideologias que assegurem interesses da classe dominante.

Desse modo, o presente texto, fruto da minha dissertação de mestrado, busca refletir a respeito da diferença entre o rural brasileiro real e o representado em livros didáticos do PNLD - Campo 2016, lembrando que essa diferença é produzida com base em uma ideologia hegemônica, uma vez que o Estado, fomentador dessa política pública, é um legítimo defensor da classe dominante.

Assim, estruturamos este texto em duas seções: na primeira, enfatizamos a questão da ideologia hegemônica nos livros didáticos; na segunda, abordamos a diferença entre o rural brasileiro real e o representado em livros didáticos do PNLD - Campo 2016, com base na análise de fotografias e textos presentes nesses livros.

\section{A ideologia hegemônica no livro didático}

Ao falarmos em ideologia hegemônica no livro didático, consideramos pertinente explicar a nossa concepção a respeito desse termo, uma vez que possui duplo sentido. Moraes (2005), fazendo alusão ao seu significado primitivo, afirma que essa seria a ciência da gênese das ideias, cujos resultados serviriam para um melhor ordenamento da vida social. Para Deiró, "A ideologia em geral é radicalmente ambivalente, isto é, ela poderá estar a serviço da dialética da História - explicitando as contradições - como poderá exercer uma função conservadora - camuflando as contradições objetivas" (Deiró, 2005, p. 31). Para Chaui (2008, p. 110), 
A ideologia nunca pode explicitar a sua própria origem, pois, se o fizesse faria vir à tona a divisão social em classes, e perderia, assim, sua razão social de ser, que é a de dar explicações racionais e universais que devem esconder as diferenças e as particularidades reais, ou seja, nascida por causa da luta de classes e nascida da luta de classes, a ideologia é um corpo teórico (religioso, filosófico ou científico) que não pode pensar realmente a luta de classes que lhe deu origem.

Pensando assim, em relação à concepção do termo “ideologia”, podemos considerar que temos pelos menos duas vertentes: a dos que consideram a ideologia como tendo um caráter dual ou ambivalente, conforme apontado por Deiró, e outros que a veem como um instrumento de dominação. Chaui (2008), por exemplo, nos explica que na ideologia, ou no discurso ideológico, há "brancos", "lacunas", "silêncios", que nunca poderão ser preenchidos, sob pena de destruir a coerência ideológica. Ela afirma que a ideologia é coerente justamente por causa das lacunas, ou seja, porque não diz tudo e nem pode dizer tudo, pois se assim o fizesse perderia sua função de mascarar ou de ocultar a realidade. A ideologia é um dos meios usados pela classe dominante para exercer a dominação de modo que essa não seja percebida como tal pelos dominados.

Logo, a autora nos mostra também que não é possível substituir uma ideologia "falsa" (que não diz tudo), por uma ideologia "verdadeira" (que diz tudo), sendo a primeira dos dominantes e a segunda dos dominados. Isso porque, primeiramente, uma ideologia que dissesse tudo já não seria mais ideologia. Segundo, porque "falar em ideologia dos dominados é um contra-senso, visto que a ideologia é um instrumento de dominação" (Chaui, 2008 pp. 109-10).

Desse modo, ela faz uma distinção entre ideário, "conjunto sistemático e encadeado de ideias", e "ideologia que é um ideário histórico, social e político que oculta a realidade, e que esse ocultamento é uma forma de assegurar e manter a exploração econômica, a desigualdade social e a dominação política" (Chaui, 2008, p. 7). Logo, tomamos como embasamento para este trabalho o conceito de ideologia apresentado pela filósofa, que constitui um instrumento dominador que oculta parte da realidade mascarando-a. Porque essa ideologia pertence à classe dominante, ao mencioná-la, usaremos a expressão ideologia dominante ou ideologia hegemônica.

A ideologia hegemônica rege os princípios da educação brasileira, podendo ser encontrada nas propostas curriculares, nos livros didáticos e em outros meios. Trata-se de uma estratégia utilizada pelo Estado para ocultar a luta de 
classes e assegurar a reprodução do capital. Vários estudos já foram realizados a fim de verificar a ideologia hegemônica no livro didático, e os resultados confirmam que a sua presença é considerável nesse recurso didático.

Por exemplo, Deiró (2005, p. 17) nos mostra que "As mensagens ideológicas, veiculadas por diferentes meios, entre os quais se destacam os livros didáticos, transmitem valores que não correspondem às necessidades e aos interesses da classe trabalhadora”. Essa mesma autora prossegue afirmando que "os textos de leitura dos livros didáticos das quatro primeiras séries do primeiro grau, ou seja, dos anos iniciais do ensino fundamental, transmitem uma ideologia, formulada e imposta pela classe dominante à classe dominada, como sendo a única e verdadeira visão do mundo" (p. 20).

É importante ressaltar que tanto Deiró (2005) quanto Faria (2008) constataram a ideologia hegemônica em elementos essenciais para a sociedade: a família, a escola, o trabalho. Neste último, podemos dizer que a ideologia dominante se deu de forma bem acentuada nos livros analisados pelas autoras.

Faria (2008), ao abordar como o trabalho aparece no livro didático, faz menção a uma passagem bem interessante extraída de um dos livros que analisou: “Tudo que temos é resultado do trabalho". Em seguida, ela faz os seguintes questionamentos: trabalho de quem? Quem trabalha? Para que se trabalha? Em que tipo de sociedade? O livro didático, segundo Faria (2008, p. 29), não responde a esses questionamentos.

O trabalho, forma de o homem dominar a natureza e constituir sua existência, não é visto pelo livro didático como categoria. Ele á apenas uma atividade com fim de criar valor de uso (trabalho concreto), onde o caráter subjetivo está sempre presente, tanto no que se refere às características do trabalhador, quanto a sua participação e domínio de todo processo.

Outra passagem extraída de um livro desta feita, analisado por Deiró, diz o seguinte: “O trabalho é necessário para todos, dá saúde, alegria, além de aumentar a riqueza e o bem-estar geral. Todo trabalho tem valor e o grande inimigo do trabalho é a preguiça" (2005, p. 127). A partir desse fragmento textual, podemos fazer também alguns questionamentos: será que, no modo de produção no qual estamos inseridos, que tem por princípio a exploração, o trabalho traz saúde e alegria? Mas a pergunta crucial é: o trabalho aumenta a riqueza de quem? Com certeza, aumenta a riqueza de quem detém os meios de produção, a classe dominante, mas, na sociedade capitalista, tudo depende do esforço individual. 
Segundo a ideologia subjacente aos textos de leitura è̀ estrutura escolar, em geral, cada aluno, individualmente, é responsável por seu sucesso ou fracasso escolar. Isto traduz a ideologia capitalista, segundo a qual cada indivíduo é responsável também por seu êxito sócio-econômico. A seleção social, que faz com que alguns sejam privilegiados, é camuflada pela desculpa de mérito individual (Deiró, 2005, p. 87).

Para Chaui (2008), a ideologia burguesa, por meio de seus intelectuais, produzirá ideias fazendo, por exemplo, com que os homens creiam que são desiguais por natureza ou por talento, ou que são desiguais por desejo próprio, isto é, os que honestamente trabalham enriquecem, enquanto os preguiçosos empobrecem. Ou, então, faz com que creiam que são desiguais por natureza, mas que a vida social, lhes garantindo o direito de trabalhar, concede o direito de melhorar, oculta o fato de que os trabalhadores não são donos do trabalho e que, consequentemente, as chances de melhorar não dependem deles, mas dos que detêm os meios e as condições de trabalho. Faz também com que os homens creiam que são desiguais por natureza e pelas condições sociais, mas que são iguais perante a lei e o Estado, escondendo que a lei foi feita pelos dominantes e que o Estado é um instrumento também dos dominantes.

Ainda em relação à ideologia dominante contida nos livros didáticos, Deiró chama a atenção para um aspecto que não pode passar despercebido: o modo como o rural brasileiro é apresentado nos livros didáticos.

Enquanto o texto descreve a fartura brasileira, o problema agrário no Brasil é um dos mais sérios e com poucas probabilidades de ser solucionado. É no campo que se encontra o cerne da luta de classes no país. Aí está a classe mais explorada: o proletariado rural, os textos de leitura, portanto, não descrevem a estrutura social real que existe na agricultura brasileira, constituída de diferentes classes sociais. A realidade da exploração do proletariado rural é silenciada pelos textos (2005, p. 112).

Para a classe hegemônica, representada pelo Estado, não é conveniente apresentar os problemas existentes no rural brasileiro, não se justifica falar de exploração se são os próprios atores dessa classe os exploradores.

Ao analisar livros didáticos de Geografia, Cordeiro também pôde presenciar a ideologia da classe dominante contida nesse material em relação aos mo- 
vimentos sociais do campo, quando os autores do livro analisado criminalizam a luta pela terra ao simplificarem as condições concretas e simbólicas da luta.

Os autores deixam bem claro suas escolhas ideológicas ao optarem pela categoria 'invasão' ao invés de 'ocupação', já que o primeiro termo refere-se a um ato ilegal e o segundo ganha uma conotação política de lutas por direitos negados, assim como pelo uso da expressão 'apossar'. Também usam da ironia ao criticarem os líderes que, em suas visões, tratam a luta como uma 'profissão' como se esse fato carregasse em si estigmas negativos. Para os alunos que vivem no campo estas posições ideológicas negam a necessidade de organização de movimentos sociais ao mesmo tempo que incentivam passividade, já para os alunos que vivem em acampamentos e assentamentos do MST as conseqüências são bem mais profundas já que estão possivelmente integrados na luta. Esta forma de tratar a questão pode levar aos alunos do MST até mesmo a sentimentos de vergonha e humilhação (Cordeiro, 2009, p. 34).

O certo é que nenhum livro didático, seja ele voltado tanto para a educação urbana quanto para a educação do campo, contenha essas ideologias em seu conteúdo. Todavia, como pode ser visto na citação, o efeito dessas ideologias em escolas do campo pode vir a ser mais nocivo para os educandos. Isso pode contribuir para que o aluno crie certa aversão à escola, que, por sua vez, utiliza um recurso didático em seu desfavor, levando, consequentemente, à evasão escolar desse aluno. Ou, prevalecendo a ideologia desses autores nos livros didáticos, os alunos podem passar a negar a sua condição e a luta como sujeitos do campo.

Entretanto, não são apenas os movimentos sociais que são ideologizados nos livros didáticos, pois a mulher, o negro e o índio também são representados segundo a visão burguesa, ou seja, de acordo com a ideologia dominante. Essa ideologização se faz presente nos textos, nos exercícios e até mesmo nas ilustrações, que reforçam o conteúdo ideológico que se quer transmitir. Dessa forma, corroboramos com Faria (2008, p. 77) quando ela afirma que

O livro didático não é desligado da realidade, ele tem uma função a cumprir: reproduzir a ideologia dominante. A ideologia também não é desligada da realidade, ela também tem um papel e o cumpre. O que 
ocorre é que a ideologia dominante considera a produção intelectual autônoma e desconhece a base material como instancia determinante. Então, expressa através de valores universais os interesses da burguesia e justifica a conservação das relações de produção existentes. Isto não é estar desligado da realidade, pelo contrário, através deste mecanismo, o livro didático serve à manutenção dos interesses da classe dominante ignorando os interesses da classe operária.

O problema não é que o livro didático desconheça a realidade; pelo contrário ele precisa conhecê-la para definir o que poderá ser apresentado e o que deverá ser ocultado. O livro didático também não é um "mentiroso", já que parte da ideologia de que possui um cunho verdadeiro. Diríamos que, por disseminar ideologia, o livro didático acabe sendo um material omisso, tendo em vista que deixa de mostrar a verdade por completo.

$\mathrm{Na}$ realidade, disseminar a ideologia hegemônica não é função do livro didático; a função deste recurso é auxiliar no processo de ensino e de aprendizagem. Entretanto, como o livro didático é distribuído em escala nacional, constitui para a classe dominante um excelente meio para disseminar sua ideologia, e isso acontece de forma eficiente, pois, em muitos casos, devido a uma série de fatores, o livro didático não é debatido nem criticado, ele é simplesmente reproduzido nas salas de aulas.

\section{0 rural brasileiro real e representado em livros didáticos do PNLD-Campo}

O Programa Nacional do Livro Didático (PNLD) é o mais antigo dos programas voltados à distribuição de obras didáticas aos estudantes da rede pública de ensino brasileira. Esse programa tem vivido diversos avanços em sua trajetória, contudo o livro didático não deixa de ser um objeto provocador de polêmicas. Isso porque esse recurso didático, além de apresentar fragilidades em sua principal função, auxiliar no processo de ensino e de aprendizagem, ainda exerce outras funções, entre as quais a econômica e a ideológica, causando, assim, divergências entre opiniões a seu respeito, sobretudo no meio acadêmico.

O livro didático, conforme bem nos mostram Pontuschka et al. (2009), é um recurso que apresenta múltiplos aspectos, sendo, ao mesmo tempo, uma produção cultural e uma mercadoria. Como mercadoria, o importante para 
as editoras é que ele seja vendido. Por outro lado, Martins (2014, pp. 79-80) nos mostra também que o livro didático,

como instrumento pedagógico tornou-se em alguns contextos, o principal elemento do processo de ensino e de aprendizagem. Essa evidência se dá pelo fato de que, em alguns casos, ser este um dos únicos instrumentos disponíveis para o diálogo na sala de aula. Isso pode ser observado, principalmente, em escolas em contextos periféricos, materialmente esquálidos, especialmente por não disporem de recursos financeiros para aquisição de outros materiais, ou em escolas da zona rural que dispõe de poucos recursos didáticos, além de uma infraestrutura precária em que até mesmo bibliotecas são escassas. Neste contexto, programas de distribuição de livros didáticos, como o PNLD, são responsáveis por fornecer a maior parte do material que é utilizado pelos discentes.

E, entre os programas de distribuição de livros didáticos, queremos enfatizar neste trabalho o Programa Nacional do Livro didático (PNLD - Campo), que fomenta a produção de livros didáticos para atender aos anos iniciais do ensino fundamental das escolas rurais. Com a primeira edição em 2013 e a segunda em 2016, o referido programa tem como objetivo, de acordo com o Guia de Livros Didáticos PNLD Campo 2013,

considerar as especificidades do contexto social, econômico, cultural, político, ambiental, de gênero, geracional, de raça e etnia dos Povos do Campo, como referência para a elaboração de livros didáticos para os anos iniciais do ensino fundamental (seriado e não seriado), de escolas do campo, das redes públicas de ensino. Com esse objetivo, o PNLD Campo se inscreve como uma política pública de reconhecimento da Educação do Campo como matriz referencial para pensar o Campo e seus Sujeitos, como contexto gerador de conteúdos, textos, temas, atividades, propostas pedagógicas, ilustrações, e organização curricular do livro didático (Brasil, 2012, p. 9).

De acordo com esse guia, poderiam participar desse programa as escolas situadas ou que mantêm turmas anexas em áreas rurais e estivessem vinculadas às redes de ensino estaduais, municipais e federais, que tivessem firmado termo de adesão ao PNLD. Seriam atendidas pelo PNLD - Campo 2013 as 
escolas rurais com até 100 alunos matriculados nos anos iniciais do ensino fundamental e as escolas rurais com mais de 100 alunos que não realizaram a escolha do PNLD 2013 ou que tenham optado por não receber livros naquele programa.

Conforme disposto no Guia, o PNLD - Campo foi projetado visando atender às especificidades da Educação do Campo, com o intuito de superar as obras já existentes, mas que se mantinham alheias às Diretrizes Operacionais formuladas pelo Conselho Nacional de Educação para a Educação Básica das Escolas do Campo.

Vimos que o PNLD - Campo é um programa voltado para a população do campo, mas qual rural brasileiro é representado nos livros desse programa? O real ou o ideologizado? Foi a partir dessa inquietação que surgiu o interesse de analisarmos fotografias e textos presentes em livros didáticos desse programa. Utilizando as metodologias iconográfica e iconológica que se baseiam, respectivamente, na descrição e na interpretação de imagens, analisamos algumas fotografias de livros do $4 .^{\circ}$ e do $5 .^{\circ}$ ano, bem como os textos que as seguem. Assim, escolhemos três das fotografias analisadas para dar suporte a este trabalho.

A primeira fotografia faz parte do capítulo quilombolas do Vale do Ribeira. Na parte textual, são feitas algumas perguntas sobre o que é uma comunidade quilombola e como é o seu modo de vida: você sabe o que é mutirão? Já participou de algum? Existem mutirões em sua comunidade? Que vantagens podem existir em uma comunidade se organizar dessa forma? $\mathrm{Na}$ foto a seguir, o que as pessoas parecem estar fazendo em mutirão? Após as perguntas, é disposto um conteúdo explicando o que vem a ser um mutirão e a fotografia representando o trabalho em mutirão no Vale do Ribeira.

Quando todos ajudam a construir a casa de uma pessoa, por exemplo, essa pessoa se compromete a ajudar a construir casas para os outros. Ou seja, mutirão é quando várias famílias da comunidade se reúnem para ajudar na construção, na colheita ou na plantação de um dos moradores. Em troca esse morador vai ajudar os outros quando precisarem. No final do mutirão quase sempre tem uma comemoração, com muita comida para todos (Brait Junior et al., 2014, p. 9).

$\mathrm{Na}$ fotografia a seguir, podemos ver as pessoas trabalhando em sistema de mutirão em uma comunidade no Vale do Ribeira, localizado entre o sul 
do estado de São Paulo e o leste do Paraná. A fotografia é composta por dez pessoas, entre homens, mulheres e crianças. Duas mulheres e uma criança estão em posição de movimento, trabalhando, enquanto as outras pessoas estão paradas. As pessoas que compõem a fotografia parecem sérias e compenetradas, sem agitação. As mulheres que estão capinando parecem preparar o solo para o plantio. Há uma cerca (os postes são bem visíveis) separando o lugar onde o pessoal está e uma mata. Uma das crianças está sem camisa e descalça. Outro detalhe importante é que metade da fotografia mostra um céu azul com algumas nuvens brancas. Em geral, as cores azul e branca simbolizam paz, tranquilidade e harmonia.

Figura 1: Trabalho em mutirão no Vale do Ribeira - 4..$^{\circ}$ e $5 .{ }^{\circ}$ anos

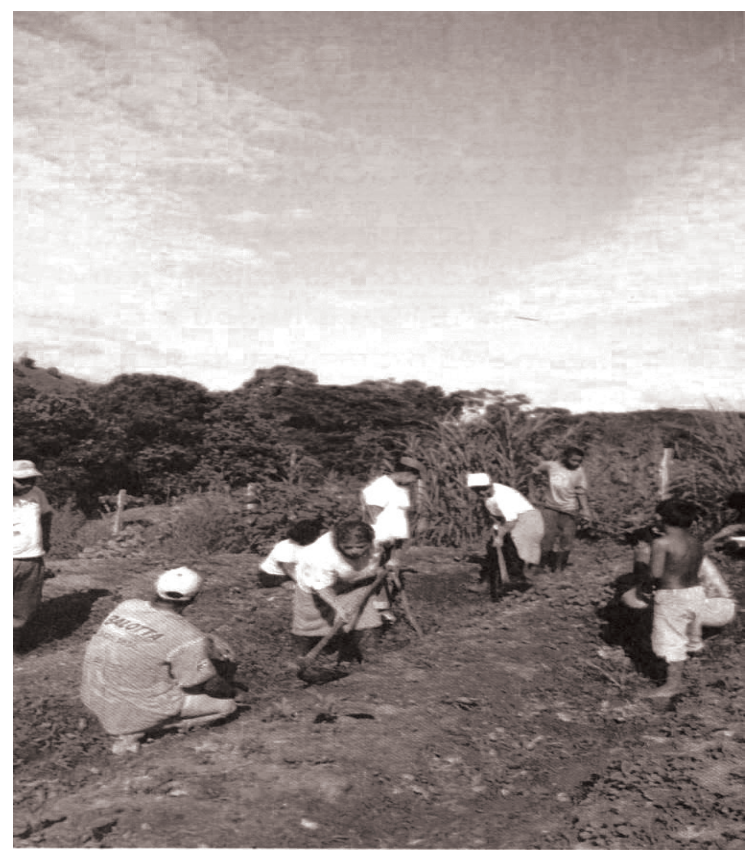

Fonte: Brait Junior et al., 2014.

Ao passarmos para a interpretação, podemos ver que tanto a fotografia quanto o texto que a acompanha estão mostrando que o mutirão é uma forma de trabalho eficiente, na qual reina principalmente a comunhão. Diría- 
mos que aqui reside um importante significado do rural brasileiro expresso no livro didático, ou seja, as comunidades quilombolas estão estáveis, uma vez que possuem uma excelente forma de trabalho, o mutirão, por meio do qual elas conseguem construir moradias, realizar o roçado, o plantio e a colheita do arroz, do feijão, do milho, etc.

O quilombo recupera o comunitarismo de tradição africana. Assim ninguém é dono da terra ou das ferramentas; todos trabalham juntos, em mutirão, para construir a comunidade, para abrir e manter os caminhos e também para se dividir na produção de alimentos. A solidariedade é uma característica dos quilombo (Brait Junior et al., 2014, p. 10).

Os autores até chegam a falar das restrições em relação ao uso da terra que essas comunidades tiveram em consequência da criação de unidades de conservação ambiental, com o objetivo de compensar os anos de devastação da Mata Atlântica. Todavia, em nenhum momento é abordada a questão da terra, por exemplo, das dificuldades enfrentadas por muitas comunidades quilombolas para obter a titulação.

$\mathrm{O}$ arroz e o feijão cultivados pelos quilombolas sempre foram a base da alimentação das comunidades. No entanto, a partir da década de 1950, a prática agrícola tem diminuido devido a construção da rodovia na região do Vale do Ribeira, às restrições ambientais impostas pelas unidades de conservação e a oferta de trabalho assalariado em propriedades vizinhas. Isso tudo compromete a cultura quilombola, pois muitas de suas práticas estão diretamente ligadas à agricultura (Brait Junior et al., 2014, p. 27).

A dificuldade de acesso à terra se resume em uma questão cultural - o econômico não é levado em consideração. Aliás, o próprio mutirão é visto apenas sob uma perspectiva cultural. Consideramos o mutirão uma prática importantíssima, mesmo porque ela possui um caráter bem humanitário. Por outro lado, não podemos desconsiderar o econômico. O mutirão, muitas vezes, é realizado não apenas por uma questão cultural, mas também porque o beneficiado não tem condições financeiras para pagar pelo serviço.

Ainda podemos ver na citação que um dos motivos da diminuição da prática agrícola é a oferta do trabalho assalariado em propriedades vizinhas. Isso nos leva a imaginar que, se as pessoas deixam suas terras e vão trabalhar em 
outras propriedades, é por quenão estão conseguindo produzir o suficiente para satisfazer suas necessidades. E por que não estão conseguindo produzir? Que tipo de problema estão enfrentando?

Acreditamos que há algo errado, e, apesar de o trabalho em mutirão ser uma excelente alternativa para as comunidades quilombolas, pois é da lógica camponesa a reciprocidade, ainda há muitos problemas ocultos pelo livro didático. Por exemplo, na fotografia aparecem mulheres e crianças trabalhando, mas, a exploração, a discriminação, a opressão e a violência que sabemos existir no universo feminino e infantil parecem não existir nas comunidades quilombolas.

A segunda fotografia (figura 2) faz parte do capítulo "comunidade: sujeitos coletivos". Na parte textual, as autoras afirmam que somos responsáveis pelo desenvolvimento do país, por fazer com que nossos direitos sejam respeitados e nossas culturas valorizadas. Segundo elas, com as nossas ações do dia a dia, podemos contribuir para criar o futuro de maneira diferente. As autoras explicam também que as histórias do campo e da cidade são construídas pelas pessoas que lá habitam, trabalham e produzem culturas. Abordam ainda que, nos campos brasileiros, existem muitos sujeitos coletivos, grupos sociais organizados com um jeito próprio de viver e fazer a história.

Figura 2: Assentados do MST em Eldorado dos Carajás, 1998

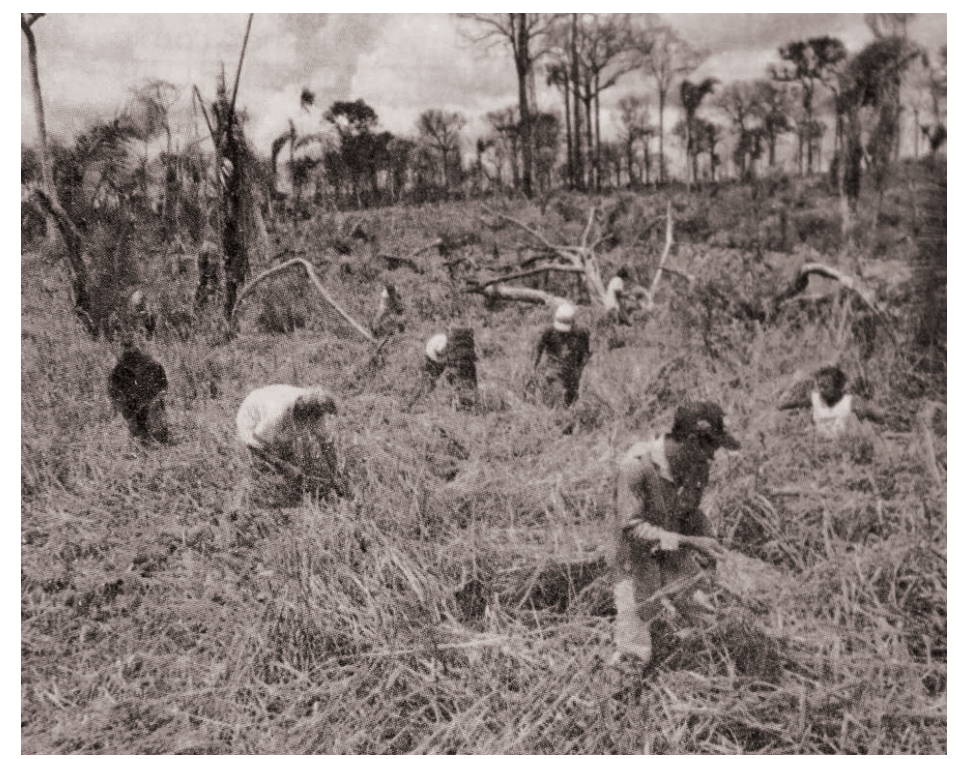

Fonte: Carpaneda et al., 2014. 
A fotografia representa os assentados do MST em Eldorado dos Carajás. Nela, é possível ver um grupo de pessoas, homens e mulheres, colhendo arroz. Há também galhos secos de árvores e outro tipo de vegetação em segundo plano. $\mathrm{O}$ arroz é um dos alimentos essenciais nas refeições de muitos brasileiros, por isso, a importância do seu cultivo. Geralmente, a colheita manual, como a representada na fotografia, é feita utilizando-se um cutelo com o qual o trabalhador vai juntando os pés de arroz e cortando.

Se olharmos tanto para a mensagem textual quanto para a fotografia, podemos constatar que tudo parece certo. Significa que esses assentados estão bem, visto que estão colhendo o que plantaram. Todavia, como este capítulo faz parte da disciplina de História, consideramos pertinente voltar um pouco no tempo. Observe que a fotografia é de 1998, dois anos após um dos mais terríveis massacres ocorridos no campo brasileiro. Resultado da luta pela terra, o saldo do massacre foi de 21 assassinatos, além dos feridos. Hoje, 22 anos após o massacre, militantes do MST ainda clamam por justiça diante da impunidade.

O massacre de Eldorado dos Carajás é algo que, a nosso ver, deveria estar presente não só na história dos povos do campo, mas também na história do Brasil, pois demonstra de forma bem evidente a violência e a barbárie no campo brasileiro, bem como a impunidade. Registrar esses acontecimentos no livro didático é importante porque os sujeitos sociais do campo vão "se (re) afirmar a partir desses episódios para darem continuidade a própria luta e existência na possibilidade da (re)criação enquanto sujeito e classe social". (Feliciano, 2016, p. 83). Além disso, não podemos negligenciar o fato de que o dia 17 de abril é considerado o Dia Nacional de Luta pela Reforma Agrária justamente devido ao massacre de Eldorado dos Carajás.

Entretanto, o livro didático se omite em dizer essas verdades. É melhor esquecer o passado sujo, sangrento, e mostrar apenas os sujeitos da história trabalhando, colhendo o seu arroz. O livro didático negligencia não mostrando essa realidade, ou seja, se omite não mostrando o Brasil que, segundo Feliciano (2016), mata e manda matar, ameaça e manda ameaçar, expulsa e manda expulsar, destrói e manda destruir, envenena e manda envenenar. Enfim, o Brasil do atraso, que, pactuado numa aliança nefasta entre capital, Estado e proprietários de terra, gera e mantém o controle territorial. O livro didático desconsidera que "lidar com o tema da posse e uso da terra é se aproximar de conflitos, injustiças, massacres traições, expropriaçóes, danos ao meio ambiente, entre outros" (Rocha, 2014, p. 45). 
A terceira fotografia (figura 3) faz parte do capítulo "O trabalho no campo”. Esse capítulo inicia-se mostrando a diferença entre o trabalho manual e o trabalho mecanizado. A fotografia mostra a parreira de uvas e uma enorme máquina na qual se encontra um homem, por certo trabalhador, que vai a controlando na colheita das uvas.

Figura 3: Colheita mecanizada da uva, 2011

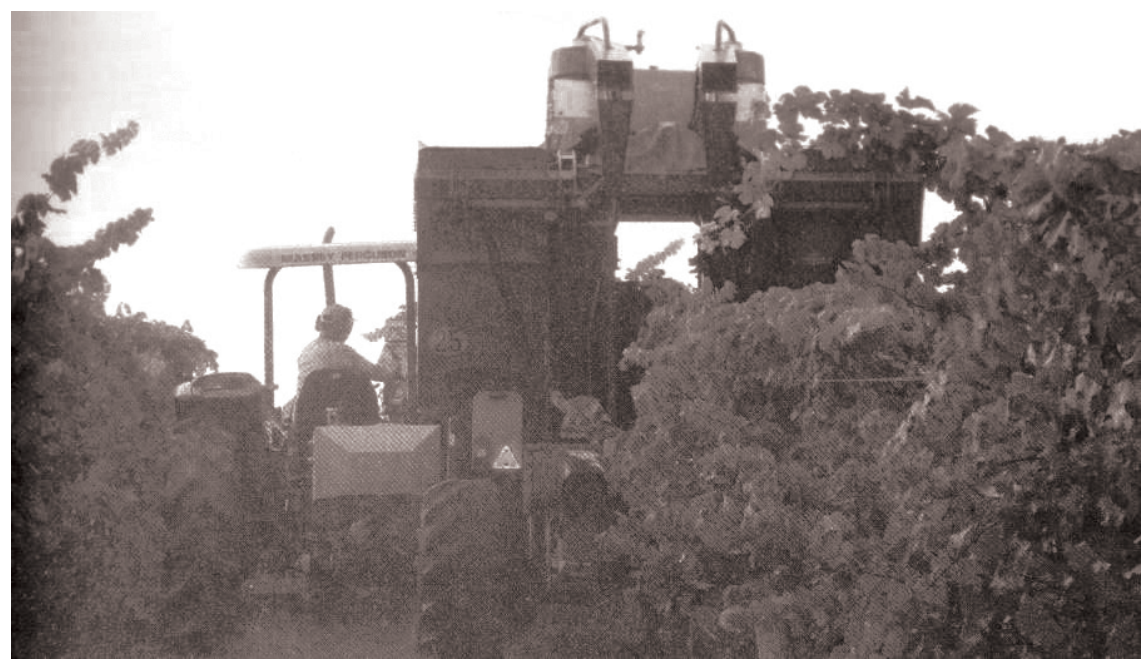

Fonte: Mendonça et al., 2014.

As autoras apresentam um texto jornalístico no qual é explicado o processo da colheita mecanizada da uva. 


\section{Colheita mecanizada da uva agiliza o trabalho nos parreirais no RS}

Uma máquina possibilita a colheita da fruta nos dois lados da espaldeira. Em 14 horas de trabalho épossivel colher até 80 mil quilos de uva.

[...] É época de colheita nas parreiras de Santana do Livramento, na fronteira do Brasil com o Uruguai. A luminosidade intensa no sul gaúcho, por causa dos dias mais longos, garante uvas doces e com mais cor.

Nos vinhedos, uma nova estratégia está chamando a atenção. Uma máquina comprada na França possibilita que a uva seja colhida dos dois lados da espaldeira. Em 14 horas de trabalho é possível colher até $80 \mathrm{mil}$ quilos de uva.

Para que o equipamento pudesse ser usado, primeiro houve uma mudança nos vinhedos. Duzentos hectares foram adaptados e deixados mais altos para se adequarem ao tamanho da máquina, que abraça folhas e frutas para fazer a colheita.

O processo é muito rápido. Para encher os dois tanques, onde podem ser armazenados 2,4 mil quilos, o trabalho é feito em dez minutos.

"Como nós trabalhamos com 22 variedades de uva, para cada variedade é feita uma regulagem. A máquina tem um computador que é facilmente regulável. A gente faz todos os ajustes na primeira hora da manhã e acompanhamos a colheita, conseguindo os ajustes dos ventiladores para retirar as folhas, para conservar mais o suco, para não romper tanto o grão. Nós conseguimos fazer todas essas regulagens para conseguir a colheita ideal que a gente quer", explicou o agrônomo.

Disponível em: http://gl.globo.com/economia/agronegocios/noticia/2011/03/colheita-mecanizada-da-uva-agiliza-0-trabalho-nos-parreirais-no-rs.html. Acesso em: 30 mai. 2014 (adaptado).

Fonte: Mendonça et al., 2014.

O texto nos mostra, com muito fervor, a eficiência da máquina na colheita da uva. A modernização da agricultura proporcionou, ao mesmo tempo, um aumento significativo da produção e diminuiu os custos com a redução no quadro de trabalhadores. Observe que, para executar todo esse trabalho, vimos apenas um trabalhador. Mesmo que haja mais pessoas envolvidas, po- 
demos dizer com certeza que não chega a ser a terça parte da quantidade de pessoas que exerciam essa função antes da chegada da máquina.

As autoras afirmam que a mecanização de muitas propriedades rurais no Brasil elevou a produção de alimentos. Por outro lado, esse processo tem gerado muito desemprego, visto que uma máquina pode executar o trabalho de várias pessoas ao mesmo tempo. Afirmam também que a mecanização não garante alimento para toda população porque, muitas vezes, a produção se destina somente ao comércio com as cidades, e não ao abastecimento da região.

Aqui, encontram-se dois importantes significados: o primeiro é que a mecanização ou a modernização da agricultura aumentou a produção de alimentos. Todavia, não podemos nos esquecer de que os protagonistas da mecanização da agricultura estão muito mais interessados na produção em grande escala, com as commodities agrícolas, tais como o milho, a soja e a cana de açúcar, do que com a produção de alimentos para abastecimento do mercado interno. $\mathrm{O}$ foco do agronegócio são as exportações. Assim, querer justificar a mecanização com a produção de alimentos não passa de uma falácia. "Contraditoriamente, temos um Brasil moderno que é exposto pelo Estado e pela grande mídia como grande potencial produtor de 'alimentos', porém, de fato, um grande produtor de commodities” (Feliciano, 2016, p. 97).

Com a modernização da agricultura, vários alimentos realmente se tornaram mais acessíveis. Entretanto, devemos nos lembrar de que a modernização provocou também o uso abusivo de fertilizantes, agrotóxicos e outros insumos. Assim, os alimentos - carnes, verduras, frutas, leite e seus derivados - diminuíram drasticamente de qualidade. Isso mostra que a população ganhou com a "diminuição" do preço dos alimentos, mas perdeu com o agravamento de muitas doenças, inclusive o câncer.

O outro significado está relacionado à substituição do homem pela máquina. As autoras afirmam que a mecanização da produção tem gerado muito desemprego no campo. É como se de uma hora para outra começassem a aparecer maquinários fantasmas no campo substituindo o trabalho humano. "A causa do grave problema social do desemprego é atribuída única e exclusivamente aos robôs” (Deiró, 2005, p. 141). A mecanização da agricultura é a culpada pelo êxodo rural, mas quem proporcionou a mecanização? Com qual intuito? O livro didático não dá explicações a esse respeito.

O texto disposto no quadro apresenta ainda outro detalhe que nos chama a atenção: "uma máquina comprada na França". Isso nos mostra a dependência da agricultura brasileira em relação ao mercado externo. Segundo 
Alentejano (2012), o processo de modernização implicou um crescente controle das transnacionais do agronegócio sobre a agricultura brasileira, seja pela determinação do padrão tecnológico (sementes, máquinas e agroquímicos), seja pela compra/transformação da produção agropecuária entretanto, o livro didático não aborda essa dependência. Alguns pontos negativos da modernização até são apontados, por exemplo o desemprego provocado mediante a inserção de maquinários no campo, todavia os atores hegemônicos responsáveis pela modernização não aparecem. É como se os processos de modernização acontecessem naturalmente sem a intervenção humana.

A quarta fotografia (figura 4) representa escolas urbanas e rurais. Apesar de ter quatro imagens, na análise consideramos o conjunto como sendo apenas uma fotografia. Esse agrupamento de fotografias faz parte da unidade intitulada "Escola para todos".

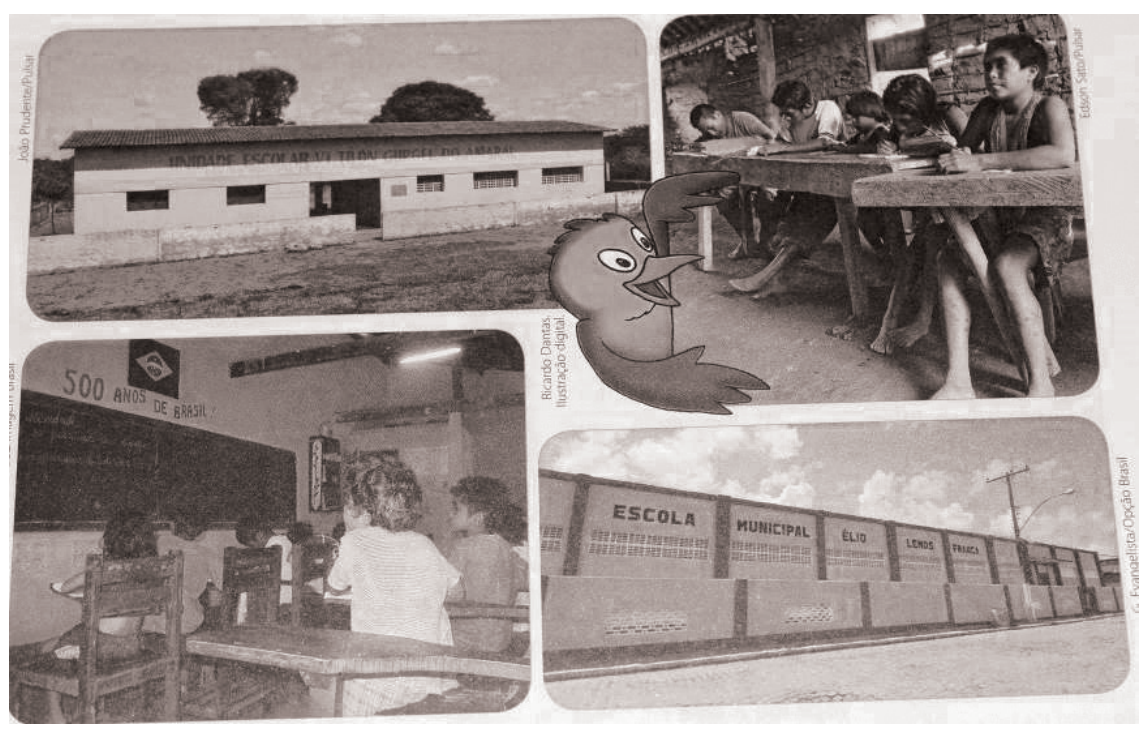

Fonte: Carpaneda et al., 2014.

Nesse agrupamento, duas fotografias correspondem a uma escola situada no campo, mostrando seu interior e exterior, e as outras duas correspon- 
dem ao mesmo, porém, representam uma escola situada na cidade. As quatro fotografias são de autorias diferentes, o que deixa certa dúvida se são duas ou quatro escolas diferentes. As fotografias também não possuem local nem data.

A fotografia que representa a escola da cidade, mostrando a parte externa, fornece vários elementos, como rua, calçada, poste de iluminação, enquanto a parte externa da escola do campo não tem esses elementos visíveis, mas deixa sobressair uma vegetação bem típica de espaço rural.

Ao adentramos nas escolas, ou seja, ao observarmos a parte interior, podemos notar também certa disparidade quanto à construção. Na escola da cidade, podemos ver a luminária, a lousa e a parede pintada. Já a escola rural apresenta uma parede sem pintura e de taipa, que é uma técnica construtiva antiga que consiste no entrelaçamento de madeiras verticais fixadas no solo, com vigas horizontais, geralmente de bambu amarradas entre si por cipós, que, depois de preenchidos com barro, se transforma em uma parede. Podemos constatar ainda uma perceptível diferença no mobiliário: as carteiras da escola da cidade possuem um modelo mais polido e são envernizadas, enquanto as carteiras da escola do campo possuem um estilo mais rústico. O grupo de alunos da escola da cidade parece ser mais heterogêneo, enquanto o grupo da escola rural parece ter predominância indígena. Neste último grupo, os alunos estão descalços, talvez por uma questão cultural, e um dos alunos veste um colar.

Ao passarmos para a interpretação iconológica, unindo os dados iconográficos com o atual contexto do rural brasileiro, podemos destacar ao menos três importantes significados: o primeiro deles é que a cidade é melhor que o campo ou a escola da cidade é melhor que a escola do campo. Dizemos isso principalmente porque é comum muitas escolas rurais brasileiras não disporem nem mesmo bens essenciais como energia elétrica e abastecimento de água.

Ao analisarmos a estrutura das escolas, é notável a preferência do poder público à educação da cidade em detrimento à educação do campo. Essa preferência do Estado está, sobretudo, vinculada ao projeto que se tem de campo, ou seja, um campo não marcado por escolas, crianças, enfim, uma comunidade, mas um campo livre para a expansão das commodities agrícolas.

O segundo significado é que há escolas tanto no campo quanto na cidade, ou seja, há escola para todos. Esse significado é, a nosso ver, o mais preocupante, uma vez que não passa de uma camuflagem para encobrir a dura realidade que as escolas rurais vêm enfrentando nos últimos tempos: o seu fechamento. 
Mesmo com o parágrafo acrescentado pela Lei n. ${ }^{\circ} 12.960$, de 27 de março de 2014, ao artigo 28 da Lei de Diretrizes e Bases da Educação - 1996 (LDB), visando a diminuir o fechamento das escolas rurais, pode-se dizer que muitas escolas ainda estão sendo fechadas. Tal acontecimento não ocorre por acaso, apesar de as justificativas apontarem o custo para mantê-las com um pequeno número de alunos. $\mathrm{O}$ certo é que, se os atores do agronegócio têm um projeto de campo com pessoas apenas para trabalhar nas atividades que o agronegócio exige, um dos caminhos a serem seguidos realmente é o fechamento dessas escolas.

Com o fechamento, os filhos estudantes terão que migrar para a cidade se quiserem continuar estudando, e, em muitos casos, os pais terão de acompanhá-los, deixando, assim, o campo livre para a expansão do agronegócio e, consequentemente, para a reprodução do capitalismo juntamente com suas contradições, injustiças e desigualdades.

É preciso lembrar também que a escola no campo não é apenas um lugar onde se ensina e aprende, mas sobretudo o lugar que mantém a unidade de determinada comunidade. Geralmente, a escola é o ponto de referência, é onde ocorrem reuniões, festas, etc. Assim, fechar uma escola do campo é uma forma de desestruturar a comunidade rural.

O terceiro significado está relacionado à cultura indígena, ou seja, essa cultura está sendo considerada na escola. Isso é muito positivo, entretanto precisamos nos atentar para o fato de que a cultura indígena não se resume a andar descalço ou usar colar. E aqui paira uma dúvida que ficará para nossa reflexão: até que ponto está sendo considerada a cultura indígena nas escolas brasileiras, se em pleno século XXI, a Funai (Fundação Nacional do Índio), responsável por defender os interesses indígenas, com quase cinquenta anos de existência, nunca teve permissão para ter uma liderança indígena?

Enfatizamos a cultura indígena porque são os seus aspectos que aparecem na fotografia analisada, entretanto, há outras culturas, como a dos povos de matriz africana, que também têm sido consideradas nas escolas apenas "superficialmente". Na visão capitalista realmente essas culturas devem ser consideradas assim porque, caso contrário, seria dificultoso explicar o porquê de muitos povos com riquíssimos saberes estarem às margens da sociedade. Teriam que explicar as contradições do capital, e isso nunca foi viável para o modo de produção capitalista.

A partir dessa fotografia, principalmente se considerarmos o título da unidade - "Escola para todos" -, podemos constatar que algo está sendo ce- 
lebrado, ou seja, há escolas para todos tanto no campo quanto na cidade, e a cultura indígena está presente nelas. Todavia, os reais problemas relacionados à educação no/do campo ficaram ocultos.

O rural brasileiro, representado em livros didáticos do PNLD Campo, difere do rural real, uma vez que os idealizadores dos livros didáticos desse programa, certamente influenciados por atores hegemônicos, se "esquecem" de mostrar os problemas existentes no rural brasileiro, ou seja, abordam os quilombolas, mas não mencionam o burocrático processo de titulação de terras e também não mencionam as ameaças e a violência que esses e outros povos do campo enfrentam na luta pela terra. Mostram assentados do movimento social trabalhando, colhendo arroz, mas deixam de mencionar um importante fato histórico: o massacre de Eldorado dos Carajás. Isso mostra que o rural do livro didático é bem diferente do rural brasileiro, injusto e sangrento.

O livro didático engrandece a modernização do campo, valorizando, sobretudo, o agronegócio, aborda timidamente o desemprego e o êxodo rural, mas se "esquece" completamente de abordar questôes como o uso abusivo de agrotóxicos na agricultura, nocivos tanto à humanidade quanto à natureza em geral. Escola para todos é o que dizem os idealizadores dos livros didáticos do PNLD Campo, todavia o intenso fechamento de escolas rurais brasileiras ocorrido nos últimos tempos inexiste na visão desses atores.

\section{Considerações finais}

Diante dos exemplos abordados neste texto, vimos com muita clareza que o rural representado no livro didático difere do rural brasileiro real. Isso se deve à ideologia hegemônica, o que significa que, parte da realidade fica oculta, não é mostrada. Pode parecer difícil compreender o porquê de uma política pública voltada para os povos do campo, o PNLD - Campo, não considerar e abordar os problemas do rural brasileiro. A verdade, no entanto, é que seria dificultoso fazer essa abordagem, uma vez que o Estado que fomenta a produção de livros desse programa é o mesmo que apoia os atores hegemônicos, dificultando o processo de titulação das terras quilombolas; fornece subsídios para o agronegócio; disponibiliza as Forças Armadas para massacrar movimentos sociais e apoia o fechamento de escolas rurais. Desse modo, na visão dos dominantes, é melhor o livro didático ser omisso, não mostrando as barbáries e atrocidades por eles cometidas no rural brasileiro. 
Contudo, precisamos entender que uma política pública não é um favor, é resultado de lutas e reivindicações, apesar de termos a certeza de que o desejo dos povos do campo é ter seu próprio material didático, e não um material idealizado pela classe dominante, como o PNLD - Campo, o certo é que "não podemos jogar a criança fora com a água do banho", como diz o ditado popular. Apesar de parecer contraditório, esses livros podem, sim, ser utilizados nas escolas rurais. Embora a nossa vontade seja a de fazer igual ao professor Keating, no filme "Sociedade dos poetas mortos", ou seja, mandar os alunos rasgarem as páginas do livro por não estarem de acordo com o que deveria ser ensinado, acreditamos não ser esse o caminho mais apropriado, pois se fôssemos agir como este professor, teríamos de rasgar o livro todo, já que a ideologia presente em tais obras é, muitas vezes, dissimulada, e perderíamos a chance de mostrar e discutir com os alunos a influência da ideologia hegemônica na educação por meio do Estado.

Assim, nesse caso, acreditamos que professor precisa, sobretudo, estar preparado para mostrar aos alunos a face da realidade que foi ocultada no livro didático, ou seja, mostrar a presença acentuada da ideologia dominante, nascida da/e por causa da luta de classes, conforme nos mostra Chaui (2008), uma vez que essa ideologia contribui para manter a exploração econômica, as desigualdades sociais e a dominação política em nossa sociedade.

\section{Referências}

BRAIT JUNIOR, Roberto et al. Cultura e regiões do Brasil: $4^{\circ}$ e $5^{\circ}$ anos. São Paulo: Global, 2014.

BRASIL. Guia de Livros Didáticos: PNLD Campo 2013. Brasília: Ministério da Educação, 2012.

CARPANEDA, Isabella Pessoa de Melo et al. Novo girassol: saberes e fazeres do campo - $4^{\circ}$ ano. São Paulo: FTD, 2014.

. Novo girassol: saberes e fazeres do campo $-5^{\circ}$ ano. São Paulo: FTD, 2014.

CHAUI, Marilena de Sousa. O que é ideologia. São Paulo: Brasiliense, 2008.

CORDEIRO, Tássia Gabriele Balbi Figueiredo. "Ensino de geografia, educação rural e educação do campo: modernidade, subalternidade e resis- 
tência”. Tamoios, ano V, n. 2, 2009. Disponível em: https://goo.gl/XSQTJ6. Acesso em: 16 abr. 2016.

DEIRÓ, Maria de Lurdes Chagas. As belas mentiras: a ideologia subjacente aos textos didáticos. São Paulo: Centauro, 2005.

FARIA, Ana Lúcia G. de. Ideologia no livro didático. São Paulo: Cortez, 2008.

FELICIANO, Carlos Alberto. "A prática da violência no campo brasileiro do século XXI”. In RAMOS FILHO, Eraldo da Silva et al. (orgs.). A questão agrária e conflitos territoriais. São Paulo: Outras Expressões, 2016, pp. 81-100.

MARTINS, Maria de Fátima Almeida. "Por uma diversidade cultural camponesa no PNLD Campo”. In CARVALHO, G.T. e MARTINS, M. F. A. (orgs.). Livro didático e educação do campo. Belo Horizonte: Faculdade de Educação da UFMG, 2014, pp. 77-92.

MENDONÇA, Márcia Rodrigues de Souza et al. Lingua Portuguesa, Geografia e História - $4^{\circ}$ ano. São Paulo: Global, 2014. (Coleção Campo Aberto).

. "Língua Portuguesa, Geografia e História - 50 ano". São Paulo: Global, 2014. (Coleção Campo Aberto).

MORAES, Antonio Carlos Robert. Ideologias geográficas. São Paulo: Annablume, 2005.

ROCHA, Maria Isabel Antunes. "O campo e seus sujeitos: desafios para os livros didáticos na educação do campo”. In CARVALHO, G. T. e MARTINS, M. de F. A. (orgs.). Livro didático e educação do campo. Belo Horizonte: Faculdade de Educação da UFMG, 2014, pp. 35-52.

SILVA, Lair Miguel da. Significados ideológicos do rural brasileiro em fotografias do Programa Nacional do Livro Didático (PNLD - Campo) 2016 (dissertação). Universidade Federal de Uberlândia, 2017. 


\title{
CAPÍTULO 22
}

\section{Como viver junto}

\section{Um estado iminente dos dispositivos de arte na atualidade e seu ensino}

\author{
Rogerio Vanderlei de Lima Trindade
}

As relações humanas e suas ações em torno da sociedade constituem o centro temático pesquisado por um grande número de artistas, no decurso da produção de imagens. Essas imagens registram a maneira como o homem se insere, reflete e se projeta no universo sociocultural.

Essa historiografia imagética representa um sistema dinâmico, usando elementos abstratos para viabilizar o recorte percebido por quem a concebe, dentro da cultura material. Aristóteles, tal como nos faz lembrar Jacques Aumont (1993, p. 200), já dizia que as imagens são projeções mentais sensíveis concebidas pelo homem, resultantes de conexões sinestésicas que mediatizam o seu reconhecimento e a diferenciação de seus enunciados.

Nesse sentido, indaga-se: como esse espaço-lugar latente das imagens e dos produtos culturais se articula com atributos e qualidades físicas dos produtos artísticos, de modo a permitir a produção de sentido a partir do contato humano?

A presente proposta de investigação pretende, por um lado, discutir a estética relacional e os novos ensaios de sociabilidade que se anunciam no sistema das artes hoje e, por outro, sua recepção na comunidade educacional, como vetor para outras experiências formativas.

A análise da incorporação da estética relacional às práticas e metodologias educacionais, no ensino da arte vigente, poderá contribuir para delinear estratégias educacionais que problematizem as matrizes teórico-metodológicas modernistas, as quais se apresentam como instrumento desatualizado, em virtude das constantes transformações da produção artística e, de igual modo, de seu ensino, que, na atualidade, requer um diálogo próximo com 
os fenômenos sociais que guardam e até mesmo exigem representatividade e participação total do educando.

O interesse em problematizar a arte na/da atualidade se justifica em razão de abordagens educacionais contemporâneas que a contextualizem e aproximem seus conteúdos do cotidiano dos educandos. É relevante priorizar o tempo histórico-social a que o educando pertence, convive e constrói, como estrutura essencial para o entendimento e reflexão desse mesmo momento em que o significado das coisas do mundo e da sociedade passa a ser o mediador da própria história do educando.

Hernández considera a arte como uma forma construtiva, utilizada "para que os indivíduos fixem as representações sobre si mesmo e sobre o mundo e sobre seus modos de pensar [a si mesmo]" (Hernández, 2000, p. 52), por meio de textos visuais que guardem significados procedentes dos espaços-lugares vivenciados pelo próprio educando, agente reflexivo-criador do seu tempo.

Todavia, é necessário problematizar as formas de produção e apresentação da arte contemporânea para um público que, não raro, a rejeita e a desconhece por não compreender seus conteúdos - o que, como bem sabemos, intensifica o seu distanciamento. $\mathrm{O}$ próprio sistema das artes, que avaliza essas produções e mantém preceitos de juízo e de valor, muito frequentemente equipara e não as diferencia do período que as antecedeu, o moderno.

O objeto de estudo desta proposta investigativa apresenta-se, portanto, como de fundamental importância para o ensino da arte, visto que: a) as pesquisas educativas acompanham as transformações contextuais e seus agentes; b) não sistematiza as mesmas transformações e agentes, ocultando ou desconsiderando a postura questionadora do pesquisador no campo do ensino da arte sob uma perspectiva linear ou descontextualizada; c) pode ampliar o cabedal reflexivo do ensino da arte para a capacitação de educadores, que viriam a suprir esta lacuna.

O enfoque se dará sobre os conteúdos de suas poéticas que partam das coletividades e da interação humana e, consequentemente, sobre análises de algumas formas discursivas que poderiam dinamizar e aproximar as metodologias de ensino e estratégias educacionais que visam englobar a aprendizagem de arte contemporânea.

Entendemos que os fenômenos artísticos se apresentam como estruturas socioculturais dinâmicas que requerem leituras sobre seus enunciados que visem estabelecer relações que rompam a superficialidade de um procedimento analítico tradicional e vislumbrem outras direções que sejam suficientemente 
significativas para atingir atitudes, condutas e percepções humanas que se entrecruzem entre o não dito e o pronunciado, objetivando conhecer a significação dos seus enunciados num sistema de entendimento "subjetivo-metafórico", por assim dizer.

O mote conceitual engendrado partirá de uma inspiração na análise discursiva de Michel Foucault (2008), por meio da qual serão observados alguns conceitos essenciais, tais como "discurso e suas unidades", "formação discursiva”, "enunciado", entre outros. Esses conceitos auxiliarão, inicialmente, a enxergar a materialidade a ser pesquisada e estabelecer conexões com os outros autores que discutem os dispositivos de arte, seus enunciados e operações que destaquem e qualifiquem a arte pós-1960.

Suas abordagens teóricas poderão constituir um conjunto de categorias que possibilitarão estabelecer leituras advindas de um contex to histórico-social no qual os dispositivos de arte são pensados, teorizados e, por conseguinte, compreendidos e ensinados.

A proposta de se aproximar dos conceitos prescritos pelo filósofo francês faz-se essencial quando reiteramos que, para dialogarmos como os discursos que legitimaram a arte durante o período moderno e seus enunciados balizadores, hoje em dia, não correspondem ou se aproximam aos conteúdos e às formas de tratamento que procuram explicar os diferentes enfoques e estruturas conceituais que despontaram com a arte produzida pós-1960.

É importante ressaltar que a análise sobre os discursos em torno da arte contemporânea poderá construir estratégias de ensino sobre a arte vigente. Para tanto, consideraremos que esses mesmos discursos, quando originários do campo das artes visuais, poderão adquirir outras formas de expressão e comunicação, que se distanciam da Linguística, como é o caso do uso das imagens como texto ou como dispositivo de textualidades visuais.

Nessa direção, inseriremos a análise de conteúdo como uma ferramenta metodológica que visa ler e interpretar o conteúdo de toda classe de documentos ou arquivos que se inscrevem dentro dos fenômenos da vida social como forma de comunicação, seja ela verbal ou não verbal. Severino (2007, p. 121) afirma:

É uma metodologia de tratamento e análise de informações constantes de um documento, sob forma de discursos pronunciados em diferentes linguagens: escritos, orais, imagens, gestos. Um conjunto de técnicas 
de análise das comunicações. Trata-se de se compreender criticamente o sentido manifesto ou oculto nas comunicaçóes. Envolve, portanto, a análise do conteúdo das mensagens, os enunciados dos discursos, a busca do significado das mensagens. As linguagens, a expressão verbal, os enunciados, são vistos como indicadores significativos, indispensáveis para a compreensão dos problemas ligados às práticas humanas e a seus componentes psicossociais. As mensagens podem ser verbais (orais ou escritas), gestuais, figurativas, documentais.

Análise de conteúdo, quando associada aos arquivos, na modalidade discursiva foucaultiana, constitui uma estratégia na condução do trabalho de pesquisa que seja capaz de analisar e trazer a descoberto uma série de informações sobre um determinado assunto, que não sistematiza ou quantifica dados, mas os interpreta a partir de correspondências, entrecruzamentos, distinções, aproximações e fricções correspondentes às estruturas semânticas, linguísticas, psicológicas ou sociológicas.

Bardin (2016, p. 49) faz o uso de analogias para distinguir os objetivos da análise de conteúdo (fala) da Linguística (língua); enquanto a Linguística se preocupa "com a descrição das regras de funcionamento da língua; a análise de conteúdo trabalha a fala, a prática da língua realizada por emissores identificáveis". A autora lança mão de uma metáfora do jogo de xadrez para descrever e diferenciar cada uma delas: ressalta que a Linguística não procura saber o que significa uma partida, porém descreve as regras que tornam possível o jogo; já a análise de conteúdo visa compreender os jogadores e o ambiente em que se inserem, pontua as significações, ou seja, o conteúdo que faz com que cada um deles tenha determinadas atitudes e que os auxilie a nas decisões sobre as estratégias no jogo.

A autora diz que o objetivo da análise de conteúdo consiste em:

Um conjunto de técnicas de análise das comunicações visando obter por procedimentos sistemáticos e objetivos de descrição do conteúdo das mensagens indicadores [...] que permitam a inferência de conhecimentos relativos às condições de produção/percepção (variáveis inferidas) dessas mensagens (Bardin, 2016, p. 48).

A inserção de Bardin servirá para entender o objeto de estudo, estabelecer relações sobre as ideias propostas pelos autores que auxiliem a analisar 
os índices sobre os conteúdos que determinam leituras em torno da arte do presente e seu ensino.

\section{Estado de trocas e convivência: as relações humanas na arte do presente e seu ensino}

Os dispositivos da arte do presente experimentam as relações humanas como manifestações sociais que possibilitam, de certo modo, um estado de trocas entre a vida real e o mundo da arte.

O que se percebe em algumas exposições de arte são ensaios de sociabilidade, como um dos principais objetos de pesquisa utilizados pelos artistas, sejam eles oficiais, periféricos, virtuais ou mesmo aqueles que possibilitem conexões articuladas com textos visuais e/ou conceituais, aparentemente triviais ou desconexos.

Para esse tipo de propostas de arte, são de interesse de alguns artistas elementos oriundos de um ou de vários universos sociais, que podem designar poéticas, nas quais são estabelecidas práticas de convívio que possuem os mais variados escopos, suportes e formatos. Nessa direção, percebe-se que os projetos culturais dirigidos por artistas incorporam e transitam nesse universo de coletividades, criando classes de correspondência da realidade social com suas intenções de dimensão estéticas.

Bourriaud (2009) elabora um glossário que direciona o leitor para palavras-chave que sustentam a sua tese; a primeira delas é arte relacional, compreendida por ele como o "conjunto de práticas artísticas que tomam como ponto de partida teórico e prático o grupo das relações humanas e seu contexto social, em vez de um espaço autônomo e privado" (Bourriaud, 2009, p. 151); já estética relacional designa, para o mesmo autor, "a teoria que consiste em julgar as obras de arte em função das relações inter-humanas que elas figuram, produzem ou criam"(p. 151); a arte, por sua vez, é concebida por Bourriaud como sendo "uma atividade que consiste em produzir relações com o mundo com o auxílio de signos, formas, gestos ou objetos” (p. 147). Como centro da produção artística, na abordagem adotada pelo referido autor, as contribuições e as ações humanas são essenciais para a produção de sentido junto às obras de arte.

O uso da estética do cotidiano e a interação humana partem da premissa do coeficiente de arte duchampniano, pois, segundo Battcock (2002, pp. 73-4), 
não existe arte que desconsidere o espectador e que, além do mais, não o coloque no centro de todo processo de formação de sentido. A arte não está "fora" do espectador, pois é dele e da desconstrução de seus preconceitos e adjetivos sobre aproximações de cultura da arte que derivam outras possibilidades de leituras relacionais do meio que a gerou; ele consiste naquilo que Battcock (2002) designou como o "estranho-familiar".

A Estética Relacional procura, com efeito, atenuar esse hiato - a participação do espectador como gerador de outros enunciados a partir dos dispositivos artísticos.

As manifestações artísticas contemporâneas, balizadas por princípios de ordem relacional, interativa, constituem espaços-tempo de troca, ou, dito de outro modo, interstícios sociais. Sendo assim, elas podem se dar tanto pela criação de "coletividades instantâneas", como por meio de "intervenções urbanas”, que transformam as relações de convívio em uma condição legítima de arte (Bourriaud, 2009).

Como se pode observar, existe nessas formas artísticas uma integração social acentuada, cujas intenções não distinguem ou apartam o público da sociedade e de suas experimentações; ao contrário, é fundamental que se tenha a participação dele, seja da forma que for, para que a proposta artística atinja seus objetivos.

Jacques Rancière (2005, pp. 18-9) pondera, a esse respeito, que a construção de sentido conceitual-formal parte, não raro, de simultaneidades sociais, uma vez que

a superfície dos signos 'pintados', o desdobramento do teatro, o ritmo do coro dançante [constituem] três formas de partilha do sensível, estruturando a maneira pela qual as artes podem ser percebidas e pensadas como artes e como formas de inscrição do sentido da comunidade. Essas formas definem a maneira como obras ou performances 'fazem política', quaisquer que sejam as intenções que as regem, os tipos de inserção social dos artistas ou o modo como as formas artísticas refletem estruturas ou movimentos sociais.

Os espaços de convívio dinamizam possibilidades reais ou virtuais para diminuir a noção de espaço privado, restrito e distinto, possuindo diferentes graus de sociabilidade. Para Bourriaud (2009, pp. 27-8), houve, por certo, um enriquecimento dos conteúdos e experimentações artísticas no século $\mathrm{XX}$, 
com uma série de informações visuais e dispositivos formais que estabeleceram conjunções da arte com o público até então inexistentes.

Com essa abordagem de estética relacional, do cotidiano, foi possível alargar os espaços-lugar para o trânsito da arte. Se, anteriormente, a arte estava restrita aos museus, galerias e fundações, hoje ela se dá - e tenciona incorporar - na cidade, na natureza e no espaço virtual -, tendo como finalidade aproximar-se cada vez mais do conjunto formado pelos artistas, suas poéticas e o público, seja ele iniciado ou não. Compreende-se, portanto, que é no outro que a arte se completa, cuja ambivalência consiste precisamente em integrar o seu princípio ativo - o homem - como foco central de suas discussões.

Anne Cauquelin (2005) aponta para a ideia - construída em torno da arte - que se tornou como um obstáculo para o reconhecimento por parte do público da arte de agora. De acordo com ela, "é provável que estejamos saturados de certas ideias recebidas que [supúnhamos] universais e duradouras, esquecendo as diferentes formas e os diferentes status aos quais a obra e o artista estiveram submetidos nos diferentes períodos da história” (p. 17).

Isso posto, cabe-nos perguntar: esse momento de transformação da arte está sendo abordado nas práticas de ensino da arte na atualidade? Que instrumentos ou metodologias a englobam? O ensino da arte, na atualidade, está discutindo e incorporando esse movimento sociocultural que se apresenta como uma outra tendência?

Observa-se que a educação é formada pelo mundo, pela sociedade e pelos movimentos culturais que a dinamizam, estes entendidos como as mais diversas formas de interpretação e de possibilidades de mediação e de significação, da reconstrução e do reconhecimento do próprio contexto que a gerou.

Ao se referir à arte moderna como um obstáculo, a autora reforça, em suas intenções, que a linearidade discursiva moderna, ainda presente nos dias atuais, tende a inserir suas diretrizes de análise em outras tipologias de arte, cujos conceitos, materialidade e destino não se enquadram ou transitam dentro dos limites estabelecidos e reconhecíveis pelo discurso modernista.

Barbosa (2005) afirma que o ensino da arte no Brasil transcreveu as ideias de John Dewey, as quais se pautavam pela observação e integração da experiência acumulada e a formação processual do indivíduo como fundamento basilar; todavia, o ensino da arte modernista brasileira primava, unicamente, pelo estágio final do processo cognitivo. A arte era, com efeito, usada como reforço para os educandos fixarem conteúdos de outras disciplinas. Nessa direção, para compreender determinado assunto, eram trabalhadas atividades 
manuais e práticas de desenho de observação como etapas que encerravam o entendimento do assunto abordado.

Depois da Semana de Arte Moderna de 1922, o ensino da arte no Brasil passou a seguir a prática de copiar modelos, por meio do desenho de observação, e insere, de forma mais abrangente, o conhecimento de técnicas manuais, com, objetivo de treinar habilidades. Na escola tradicional, as habilidades manuais eram supervalorizadas, o domínio técnico visava à formação prática destinada à qualificação para o mercado de trabalho. $\mathrm{O}$ ensino da arte tinha aspecto utilitário e visava à "preparação do estudante para a vida profissional e para as atividades que desenvolviam, tanto em fábricas quanto em serviços artesanais" (Ferraz e Fusari, 1992, p. 30). Essa metodologia de ensino se estende até os anos 1960.

Os anos 1960 representam, no âmbito da arte, uma retomada às provocações que Marcel Duchamp havia enunciado no princípio do século, exigindo a participação do espectador para o centro das propostas artísticas. No que tange às práticas educacionais da arte, depois da Ditadura Militar no Brasil, a educação artística, que compreendia artes plásticas, música e artes cênicas, passou a fazer parte dos currículos escolares.

No ano de 1987, como metodologia de ensino da arte, Ana Mae Barbosa cria a Proposta triangular, composta de leituras de obras de arte, do fazer e do contextualizar. Vale ressaltar que essas tentativas dinamizaram o ensino da arte no Brasil, ainda que desconsiderassem as expressões artísticas hoje correntes, tais como a estética do cotidiano e as relações inter-humanas.

A Cultura Visual, por sua vez, surge nos anos 1990 como posicionamento político que buscava incorporar, estudar e compreender outras imagens que se distanciavam das tradicionais, como, por exemplo, o grafite, as imagens digitais, as imagens produzidas pela televisão e pelo cinema. Barbosa (2005, p. 16) destaca que a expressão "cultura visual" passou a ser incorporada no ensino da arte brasileira com um curso realizado por Kerry Freedman, em São Paulo, e com a publicação do livro Cultura visual, mudança educativa e projeto de trabalho (2000), de Fernando Hernández. Para a cultura visual, o cerne do ensino e da aproximação dos bens e produtos culturais tem como primazia, segundo Hernández (2000, p. 51),

[r] econhecer que vivemos inundados de uma extraordinária variedade de imagens (e imaginários) visuais. Mas esse reconhecimento não nos 
leva a lê-los, a partir de uma composição analítico-compositiva do tipo formal (linhas, texturas, etc.). Aproximar-se dos objetos visuais significa, como nos indica Jay (1996), colocar num segundo plano a crença que o valor de que o valor estético depende de uma resposta universal, e que essa resposta é representada pelos membros mais 'qualificados' da comunidade. Prestar atenção à compreensão da cultura visual implica aproximar-se de todas as imagens (sem limites demarcados pelos critérios de um gosto mais ou menos oficializado) e estudar a capacidade de todas as culturas para produzi-las no passado e no presente com a finalidade de conhecer seus significados e como afetam nossas 'visões' sobre nós mesmos e sobre o universo visual em que estamos imersos.

Estabelecer aproximações com a cultura visual e a estética relacional possibilita transitar sobre as ações humanas, seus hábitos e costumes inscritos não somente sobre as imagens produzidas na atualidade, mas também sobre os atributos valorativos de identificação sociocultural emergentes.

Tal concepção dialoga, por certo, com a estética relacional. Em seu livro Pós-produção: como a arte reprograma o mundo contemporâneo, Nicolas Bourriaud $(2009$, p. 8) afirma que a

arte da pós-produção corresponde tanto a uma multiplicação da oferta cultural quanto - de forma mais indireta - à anexação ao mundo da arte de formas até então ignoradas ou desprezadas. Pode-se dizer que esses artistas que inserem seu trabalho no dos outros contribuem para abolir a distinção tradicional entre produção e consumo, criação e cópia, ready-made e obra original. Já não lidam com uma matéria-prima. Para eles, não se trata de elaborar uma forma a partir de um material bruto, e sim de trabalhar com objetos atuais em circulação no mercado cultural, isto é, que já possuem uma forma dada por outrem.

A contiguidade da estética relacional com a cultura visual assinala possibilidades de aproximação para a construção de um debate significativo e exponencial para o ensino da arte no período atual, pois ambas trazem para o centro da discussão as transformações existentes na sociedade contemporânea, as relações inter-humanas e a experiência com as novas mídias, as quais permitem esboçar outras direções e práticas educacionais no que se refere às tipologias dos produtos culturais e ao ensino da arte vigentes. 
A arte do presente não delimita fronteiras temporais e tampouco possui a ideia de negação do passado para instituir-se como outro sistema de experimentações poéticas ou conceituais; pelo contrário, ela visa estabelecer diálogos com o passado, com o presente, que a fortalecem e a destacam e, também, com possíveis indicações sobre possibilidades de tendências do devir artístico.

Nas proposições artísticas vigentes, observa-se que um dos principais instrumentos de análise e projeção da arte é o discurso. Via de regra, são esses novos discursos sobre as proposições artísticas que surgem, como é o caso da estética relacional, que anunciam uma grande mudança em relação ao que se convenciona chamar de arte. Sua principal diretriz é estabelecer juízo de análise sobre os dispositivos que se centralizam sobre as ações humanas coletivas.

Por ser experimental, a arte de agora possibilita diálogos com toda cadeia de signos que guardem em si potencialidades de gerarem sentidos com o presente, sem regras de temporalidade, espacialidade ou origem, como elementos valorativos que quando justapostos indiquem a construção de significados atualizados.

Se a principal preocupação dos artistas modernos incidia sobre a atualização dos temas da arte, no momento atual observa-se a tentativa de construir outros conceitos sobre arte a partir do apelo filosófico. Nessa direção, há um deslocamento do objeto de arte que intermedeia a construção de sentido para o espectador que se transforma em dispositivo e passa a ser o próprio "objeto" de arte, na construção de um processo experimental que tensiona as barreiras da forma e se constitui sobre as experiências humanas conjuntas de relações com o mundo.

A década de 1990 foi marcada pelo início da popularização dos meios eletroeletrônicos, que fascinavam uma parcela da população com acesso às redes de comunicação e, nesse sentido, já apontavam para um fenômeno de individualização que se tornaria mais forte nas décadas subsequentes.

De imediato, o fascínio pela busca da informação instantânea e a possibilidade de encurtar distâncias territoriais fez com que uma parcela considerável da população constituísse um fenômeno sociocultural emergente de retração convivial, que os transformaria em membros isolados e solitários, cujos percursos de proximidade com o outro estariam fadados única e exclusivamente ao contato virtual. 
A estética relacional surge como uma outra abordagem e propõe uma prática discursiva sobre arte naquele momento em que os indivíduos se tornavam cada vez mais isolados do contato com seus pares.

O discurso da tese proposta por Nicolas Bourriaud considera as ações coletivas como fator determinante para reconfigurar a reflexão sobre os produtos emergentes de arte, cujos enunciados se centrariam no público com sua participação efetiva e na figura do artista, como mediador de possibilidades de momentos de convívio entre as pessoas que realizariam tais ações conjuntas. Vale lembrar que a estética relacional é uma teoria estética que se fundamenta sobre uma reflexão formal, ou seja, é uma teoria que parte das formas artísticas que despontaram na arte a partir do anos 1990, tendo as coletividades e os estados de trocas humanos como forma distinta, emergente e ocasional.

Alguns dos principais vetores de investigação da estética relacional proposta por Nicolas Bourriaud são: a) fatores humanos de toda ordem; b) a sociedade em processo constante de transformação; c) o homem e suas histórias de vida e identidade; d) sua cultura e singularidades.

A estética relacional se apresentaria, portanto, como outro percurso de pesquisa das relações humanas na contemporaneidade, o qual se dirigiria na contramão dos meios de comunicação de rede e das seduções virtuais próprias do momento presente.

As tipologias apresentadas por Bourriaud (2009, pp. 40-56) se constituem em cinco grandes categorias: as conexões e pontos de encontro; convivio e encontros casuais; colaborações e contratos; relações profissionais; clientelas e como ocupar uma galeria. Para cada uma dessas categorias artísticas, o autor relacionou artistas de diferentes momentos da arte e exemplificou com suas produções como a estética relacional as identificou e as analisou enquanto experimentos de práticas sociais.

O ensino da arte, quando se ocupa em problematizar uma visão fenomenológica do mundo - da sociedade e das manifestações artísticas que reverberam conteúdos atuais, associadas a dinâmicas educacionais -, viria a suprir as crescentes mudanças que o educando apresenta, a partir, evidentemente, do seu entendimento da sociedade e do contexto em que vive, tal como sublinha Efland (2005, p. 117): 
[...] uma arte-educação pós-modernista enfatiza a habilidade de interpretar obras de arte sob o aspecto de seu contexto social e cultural como principal resultado da instrução. Isso é válido não apenas para a supostamente séria, a arte erudita, mas também para as tendências e impactos da cultura popular e cotidiana.

Esta reflexão sobre o ensino da arte para o período atual pretendeu, outrossim, identificar, articular e problematizar diversos fatores que integram os processos de produção de conhecimento no campo do ensino da arte - em particular, da arte contemporânea, no Brasil -, de forma a auxiliar na reflexão e aprimoramento das práticas pedagógicas dos professores de arte no contexto escolar.

Nessa direção, procuramos estabelecer aproximações com os dispositivos emergentes da arte de agora, com seus conteúdos que transitam sobre um processo ininterrupto de mudança social, sua volumosa inclusão nas propostas artísticas e a estética relacional, cujo principal argumento repercute sobre as relações inter-humanas e focaliza o seu juízo de valor sobre a arte vigente, a partir da inserção da figura do homem contemporâneo como formador de outra postura relacional com as proposições artísticas e a sua recepção.

Ao se referir à recepção da arte contemporânea e de possíveis relações com os enunciados propostos pela estética relacional, este texto verificou em que medida o ensino que aborda a arte contemporânea se aproxima ou se orienta por alguns vetores elucidados por Nicolas Bourriaud, em sua tese sobre as relações humanas, presentes no mundo da arte de agora.

A arte contemporânea - como sendo orientação artística plural do tempo presente, inscrita pela sociedade como atividade humana capaz de criar e propor dispositivos que englobem as coisas de um mundo globalizado, multicultural e tecnológico - transita entre as mais variadas linguagens e desafia o sistema estabelecido, as representações e a validação da própria arte; nela, é incluída - e ao mesmo dela se distingue - a estética relacional, como juízo de valor que parte das relações humanas e propõe criar conjuntos-cognitivos-coletivos que engendram outra forma de proximidade com os dispositivos que hoje se anunciam na arte; se associadas, implicam a observação de indícios que reverberam sobre as ações humanas e suas coletividades, num sistema distinto e eventual, cujos limites de formulação, enunciação e recepção condensam os relacionamentos humanos, os equipamentos culturais e a tecnologia como outra marca da sociedade humana inscrita nas poéticas do presente. 


\section{Referências}

AGAMBEN, Giorgio. O que é contemporâneo? E outros ensaios. Chapecó: Argos, 2009.

AUMONT, Jacques. A imagem. Campinas: Papirus, 1993.

BARBOSA, Ana Mae. Tópicos utópicos. Belo Horizonte: C/Arte, 1998.

(org.). Arteleducação contemporânea: consonâncias internacionais. São Paulo: Cortez, 2005.

BARDIN, Laurence. Análise de conteúdo. São Paulo: Edições 70, 2016.

BATTCOCK, Gregory (org.). "O ato criador". In DUCHAMP, Marcel. A Arte Nova. São Paulo: Perspectiva, 2002.

BOURRIAUD, Nicolas. Estética relacional. São Paulo: Martins, 2009.

. Pós-produção: como a arte reprograma o mundo contemporâneo. São Paulo: Martins, 2009.

CAUQUELIN, Anne. Arte contemporânea: uma introdução. São Paulo: Martins, 2005.

. Teorias da arte. São Paulo: Martins, 2005.

EFLAND, Arthur D. "Cultura, sociedade, arte e educação num mundo pós-moderno”. In GUINSBURG, J. e BARBOSA, Ana M. O pós-modernismo. São Paulo: Perspectiva, 2005.

FOUCAULT, Michel. A arqueologia do saber. Rio de Janeiro: Forense Universitária, 2008.

FUSARI, Maria Felisminda de Rezende e FERRAZ, Maria Heloísa Corrêa de Toledo. Arte na educação escolar. São Paulo: Cortez, 1992.

HERNÁNDEZ, Fernando. Cultura visual, mudança educativa e projeto de trabalho. Porto Alegre: Artes Médicas, 2000.

RANCIÈRE, Jacques. A partilha do sensivel. São Paulo: EXO experimental; Editora. 34, 2005.

SEVERINO, Antonio Joaquim. Metodologia do trabalho cientifico. São Paulo: Cortez, 2007. 


\section{Formação de professores de geografia}

\section{Trajetórias e desafios do Programa Institucional de Bolsa de Iniciação à Docência (PIBID)}

Gilda Maria Cabral Benaduce Lisane Regina Vidal Conceição

\section{Introdução}

O presente capítulo aborda o ensino e a formação de professores de Geografia, tendo como foco discussões que versam sobre as atividades docentes desenvolvidas por meio de um subprojeto da Geografia vinculado ao Programa Institucional de Bolsa de Iniciação à Docência (PIBID). Tais atividades são o fruto das reflexões compartilhadas entre os participantes do programa, professora coordenadora, professoras supervisoras e alunos bolsistas do curso de Geografia, ao longo da vigência do programa na Universidade Federal de Santa Maria (UFSM).

Nesse contexto, o presente artigo discute as concepções de conhecimento escolar e os desafios do programa para com a Geografia na escola, bem como as trajetórias traçadas pelos antigos bolsistas do programa. O desenvolvimento do trabalho deu-se mediante o estudo das atividades desenvolvidas nas escolas públicas e desafios contemporâneos enfrentados pelos antigos bolsistas em seu trabalho diário como docentes na escola. Para tal, foram aplicados questionários com antigos bolsistas de iniciação à docência do programa.

Compreende-se que, para muitas escolas públicas de ensino fundamental e médio, ainda é um desafio reconhecer e trabalhar com conhecimentos que sejam significativos para os educandos, cuja concepção do conhecimento tem oscilado entre perspectivas ainda conservadoras e perspectivas 
emancipatórias e críticas. Dessa forma, junto à escola, o PIBID busca desenvolver atividades que promovam aprendizagens significativas aos alunos por meio de práticas que, ao mesmo tempo, possibilitem novos aprendizados aos acadêmicos em formação, contribuindo para a formação docente, pois, conforme ressalta Callai (2013), o professor vai saber ensinar se ele aprendeu.

Portanto, acredita-se que a prática pedagógica proporcionada pelo PIBID seja fundamental para a formação de professores conhecedores da Geografia escolar.

\section{Iniciação à docência e seus saberes}

A formação de professores encontra no PIBID a possibilidade de vivenciar o diálogo entre a formação teórica oportunizada na universidade com aquela oportunizada pela escola, compondo, antes de tudo, uma postura de troca e não de sobreposição de saberes. A partir desse ponto de vista, entende-se que a escola e seus professores possuem experiências e saberes importantes a serem compartilhados com a universidade, que, por conseguinte, tem a necessidade de compartilhar suas pesquisas com a escola.

Nessa direção, o PIBID Geografia, em desenvolvimento na universidade, objetiva compreender as mudanças educacionais, que interferem no ensino de Geografia. Tais mudanças devem estar relacionadas às complexas transformações sociais que nem sempre são paralelas às mudanças educacionais, configurando um descompasso que acentua a necessidade de avaliar e monitorar essas situações. A investigação também é outro aspecto relevante, especialmente nas ações que retratam características da geografia tradicional escolar, para que esta possa ser superada e estendida ao cotidiano do educando.

É também relevante contribuir para o entendimento do mundo atual, que se dá pela apropriação do espaço pelos homens, da apropriação da natureza pelo homem e da organização do mundo, no que tange aos arranjos culturais, sociais e econômicos construídos historicamente. Pautada na realidade contemporânea, a Geografia é a ciência do presente, e seu estudo recai no espaço geográfico construído pelo homem e cuja visibilidade nunca foi tão explorada como nos dias atuais. 
A Geografia no ensino básico pressupõe ao educando a inserção das noções espaciais, em suas diversas escalas e configurações, oportunizando-lhe situações para lidar com as categorias espaço, natureza, paisagem, conexões com o mundo atual e com a sua realidade. É também relevante propiciar condições para a construção de competências, revelando o real, estabelecendo patamares em relação ao contexto espacial dos fenômenos que configuram cada sociedade com a própria realidade. Identificar o seu lugar no mundo permite que o educando seja mais problematizador que explicativo; sobre o espaço cotidiano, que ele seja mais crítico do que passivo; e, ao estabelecer comparações, contradições e desafios, que seja feito em nível local e global.

Nesse sentido, o projeto político-pedagógico do curso de Licenciatura em Geografia da UFSM pontua a formação acadêmica, cujos contornos asseguram leituras da realidade, por meio de elementos norteadores da organização curricular, na definição das competências e habilidades básicas a serem desenvolvidas no ensino, a partir dos referenciais propostos pelo conhecimento científico da Geografia.

No projeto PIBID/Geografia, tanto na edição de 2011 como em 2014, envolveram-se dez bolsistas, acadêmicos do curso de Licenciatura em Geografia, duas professoras de escola pública (supervisoras na escola), duas escolas públicas e um professor da Universidade (coordenador de área). O desenvolvimento do programa ocorre em duas escolas públicas de educação básica da cidade de Santa Maria, Escola Estadual de Ensino Médio Dom Antônio Reis e Instituto Estadual Luiz Guilherme do Prado Veppo, atendendo tanto ao Ensino Fundamental como ao Ensino Médio, respectivamente, ambas pertencentes ao estado do Rio Grande do Sul.

As dinâmicas propostas nesse projeto permitem que todos os bolsistas de graduação participem do cotidiano da escola pública, desenvolvendo atividades ligadas ao ensino/aprendizagem, elaborando questóes de pesquisa de forma integrada às demandas da escola. Na universidade, por sua vez, apresentam essas questões para discussão e debate em reuniões semanais.

Durante o acompanhamento do trabalho, a docência estrutura-se também como um campo de pesquisa, no sentido das possibilidades e dos desafios do cotidiano escolar, no qual é possível exercitar os princípios de uma educação libertadora, tomando-se, como ponto de partida para o trabalho, o diálogo entre estudantes e professores, entre os bolsistas do PIBID e seus coordenadores e supervisores, e entre os educandos da escola pública e os bolsistas do PIBID. 
As atividades em sala de aula envolvem desde a busca pelo conteúdo programático desenvolvido, assuntos de interesse dos educandos, até os temas e estudos a serem realizados pelos bolsistas. Essa seleção dá-se coletivamente, tendo como base teórico-metodológica aqueles educadores que priorizam mais o processo de aprendizagem do que propriamente o conteúdo. Freire (1972) exige uma nova educação expressa em uma nova escola, voltada à fomentação de perspectivas de mundo, de humanização e de aprendizagem que se tornem possíveis no momento atual, às quais o autor contrapõe as perspectivas escolares, por ele denominadas de educação bancária.

No subprojeto Geografia, tanto no Ensino Fundamental como no Ensino Médio, os bolsistas desempenham o mesmo tipo de ação: realizam as atividades nas aulas, participando delas, e, eventualmente, desenvolvem oficinas no contraturno, buscando colaborar com educando e professor. As oficinas e atividades são planejadas pela professora coordenadora do subprojeto e acompanhadas, na escola, pelas professoras supervisoras.

As dinâmicas demonstram ser possível observar que saberes e espaços de formação são articulados por demandas provocadas pelas práticas na escola, bem como emergem dos debates e de leituras realizadas. De todo, é necessário fornecer aos bolsistas espaço para perguntas, questionamentos e autonomia na organização, enfim, criar espaços de diálogo, em que se sintam participantes e integrantes de um processo de ensino/aprendizagem contínuo, permitindo a cada indivíduo compartilhar angústias e anseios, no intuito de possibilitar caminhos a serem trilhados na jornada de educar.

De modo geral, o PIBID/Geografia tem sido uma forma de experienciar novas maneiras de atuação no ambiente escolar, e de verificar sua relevância no avanço da aprendizagem dos educandos envolvidos e, ao mesmo tempo, aproximando a escola da universidade, fazendo com que os bolsistas vivenciem a prática escolar, tornando-os conhecedores de sua prática como professores e, ainda, possibilitando aos professores da educação básica uma continua atualização de saberes e vivências. 


\section{Teoria/Prática - 0 cotidiano}

Muito debatidas em disciplinas do curso de Licenciatura em Geografia, as novas formas de atuar no ambiente escolar foram inferidas mais fortemente quando discutidas novas linguagens no ensino de Geografia. Tais linguagens podem ser desenvolvidas e utilizadas tanto para atividades de reforço como para oficinas ou mesmo para atividades lúdicas. Esse processo requer um contexto articulado e ativo, que permita a igualdade de condições para todos os atores na superação das limitações e ambiguidades do ensino formal.

O que se nota é um grande distanciamento entre as aprendizagens provindas da universidade com as aprendizagens envolvidas na prática da docência na escola. Os dois espaços são diferentes. Todavia, na universidade, há uma intencionalidade de integração da formação, sem dicotomia entre teoria e prática, uma vez que ambas precisam ser refletidas por meio das aprendizagens da docência. Sendo assim, ambas seriam espaços de formação teórico/prática.

Nesse contexto, o trabalho dos bolsistas está pautado na valorização das práticas e trabalhos que já existem na escola, construindo uma integração com o espaço de formação acadêmica. Também desenvolvem a prática a partir da perspectiva dos educandos e dos professores como sujeitos de saberes construindo,, por conseguinte, construindo conhecimento necessário para a educação de século XXI.

A seguir, seguem algumas atividades desenvolvidas pelo PIBID junto às escolas e também atividades realizadas no Seminário Institucional do PIBID da UFSM.

A atividade envolveu educandos do $1 .^{\circ}$ ano do Ensino Médio, cujo objetivo era confeccionar mapas táteis para que eles pudessem reconhecer os continentes por meio da forma, corroborando para formarem mentalmente a imagem do mapa-múndi. Além disso, tinha por objetivo despertar nos educandos a importância da inclusão social, pois aqueles com necessidades especiais precisam de atividades diferenciadas das habituais para que aconteça o processo de ensino aprendizagem. Nesse caso, os mapas táteis funcionam como recursos educativos capazes de facilitar a compreensão da realidade. 
Figura 1: Atividade PIBID/Geografia/UFSM, em 2016. A, B, C e D - Confecção de mapas mundiais táteis com educandos do $1 .{ }^{\circ}$ ano do Ensino Médio
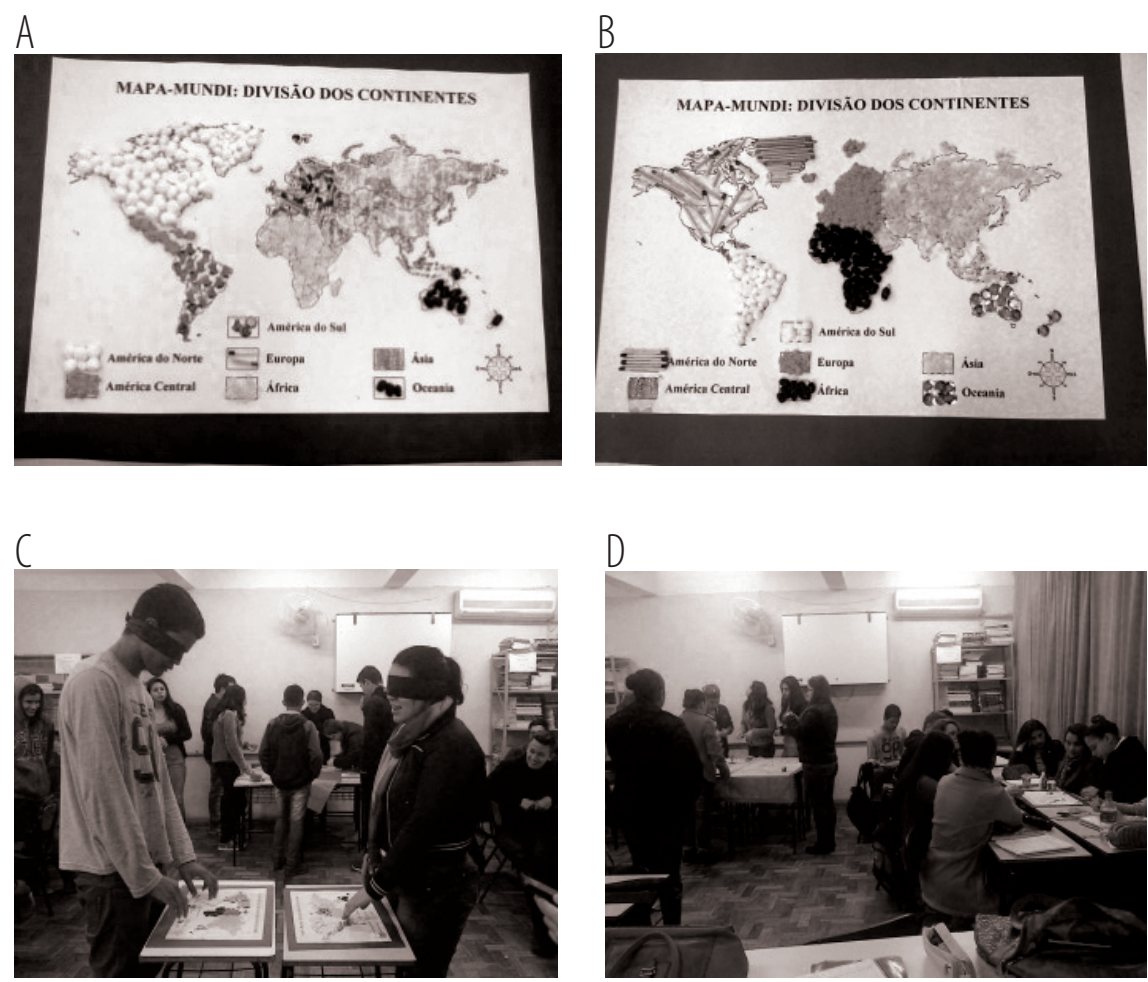

Fonte: arquivo do PIBID/Geografia/UFSM, em 2017.

De acordo com Loch (2008), o uso de mapas permite compreensão geográfica do mundo, facilita a mobilidade espacial e possibilita a ampliação da percepção espacial.

A confecção de maquetes sobre as placas tectônicas, realizada com educandos do $3 .^{\circ}$ ano do Ensino Médio, cujo objetivo foi trabalhar esse conhecimento de forma que os alunos pudessem compreender como o fenômeno acontece na natureza. Para tal, eles confeccionaram maquete, simulando movimento entre os limites divergentes e convergentes das placas tectônicas.

A figura 2 demonstra uma maquete $\mathrm{A}$ e $\mathrm{B}$ das placas tectônicas com alunos do $3 .^{\circ}$ ano do Ensino Médio em 2014; C e D - maquete da cidade de Rio Grande (RS), realizada pelos alunos de $10^{\circ}, 2 .^{\circ}$ e $3 .^{\circ}$ anos do Ensino Médio, em 2014. 
Figura 2: Atividades do PIBID/Geografia/UFSM, em 2014
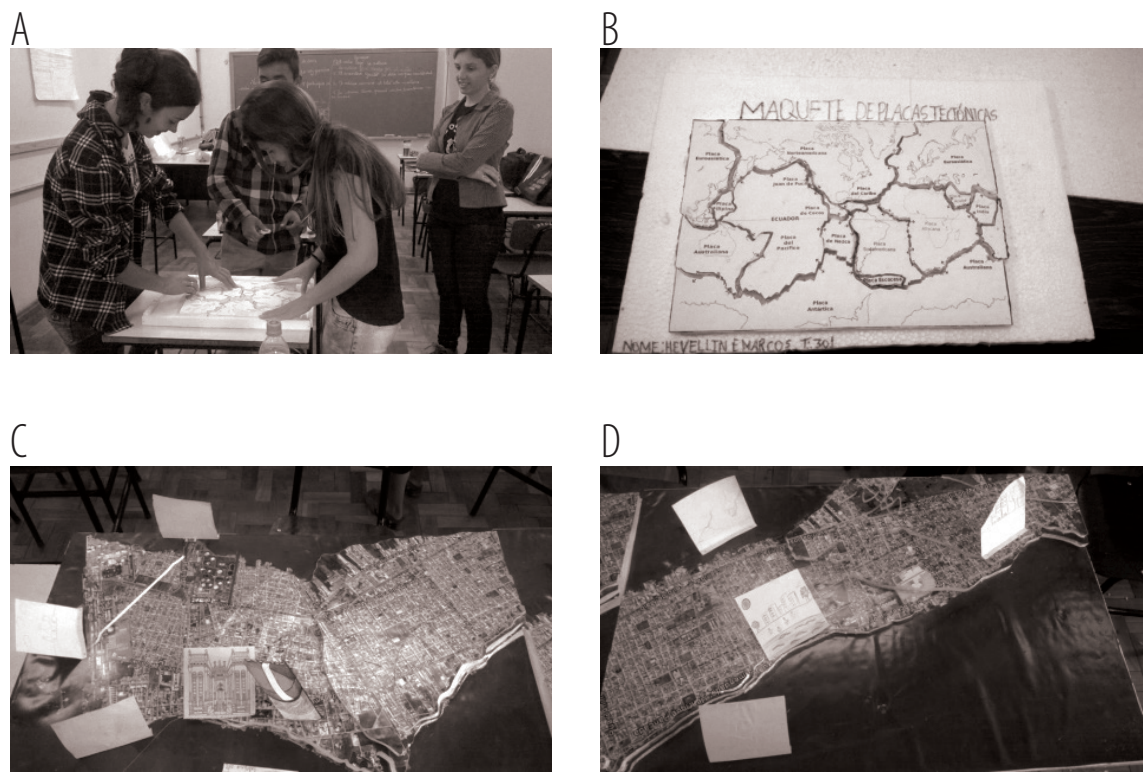

Fonte: Arquivo do PIBID/Geografia/UFSM, em 2017.

A maquete da cidade de Rio Grande (RS) foi confeccionada pelos educandos do Ensino Médio, objetivando a construção de conhecimentos sobre os aspectos físicos, históricos, econômicos da cidade. Esse foi o tema gerador de projetos em todas as áreas de conhecimento, e coube à Geografia representar, cartograficamente, a noção de lugar, uma vez que as diversas linguagens utilizadas para aprendizagem, como a maquete, se tornam fundamentais ao ensino da Geografia por trabalharem tanto a compreensão do espaço geográfico como a realidade vivenciada pelos educandos.

Nesse contexto, Almeida (2001) enfatiza ser o ensino de mapas e de outras formas de representação espacial uma importante tarefa da escola, ou seja, preparar o aluno para compreender a organização da sociedade, a que passa necessidade de conhecimento de técnicas e instrumentos à representação gráfica dessa organização.

A Fígura 3 demonstra, na imagem A, a oficina sobre o mosquito da dengue ministrada no Seminário Institucional do PIBID/UFSM, em 2016; na imagem $B$, a confecção da armadilha do mosquito da dengue e, na imagem C, a participação no Seminário Institucional do PIBID/UFSM, em 2016. 
Figura 3: Atividades do PIBID/Geografia/UFSM, em 2016
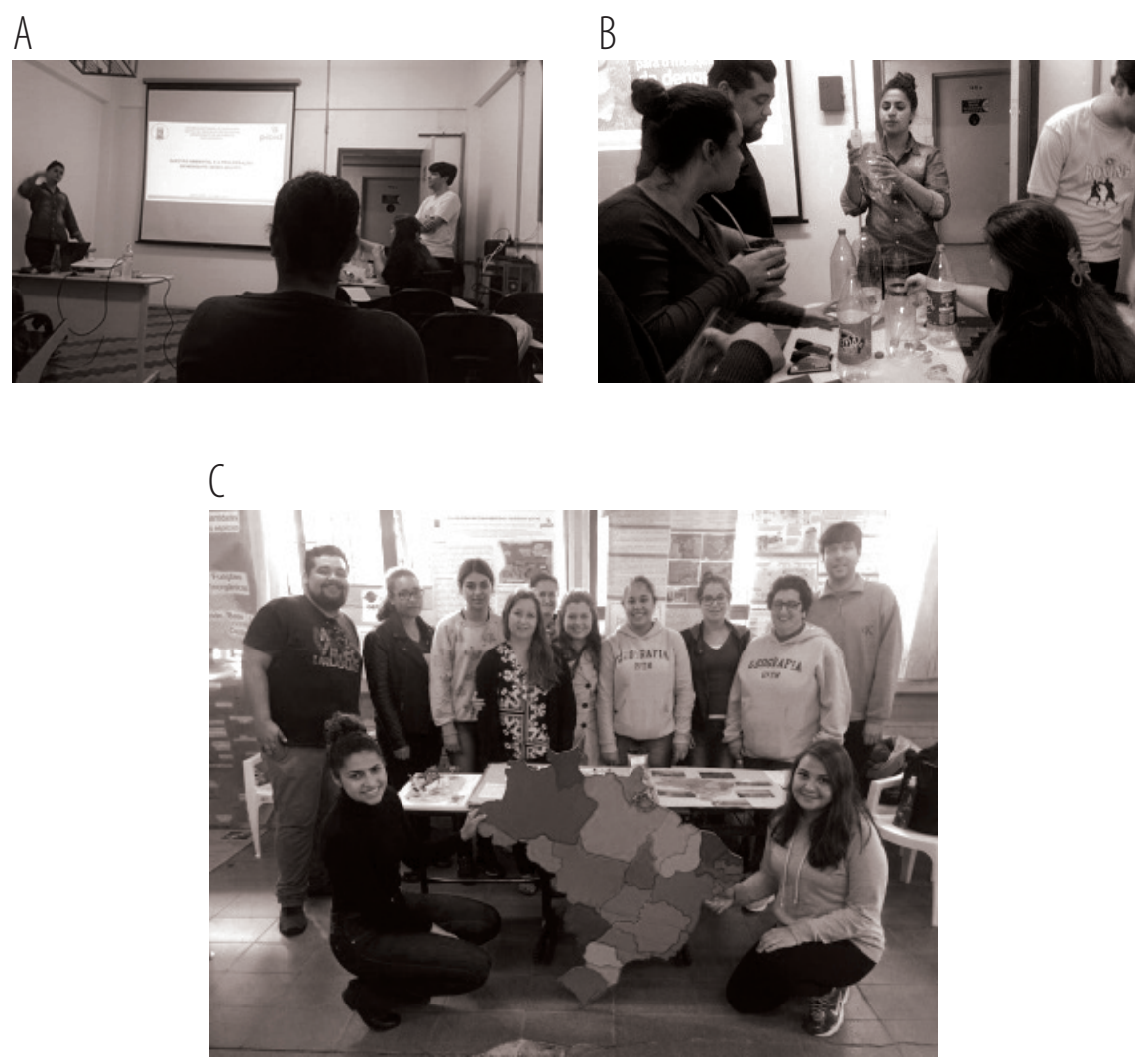

Fonte: Arquivo do PIBID/Geografia/UFSM, em 2017.

O Seminário Institucional do PIBID da Universidade Federal de Santa Maria acontece anualmente e tem por objetivo a troca de experiências e aprendizagens entre os subprojetos. É de responsabilidade de cada subprojeto oferecer uma oficina no seminário, cujo objetivo permite que bolsistas de outros subprojetos interajam com o referido tema e que tais oficinas deem visibilidade aos trabalhos desenvolvidos, como também promovam atividades conjuntas entre os subprojetos. A partir da figura $4-\mathrm{A}, \mathrm{B}, \mathrm{C}$ e D -, visualiza-se a confecção de cidades sustentáveis por educandos do $7 .^{\circ}$ ano do Ensino Fundamental, em 2017. 
Figura 4: Atividade do PIBID/Geografia/UFSM, em 2017
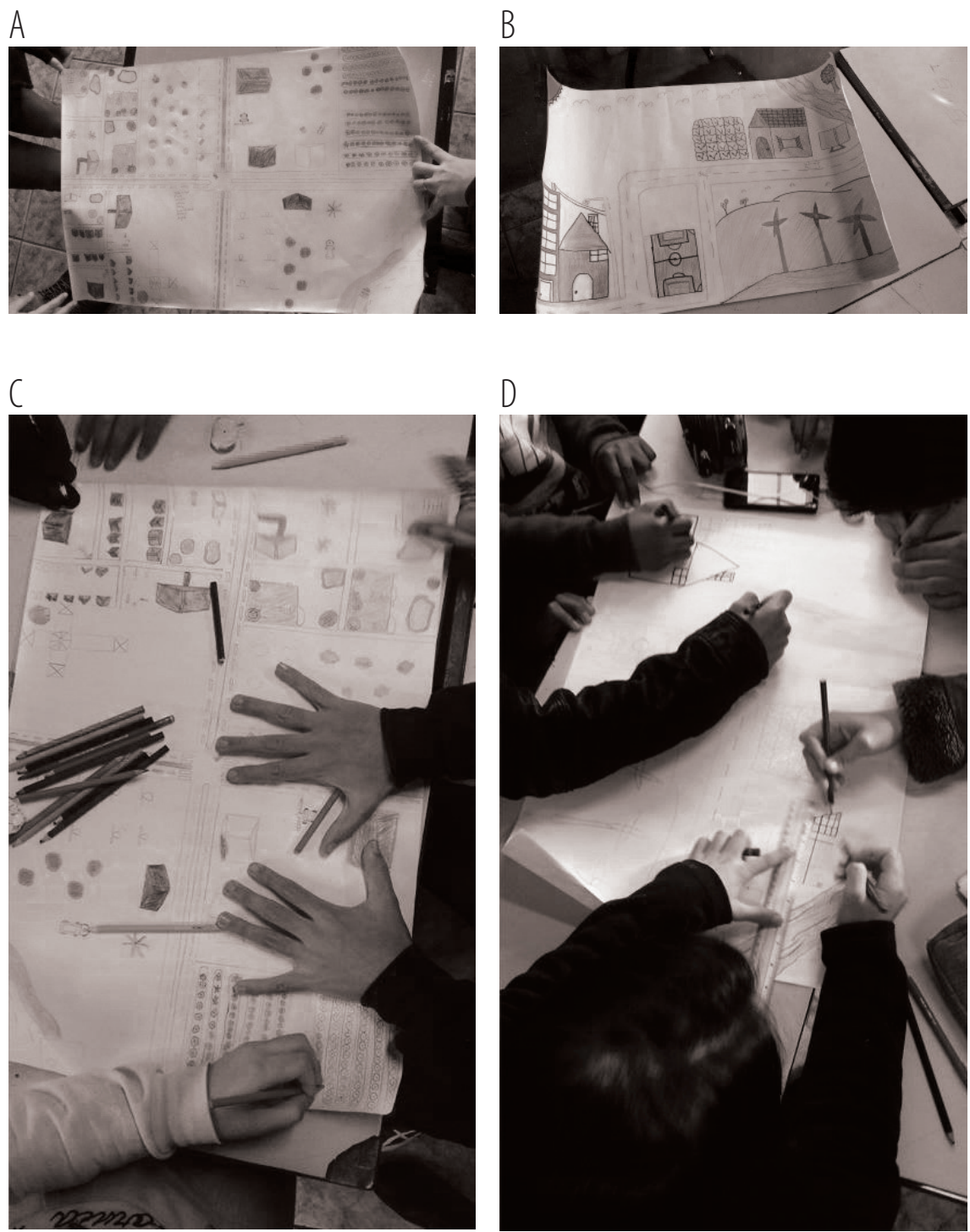

Fonte: Arquivo do PIBID/Geografia/UFSM, em 2017. 
A confecção de cidades sustentáveis foi realizada com os educandos do 7. ${ }^{\circ}$ ano do Ensino Fundamental, objetivando mostrar o padrão de consumo da sociedade atual, que não é sustentável, bem como gerar nos educandos o senso de coletividade e atenção com o ambiente em que vivem.

Os mapas sobre os climas do Brasil foram realizados pelos educandos do 3. ${ }^{\circ}$ ano do Ensino Médio e ilustram a diversidade climática existente no país, sua área de abrangência e características. Tais questões estiveram sempre relacionadas com o tipo de clima no qual o educando está inserido. $\mathrm{Na}$ figura 5, demonstramos, na parte A e B, a confecção de mapas de climas do Brasil por educandos do $3 .^{\circ}$ ano do Ensino Médio, em 2017; nas imagens C e $\mathrm{D}$, a confecção de mapas de refugiados no Brasil, no mesmo ano.

Figura 5: Atividade do PIBID/Geografia/UFSM, em 2017
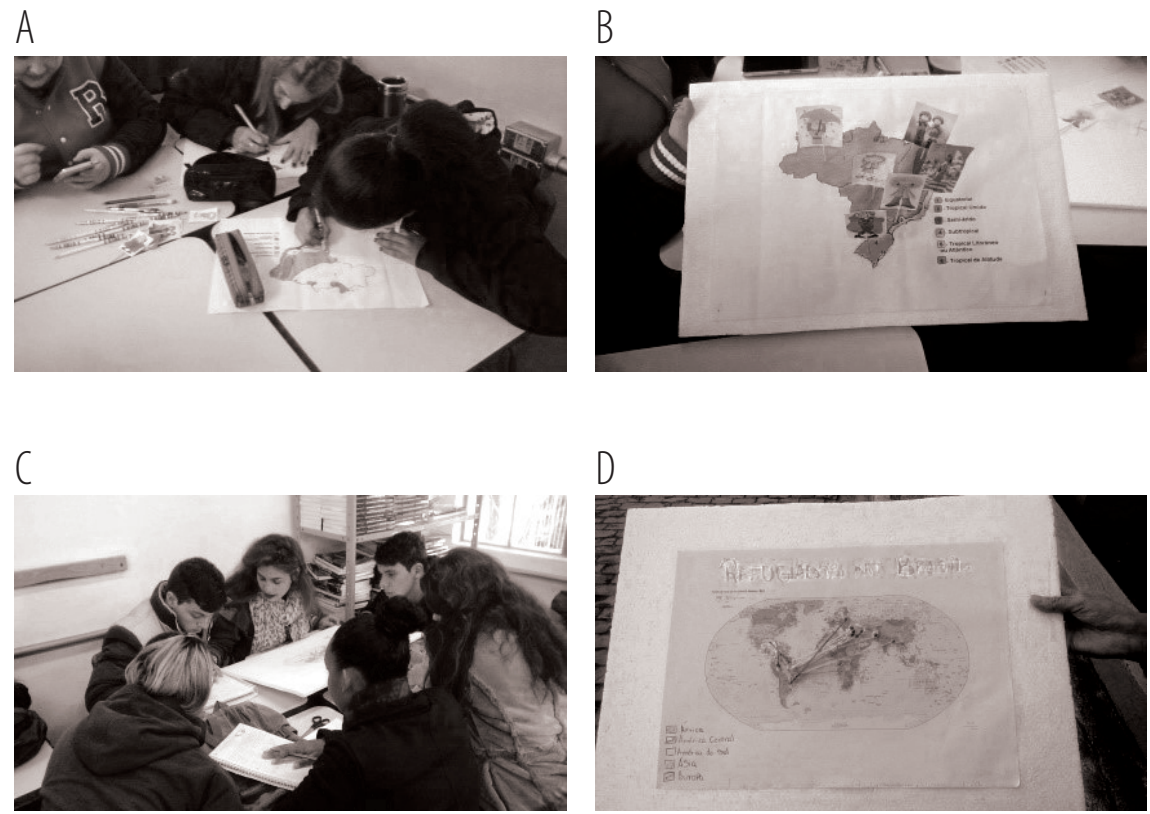

Fonte: Arquivo do PIBID/Geografia/UFSM, em 2017. 
O estudo do processo migratório contemplou a confecção de mapa sobre os refugiados no Brasil, no qual estabeleceram os fluxos existentes tanto para o movimento de imigração como para o de emigração. Isso posto, os educandos foram capazes de criar mecanismos por meio dos quais puderam desenvolver comparações entre o fenômeno mundo x Brasil, tão importante para a compreensão do referido caso.

\section{Desdobramentos da ação do Programa PIBID junto aos antigos acadêmicos do curso de Licenciatura em Geografia da UFSM}

A fim de evidenciar a importância o PIBID também como política pública para a formação docente dos acadêmicos do curso de Licenciatura em Geografia da UFSM, elaborou-se questionário para os antigos bolsistas ${ }^{1}$ do programa. Do total de vinte bolsistas que passaram pelo programa, 13 responderam aos questionários, cujas indagações versaram sobre o tempo de participação no programa, as experiências e conhecimentos da prática pedagógica antes do programa, a importância do PIBID na sua formação, a atuação do bolsista após a participação no programa e a importância do programa para o curso de Licenciatura Plena em Geografia da UFSM.

Em relação à primeira indagação, observa-se, na figura 6, que 54\% dos bolsistas participaram até dois anos no programa, tempo esse estipulado pela Capes, em 2011, como máximo aos alunos de Iniciação à Docência (BID). Participaram por três anos do programa 23\% dos bolsistas, tempo possível porque que não havia limite de participação, e 23\% participaram por um ano, visto que já estavam em fase de finalização do curso de Licenciatura, o que inviabilizou um período maior de inserção junto ao programa.

\footnotetext{
${ }^{1}$ Optou-se somente pelos acadêmicos que já encerraram a participação no programa, em função de serem conhecedores de sua metodologia e de como tal programa contribuiu para sua formação docente.
} 
Figura 6: Tempo de participação dos bolsistas no programa do PIBID/Geografia/UFSM

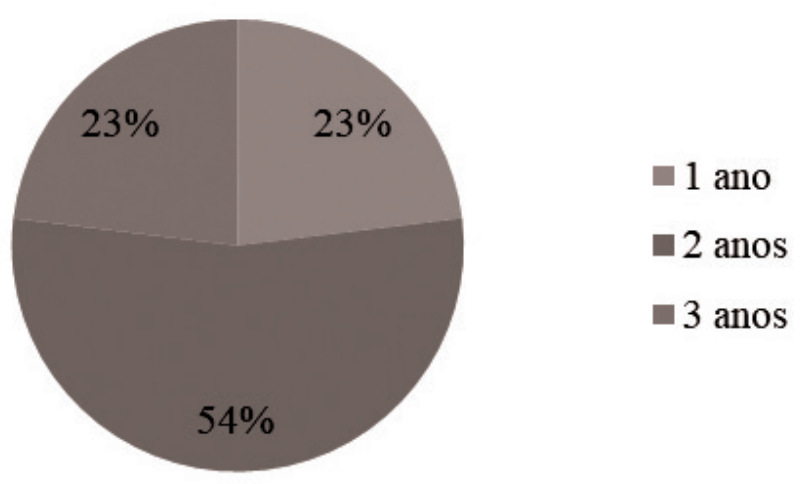

Fonte: Arquivo do PIBID/Geografia/UFSM, em 2017.

Tanto no tempo que foi estipulado pela instituição mantenedora, como no tempo hábil de condição, fica evidente que os bolsistas participaram o máximo permitido pela instituição. Assim, observa-se o interesse dos bolsistas no programa, revelado pelos seus crescentes desenvolvimentos frente à prática pedagógica, bem como pela participação máxima permitida, obedecendo à condição de cada um.

Ao dissertarem sobre os conhecimentos prévios da prática pedagógica antes do programa, fica evidente em todas as falas que não possuíam nenhuma experiência prática na escola. Apenas três bolsistas manifestaram experiência em cursinhos pré-vestibulares ofertados pela própria universidade. Entretanto, ressaltaram que essa experiência é muito diferente da vivenciada na escola pública. Por conseguinte, a maioria, cerca de $76,9 \%$, ressalta que o conhecimento se dava apenas pela teoria contemplada nas disciplinas voltadas à educação ou pela busca individual, por meio de livros que abordam o tema.

Tal preposição mostra que o modo como estão organizados os programas de licenciatura no Brasil, de maneira geral, prioriza o conhecimento teórico em detrimento da prática pedagógica, a qual ocorre apenas no estágio supervisionado, levando o acadêmico a um despreparo quanto à realidade complexa da escola, contribuindo para os altos índices de abandono dos cursos de licenciatura no país. Em função disso, enquanto programa focado na licen- 
ciatura e nas práticas pedagógicas, o PIBID é muito importante na formação docente e na valorização dos cursos de licenciatura como um todo.

No que se refere à importância do PIBID na formação docente dos bolsistas, inferiu-se que o programa possibilitou a aproximação da teoria e da prática, sendo importante para a definição e entendimento do ser professor, proporcionando aprendizados, desde como lecionar, elaborar planos de aula, organizar determinada atividade ou a postura em sala de aula, até enfrentar a realidade complexa escolar, compreender as diferenças entre os níveis de ensino e diferenças de aprendizagens; além disso, contribuiu para o conhecimento da importância da produção acadêmica mediante a produção de trabalhos para apresentação em eventos da área em estudo e também na definição do ensino de Geografia como área de pesquisa e atuação, conforme evidenciado nas seguintes falas:

O PIBID foi fundamental, uma vez que antecipa a experiência docente dentro da academia, que naturalmente ocorre no último ano da graduação. A possibilidade de tempo de planejamento, discussão, elaboração de recursos didáticos, de ações dentro da escola, de reflexão com os colegas bolsistas foram fundamentais para o meu atual exercício docente. Somam-se a esses fatores, ainda, as leituras estimulantes propiciadas por nossa orientadora, que ainda repercutem na nossa sala (Bolsista, 2011-2014).

Foi a partir dele que defini o ensino de Geografia como campo de pesquisa para minha formação continuada e nele tive a certeza que os desafios com a educação são muitos, mas que acertei em definir a educação como campo profissional (Bolsista, 2011-2013).

Os depoimentos revelam que o PIBID ultrapassa seu principal objetivo, que é a inserção dos alunos no contexto escolar, à medida que rompe com os "muros" da escola/universidade e que instiga o aluno a continuar os estudos buscando uma formação para além da graduação. Aproxima os futuros pesquisadores do ensino enquanto campo profissional que, nos últimos anos, vem perdendo interesse em todas as áreas do conhecimento devido à desvalorização da educação no Brasil. Portanto, o programa possibilita o fomento da permanência dos acadêmicos nos cursos de licenciatura e corrobora para que permaneçam nesse campo de pesquisa. 
Outro aspecto que reforça a importância do PIBID para as licenciaturas, em especial a Geografia, é que a maioria dos seus antigos bolsistas está inserida no mercado de trabalho e continua se especializando por meio dos cursos de pós-graduação (figura 7), cujo percentual é de 38\% do total. Os antigos bolsistas, que atuam como professores da educação básica, correspondem a 23\%; os que estão dando sequência aos estudos mediante nos cursos de pós-graduação somam 15\%; os antigos bolsistas que ainda estão se graduando e que estão se preparando para a seleção de pós-graduação e os que atuam em outra área correspondem a $8 \%$ cada um. Dessa maneira, observa-se que apenas uma pequena parcela dos antigos bolsistas não trabalha na área, mostrando ser o programa motivador tanto na formação docente como na preparação e incentivo para que os alunos deem continuidade aos estudos, contribuindo, assim, para sua permanência na Geografia.

Figura 7: Área de atuação dos antigos bolsistas do programa do PIBID/Geografia/UFSM, em 2017

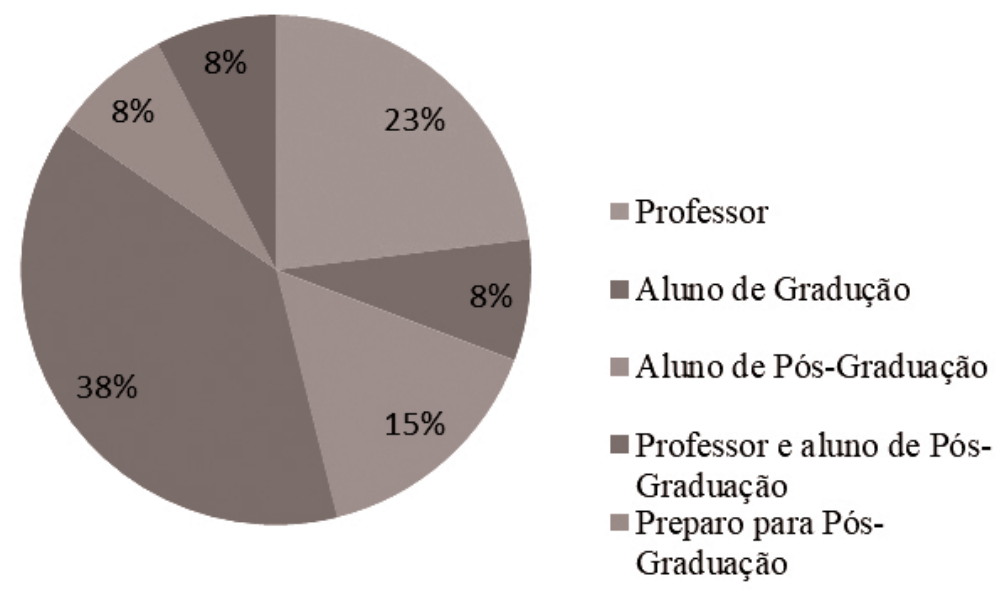

Fonte: Arquivo do PIBID/Geografia/UFSM, em 2017.

Em relação à importância do programa para o curso de Licenciatura Plena em Geografia, foram unânimes em concordar com o importante papel que o programa desempenha junto ao curso, assim como para as demais licenciaturas, conforme mostra o seguinte depoimento: 
O projeto possui enorme relevância para o curso de Licenciatura em Geografia, assim como para os demais cursos de licenciatura. É um projeto que se propõe a experienciar contatos entre futuros professores e a educação básica, proporcionando a prática pedagógica. Acredito que as atividades realizadas trazem experiências benéficas para o discente em fase de formação e o preparam para assumir com responsabilidade seu papel na sociedade (Bolsista, 2014-2016).

Reforçando a amplitude do programa, foram destacados alguns pontos, sendo por intermédio dele que os acadêmicos têm sua primeira inserção na escola, cuja experiência em sala de aula possibilita a pesquisa fundamental na prática docente, promove discussão de anseios e possibilidades com outros licenciados, contribuindo para que se conheça a futura profissão, sanando qualquer dúvida sobre o assunto. A maioria dos antigos bolsistas concorda ser o programa tão relevante que deveria contemplar automaticamente todos os acadêmicos da licenciatura do curso de Geografia.

Além disso, reforçam que o referido programa gerencia a interação escola/universidade, cuja contribuição para uma educação básica de qualidade é notória ao formar educandos conscientes de seu papel transformador na sociedade.

\section{Considerações finais}

O PIBID/Geografia tem representado um espaço de interlocução, de amadurecimento dos estudos educacionais e de solidificação de estudos sobre o cotidiano dos educandos. As reunióes são pontos de encontro de experiência, saberes, dúvidas e conhecimentos, tempo para refletir e discutir a prática pedagógica. Além do conhecimento tecido ao longo do programa, o PIBID/Geografia permite conhecer algumas dinâmicas do âmbito acadêmico e da escola básica, pesquisas que preparam os bolsistas para estudo e experiência docente posteriores. A história desse programa para a melhoria dos cursos de licenciatura evidencia, na fala dos antigos acadêmicos participantes, estrutura pertinente e fundamental para o exercício e aprimoramento da atividade docente, a qual deve estar inserida nos primeiros anos do curso acadêmico. 
A forma como os acadêmicos de graduação se referem aos conhecimentos a eles conferidos indica a possibilidade de integração entre os saberes aprendidos na academia e os saberes aprendidos na escola, apontando a relevância desse programa no âmbito da formação de professores.

\section{Referências}

ALMEIDA, R. D. de. (org.). Do desenho ao mapa: iniciação cartográfica na escola. São Paulo: Contexto, 2001.

CALLAI, H. C. A formação do profissional da geografia: o professor. Ijuí: Editora UNIJUÍ, 2013.

FREIRE, P. Pedagogia do oprimido. São Paulo: Paz e Terra, 1972.

LOCH, R. E. N. “Cartografia tátil: mapas para deficientes visuais”. Portal da Cartografia, v.1, n. 1, 2008. Disponível em: http://www.uel.br/revistas/ uel/index.php/portalcartografia/index. Acesso em: $1^{\circ}$ set. 2017. 


\section{SOBRE OS AUTORES}

\section{Anercilia Martins}

Graduada em Geografia pela Universidade Federal Fluminense (UFF). Mestre em Geografia pela Universidade do Estado do Rio de Janeiro (UERJ). Tutora do Centro de Educação Superior a Distância do Rio de Janeiro.

\section{Andréia da Silva Mafassioli}

Graduada em Pedagogia pela Faculdade Porto Alegrense(FAPA). Doutora em Educação pela Universidade Federal do Rio Grande do Sul (UFRGS).

\section{Ane Carine Meurer}

Graduada em Pedagogia pela Faculdade de Filosofia, Ciências e Letras Dom Bosco. Doutora em Educação pela Universidade Federal da Bahia (2003). Professora da Universidade Federal de Santa Maria (UFSM).

\section{Carmen Rejane Flores Wizniewsky}

Graduada em Geografia pela Universidade Federal de Santa Maria (UFSM). Doutora em Geografia pela Universidade de Córdoba - Espanha. Professora do Departamento de Geografia da UFSM. 


\section{Cesar De David}

Graduado em Geografia pela Universidade Federal de Santa Maria (UFSM). Doutor em Geografia pela Universidade Federal de Santa Catarina (UFSC). Professor do Departamento de Geografia da UFSM.

\section{Cintia Moralles Camillo}

Graduada em Matemática pela Universidade Federal do Rio Grande (FURG). Especialista em Estatística e Modelagem Quantitativa pela Universidade Federal de Santa Maria (UFSM).

\section{Claudete dos Santos da Silva}

Graduada em Pedagogia pela Universidade Federal de Santa Maria (UFSM). Especialista em Gestão Educacional pela UFSM. Atua em escolas de Ensino Fundamental.

\section{Daiane Loreto de Vargas}

Graduada no Curso de Tecnologia em Agropecuária: Sistemas de Produção pela Universidade Estadual do Rio Grande do Sul/ UERGS. Mestre em Extensão Rural pela Universidade Federal de Santa Maria/ UFSM. Doutora pelo Programa de Pós-Graduação em Extensão Rural - Universidade Federal de Santa Maria/ UFSM. Ph.D em Geografia na Universidade Federal de Santa Maria.

\section{Dante Luis Vartha}

Graduado em História pela Universidade Federal do Rio Grande do Sul (UFRGS). Mestre em Ensino de História pela UFSM. Professor da educação básica.

\section{Diovane Dill}

Graduado em História pela Universidade do Vale do Rio dos Sinos (UNISINOS). Mestre em ensino de História pela UFSM. Gestor Municipal. 


\section{Dilmar Luiz Lopes}

Graduado em Filosofia pela Universidade Franciscana. Doutor em Educação pela UFRGS. Professor da Faculdade de Educação da UFRGS.

\section{Douglas Cenci}

Graduado em Administração pela Universidade Norte do Paraná (UNOPAR). Especialista em Agricultura Familiar pela UFFS.

\section{Edimar Rodrigo Rossetto}

Graduado em Geografia pela Universidade Estadual do Oeste do Paraná. Mestre em Geografia pela mesma instituição. Professor da Rede Municipal de Educação.

\section{Eliane Boroponepá Monzilar}

Graduada em Ciências Sociais pela Universidade do Estado de Mato Grosso (UNEMAT). Mestre em Desenvolvimento Sustentável pela Universidade de Brasília, (UnB). Doutoranda em Antropologia pela UnB, professora de Educação Básica.

\section{Francisca Edilza B. A. Carvalho}

Licenciada em Pedagogia pelo ITEC. Mestre em Educação pela UFMT. Docente da Educação Básica no Mato Grosso.

\section{Gabriela Dambrós}

Graduada em Geografia - Licenciatura (UFSM). Mestra em Geografia (UFSM). Doutora em Geografia (UFRGS). Professora da Rede Pública Municipal de Gravataí/RS. 


\section{Glaucio José Marafon}

Graduado em Geografia pela Universidade de Passo Fundo (UPF). Doutor em Geografia pela Universidade Federal do Rio de Janeiro (UFRJ). Professor da Universidade do Estado do Rio de Janeiro (UERJ).

\section{Gilda Maria Cabral Benaduce}

Graduada em Geografia pela Universidade Federal de Santa Maria (UFSM). Doutora em Geografia pela Universidade Estadual Paulista Julio de Mesquita Filho (UNESP). Professora do Departamento de Geografia da UFSM.

\section{Hellen Cristina de Souza}

Licenciada em Pedagogia pela UCDB. Doutora em Ciências Sociais pela PUC-SP. Professora formadora do Cefapro-MT.

\section{Idiane Manica Radaelli}

Graduada em Administração pela Universidade Estadual do Rio Grande do Sul (UERGS). Mestre em Desenvolvimento pela Universidade do Noroeste do Rio Grande do Sul (UNIJUÍ). Doutoranda em Ciências Sociais pela Universidade do Vale dos Sinos (UNISINOS). Professora da Universidade do Oeste de Santa Catarina (UNOESC).

\section{Ivanio Folmer}

Graduado pela Universidade Federal de Santa Maria no curso de Geografia. Mestre em Geografia pelo Programa de Pós-graduação em Geografia-PPGGEO/UFSM. Doutorando em Geografia-PPGGEO/UFSM.

\section{Janete Webler Cancelier}

Graduada em Geografia pela Universidade Comunitária da Região de Chapecó (UNOCHAPECÓ). Doutora em Geografia pela Universidade Federal de Santa Maria (UFSM). 


\section{José Iran Ribeiro}

Graduado em História pela Universidade Federal de Santa Maria (UFSM). Doutor em História Social pela Universidade Federal do Rio de Janeiro (UFRJ). Professor da UFSM.

\section{José Amilcar Bertholini de Castro}

Graduado em História. Especialista em Gestão Pública. Mestre e doutorando em história. Técnico administrativo da UFMT.

\section{Lair Miguel da Silva}

Graduado em Geografia pela Universidade Federal de Uberlândia (UFU). Mestre em Geografia pela UFU. Professor do Ensino Fundamental.

\section{Leonice Alves Pereira Mourad}

Licenciada em História pela UNISINOS. Doutora em História pela UNISINOS. Professora adjunta da UFSM.

\section{Lisane Regina Vidal Conceição}

Graduada em Geografia pela Universidade Federal de Santa Maria (UFSM). Mestre em Geografia da UFSM. Doutora em Geografia pela UFSM. Professora da Rede Estadual do estado do Rio Grande do Sul e da Rede municipal de Santa Maria.

\section{Liziany Müller Medeiros}

Graduada em Zootecnia pela Universidade Federal de Santa Maria (UFSM). Doutora em Agronomia pela UFSM. Professora do Departamento de Educação Agrícola e Extensão Rural (CCR/UFSM). 


\section{Luis Pedro Hillesheim}

Graduado em Administração Rural pela Faculdades Reunidas de Administração, Ciências Contábeis e Econômicas (FACEPAL). Mestrado em Ciências Sociais Aplicadas pelo Centro Universitário Diocesano do Sudoeste do Paraná. Professor da Escola de Ensino Médio Casa Familiar Rural.

\section{Luciana de Aguilar Belizio}

Graduada em Turismo pela UNIFRA e graduanda em ciências sociais pela UFSM. Mestre em Patrimônio Cultural pela UFSM.

\section{Marcelo Cervo Chelotti}

Graduado em Geografia pela Universidade Federal de Santa Maria (UFSM). Doutorado em Geografia pela Universidade Federal de Uberlândia (UFU). Professor da Universidade Federal de Uberlândia.

\section{Maria Helena Tavares Dias}

Graduada em Pedagogia pela Universidade do Estado do Mato Grosso (UNEMAT). Mestre em Educação pela UFMT. Docente de educação básica na UFMT.

\section{Maria Auxiliadora de Azevedo Coutinho e Castro}

Graduada em História e Direito. Mestre e doutoranda em História. Docente da UNEMAT-Cáceres.

\section{Mariane D. Martins}

Bacharel em Administração pela Universidade Estadual do Rio Grande do Sul. Bacharel em Sociologia pela Universidade Regional do Noroeste do Estado do Rio Grande do Sul (UNIJUÍ). Mestre em Educação nas Ciências na mesma universidade. Professora da UNIJUí. 


\section{Maiquel Ivan Rossato}

Graduado em Geografia pela Universidade Federal de Santa Maria (UFSM). Especialista em curso de E.A.F.C e Educação do Campo pela Universidade Federal de Santa Maria (UFSM). Mestrando em Geografia pela UFSM. Professor do Ensino Fundamental.

\section{Marli Terezinha Szumilo Schlosser}

Graduada em Geografia pela Universidade do Oeste Paulista (UNIOESTE). Doutora em Geografia pela Universidade Estadual Paulista Julio de Mesquita Filho (UNESP). Professora em Geografia da Universidade Estadual do Oeste do Paraná.

\section{Marinez Cargnin-Stieler}

Graduada em Matemática pela UFSM. Doutora em Engenharia Elétrica pela UNESP. Professora da Universidade do Estado do Mato Grosso (UNEMAT).

\section{Marcus Vinicius Araújo Damasceno}

Graduado em Física pela Universidade Federal do Piauí. Doutor em Física pela USP. Professor da Universidade do Estado do Mato Grosso (UNEMAT).

\section{Solange de Moura Trindade}

Graduada em Ciências Sociais (UNISINOS). Graduada em Pedagogia (ULBRA). Mestra em Ciências Sociais (UNISINOS). Professora na Educação Básica.

\section{Rogério Vanderlei de Lima Trindade}

Bacharel em Desenho e Plástica pela Universidade Federal de Santa Maria (UFSM). Mestre em Artes - Poéticas Visuais pela Universidade Estadual de Campinas (UNICAMP). Doutor em Educação pela Universidade Federal de Santa Maria (UFSM). 


\section{Tatiane Almeida Netto}

Engenheira Florestal. Mestre em Extensão Rural. Doutora em Geografia no Programa de Pós-graduação em Geografia da Universidade Federal de Santa Maria.

\section{Vanilda Teófilo}

Graduada em Pedagogia pela Universidade Santa Úrsula (USU). Doutora em Educação pela Universidade do Estado do Rio de Janeiro (UERJ). Professora da Fundação Centro de Ciências e Educação Superior à Distância do Estado do Rio de Janeiro.

\section{Zenicleia Angelita Deggerone}

Graduada em Administração pela Universidade Estadual do Rio Grande do Sul (UERGS). Mestre em Ambiente e Desenvolvimento pela Universidade do Vale do Taquari (UNIVATES). Doutoranda em Desenvolvimento Rural pela UFRGS. Professora Titular da Universidade Estadual do Rio Grande do Sul. 
Formato $16 \times 23$

Tipologia: Garamond Premier Pro (texto) Myriad Pro (títulos) Papel: Polén Soft $80 \mathrm{~g} / \mathrm{m}^{2}$ (miolo)

Supremo $250 \mathrm{~g} / \mathrm{m}^{2}$ (capa)

CTP, impressão e acabamento: Print Mais Gráfica e Editora LTDA 